\title{
Market reactions to management earnings forecasts
}

\author{
Citation for published version (APA):
}

Felleg, R. (2015). Market reactions to management earnings forecasts. [Doctoral Thesis, Maastricht University]. Datawyse / Universitaire Pers Maastricht. https://doi.org/10.26481/dis.20150423rf

Document status and date:

Published: 01/01/2015

DOI:

10.26481/dis.20150423rf

Document Version:

Publisher's PDF, also known as Version of record

\section{Please check the document version of this publication:}

- A submitted manuscript is the version of the article upon submission and before peer-review. There can be important differences between the submitted version and the official published version of record.

People interested in the research are advised to contact the author for the final version of the publication, or visit the DOI to the publisher's website.

- The final author version and the galley proof are versions of the publication after peer review.

- The final published version features the final layout of the paper including the volume, issue and page numbers.

Link to publication

\footnotetext{
General rights rights.

- You may freely distribute the URL identifying the publication in the public portal. please follow below link for the End User Agreement:

www.umlib.nl/taverne-license

Take down policy

If you believe that this document breaches copyright please contact us at:

repository@maastrichtuniversity.nl

providing details and we will investigate your claim.
}

Copyright and moral rights for the publications made accessible in the public portal are retained by the authors and/or other copyright owners and it is a condition of accessing publications that users recognise and abide by the legal requirements associated with these

- Users may download and print one copy of any publication from the public portal for the purpose of private study or research.

- You may not further distribute the material or use it for any profit-making activity or commercial gain

If the publication is distributed under the terms of Article $25 \mathrm{fa}$ of the Dutch Copyright Act, indicated by the "Taverne" license above, 
Market Reactions to Management Earnings Forecasts

Réka Felleg 
Datawyse / Universitaire Pers Maastricht ISBN 9789461594310 


\section{Market Reactions to Management Earnings Forecasts}

\section{DISSERTATION}

to obtain the degree of Doctor at the Maastricht University, on the authority of the Rector Magnificus, Prof. Dr. L.L.G. Soete, in accordance with the decision of the Board of Deans, to be defended in public on Thursday, April 23, 2015 at 16.00 hours

by

Réka Felleg

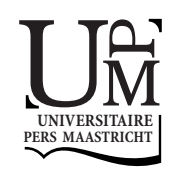


Promoter

Prof. Dr. Frank Moers

Co-Promoter

Dr. Annelies Renders

Assessment Committee

Prof. Dr. Roger Meuwissen (Chair)

Prof. Dr. Martin Carree

Prof. Dr. Erik Peek (Erasmus University, Rotterdam)

Prof. Dr. David Veenman (Erasmus University, Rotterdam) 




\section{Acknowledgements}

Pursuing my doctoral degree has been an adventure. It has had its ups and downs, taken me to places literally, figuratively, and geographically that I have not dreamed of, I have obviously (and/or hopefully) learned a lot academically, but I have also grown in innumerable ways beyond the specific purpose of obtaining my degree. Because this adventure was not a natural progression in my life, following smoothly other stages of my academic journey, and because life has taken me to interesting places and allowed me to get to know interesting people even before taking the first step towards Maastricht, that and who definitely helped me to take that first step, I have a lot of thanks to share. Bear with me!

First and foremost, I would like to thank my promoter and co-promoter. I would like to express my thanks to Professor Dr. Frank Moers (by proxy) for accepting me into the $\mathrm{PhD}$ program at Maastricht University, and (not by proxy) for providing me with both a benchmark and a compass in academia and academic research by way of critical evaluation of ideas, proposals or papers, and more specifically, by demonstrating over and over again, that any complex or complex-sounding idea can be pared down to its bare-bone theoretical architecture and therefore, discussed in simple terms. I would like to thank Annelies Renders, my co-promoter, immediately after Frank, for requesting to work with me as my daily supervisor. I have learned a lot from our academic discussions, but perhaps more importantly, I gained even more from your constant support, both in motivation and morale.

I would like to thank the members of my reading committee, Professor Dr. Roger Meuwissen, the Chair, Professor Dr. Martin Carree, Professor Dr. Erik Peek, and Professor Dr. David Veenman for giving me the opportunity to defend my dissertation by taking the time to evaluate and approve my thesis and (hopefully) examining it and me by asking questions at my public defense.

I would like to thank Gilles Hilary for very many specific things: the multitude of his papers that are exciting and rigorous at the same time; fortifying my confidence in my ability to generate research ideas by writing a paper on a topic that I have written my 
first proposal on (and therefore giving me only half a disappointment that the idea will not be written into a paper by me); the opportunity for the phd visit to INSEAD and therefore access to data that enabled me to write all three of my papers in this thesis; writing requests on my behalf, i.e. giving me access to his vast network of researchers, that resulted in my visit at Nanyang Technological University in Singapore and exposure to courses, researchers, people, culture, and the experiences of a lifetime... But most of all I would like to express my gratitude for being the embodiment of and reinforcing my faith in selflessness and altruism in academia.

I would like to thank Professor Dr. Ann Vanstraalen, and Professor Dr. Tom Groot of the Limperg Foundation, for giving me the financial backing that has made my phd visits possible.

Many thanks to my coauthors, Arpita Shroff and Gerry Lobo. Thank you Arpita for being a friend since that fateful rookie camp in Florida through thick and thin! We surely had our share of difficulties, letdowns, false starts, and problems, but we have (so far) mastered everything our project and circumstances have thrown our way: time differences (let it be $6,7,8,13$ or 14 hours), technological problems, database complexities and econometrics, personal setbacks, and have become better for it. It is high time for the successes! My thanks also go to Gerry Lobo, for generously providing Arpita and me with his time, resources, but also his academic and econometric experience and insights.

My thanks go to Accounting department faculty and staff at the University of Maastricht for providing a constructive learning environment throughout my phd studies, courses, enlightening workshop discussions, providing opportunities for course tutoring, standing in as co-supervisors at master thesis defenses, department days and many other reasons. I would also like to thank my new colleagues at the University of Amsterdam: you are the nicest group of people I know. I have felt welcome from even before my first working day and this feeling has only gotten stronger since, and of course this has helped me enormously in relocating from Maastricht and starting my new life in Amsterdam, academically and otherwise. 
I thank my fellow phd students in Maastricht: Anant, Abiot, Britt, Christoph, Jeroen, Jonas, Judith, Julius, Lars and Lars, Mona, Patrick, Ronny (and Isabell), and Thomas, most of whom I have shared an office with for a shorter or longer period of time, during my office hopping adventures. I thank you for teaching me about so many areas of accounting and econometrics - I can only attempt to list them all: audit, CDSs, innovations and patents, insider trading, IT disclosures, software obsolescence, propensity score matching, ratcheting. I'd like to thank you most of all for disassembly and assembly parties at my places, and Sunday study parties in the unheated or overly hot phd offices of the empty Tongersestraat 53 building.

My Singapore visit has enriched my life in many ways. I have learned a lot from Bin Ke, Tan Hun-Tong and fellow students in courses at NTU. I have received generous feedback on a proposal from Neil Bhattacharya at Singapore Management University. I had an amazing afternoon of discussion on topics from accounting, through literature and religion, to politics with Tharindra Ranashinge. I have spent $12+$ hour days in the phd office and the mensa with all the wonderful finance and accounting phd students. And I have learned a lot from Lukas, a fellow European and UM alumni in Singapore, then and since then. Thank you all!

Christine, Eva, Jan, Kata, Zsombor, and many more people have touched upon my life for shorter or longer periods of time in Maastricht, I thank you for the games and discussions (with or without cider and Lambrusco) in Maastricht and beyond.

My special thanks, and hugs and kisses, go to (former) Maastricht tutors \& co: Anke, Christina, Erwin, Golam, Josh, Miel, Nathalie, Neena, Nick, Suzanne, and Thivya. Coffee or wine (or cider), American, Dutch, Hungarian, Indian, or Italian cuisine, Thanksgiving, housewarming, or New Years' party, you are the perfect company to share it with! Thank you for all the wonderful afternoons and nights on the town! Thank you for our discussions and your constant and unconditional support! Thank you for being my family away from home!

My other set of special thanks go to Bas, Lei, Nadine, and Jörg. Bas, I admire your motivation and determination, and am constantly amazed of your different view of the same things that we are interested in. Good luck pursuing your dream! Lei, you are a 
wonderfully funny and generous person, and you are and will remain my honorary paranymph! Nadine, thank you for sharing an office and taking the sunny side! And thank you especially for the last few months of commiseration and co-support. Problems are easier to bear if shared and your sunny personality and outlook can only improve them anyway! And, and, and, I was/am/will be cheering you on for YOUR defense even if I cannot be there! Jörg, I have learned the most from you during the last few years! Given my desire for a journey of lifelong learning I am grateful that I have met you and have been able to and continue to learn so much from you and through you, and that so many new worlds of knowledge have opened up to me.

I would like to thank all my former colleagues at IBS, but primarily Caroline (Bodóczky), (Polyák) Ildi, (Radvány) Éva, (Rácz) Marci, and (Szepesi) Laci, for helping me grow by way of cooking, learning to teach, teaching, food, commiseration, Erasmus visits, food, challenges, invigilation, food, and unexpected posterior confirmatory feedback.

I would also like to thank my hundreds of students at IBS, UM, and UvA, or elsewhere officially or otherwise. Even if (or when) we butted heads, I have appreciated your dedication, motivation, inquisitiveness and demand for knowledge that has kept me on my toes and challenged me constantly to improve.

I would especially like to thank my former students and current friends who I had the pleasure to work and play with both in Hungary and the Netherlands: Eszter, Nóra, and Gergő. The three of you have provided that day-to-day link to Hungary and the language that I didn't even realize I could do with. Eszter, you have found Maastricht and Maastricht University for me, helped with initial discovery, and not-only-initial apartment hunting, or rather apartment finding. Nóra, my official IBS and unofficial Maastricht student, I will always remember our cooking adventures, and the discoveries of environs close and afar. Gergő, my other unofficial student in Maastricht, you were and are that corner of the world in the wild wide West, that is constant, reliable and eternally supportive. I am the grateful continuous beneficiary of your awareness of, access to and willingness to share resources, physical and online, and our in-depth discussions of very wide-ranging topics, from literature to politics. 
Thank you to my friends! Isro and Ray, you are always available for a quick drink and a quick laugh, so when exactly are you visiting me (in Maastricht)? Eta you always make my day sunnier! In person, or during my very quick Facebook visits, you have always managed to cheer me up with real life or online hugs! You are my champion! Visit me more often!!! Eszter, thank you for being partner and tutor to my discoveries of the Netherlands. Your passion for anything Dutch and my passion for discoveries have meshed wonderfully. I hope the tradition continues for many years to come!

Last but not least, I would like to thank my family for being there for me. I'll always remember our three-continents- or three-countries-skype conversations - we always manage to pull it off! My mom held the fort in Hungary for me all these years but I account for only two of those powers of attorneys! Zsolt, who enjoys Dutch and Belgian beer on my behalf. And my sis, who is a trustworthy ally in venting, and has put her international corporate communication expertise to the best use when reviewing and editing all those emails, documents and ideas for me.

In conclusion, plenty of dragons have made my last few years an amazing adventure worth telling. Thank you! 



\section{Table of Contents}

1. Introduction ............................................................................................................ 1

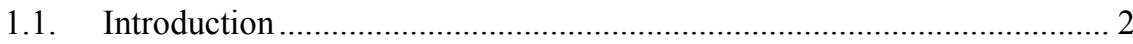

1.2. Disclosure of Accounting Information................................................... 2

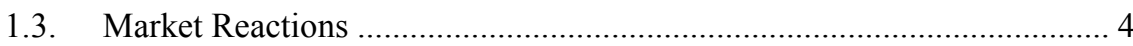

1.4. Management Earnings Forecasts................................................................. 6

1.5. Market Reaction to Higher Earnings Management Incentives Implicit in the Earnings Forecasts of Overoptimistic CEOs ........................................ 8

1.6. The Effect of Management Forecasts on Information Asymmetry Among

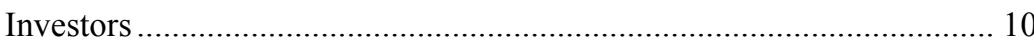

1.7. The Profitability Effect of Small and Large Investors' Differential Trading around Management Forecasts ................................................... 12

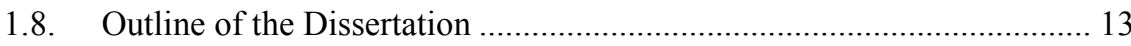

2. Market Reaction to Higher Earnings Management Incentives Implicit in the Earnings Forecasts of Overoptimistic CEOs '................................................... 17

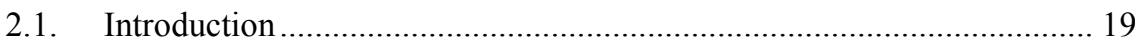

2.2. Prior Research and Hypothesis Development ……………………….... 22

2.2.1. Cognitive Biases and Managerial Decisions ............................ 22

2.2.2. Market Reaction to Biased Forecasts ....................................... 24

2.2.3. Earnings Management Thresholds............................................ 24

2.3. Sample and Empirical Design ............................................................ 27

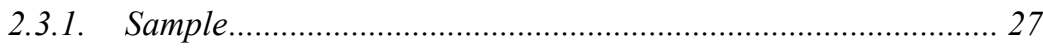

2.3.2. Empirical Design ……………………………….................. 33

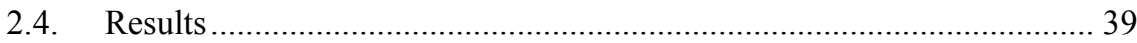




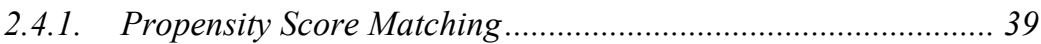

2.4.2. Stage 1-Management Forecast Date ..................................... 40

2.4.3. $\quad$ Stage 2 - Earnings Announcement Date................................. 43

2.4.4. Additional Analyses............................................................ 45

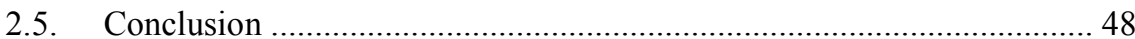

3. The Effect of Management Forecasts on Information Asymmetry Among

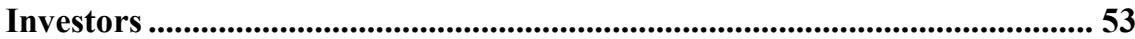

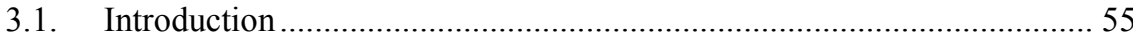

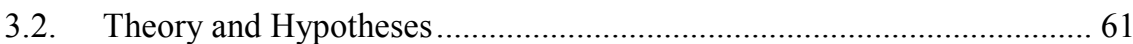

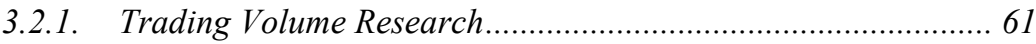

3.2.2. Management Forecasts ..................................................... 63

3.2.3. Hypothesis Development ................................................. 64

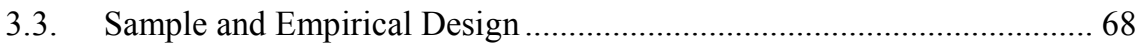

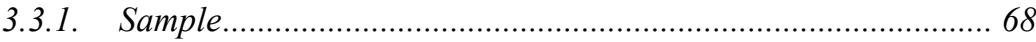

3.3.2. Empirical Design ..................................................................... 71

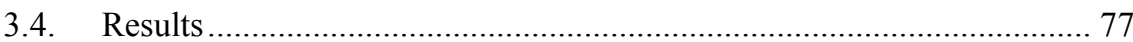

3.4.1. Descriptive Statistics................................................................ 77

3.4.2. Results of Hypothesis Tests ............................................... 82

3.4.3. Additional Analysis - Forecast Specificity............................ 88

3.4.4. Additional Analysis - Effect of Regulation Fair Disclosure ...... 96

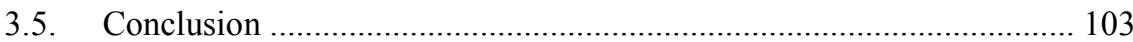

4. The Profitability Effect of Small and Large Investors' Differential Trading around Management Forecasts ' ................................................................... 111

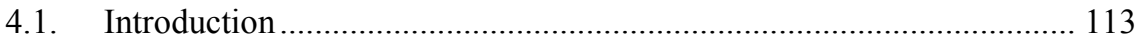

4.2. Motivation and Hypothesis Development .......................................... 119

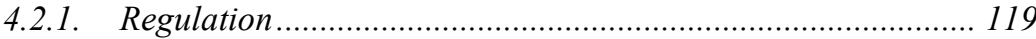

4.2.2. Management Forecasts ...................................................... 121 
4.2.3. Trading Decisions ............................................................ 123

4.2.4. Hypothesis Development ....................................................... 124

4.3. Sample and Empirical Design ....................................................... 129

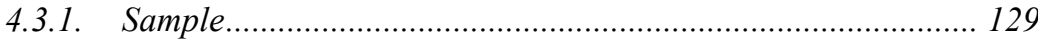

4.3.2. Empirical Design ............................................................ 132

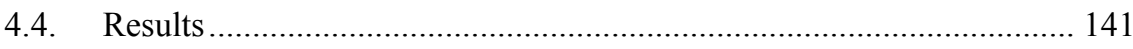

4.4.1. Descriptive Statistics......................................................... 141

4.4.2. Results of Hypothesis Tests .................................................. 162

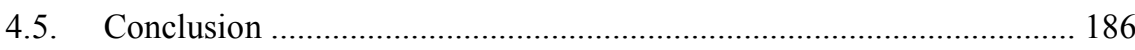

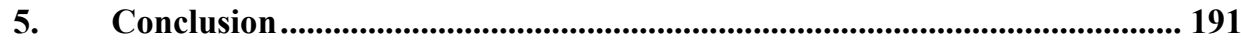

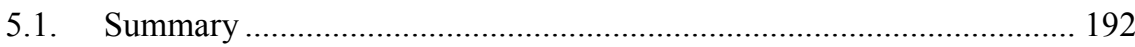

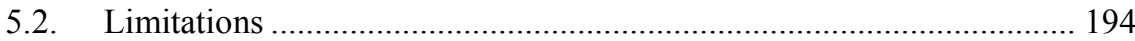

5.3. Contributions and Implications ..................................................... 194

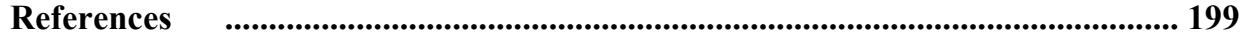

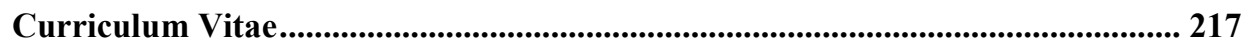



CHAPTER 1

Introduction

\section{Introduction}




\section{CHAPTER 1}

\subsection{Introduction}

The efficient allocation of resources is essential for the optimal functioning of capital market economies. The efficient allocation of funds, however, is hindered by information asymmetry and agency problems: investors have less information than managers, and the incentives of self-interested managers are to expropriate investors. The disclosure of private information by managers to investors is a potential solution to mitigating these problems, because it helps investors ex-ante to assess the profitability of investment opportunities, and ex-post to monitor the use of their investment.

\subsection{Disclosure of Accounting Information}

Accounting theory, specifically the revelation principle, suggests that under the right conditions firms fully disclose their private information (Grossman and Hart, 1980; Grossman, 1981; Milgrom, 1981). Without information about firm profitability, investors are unable to differentiate between good and bad firms, therefore their valuation of every firm equals the average of good and bad firms' values. Good firms then have an incentive to disclose private information about their above average value, leading to a lower average value of the remaining firms. This in turn motivates disclosures by firms with values above the new average, and so forth. Eventually all firms but the worst disclose their true values, thereby the value of the worst firm is also revealed, hence full disclosure is achieved. However, in real capital markets full unraveling is generally not realized, because some of the simplifying assumptions of the theory (e.g., disclosure of private information is costless, verification of information is costless, investors know that firms have private information) are violated. Firms will trade off the costs and benefits of voluntary disclosure leading to an "efficient" level of information disclosure.

It is suggested that desirable levels of disclosure can be achieved by regulation (mandating disclosure) if contracts (providing incentives for disclosure to managers) are not optimal. In case of market failure (market imperfections or externalities) mandatory disclosure may ensure a "socially desirable" level of information in the market (Healy 


\section{CHAPTER 1 \\ Introduction}

and Palepu, 2001, Dye, 2001; Leuz and Wysocki, 2008; Beyer et al., 2010). For example, free-riding on information by potential investors, implicitly paid for by existing investors, may lead to inefficiently low levels of information disclosure. Therefore, viewing accounting information as a public good may justify regulation. Alternatively, concern for the welfare of unsophisticated investors may explain regulation (and redistribute wealth in the economy), because mandatory disclosures may reduce the information asymmetry between more and less well-informed investors (Healy and Palepu, 2001; Beaver, 1998).

Although the justification of mandatory disclosures is often questioned in prior literature (e.g., Kanodia, 2007; Leuz and Wysocki, 2008), the practice of requiring a minimum level of information disclosure from firms is a worldwide phenomenon. Beyond the legally mandated information disclosure, firms provide information voluntarily if the benefits of voluntary disclosure outweigh its costs. In the U.S. corporate disclosures are mandated by, and the environment for voluntary disclosures is also shaped by the Securities and Exchange Commission (SEC). The SEC's mission includes the maintenance of fair, orderly, and efficient markets (SEC, 2013). Safe harbor regulations aim at encouraging companies to provide voluntary, forward-looking information to investors, by reducing litigation costs. ${ }^{1}$ The more recent Regulation Fair Disclosure (RegFD) (2000) banned the selective disclosure of material information, to prevent the provision of private earnings forecasts to select investor groups and level the playing field for individual investors.

In sum, all public firms in the U.S. provide mandatory disclosures, such as financial statements, footnotes, management discussion and analysis, while some firms also provide voluntary disclosures in addition, such as management forecasts, conference calls, press releases to capital market participants.

\footnotetext{
${ }^{1}$ Safe harbor regulations: 1973: the SEC allows firms to include forward-looking information in their annual reports; 1979: the SEC provides safe harbor to firms issuing forward-looking disclosures to protect them against litigation if the forecasts were made in good faith; 1996: the SEC extends the safe harbor to forecasts that do not materialize.
} 


\section{CHAPTER 1 \\ Introduction}

\subsection{Market Reactions}

All public firms disclose mandatory and possibly voluntary financial information, but it is a question whether these are useful to capital market participants. A large part of accounting research is dedicated to examining whether capital market participants react to information disclosures, i.e. whether they find the disclosed information useful.

Beaver (1968) in his seminal accounting study has examined "The Information Content of Annual Earnings Announcements". He argues that there are two definitions of accounting information in terms of market reactions: price and volume, i.e. a change in the market value of stocks, and a change in investors' portfolio holdings. His intuition is that while price reactions reflect changes in the expectations about firm value of the market as a whole, trading volume reactions reflect investor disagreement about the value of firms.

Although Beaver (1968) has introduced trading volume reactions into accounting research, the majority of market reaction studies in accounting test their expectations based on price changes. This branch of accounting research, called capital markets or value relevance research, studies the relation between accounting information and security prices with the main conclusion that mandatory financial reports provide value relevant information to capital market participants (e.g., Collins and Kothari, 1989; Easton and Zmijewski, 1989).

Compared to value relevance research, there is less research into the causes and effects of trading volume reactions to information disclosures. Trading volume reactions are important both from an economic and a regulatory point of view. There is growing agreement among economics, finance and accounting researchers that trading is a significant economic activity that is caused by investor disagreement, and that it provides the most direct evidence of financial accounting information causing changes in investor expectations and hence investor decisions (Cready and Hurtt, 2002; Bamber et al., 2011). Beaver's (1968) early intuition suggests that trading volume reactions reflect a lack of consensus on the value of firms and give insight into disagreements among investors, including disagreement arising from informational disparity, i.e. information asymmetry. 


\section{CHAPTER 1}

Introduction

This is important because trading volumes have been very high over the last decades in developed financial markets (Hong and Stein, 2007), and there is growing consensus that in addition to information asymmetry between the firm and shareholders increasing firms' cost of capital, information asymmetry among investors also results in higher costs of capital (e.g., Botosan and Plumlee, 2002; Botosan et al., 2004; Barron et al., 2005; Bamber et al. 2011). Furthermore, if high trading volumes are a result of increasing information asymmetry among investors, it may indicate that regulatory measures trying to level the informational playing field have not achieved their goal (Bamber et al., 1999; Barron et al., 2005).

While some of the early analytical and empirical trading volume research has relied on the assumption of investor homogeneity (e.g., Bamber and Cheon, 1995; Kandel and Pearson, 1995; Cready and Hurtt, 2002), another stream of volume research examines the effects of investor heterogeneity, in other words investor sophistication, in capital markets in terms of access to and use of information (e.g., Lev, 1988; O'Brien and Bhushan, 1990; Hand, 1990; Potter, 1992; Kim and Verrecchia, 1994). However, trading volume research necessarily relies on the abstract concept of information asymmetry and the simplifying assumption of only two types of investors, sophisticated and unsophisticated. To be able to analyze differential reactions of different investor groups beyond their average reaction (measured by price changes) and their aggregate reactions (measured by trading volumes), even more recently accounting research has turned to examining investors' trades directly. These studies have used the trading behavior of small and large investors to examine the differential impact of new information on these two broad classes of investors. They document a significant difference in the trading behavior of small and large investors around public disclosures, and conclude that small investors' behavior is based on a naïve interpretation of publicly disclosed information, which is likely to lead to unprofitable trading decisions (e.g., Lee, 1992; Bhattacharya, 2001; Bhattacharya et al., 2007; Malmendier and Shanthikumar, 2007; Mikhail et al., 2007; Miller, 2010; Lawrence 2013). 


\section{CHAPTER 1}

Introduction

\subsection{Management Earnings Forecasts}

Management earnings forecasts are an important form of voluntary disclosure. They are issued by management to provide information about the expected earnings of a firm, and thereby establish or influence market earnings expectations (Healy and Palepu, 2001; Hirst et al., 2008; Beyer et al., 2010). Compared to other (measures of) voluntary disclosures, the advantages of management forecasts are that they can be precisely measured, their timing can be established ex post, and their accuracy can be easily verified by outside investors through actual earnings realizations (Healy and Palepu, 2001).

The importance of management earnings forecasts has steadily increased over the last two decades as a result of regulatory changes (e.g., RegFD), changes in financial markets (information intermediaries, investor mix and sophistication, trading methods), and changes in firms' incentives to voluntarily disclose information (e.g., increased use of earnings benchmarks) (Healy and Palepu, 2001; Beyer et al, 2010). As a consequence, the proportion of forecasting firms has increased from approximately $10 \%$ in the mid1990s to $60-80 \%$ by the end of 2010 (Rogers and Van Buskirk, 2012; King, 2013).

Numerous studies show that management earnings forecasts are value relevant as they are an important source of information to capital market participants. Early accounting capital market studies examine the value relevance of management earnings forecasts and find that they influence stock prices (Patell, 1976; Penman, 1980). Subsequent research examines the effect of forecaster and forecast characteristics on stock prices and find that firms' forecasting reputation, forecast news content, type and time horizon, stand-alone vs bundled nature influence their informativeness (Ajinkya and Gift, 1984; Waymire, 1984; Baginski et al., 1993; Hutton et al., 2003; Baginski et al., 2004; Ng et al., 2006; Hutton and Stocken, 2007; Hirst et al., 2008).

In addition to their effect on stock prices, the economic consequences of management earnings forecasts, in terms of capital market effects, include lower bid-ask spreads, higher stock liquidity, and lower cost of capital. Moreover, management earnings forecasts also influence analysts' forecasts and coverage, and institutional ownership (Baginski and Hassell, 1990; Pownall et al., 1993; Coller and Yohn, 1997; Healy et al., 


\section{CHAPTER 1 \\ Introduction}

1999; Ajinkya et al., 2005). Voluntary disclosures are argued to decrease information asymmetry, causing investors to trust market prices as fair, resulting in more trading, i.e. increased liquidity of the stock. Firms with higher levels of disclosure and as a result lower information risk of forecasting future returns, arguably also have a lower cost of capital (Diamond and Verrecchia, 1991; Kim and Verrecchia, 1994; Verrecchia, 2001). In line with theoretical expectations, empirical research finds that firms issuing management forecasts are associated with a higher information asymmetry, measured by bid-ask spreads, prior to the forecast, but lower information asymmetry following the forecast, compared to non-forecasting firms (Coller and Yohn, 1997). Furthermore, an increase in disclosure levels is associated with increase in prices, and more/better disclosures are associated with higher prices (Healy et al., 1999; Gelb and Zarowin, 2000). Moreover, there is a negative association between cost of capital and the level of voluntary disclosures, analyst rankings of annual report disclosures, and lower information asymmetry (Botosan, 1997; Botosan and Plumlee, 2000; Leuz and Verrecchia, 2000).

Earnings announcements, a mandatory disclosure and the cornerstone of firms' information environment, are mostly preempted by other disclosures (Ball and Brown, 1968; Beaver, 1968; Beaver, 2002). It is likely to be management forecasts that partly, or perhaps mostly, preempt earnings announcements: in an earlier study, the market reaction to unexpected management earnings forecasts is similar to that of unexpected earnings announcements (Pownall and Waymire, 1989). More recently, management earnings forecasts are found to be the source of a large portion of the total information in financial markets, as they contain at least twice the information provided by earnings announcements (Ball and Shivakumar, 2008; Beyer et al., 2010).

While management forecasts and earnings announcements are both corporate public disclosures providing information about a firm's earnings, they are different. Management forecasts are of a voluntary nature, are forward-looking, i.e. they provide timelier information on the expected performance of a firm, and are also unverifiable as a result. In contrast, earnings announcements are mandatory, backward-looking, confirmatory, and have a disciplining aspect relating to prior voluntary disclosures, 


\section{CHAPTER 1}

Introduction

because of their more verifiable nature (Ball and Shivakumar, 2008). While earnings announcements are scheduled events, management forecasts, as voluntary disclosures, are unscheduled but can be anticipated by sophisticated investors (Chae, 2005). Moreover, both a manager's decision to issue a forecast as well as forecast attributes can be influenced by managerial incentives (e.g., to manage market expectations and the cost of equity) and biases (e.g., overconfidence, overoptimism) comparatively more than earnings announcements (Hirst et al., 2008; Bamber et al., 2010; Athanasakou et al., 2011). Regardless of our knowledge about their differences, it is still largely unclear what property of management earnings forecasts make them value relevant over and above earnings announcements (Beyer et al., 2010).

In sum, management forecasts are an important means of communicating private information by managers to capital market participants. Due to their different characteristics they are more informative than earnings announcements but management forecasts are still a largely unexplored form of corporate disclosures compared to earnings announcements.

\subsection{Market Reaction to Higher Earnings Management Incentives Implicit in the Earnings Forecasts of Overoptimistic CEOs}

The first study of this dissertation, which can be found in Chapter 2, examines whether investors recognize and rationally impound into the share price the possible earnings management of overoptimistic CEOs at the time the management forecast is issued, rather than the inferred (actual) earnings management at the announcement of realized earnings.

Recently, great progress has been made in academic research in examining the economic effects of cognitive biases (e.g., Malmendier and Tate, 2005 and 2008; Billett and Qian, 2008; Hilary and Hsu, 2011; Hribar and Yang, 2013). Management decision making research shows that overoptimism and overconfidence are common traits of managers, that these cognitive biases affect their real economic decisions, and that cognitive biases in managerial decisions are in general recognized by the market and impounded into the share price (e.g., Roll, 1986; Malmendier and Tate, 2005; Malmendier 


\section{CHAPTER 1 \\ Introduction}

and Tate, 2008; Hillary and Hsu, 2011; Ben-David et al., 2013). In management forecasting research Hribar and Yang (2013) find that forecasts issued by overoptimistic managers are more optimistic than forecasts issued by the average CEO. Trueman (1986) and Kasznik (1999) argue that management forecasts become an earnings threshold that managers try to meet or beat. Finally, Schrand and Zechman (2012) posit that more optimistic forecasts give additional earnings management incentives to managers to meet or beat their forecast. However, to date there is no empirical evidence that answers the question whether overoptimistic managers are more prone to earnings management or whether investors see through the potential earnings management incentives of overoptimistic managers. This study provides evidence on the second of these two questions, by examining investors' reactions to disclosures of overoptimistic managers.

Based on the findings of earnings management around thresholds research that in the period after 2001 all firms that meet or just beat earnings thresholds are punished by capital markets (e.g., Bartov et al., 2002; Kasznik and McNichols, 2002; Skinner and Sloan, 2002; Keung et al., 2010), it is posited that investors recognize not only managerial overoptimism, but also the higher earnings management incentives of overoptimistic CEOs and that they take these incentives into account as soon as they are revealed, which is at the management forecast date.

This hypothesis is investigated by focusing on the earnings announcement date in addition to the management forecast date for two reasons. First, an underreaction to forecasts issued by overoptimistic managers could be explained by the lower credibility of biased forecasts rather than by the earnings management incentives. The underreaction at the forecast date is thus a necessary but not sufficient condition to support the expectation. Second, if investors react to earnings management by overoptimistic CEOs only at the earnings announcement date, the market reaction to earnings of overoptimistic CEOs should not be different from that of an average firm. The market reaction to the earnings of overoptimistic CEOs will only be different if increased earnings management incentives of overoptimistic managers have already been incorporated into the share price at the forecast date. Thus, the earnings announcement date provides a powerful setting to 


\section{CHAPTER 1 \\ Introduction}

test the predictions regarding the market reaction to earnings management incentives of overoptimistic CEOs.

Using a measure of overoptimism based on the percentage of the intrinsic value of unexercised exercisable options to the value of total equity holdings of the CEO at the beginning of the year, it is first confirmed that investors underreact to management forecasts of overoptimistic managers when the forecast is issued. It is shown subsequently that the market reacts more positively to the earnings announcements of overoptimistic CEOs in the small forecast error range compared to those of non-optimistic managers. This implies that at least part of the negative reaction at the forecast date is driven by the market impounding the earnings management incentives of overoptimistic managers. As a consequence, investors do not react to the inferred earnings management of these CEOs at the earnings announcement date in case of small positive forecast errors. In addition, investors react more positively to the perceived lack of earnings management by overoptimistic CEOs compared to non-optimistic managers at the earnings announcement date in case of small negative forecast errors.

\subsection{The Effect of Management Forecasts on Information Asymmetry Among Investors}

The second study of this dissertation, which can be found in Chapter 3, examines the effect of voluntary management earnings forecasts on the information asymmetry among investors around public disclosures. This research question is motivated by the growing significance of information asymmetry among investors and the increasing importance of management forecasts to capital market participants. Traditionally, research has focused on the information asymmetry between the firm and its shareholders and has shown that more (voluntary) disclosure reduces valuation problems by decreasing the information asymmetry between the firm and its investors (Healy and Palepu, 1993; Bamber et al., 2011). In addition to the increasing regulatory concern, however, there is growing evidence that the information asymmetry among investors may also adversely affect a firm's cost of capital (e.g., Botosan and Plumlee, 2002; Botosan et al., 2004; Barron et 


\section{CHAPTER 1 \\ Introduction}

al., 2005). Although the characteristics of voluntary disclosures suggest that they may be associated with differential information asymmetry among investors compared to mandatory disclosures, empirical research has almost exclusively examined information asymmetry among investors around earnings announcements. Hence, empirical evidence relating to the effect of voluntary disclosures on information asymmetry among investors is scant.

This study therefore examines the incremental effect of management earnings forecasts on the information asymmetry among investors. Using the trading volume theory of Kim and Verrecchia (1997), the trading volume effects of pre-announcement private information and event-period private information are differentiated using the same regression model. Furthermore, to be able to isolate the effects of management forecasts, the unbundled public disclosures of a matched sample of forecasting and non-forecasting firms are used. First the trading volume effects of management forecasts are compared with those of earnings announcements of non-forecasting firms. Then the trading volume induced by the earnings announcement of forecasting and non-forecasting firms is compared. This method allows the examination of (1) the incremental trading volume effects of management earnings forecasts at the management forecast date, and (2) the effect of management forecasts on the trading volume around the subsequent earnings announcement.

First, the study finds that, in isolation, voluntary management forecasts generate higher information asymmetry among investors than mandatory earnings announcements. Next, the study finds that earnings announcements of forecasting firms are associated with lower information asymmetry among investors than earnings announcements of nonforecasters. Aggregating the trading volume effects of management forecasts from around the forecast issue and the subsequent earnings announcement, the study concludes that investors of forecasting firms face a larger overall information asymmetry than investors of non-forecasting firms as a result of the event-period information component. Taking into account the volume effects at both the forecast and earnings announcement date, the aggregate information asymmetry associated with pre-announcement information is not different between forecasting and non-forecasting firms, because the higher trading 


\section{CHAPTER 1}

Introduction

volume reaction for forecasters at the forecast date is fully compensated by a lower trading volume at the earnings announcement date. In contrast, the aggregate information asymmetry associated with event-period information is higher for forecasters compared to non-forecasters because the information asymmetry generated by forecasting firms' earnings announcement is not different from that of non-forecasting firms, and hence the higher trading volume reaction at the management forecast date is not compensated by a lower trading volume reaction at the earnings announcement.

Overall these findings suggest that rather than leveling the informational playing field among investors, the voluntary disclosure of management forecasts contributes to increasing the informational disadvantage of some investors over others. Furthermore, while more voluntary disclosure may decrease information asymmetry between the firm and its investors as a whole, it may have unintended consequences by increasing the information asymmetry among investors and thus weakening the disclosure's positive effects on the firm's cost of capital.

\subsection{The Profitability Effect of Small and Large Investors' Differential Trading around Management Forecasts}

Motivated by regulatory interest as well as the importance of management forecasts, the third study of this dissertation, which can be found in Chapter 4, examines how different investor classes utilize management earnings forecasts, and the economic consequences of small (naïve) investors' trading decisions compared to those of large (sophisticated) investors around management forecasts, using earnings announcements as a benchmark. Specifically, relying on the trading behavior of small and large investors to examine the differential impact of new information on these two broad classes of investors, the study examines i) whether management forecasts affect the trading behavior of different investor groups at the management forecast date differentially compared to the earnings announcement, and more practically, ii) whether the difference in profitability of small and large investors' trades changes at the management forecast compared to the earnings announcement dates. 


\section{CHAPTER 1}

Introduction

The study finds that the trading behavior of small and large investors at the management forecast date is different compared to that around the earnings announcement, and the difference in their trading behavior differs at the management forecast compared to earnings announcements. Furthermore, management forecasts influence the trading behavior of small and large investors differentially, because small investors trade in the direction of a random walk forecast error around the management forecast but not around earnings announcements, in contrast with large investors, whose trades are not associated with forecast errors around corporate announcements.

In addressing the main question of differential trading profitability of investor groups around management forecasts and earnings announcements, the study finds that the difference in profitability between small and large investors' trades is different between earnings announcements and management forecasts. Specifically, small investors lose significantly more on trades around non-forecasting firms' earnings announcements, and they gain significantly more on trades around management forecasts. In sum, compared to earnings announcements management forecasts improve the profitability difference of small investors' trades compared to large investors by reversing a differential loss at the earnings announcement into a differential profit at the management forecast. Examining, in addition, if firm characteristics or the characteristics of the management forecast affect the profitability differential of small investors' trades, the study finds that firm and forecast characteristics on average, do not help small investors to improve their profitability differential at management forecasts compared to earnings announcements.

\subsection{Outline of the Dissertation}

Each of the following three chapters describes one of the three aforementioned studies in this dissertation in detail. As the studies are largely independent from one another, they can be read separately or in different order than presented in this book. Chapter 2 presents the study on the market reaction to higher earnings management incentives implicit in the earnings forecasts of overoptimistic CEOs. Chapter 3 focuses on the effect of 


\section{CHAPTER 1}

Introduction

management forecasts on the information asymmetry among investors. Chapter 4 shows the analysis of the profitability effect of small and large investors' differential trading around earnings announcements and management forecasts. Chapter 5 summarizes the main findings of the three studies, discusses their limitations, and their contributions and implications. 




\section{Market Reaction to Higher Earnings Management Incentives Implicit in the Earnings Forecasts of Overoptimistic CEOs ${ }^{2,3}$}

\footnotetext{
${ }^{2}$ This chapter is based on a working paper co-authored with Frank Moers and Annelies Renders. ${ }^{3}$ I am grateful to Gilles Hilary at INSEAD, for a visiting scholarship. I appreciate comments by Thomas Keusch, Frank Schiemann, Ann Vanstraelen, workshop participants at Maastricht University and the Summer Workshop of the Institute of Economics of the Hungarian Academy of Sciences, and participants of the 2012 and 2013 IAAER conferences.
} 


\begin{abstract}
We examine whether investors recognize and rationally impound into the share price the possible earnings management of overoptimistic CEOs at the time the management forecast is issued, rather than the inferred (actual) earnings management at the announcement of realized earnings. We first confirm that investors underreact to management earnings forecasts issued by overoptimistic managers. Next we find that the market reacts more positively to the earnings announcements of overoptimistic CEOs when realized earnings are slightly above or below forecasted earnings compared to those of non-optimistic managers. This confirms our expectations that investors react negatively to the higher earnings management incentives of overoptimistic managers when the forecast is issued and not to actual earnings management when earnings are announced.
\end{abstract}




\section{CHAPTER 2 \\ Market Reaction to Higher Earnings Management Incentives Implicit in the Earnings Forecasts of Overoptimistic CEOs}

\subsection{Introduction}

We examine whether investors recognize and rationally impound into the share price the possible earnings management of overoptimistic CEOs at the time the management forecast is issued, rather than to the inferred (actual) earnings management at the announcement of realized earnings. Our question is motivated by the following findings of previous literature: (1) Hribar and Yang (2011) find that forecasts issued by overoptimistic managers are more optimistic than forecasts issued by the average CEO; (2) Trueman (1986) and Kasznik (1999) argue that management forecasts become an earnings threshold that managers try to meet or beat, and Schrand and Zechman (2011) posit that more optimistic forecasts give additional incentives to manage earnings to meet or beat the forecast; (3) cognitive biases in managerial decisions are in general recognized by the market and impounded into the share price (e.g., Malmendier and Tate, 2008; Hillary and Hsu, 2011); and (4) investors recognize earnings management around earnings thresholds, and in the period after 2001 they view small positive earnings surprises as implicit evidence of earnings management, punishing all firms that meet or just beat earnings thresholds, regardless of whether earnings management actually took place (e.g., Bartov et al., 2002; Kasznik and McNichols, 2002; Skinner and Sloan, 2002; Keung et al., 2010). Based on these findings, we expect that investors recognize not only managerial overoptimism but also the higher earnings management incentives of overoptimistic CEOs and that they take these incentives into account as soon as they are revealed, which is at the management forecast date.

To investigate this expectation, we examine not only the market reaction to the management forecast at the forecast date but also the market reaction to earnings announcements at the earnings announcement date. We focus on the earnings announcement date in addition to the management forecast date for two reasons. First, an underreaction to forecasts issued by overoptimistic managers could be explained by the lower credibility of biased forecasts rather than by the earnings management incentives. The underreaction at the forecast date is thus a necessary but not a sufficient condition to support our expectation. Second, if investors react to earnings management by 


\section{CHAPTER 2 \\ Market Reaction to Higher Earnings Management Incentives Implicit in the Earnings Forecasts of Overoptimistic CEOs}

overoptimistic CEOs only at the earnings announcement date, the market reaction to earnings of overoptimistic CEOs should not be different from that of an average firm. The market reaction to the earnings of overoptimistic CEOs will only be different if increased earnings management incentives of overoptimistic managers have already been incorporated into the share price at the forecast date. Thus, the earnings announcement date provides a powerful setting to test our predictions regarding the market reaction to earnings management incentives of overoptimistic CEOs. More specifically, we predict that while non-optimistic firms are punished for small positive forecast errors at the earnings announcement date, which indicate that earnings might have been managed, the market will not react to small positive forecast errors of overoptimistic managers because earnings management incentives have already been impounded into the share price at the forecast date. If, however, subsequent earnings realizations by overoptimistic CEOs do not correspond with the market's expectations, i.e., overoptimistic CEOs do not seem to have managed earnings, a correction of the price takes place at the earnings announcement date. The market will hence react positively to small negative forecast errors from overoptimistic managers to correct for the unrealized earnings management.

Our measure of overoptimism is conceptually based on the measure first introduced by Malmendier and Tate (2005) and since then validated by many other empirical studies on cognitive biases (e.g., Li et al., 2010; Campbell et al., 2011; Hribar and Yang, 2011). Specifically, we identify overoptimistic CEOs based on the percentage of the intrinsic value of unexercised exercisable options to the value of total equity holdings of the CEO at the beginning of the year. In testing our hypothesis, we use propensity score matching to generate a proper control sample for our overoptimistic firm-year observations.

We first confirm that investors underreact to management forecasts of overoptimistic managers when the forecast is issued. We subsequently show that the market reacts more positively to the earnings announcements of overoptimistic CEOs in the small forecast error range compared to those of non-optimistic managers. This implies that at least part of the negative reaction at the forecast date is driven by the market impounding the earnings management incentives of overoptimistic managers. As a 


\section{CHAPTER 2 \\ Market Reaction to Higher Earnings Management Incentives Implicit in the Earnings Forecasts of Overoptimistic CEOs}

consequence, investors do not react to the inferred earnings management of these CEOs at the earnings announcement date in case of small positive forecast errors. In addition, investors react more positively to the perceived lack of earnings management by overoptimistic CEOs compared to non-optimistic managers at the earnings announcement date in case of small negative forecast errors.

We contribute to the literature in a number of ways. First, we contribute to the literature on market reactions to public disclosures. We show that a managerial cognitive bias, specifically CEO overoptimism, is an additional factor in explaining the market reaction to the issuance of management forecasts and the subsequent earnings announcement, because the market recognizes the higher earnings management incentives of overoptimistic managers and reacts to them early.

We also contribute to the literature on cognitive biases, especially those examining overoptimism and overconfidence, by separating overoptimism from overconfidence in an empirical setting. In the management forecasting context, forecast accuracy relates to for overconfidence, while forecast error relates to overoptimism. We examine the consequences of CEO overoptimism by not only considering the size of the forecast error but also its sign. In addition, while prior research focuses on the market reaction to overconfident forecasts at the announcement of the forecast (Hilary and Hsu, 2011), we investigate whether there is a different market reaction to accounting information disclosed by overoptimistic managers at the earnings announcement date. We show that the market recognizes overoptimism and the associated incentives to manage earnings, incorporates these incentives into the share price already at the forecast date, and hence either does not react or adjusts its prior expectations at the earnings announcement date.

We contribute to the earnings management literature by examining whether the market is fooled by earnings management incentives. More specifically we contribute to the literature on earnings management around thresholds. We show that beyond the three classic earnings thresholds, analyst forecasts, prior year earnings and zero earnings, examined in the earnings management literature (e.g., Degeorge et al., 1999), management forecasts are also considered an earnings benchmark both by managers and 


\section{CHAPTER 2 \\ Market Reaction to Higher Earnings Management Incentives Implicit in the Earnings Forecasts of Overoptimistic CEOs}

investors. In addition, while prior studies show that firms are punished for beating benchmarks at the earnings announcement date after 2001 (e.g., Keung et al., 2010), we show that the discounting depends on the extent to which the market has already incorporated the incentives to manage earnings early on.

The paper proceeds as follows. Section 2 discusses prior literature and develops our hypothesis. Section 3 presents the sample selection procedures and empirical design. Section 4 presents our results and Section 5 concludes.

\subsection{Prior Research and Hypothesis Development}

\subsubsection{Cognitive Biases and Managerial Decisions}

Recently, great progress has been made in economics, finance, and accounting research in examining the economic effects of cognitive biases (e.g., Malmendier and Tate, 2005 and 2008; Billett and Qian, 2008; Hilary and Hsu, 2011; Hribar and Yang, 2011). With regard to management decision making, the focus has been on the cognitive biases of overoptimism and overconfidence. Overoptimism and overconfidence are defined with regard to predictions of the future (Ben-David et al., 2010). The theoretical construct of overoptimism is defined as the overestimation of the mean of future random events or risky processes, while overconfidence is an underestimation of the variance of future random events.

Prior research confirms that overoptimism and overconfidence are common traits of managers and that these cognitive biases affect their real economic decisions (e.g., Roll, 1986; Malmendier and Tate, 2005; Ben-David et al., 2010). Roll (1986) examines the motives for mergers and acquisitions, and offers an alternative hypothesis - managerial hubris - to explain prior empirical results. The author argues and finds that cognitively biased managers overpay for target companies. Camerer and Lovallo (1999) use an experimental setting to show that optimistic biases of entrepreneurs affect the decision to enter a competitive market and suggest that this optimism explains the high rate of business failures observed. Using a theoretical model, Heaton (2002) also shows 


\section{CHAPTER 2 \\ Market Reaction to Higher Earnings Management Incentives Implicit in the Earnings Forecasts of Overoptimistic CEOs}

that overoptimism affects managerial decisions about the financing of investment projects. Overoptimistic managers may reject positive net present value (NPV) projects that require external financing, as they believe that the market undervalues their firm. Alternatively, they may invest in negative NPV projects, because they overvalue them. Ben-David et al. (2010) examine the effect of overconfidence and overoptimism on the investment behavior of CFOs. Using their survey-based measure, the authors distinguish between overconfidence and overoptimism. They find that CFOs' cognitive biases affect capital-budgeting decisions: Corporate investment levels increase with both overconfidence and overoptimism. Malmendier and Tate (2005) also conclude that overconfidence affects corporate investment decisions: Overconfidence results in a higher cash-flow sensitivity of investments, distorting investment decisions. Because overconfident CEOs overestimate project returns but believe that the market undervalues their firm, they overinvest if funds are available internally and underinvest if external funds are required. Finally, using a dynamic measure of overconfidence, Billett and Qian (2008) conclude that overconfidence leads to managers making more acquisitions.

In addition to investment and acquisition decisions, it has been shown that cognitive biases also affect management forecasting behavior (e.g., Hilary and Hsu, 2011; Hribar and Yang, 2011). Using a dynamic definition of overconfidence, Hilary and Hsu (2011) examine whether managers become overconfident in their future earnings forecasts. They find that the subsequent earnings forecasts of overconfident managers become less accurate. Hribar and Yang (2011) show that the characteristics of cognitively biased forecasts differ. They find that 'overconfident' managers are more likely to issue earnings forecasts, to issue forecasts with higher precision - proportionately more point than range forecasts and narrower range forecasts -, and that their forecasts are higher on average resulting in a higher probability of negative forecast errors. ${ }^{4}$

\footnotetext{
${ }^{4}$ Although Hribar and Yang (2013) call their construct 'overconfidence', they acknowledge that they actually examine CEO overoptimism.
} 


\section{CHAPTER 2 \\ Market Reaction to Higher Earnings Management Incentives Implicit in the Earnings Forecasts of Overoptimistic CEOs}

\subsubsection{Market Reaction to Biased Forecasts}

Accounting research has established that the market reacts to management earnings forecasts (Patell, 1976; Penman, 1980), specifically to the earnings news in management forecasts. Since then it has also been shown that in their reaction to management forecasts investors behave rationally: depending on firm size, forecast horizon, forecast news, and forecast credibility, the market recognizes the predictable bias when forecasts are issued and does not react to it (Choi and Ziebart, 2004; Rogers and Stocken, 2005; Hutton and Stocken, 2007; Ng et al., 2010). In addition, prior literature not only shows that cognitive biases affect managerial behavior, but also that investors recognize the cognitive biases and cognitively biased corporate decisions, and discount them (e.g., Statman and Sepe, 1989; Malmendier and Tate, 2008; Billett and Qian, 2008). The study of Hilary and Hsu (2011) is the only one so far to examine the market reaction to cognitively biased management forecasts. They find that the market reaction to overconfident forecasts at the time the forecast is issued is lower: The market discounts the earnings/forecast news.

\subsubsection{Earnings Management Thresholds}

The literature on earnings management around thresholds suggests that firms manage their earnings to meet or beat three earnings benchmarks: zero earnings, prior year's earnings and analyst forecasts (Burgstahler and Dichev, 1997; Degeorge et al., 1999). Although the literature on earnings management around thresholds does not explicitly consider management forecasts, Trueman (1986) and Kasznik (1999) show that it can be costly for managers and firms to miss their own forecasts because of loss of reputation, threat of litigation, or negative price movements. Kasznik (1999) shows that firms make attempts to meet their forecasts through the use of income-increasing discretionary accruals, and that the level of earnings management is increasing in the expected costs of missing the forecast. Therefore it is reasonable to argue that managers' forecasts act as a benchmark and managers have incentives to meet or beat their own earnings forecasts.

Hribar and Yang (2011) show that the forecasts issued by overoptimistic managers are more optimistic than forecasts issued by the average manager. Given that 


\section{CHAPTER 2 \\ Market Reaction to Higher Earnings Management Incentives \\ Implicit in the Earnings Forecasts of Overoptimistic CEOs}

managers' forecasts act as an earnings threshold that managers try to meet or beat (Trueman, 1986; Kasznik, 1999), a more optimistic forecasts will be more difficult to meet or beat, which results in additional incentives to manage earnings to meet or beat the forecast (Schrand and Zechman, 2011). If investors recognize overoptimism and its consequences, i.e., increased earnings management incentives, they will rationally incorporate these incentives into the share price at the forecast date.

Literature has shown that investors recognize earnings management around thresholds (e.g., Bartov et al., 2002; Kasznik and McNichols, 2002; Skinner and Sloan, 2002; Keung et al., 2010): Investors react differently to earnings just below and just above earnings thresholds at the earnings announcement date. Prior to 2001, firms had incentives to manage earnings to meet or beat the earnings benchmarks because firms meeting and beating the benchmarks were rewarded, while those missing earnings benchmarks were punished by the market (e.g., Bartov et al., 2002; Kasznik and McNichols, 2002; Skinner and Sloan, 2002). However, after 2001, investors' attitude to perceived earnings management has changed: Firms collectively incur a cost for playing the numbers game around earnings thresholds. Investors view small positive earnings surprises as implicit evidence of earnings management, even after controlling for the sign of estimated discretionary accruals and punish all firms that meet or just beat earnings thresholds, regardless of whether earnings management actually took place (Keung et al., 2010).

Based on the above we argue that CEO overoptimism leads to more optimistic forecasts and given that CEOs' own forecasts act as an earnings benchmark, overoptimistic CEOs have additional incentives to manage their earnings. Rational investors who recognize overoptimistic managers and the additional earnings management incentives of overoptimistic managers, impound this information into the share price when the earnings forecast is issued. If subsequent earnings realizations reveal a small positive forecast error, then this fits the market's expectations and there is no additional market reaction at the earnings announcement date for overoptimistic managers (see Table2.1). If, however, subsequent earnings realizations by overoptimistic CEOs reveal a small negative forecast error, then this does not fit the market's 


\section{CHAPTER 2 \\ Market Reaction to Higher Earnings Management Incentives Implicit in the Earnings Forecasts of Overoptimistic CEOs}

expectations and a correction of the share price takes place at the earnings announcement date.

Based on Keung et al. (2010), we expect that, in the period following 2001, the market (1) reacts negatively to small positive forecast errors of the average firm, because the market reacts negatively to signs of unexpected earnings management at the earnings announcement date; (2) does not react or reacts positively to small negative forecast errors of the average firm, because the market does not react to small negative earnings realizations or appreciates the lack of earnings management by these firms (see Table 2.1).

Table 2.1 - Hypothesis Development: Market Reaction to the Earnings Announcement

\begin{tabular}{lcccc}
\hline & \multicolumn{4}{c}{ Management Forecast Error } \\
\cline { 2 - 5 } & $\begin{array}{c}\text { Large } \\
\text { negative } \\
\text { MEF }>>\text { EPS }\end{array}$ & $\begin{array}{c}\text { Small } \\
\text { negative } \\
\text { MEF }>\text { EPS }\end{array}$ & $\begin{array}{c}\text { Small } \\
\text { positive } \\
\text { MEF }<=\text { EPS }\end{array}$ & $\begin{array}{c}\text { Large } \\
\text { positive } \\
\text { MEF }<<\text { EPS }\end{array}$ \\
\cline { 2 - 5 } Overoptimistic CEOs & $? /-$ & + & 0 & $? /+$ \\
Non-optimistic CEOs & -- & $+/ 0$ & - & ++ \\
Difference & $? /+$ & + & + & $? /+$
\end{tabular}

Management Forecast Error (MFE) is the management forecast error and is equal to realized earnings (actual EPS from FC Actuals) less the first annual management EPS forecast (from FCCIG). Management Earnings Forecast $(\mathrm{MEF})$ is the first annual EPS forecast issued by the firm. Overoptimistic CEOs are CEOs whose wealth is overexposed to the idiosyncratic risk of their firm, measured as a lagged indicator variable, equal to one, if the intrinsic value of the unexercised exercisable options to the value of the total equity holdings of the CEO is equal to or higher than $67 \%$, and zero otherwise. Large Positive Forecast Error is the MFE if MEF is higher than EPS by more than a few dollar cents, i.e. MFE is very positive (in this paper above $2 \phi$ ), and zero otherwise. Large Negative Forecast Error is the MFE if MEF is lower than EPS by more than a few dollar cents, i.e. MFE is very negative (in this paper below -2ф), and zero otherwise. Small Positive Forecast Error is the MFE if MEF is equal to or higher than EPS by a few dollar cents, i.e. MFE is zero or slightly positive (in this paper between $2 \varnothing$ and $0 \varnothing$ ), and zero otherwise. Small Negative Forecast Error is the MFE if MEF is less than EPS by a few dollar cents, i.e. MFE is slightly negative (in this paper between $0 \notin$ and $-2 \phi$ ), and zero otherwise.

In sum, while the average firm is expected to be punished for small positive forecast errors, as the market views it as a sign of earnings management, the small positive forecast errors of overoptimistic managers will be ignored by the market because these were expected and have already been incorporated into the share price at the forecast date. In turn, the small negative forecast errors of the average firm are expected to be either ignored or slightly appreciated by the market, but the market reaction to small negative 


\section{CHAPTER 2 \\ Market Reaction to Higher Earnings Management Incentives Implicit in the Earnings Forecasts of Overoptimistic CEOs}

forecast errors of overoptimistic managers will be positive. In sum, the market reaction to small positive and small negative forecast errors is expected to be more positive for overoptimistic CEOs in comparison to the average firm. Therefore, we posit the following hypothesis:

H: $\quad$ The market reaction to small positive and small negative forecast errors of overoptimistic CEOs at the earnings announcement date is more positive compared to those of non-overoptimistic managers.

\subsection{Sample and Empirical Design}

\subsubsection{Sample}

We use the First Call Company Issued Guidance (FCCIG) database to obtain a sample of annual US management earnings forecasts of earnings per common share (EPS), issued for the fiscal years 2002 to 2006 .

We use EPS forecasts because earnings forecasts, as a major source of voluntary financial accounting information, are the most common type of forecasts that firms provide, hence they constitute the majority of forecasts in FCCIG. We use annual earnings forecasts because fiscal year-ends are the most important reporting dates (Oyer, 1998) and therefore incentives to manage earnings might be higher for annual earnings. For each fiscal year-end we include the first forecast because longer term forecasts are found to be more optimistic (Hirst et al., 2008).

In line with the arguments of Rogers and Stocken (2005), who limit their sample to a period when the legal environment affecting management forecasting behavior is unchanged, we limit our sample to after the end of 2001, when the passing of the Sarbanes-Oxley Act has changed investor attitudes to earnings management. We exclude observations from fiscal years 2007 and beyond, because of the financial crisis. 


\section{CHAPTER 2 \\ Market Reaction to Higher Earnings Management Incentives Implicit in the Earnings Forecasts of Overoptimistic CEOs}

Management earnings forecasts of the FCCIG database are classified by type or specificity: point, range, open-ended, confirming or qualitative forecasts. We use forecasts where a point forecast can be estimated because Rogers and Stocken (2005) state that markets can make better use of forecasts if those can be compared to realized earnings unambiguously. If the forecast is a point forecast we use the forecast value explicitly provided by the firm. If the forecast is a range (closed-interval) forecast with no further qualification by management we use the midpoint of the range (i.e., the average of the two endpoints) provided by the firm. Prior research suggests that investor earnings expectations are formed based on the midpoint of a range forecast (e.g., Baginski et al., 1993; Hirst et al., 1999). However, if statements by management relating to the range forecasts included in the FCCIG database indicate that earnings per share would be at the low (high) end of the range we use the low (high) end of the range as the value for the forecast in line with Hutton and Stocken (2007). In addition to point and range forecasts we also use open-ended (open interval, maximum and minimum) and non-point confirming forecasts, similarly to Baginski et al. (1993) and Hutton and Stocken (2007). If the forecast is an open-ended forecast or open-ended confirming forecast we use the endpoint (upper or lower bound) given by the firm. If the open-ended forecast is determined in comparison to 0, we use 0 in line with Baginski et al. (1993) and Hutton and Stocken (2007). Qualitative forecasts are excluded.

Of the initial sample of 27,832 annual EPS forecasts we drop observations with missing forecasts and no identifiable numerical forecast (308 observations). In line with Rogers and Stocken (2005) and Hutton and Stocken (2007), we drop forecasts issued on or after the fiscal year-end to exclude earnings pre-announcements or earnings warnings and forecasts that might have erroneous forecast dates, e.g. forecast dates recorded as being after the data entry date (847 observations). We keep the first forecast per firm (drop 19,244 observations).

We exclude observations with insufficient data on First Call Actuals, First Call Estimates, Compustat, CRSP, and ExecuComp databases needed to compute our variables. After merging the different databases for the sample period 2002 to 2006, a 
final sample of 1,059 firms and 3,171 firm-year observations remain. The sample development procedures are summarized in Table 2.2 .

Table 2.2 - Sample Selection

\begin{tabular}{lcc}
\hline & \# Forecasts & \# Firm \\
\hline $\begin{array}{l}\text { FCCIG dataset of annual EPS forecasts, } \\
\text { for fiscal years } 2002 \text { to } 2006\end{array}$ & 27,832 & 2,741 \\
Missing or non-numerical forecast & $(308)$ & $(30)$ \\
\cline { 2 - 3 } $\begin{array}{l}\text { Earnings pre-announcements, earnings warnings, } \\
\text { erroneous forecast dates }\end{array}$ & 27,524 & 2,711 \\
$\begin{array}{l}\text { Duplicate forecasts for same fiscal year-end } \\
\text { (keeping the first forecast) }\end{array}$ & $(847)$ & $(79)$ \\
\cline { 2 - 3 } & $(19,244)$ & 2,632 \\
\cline { 2 - 3 } Insufficient data & 7,433 & - \\
\hline & $(4,262)$ & $(1,573)$ \\
\cline { 2 - 3 } Full sample & $\mathbf{3 , 1 7 1}$ & $\mathbf{1 , 0 5 9}$ \\
\hline
\end{tabular}

Table 2.3 describes the distributional properties of the full sample. The number of management earnings forecasts in our sample increases in the first years of the sample period (see Panel A of Table 2.3). According to Hutton and Stocken (2007) this is likely due to the introduction of Regulation Fair Disclosure on October 23, 2000, as a result of which managers are more likely to issue forecasts publicly. The number of forecasts issued by overoptimistic CEOs continues to increase towards the last years of our sample period in sharp contrast to those issued by non-optimistic CEOs. About 14 percent of the forecasts included in our sample are point forecasts, over 80 percent are range forecasts and less than five percent are open-ended (see Panel B of Table 2.3). The proportion of point forecasts is slightly higher for overoptimistic CEOs, in line with the findings of Hribar and Yang (2013) that forecasts issued by overoptimistic CEOs are more specific. The distribution of management forecasts across industries shows that more than ten percent are issued by companies from the Business Services and Retail sector (see Panel 


\section{CHAPTER 2 \\ Market Reaction to Higher Earnings Management Incentives \\ Implicit in the Earnings Forecasts of Overoptimistic CEOs}

C of Table 2.3). The distribution of forecasts issued by overoptimistic and non-optimistic managers across industries are very similar.

Table 2.3 - Distributional Properties of Full Sample

\begin{tabular}{ccccccc}
\hline $\begin{array}{c}\text { Panel A - Number of Forecasts per Fiscal Year and CEO Optimism } \\
\text { Fiscal year }\end{array}$ & \multicolumn{2}{c}{ Overoptimistic } & Non-optimistic & \multicolumn{2}{c}{ Full sample } \\
& $\mathrm{N}$ & $\%$ & $\mathrm{~N}$ & $\%$ & $\mathrm{~N}$ & $\%$ \\
$\mathbf{2 0 0 2}$ & 64 & 14.04 & 503 & 18.53 & 567 & 17.88 \\
$\mathbf{2 0 0 3}$ & 92 & 20.18 & 523 & 19.26 & 615 & 19.39 \\
$\mathbf{2 0 0 4}$ & 73 & 16.01 & 598 & 22.03 & 671 & 21.16 \\
$\mathbf{2 0 0 5}$ & 101 & 22.15 & 556 & 20.48 & 657 & 20.72 \\
$\mathbf{2 0 0 6}$ & 126 & 27.63 & 535 & 19.71 & 661 & 20.85 \\
Total & 456 & 100.00 & 2,715 & 100.00 & 3,171 & 100.00 \\
\% of full sample & 14.38 & & 85.62 & & 100.00 & \\
\hline Panel B - Distribution of Forecast Type and CEO Optimism & & & & \\
Forecast specificity & Overoptimistic & Non-optimistic & Full sample \\
& $\mathrm{N}$ & $\%$ & $\mathrm{~N}$ & $\%$ & $\mathrm{~N}$ & $\%$ \\
Point & 70 & 15.35 & 375 & 13.81 & 445 & 14.03 \\
Range & 366 & 80.26 & 2,211 & 81.44 & 2,577 & 81.27 \\
Open-ended & 20 & 4.39 & 129 & 4.75 & 149 & 4.70 \\
Total & 456 & 100.00 & 2,715 & 100.00 & 3,171 & 100.00 \\
\hline
\end{tabular}

Overoptimistic CEOs are CEOs whose wealth is overexposed to the idiosyncratic risk of their firm. We measure overoptimism as a lagged indicator variable, equal to one, if the intrinsic value of the unexercised exercisable options to the value of the total equity holdings of the CEO is equal to or higher than $67 \%$, and zero otherwise. 


\section{CHAPTER 2}

Market Reaction to Higher Earnings Management Incentives Implicit in the Earnings Forecasts of Overoptimistic CEOs

Table 2.3 - Distributional Properties of Full Sample (contd)

\begin{tabular}{|c|c|c|c|c|c|c|}
\hline \multicolumn{7}{|c|}{ Panel C - Number of Forecasts per Industry (Fama-French 48) and CEO Optimism } \\
\hline \multirow[t]{2}{*}{ Industry } & \multicolumn{2}{|c|}{ Overoptimistic } & \multicolumn{2}{|c|}{ Non-optimistic } & \multicolumn{2}{|c|}{ Full sample } \\
\hline & $\mathrm{N}$ & $\%$ & $\mathrm{~N}$ & $\%$ & $\mathrm{~N}$ & $\%$ \\
\hline Agric-Agriculture & 1 & 0.22 & 14 & 0.52 & 15 & 0.47 \\
\hline Food - Food Products & 14 & 3.07 & 66 & 2.43 & 80 & 2.52 \\
\hline Soda - Candy \& Soda & 0 & 0.00 & 12 & 0.44 & 12 & 0.38 \\
\hline Beer - Beer \& Liquor & 1 & 0.22 & 17 & 0.63 & 18 & 0.57 \\
\hline Tobacco - Tobacco Products & 1 & 0.22 & 12 & 0.44 & 13 & 0.41 \\
\hline Toys - Recreation & 1 & 0.22 & 17 & 0.63 & 18 & 0.57 \\
\hline Fun - Entertainment & 3 & 0.66 & 6 & 0.22 & 9 & 0.28 \\
\hline Books - Printing \& Publishing & 4 & 0.88 & 31 & 1.14 & 35 & 1.10 \\
\hline Hshld - Consumer Products & 6 & 1.32 & 75 & 2.76 & 81 & 2.55 \\
\hline Clths - Apparel & 10 & 2.19 & 66 & 2.43 & 76 & 2.40 \\
\hline Hlth - Healthcare & 12 & 2.63 & 69 & 2.54 & 81 & 2.55 \\
\hline MedEq - Medical Equipment & 39 & 8.55 & 98 & 3.61 & 137 & 4.32 \\
\hline Drugs - Parmaceutical Products & 27 & 5.92 & 143 & 5.27 & 170 & 5.36 \\
\hline Chems - Chemicals & 6 & 1.32 & 73 & 2.69 & 79 & 2.49 \\
\hline Rubbr - Rubber \& Plastic Products & 1 & 0.22 & 14 & 0.52 & 15 & 0.47 \\
\hline Txtls - Textiles & 0 & 0.00 & 5 & 0.18 & 5 & 0.16 \\
\hline BldMt - Construction Materials & 2 & 0.44 & 36 & 1.33 & 38 & 1.20 \\
\hline Cnstr - Construction & 14 & 3.07 & 60 & 2.21 & 74 & 2.33 \\
\hline Steel - Steel Works & 2 & 0.44 & 12 & 0.44 & 14 & 0.44 \\
\hline FabPr - Fabricated Products & 2 & 0.44 & 8 & 0.29 & 10 & 0.32 \\
\hline Mach - Machinery & 13 & 2.85 & 117 & 4.31 & 130 & 4.10 \\
\hline ElcEq - Electrical Equipment & 8 & 1.75 & 35 & 1.29 & 43 & 1.36 \\
\hline Autos - Automobiles \& Trucks & 3 & 0.66 & 33 & 1.22 & 36 & 1.14 \\
\hline Aero-Aircraft & 11 & 2.41 & 19 & 0.70 & 30 & 0.95 \\
\hline Ships - Shipbuilding, Railroad Equipment & 0 & 0.00 & 4 & 0.15 & 4 & 0.13 \\
\hline Guns - Defense & 2 & 0.44 & 10 & 0.37 & 12 & 0.38 \\
\hline Gold - Precious Metals & 0 & 0.00 & 1 & 0.04 & 1 & 0.03 \\
\hline Mines - Non-Metallic \& Industrial Metal Mining & 3 & 0.66 & 9 & 0.33 & 12 & 0.38 \\
\hline Coal - Coal & 1 & 0.22 & 5 & 0.18 & 6 & 0.19 \\
\hline Oil - Petroleum \& Natural Gas & 5 & 1.10 & 49 & 1.80 & 54 & 1.70 \\
\hline Util - Utilities & 15 & 3.29 & 252 & 9.28 & 267 & 8.42 \\
\hline Telcm - Communication & 5 & 1.10 & 34 & 1.25 & 39 & 1.23 \\
\hline PerSv - Personal Services & 17 & 3.73 & 44 & 1.62 & 61 & 1.92 \\
\hline BusSv - Business Services & 63 & 13.82 & 340 & 12.52 & 403 & 12.71 \\
\hline Comps - Computers & 11 & 2.41 & 86 & 3.17 & 97 & 3.06 \\
\hline
\end{tabular}




\section{CHAPTER 2}

Market Reaction to Higher Earnings Management Incentives Implicit in the Earnings Forecasts of Overoptimistic CEOs

\begin{tabular}{lcccccc} 
Chips - Electronic Equipment & 13 & 2.85 & 86 & 3.17 & 99 & 3.12 \\
LabEq - Measuring \& Control Equipment & 20 & 4.39 & 56 & 2.06 & 76 & 2.40 \\
Paper - Business Supplies & 2 & 0.44 & 38 & 1.40 & 40 & 1.26 \\
Boxes - Shipping Containers & 1 & 0.22 & 15 & 0.55 & 16 & 0.50 \\
Trans - Transportation & 1 & 0.22 & 46 & 1.69 & 47 & 1.48 \\
Whls - Wholesale & 7 & 1.54 & 97 & 3.57 & 104 & 3.28 \\
Rtail - Retail & 69 & 15.13 & 253 & 9.32 & 322 & 10.15 \\
Meals - Restaurants, Hotels, Motels & 21 & 4.61 & 81 & 2.98 & 102 & 3.22 \\
Banks - Banking & 6 & 1.32 & 44 & 1.62 & 50 & 1.58 \\
Insur - Insurance & 8 & 1.75 & 71 & 2.62 & 79 & 2.49 \\
Fin - Trading & 3 & 0.66 & 36 & 1.33 & 39 & 1.23 \\
Other & 2 & 0.44 & 20 & 0.74 & 22 & 0.69 \\
Total & 456 & 100.00 & 2,715 & 100.00 & 3,171 & 100.00 \\
\hline
\end{tabular}

As shown in Table 2.4, compared to the average firm in the Compustat universe, the firms in our sample are much larger, more profitable and less likely to make a loss. This is caused by the characteristics of the databases we use to gather our sample: Both the ExecuComp and First Call database are biased towards larger companies.

Table 2.4 - Comparison of Compustat Firms and Full Sample ${ }^{a}$

\begin{tabular}{|c|c|c|c|c|c|c|c|}
\hline \multirow[b]{2}{*}{ Variable $^{b}$} & \multicolumn{3}{|c|}{ Compustat Firms } & \multicolumn{3}{|c|}{ Full Sample } & \multirow{2}{*}{$\begin{array}{c}\text { Difference } \\
\text { of Mean } \\
\text { t-test }^{\mathbf{c}}\end{array}$} \\
\hline & $\mathbf{N}$ & Mean & Std. Dev. & $\mathbf{N}$ & Mean & Std. Dev. & \\
\hline Total Assets & 16,583 & 2263.116 & 19985.040 & 3,171 & 9455.873 & 43141.170 & $-14.74 * * *$ \\
\hline Common Equity & 16,063 & 415.219 & 2235.938 & 3,171 & 2746.676 & 7348.291 & $-33.18 * * *$ \\
\hline Market Value & 13,092 & 789.877 & 3555.698 & 3,124 & 8839.697 & 26206.710 & $-33.87 * * *$ \\
\hline Net Income & 16,546 & 25.130 & 639.785 & 3,171 & 398.544 & 1379.177 & $-23.90 * * *$ \\
\hline Loss & 17,675 & 0.427 & 0.495 & 3,171 & 0.087 & 0.281 & $37.61 * * *$ \\
\hline
\end{tabular}




\section{CHAPTER 2 \\ Market Reaction to Higher Earnings Management Incentives Implicit in the Earnings Forecasts of Overoptimistic CEOs}

\subsubsection{Empirical Design}

\section{Propensity Score Matching}

In a first step, we use propensity score matching (PSM) to develop a good control sample for our overoptimistic CEO observations on which to test our hypothesis. Using this method we can generate a “"pseudo' random sample” (Lawrence et al., 2011:263) in which the overoptimism and non-optimism characteristic is randomly distributed across treated and non-treated observations, such that differences in observable characteristics between the two groups are reduced and the difference in the treatment effect, i.e., market reaction, will reflect the difference in CEO optimism only. PSM is appealing in cases such as ours where there are many confounding variables, a relatively few treated observations, but a large pool of potential controls, because in these cases a matched sample allows for better control of covariates. In addition, PSM can produce unbiased estimates of treatment effects, where the equivalence of treatment and control groups are immediately obvious (Rosenbaum and Rubin, 1983).

We use a logit model to estimate the propensity score, where our treatment variable is CEO overoptimism. In the estimation we include all observable variables that would be included in the empirical model to estimate the difference in market reaction, our outcome variable (Rosenbaum and Rubin, 1983; Armstrong et al., 2010). We then match overoptimistic with non-overoptimistic observations one-on-one, without replacement, using common support, with the smallest propensity score differences, and examine the covariate balance between the treatment and control samples.

The logit model to estimate the propensity score takes the following form (firm and time subscripts are suppressed):

$$
\mathrm{OPT}=\alpha_{0}+\alpha_{1} \mathrm{FNG}+\alpha_{2} \mathrm{FNB}+\text { Control variables }+\varepsilon
$$

The variables are defined as follows:

Overoptimism $(O P T)$ : Our overoptimism variable is based on Malmendier and Tate's (2005) measure of 'overconfidence' as modified by $\mathrm{Li}$ et al. (2010). The 


\section{CHAPTER 2 \\ Market Reaction to Higher Earnings Management Incentives Implicit in the Earnings Forecasts of Overoptimistic CEOs}

Malmendier and Tate (2005) measure, based on the option holdings behavior of CEOs, designates CEOs as overoptimistic if their wealth is overexposed to the idiosyncratic risk of their firm. Li et al. (2010) explain that as Malmendier and Tate (2005) use the length of the period that CEOs wait to exercise their options, which is proprietary data, they actually proxy for the proportion of unexercised exercisable options held by the CEO, using end-of-year holdings, which is publicly available. Li et al. (2010) use the percentage of the intrinsic value of the unexercised exercisable options to the value of the total equity holdings of the CEO, which is the sum of the value of unexercised exercisable options, unexercisable options, and shares of stock. ${ }^{5}$

We adjust our variable in two ways. First, we apply the Li et al. (2010) measure but, for the purpose of propensity score matching, we turn it into an indicator variable. Based on Malmendier and Tate (2005), we use 67 percent as the cutoff above which CEOs are classified as overoptimistic. Second, because we examine market reaction, we cannot assume that the market learns from contemporaneous activities and immediately acts on this knowledge. Therefore, we use a lagged overoptimism variable. Thus, our measure of overoptimism, denoted $\boldsymbol{O P T}$, is an indicator variable that is equal to one, i.e., CEOs are defined as overoptimistic, if the percentage of unexercised exercisable options to total holdings of the CEO in the previous fiscal year is equal to or higher than $67 \%$, and is zero otherwise.

Forecast News, Good and Bad $(F N G$ and $F N B)$ : Forecast news is the difference between the management earnings forecast and the market's earnings expectation for the firm. We measure the market's earnings expectation by the median analyst earnings per share forecast prevailing on the day of the management forecast, and deduct it from the first annual management EPS forecast issued by the firm for a given fiscal year. Forecast news is scaled by the stock price two days before the forecast date. Prior research suggests that markets react differently to good and bad news forecasts with bad news forecasts triggering a larger market response (e.g., Jennings 1987; Skinner 1994; Williams 1996;

\footnotetext{
${ }^{5}$ Estimated Value of In-the-Money Unexercised Exercisable Options / [Estimated Value of In-theMoney Unexercised Exercisable Options + Estimated Value Of In-the-Money Unexercised Unexercisable Options + Shares Owned - Options Excluded * Price Close - Annual - Fiscal]).
} 


\section{CHAPTER 2 \\ Market Reaction to Higher Earnings Management Incentives Implicit in the Earnings Forecasts of Overoptimistic CEOs}

Hutton et al., 2003; Choi and Ziebart, 2004; Hutton and Stocken, 2007). Therefore we split the forecast news variable into good news and bad news forecasts. Good news forecast, denoted $\boldsymbol{F N G}$, equals forecast news when the management forecast is above or equal to the current consensus median analyst forecast, and is zero otherwise. Bad news forecast, denoted $\boldsymbol{F N B}$, is equal to the forecast news when the management forecast is below the current consensus median analyst forecast, and is zero otherwise.

Control variables: Several variables are identified in prior studies to affect management forecasting behavior and the corresponding market reaction. The following variables are included in Model (1) to control for cross-sectional differences in forecast response coefficients.

The market reaction to the forecast news is influenced by the difficulty of forecasting earnings. Baginski et al. (1993) argue that managers reveal their uncertainty about earnings by issuing less specific forecasts. To proxy for the level of uncertainty revealed by the manager in the form of the forecast, denoted $\boldsymbol{S P E C}$, we use a categorical variable that equals zero for point forecasts, one for range forecasts, and two for openended forecasts (Baginski et al., 1993).

Firm characteristics also influence forecasting difficulty and hence the market reaction to the forecast. Prior research has shown that it is more difficult to forecast earnings if the firm reports a loss, is in distress, or performs poorly. As shown by Hayn (1995) and Basu (1997) it is more difficult to forecast a firm's earnings when the firm is unprofitable. To recognize this asymmetry, we include the indicator variable $\mathbf{L O S S}$. LOSS equals one either if the previous year's earnings are negative or the current year expected earnings of the firm, proxied by the consensus analysts' forecast, is negative, and zero otherwise (Choi and Ziebart, 2004).

Prior research shows that firms that perform poorly are more likely to issue optimistic earnings forecasts (Hribar and Yang, 2013). To control for firm performance we include return on assets, denoted $\boldsymbol{R} \boldsymbol{O} \boldsymbol{A}$, which is measured as net income divided by total assets.

Forecasting earnings might be more difficult if the firm's earnings are less persistent or more volatile. As Hutton and Stocken (2007) explain, forecast accuracy (or 


\section{CHAPTER 2 \\ Market Reaction to Higher Earnings Management Incentives Implicit in the Earnings Forecasts of Overoptimistic CEOs}

forecast bias) may reflect the characteristics of the firm's earnings generation process, which markets react to. Therefore we control for the firm's earnings volatility. Earnings volatility, denoted $\boldsymbol{E} \boldsymbol{V O L}$, is measured as the variance of earnings over the previous five years (Choi and Ziebart, 2004).

Prior research further shows that forecast errors decline, i.e., forecasts become less optimistic, as the time to the fiscal year-end decreases (e.g., Choi and Ziebart, 2004; Roger and Stocken, 2005; Hutton and Stocken, 2007; Choi et al., 2010; Hribar and Yang, 2013) because with later forecasts management faces less earnings uncertainty. We include the length of forecast horizon, denoted HORIZON, defined as the number of days between the forecast date and the firm's fiscal year-end (Rogers and Stocken, 2005).

We control for firm size because firm size affects forecasting behavior (Baginski and Hassell, 1997; Bamber and Cheon 1998; Rogers and Stocken, 2005): Larger firms provide more accurate forecasts (Waymire 1986; Lang and Lundholm 1993, 1996; Botosan and Plumlee, 2002), and smaller firms issue more optimistic forecasts (Hribar and Yang, 2013). We proxy for firm size, using the variable $\boldsymbol{S I Z E}$, by including the natural logarithm of the fiscal year's beginning market value of common equity (Choi et al., 2010; Hribar and Yang, 2013).

Prior research suggests that the number of analysts following the firm is associated with forecast precision (Lang and Lundholm, 1996; Baginski and Hassel, 1997; Choi and Ziebart, 2004; Choi et al., 2010; Hribar and Yang, 2013) because with more analysts more private information is available for investors and less private information acquisition is necessary. We include analyst following, denoted $\boldsymbol{N} \boldsymbol{A} \boldsymbol{N} \boldsymbol{A}$, measured as the number of analysts following the firm on the day of the management forecast.

We further control for growth opportunities because empirical evidence shows a relationship between growth opportunities, proxied by the market to book ratio, and management forecasting behavior (Bamber and Cheon, 1998; Hribar and Yang, 2013) and the market reaction to the management forecast (Skinner and Sloan, 2002). We include growth opportunities, denoted $\boldsymbol{M B}$, calculated as the ratio of market to book value of the firm's common equity at the beginning of the fiscal year (e.g., Choi et al., 2010). 


\section{CHAPTER 2 \\ Market Reaction to Higher Earnings Management Incentives Implicit in the Earnings Forecasts of Overoptimistic CEOs}

Finally, we control for industry-fixed effects based on the Fama and French (1997) 48 industry classification and time-series trends in forecasts (e.g., Choi and Ziebart, 2004; Rogers and Stocken, 2005; Hutton and Stocken, 2007). All continuous variables are winsorized at the 0.5 and 99.5 percent levels. Standard errors are heteroskedasticity robust.

\section{Stage 1 - Management Forecast Date}

Our theory requires us to confirm the differential market reaction to management forecasts issued by overoptimistic compared to non-optimistic CEOs at the forecast date. Hence, the dependent variable for Stage 1 is the event return around the management earnings forecast date, denoted $\boldsymbol{F C} \boldsymbol{A} \boldsymbol{R}_{-2,+2}$. It is defined as the cumulative daily return less the size-decile-matched CRSP Value-Weighted Index return over the five-day event window centered on the day of the management forecast, i.e., from two days before the forecast announcement date (day -2 ) to two days after the announcement date $($ day +2$)$. We report results using size-adjusted returns, where we calculate the size-decile return based on the ranking of the firm in June prior to the fiscal year of the management forecast. ${ }^{6}$

\section{Stage 2 - Earnings Announcement Date}

Our hypothesis predicts differential market reaction at the earnings announcement date to management forecast errors close to zero. More specifically, we predict that the market reacts more positively to the forecast errors of overoptimistic CEOs in small forecast error ranges compared to non-optimistic CEOs. We incorporate this in our empirical model in two ways (firm and time subscripts are suppressed):

$$
\text { ECAR }_{-2,+2}=\beta_{0}+\beta_{1} \text { OPT }+ \text { Control variables }+\varepsilon
$$

\footnotetext{
${ }^{6}$ The equal weighted cut-off points for the size portfolios are obtained from Professor Kenneth French's website:

http://mba.tuck.dartmouth.edu/pages/faculty/ken.french/data_library.html
} 


\section{CHAPTER 2 \\ Market Reaction to Higher Earnings Management Incentives Implicit in the Earnings Forecasts of Overoptimistic CEOs}

$$
\begin{aligned}
\text { ECAR }_{-2,+2}=\gamma_{0}+ & \gamma_{1} \mathrm{OPT}+\gamma_{2} \mathrm{SFE}+\gamma_{3} \mathrm{OPT} \times \mathrm{SFE} \\
& + \text { Control variables }+\varepsilon
\end{aligned}
$$

Regression (2a) is estimated in the small forecast error range, while regression (2b) is tested on the full matched sample. The variables are defined as follows:

Event Return at the Earnings Announcement Date $\left(E C A R_{-2,+2}\right)$ : The market response to the earnings announcement, denoted $\boldsymbol{E} \boldsymbol{C A} \boldsymbol{R}_{-2,+2}$, is the cumulative daily return less the size-decile-matched CRSP Value-Weighted Index return over the five-day event window centered on the day of the earnings announcement, i.e., from two days before the earnings announcement date (day -2$)$ to two days after the announcement date $($ day +2$)$. We report results using size-adjusted returns, where we calculate the size-decile return based on the rankings of the firm in June prior to the fiscal year of the firm. ${ }^{7}$

Small Forecast Error $(S F E)$ : The small forecast error, denoted $\boldsymbol{S F E}$, is defined as an indicator variable equal to one if the management forecast error is less than or equal to $\$ 0.01(0.02)$ and more than or equal to $\$-0.01(-0.02)$, and is zero otherwise. The management forecast error is equal to actual EPS less the first annual management EPS forecast. Keung et al. (2010) find a negative market reaction at a forecast error of $1 \varnothing$. However, because we use a matched sample, we only have a small number of observations in the $[-1 \phi ;+1 \phi]$ forecast error range, which may lead to a potential lack of power. Therefore, in addition to the $1 \varnothing$ range, we also test our regressions in the $2 \varnothing$ forecast error range.

Control variables: Several variables are identified in prior studies that are expected to affect the earnings response coefficient (e.g., Easton and Zmijewski, 1989; Collins and Kothari, 1989; Hayn, 1995; DeFond and Park, 2001; Bartov et al., 2002; Skinner and Sloan, 2002). Some of these variables (NANA, SIZE, MB, EVOL, IND, YEAR, defined above) are included in regression (1) to estimate the propensity score and are therefore controlled for by construction. We include a number of additional variables in regressions (2a) and (2b) to control for cross-sectional differences in the earnings

${ }^{7}$ The equal weighted cut-off points for the size portfolios are obtained from Professor Kenneth French's website: http://mba.tuck.dartmouth.edu/pages/faculty/ken.french/data_library.html 


\section{CHAPTER 2 \\ Market Reaction to Higher Earnings Management Incentives Implicit in the Earnings Forecasts of Overoptimistic CEOs}

response coefficient in line with Rogers and Stocken (2005), Hutton and Stocken (2007)

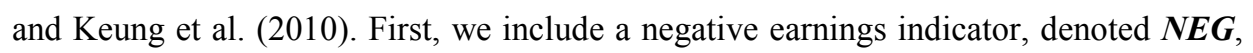
which is equal to one if year-end earnings are negative, and zero otherwise. Next, we add the amount of accruals, denoted $\boldsymbol{A C C}$, measured as beginning-of-year accruals scaled by average total assets. ${ }^{8}$ In addition, we include earnings news to control for the news in the earnings announcement. Earnings news is the difference between the earnings realization and the market's earnings expectation for the firm. We measure the market's earnings expectation by the median analyst earnings per share forecast prevailing on the day of the earnings announcement, and deduct it from realized EPS. Earnings news is scaled by the stock price two days before the earnings announcement date. Similar to the definition of the news variable at the management earnings forecast date, we split the earnings news variable into good news and bad news. The good news variable, denoted $\boldsymbol{E N G}$, equals earnings news when actual EPS is above or equal to the current consensus median analyst forecast, and zero otherwise. The bad news variable, denoted $\boldsymbol{E N B}$, is equal to the earnings news when actual EPS is below the current consensus median analyst forecast, and zero otherwise. All continuous variables are winsorized at the 0.5 and 99.5 percent levels. Standard errors are heteroskedasticity robust.

To confirm our hypothesis, we expect a positive sign on $\beta_{1}$, the coefficient of the overoptimism variable, in regression (2a), and a positive sign on $\gamma_{3}$, the coefficient of the interaction term, in regression (2b).

\subsection{Results}

\subsubsection{Propensity Score Matching}

The logit model we use to estimate the propensity score is run on the full sample $(3,149$ firm-years) with all variables of interest and control variables explained above $\left(\chi^{2}=\right.$ $190.82, \mathrm{p}<0.0000)$. We use the estimated propensity score to match overoptimistic with

\footnotetext{
${ }^{8}$ As defined by Hutton and Stocken (2007), the difference of Compustat items 123 and 308, i.e. the difference between Income Before Extraordinary Items (Cash Flow) and Operating Activities - Net Cash Flow.
} 


\section{CHAPTER 2 \\ Market Reaction to Higher Earnings Management Incentives Implicit in the Earnings Forecasts of Overoptimistic CEOs}

non-overoptimistic observations one-on-one, without replacement and using common support. Compared to the 456 overoptimistic observations we have a rich dataset of nonoptimistic firm-years. As a consequence, we are able to match 455 observations, losing only one overoptimistic observation, resulting in a matched sample of 910 firm-years. The matching appears effective as all variables included in the model are insignificantly different at the $10 \%$ level between the overoptimistic and non-optimistic observations in the matched sample. In addition, only five of the 455 matched pairs have a propensity score difference of $1 \%$ or higher. ${ }^{9}$

The success of the matching exercise can also be seen in Table 2.5, where differences in means are significant at the $10 \%$ level for four of the variables in the full sample, but none are significant in the matched sample.

\subsubsection{Stage 1 - Management Forecast Date}

Table 2.5 also shows that the market reaction to the management earnings forecast around the forecast date $(F C A R)$ is negative for overoptimistic managers $(-0.858 \%)$ and is positive for non-optimistic managers $(+0.217 \%)$ in the matched sample, and the difference is significant at $1 \%(\mathrm{t}=-3.28$, see Table 2.5$)$. The difference in the mean abnormal returns between overoptimistic and non-optimistic observations around the forecast announcement of $1.073 \%$ is also economically significant. This confirms our expectation that at the forecast date the market discounts the earnings forecasts issued by overoptimistic managers compared to those of non-optimistic managers.

\footnotetext{
${ }^{9}$ To test the robustness of our results to the precision of the match, we rerun tests where we exclude the five matched pairs (out of 455 ) with a propensity score difference higher than $1 \%$. In untabulated results, neither the difference in market reaction at the management earnings forecast (FCAR) in Stage 1 , nor the coefficients and their significance in the Stage 2 regressions change significantly.
} 


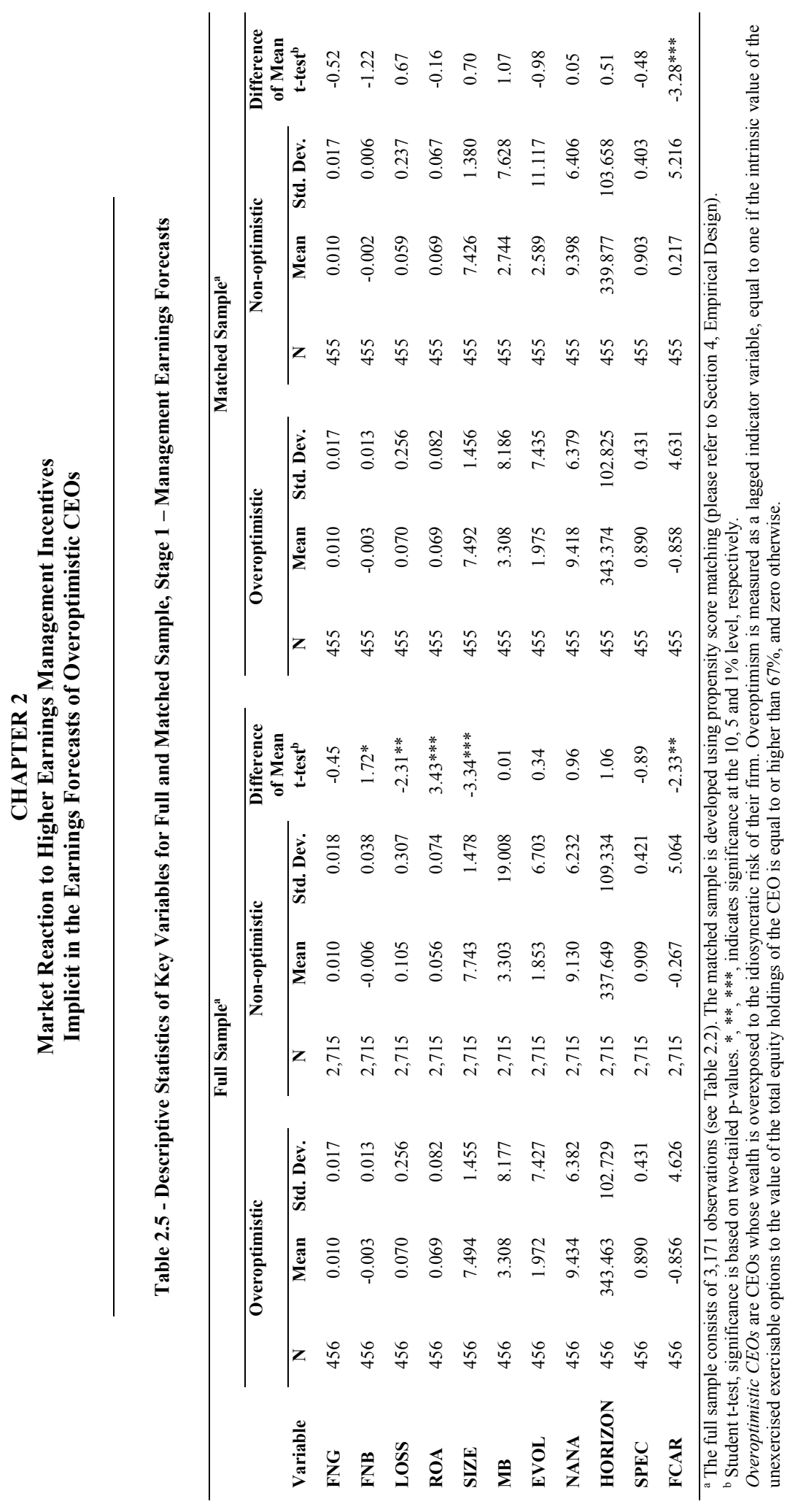




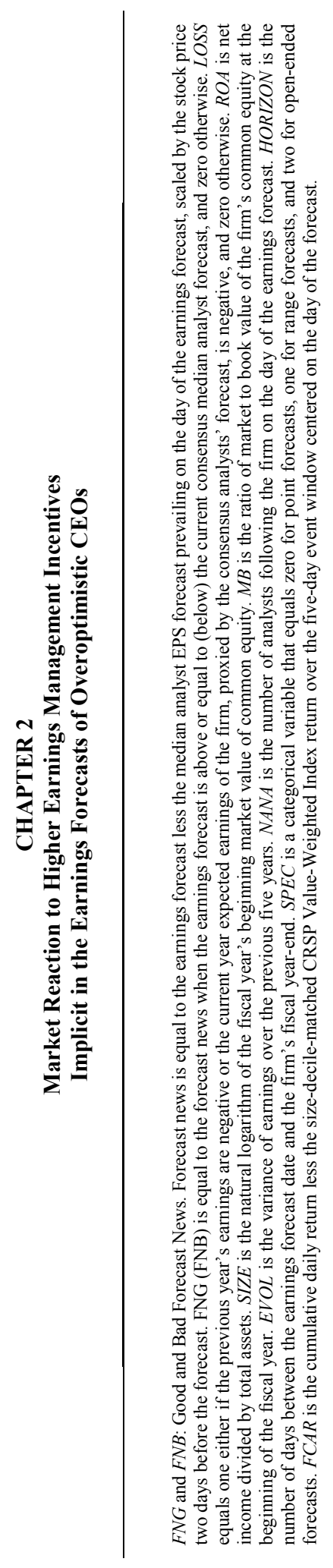




\section{CHAPTER 2 \\ Market Reaction to Higher Earnings Management Incentives Implicit in the Earnings Forecasts of Overoptimistic CEOs}

\subsubsection{Stage 2 - Earnings Announcement Date}

Table 2.6 shows that the matched sample observations do not differ significantly between the overoptimistic and non-optimistic groups in terms of the control variables used in our empirical tests at the earnings announcement date.

Table 2.6 - Descriptive Statistics of Key Variables for Matched Sample ${ }^{a}$

Stage 2 - Earnings Announcement Date

\begin{tabular}{|c|c|c|c|c|c|c|c|}
\hline \multirow[b]{2}{*}{ Variable } & \multicolumn{3}{|c|}{ Overoptimistic } & \multicolumn{3}{|c|}{ Non-optimistic } & \multirow{2}{*}{$\begin{array}{c}\text { Difference } \\
\text { of Mean } \\
\text { t-test }^{\mathbf{b}}\end{array}$} \\
\hline & $\mathbf{N}$ & Mean & Std. Dev. & $\mathbf{N}$ & Mean & Std. Dev. & \\
\hline NEG & 455 & 0.079 & 0.270 & 455 & 0.062 & 0.241 & 1.04 \\
\hline $\mathrm{ACC}$ & 455 & -0.064 & 0.195 & 455 & -0.052 & 0.061 & -1.24 \\
\hline ENG & 455 & 0.001 & 0.003 & 455 & 0.001 & 0.002 & 0.57 \\
\hline ENB & 455 & -0.001 & 0.009 & 455 & -0.001 & 0.005 & -0.64 \\
\hline ECAR & 455 & -0.044 & 3.980 & 455 & -0.019 & 4.281 & -0.09 \\
\hline
\end{tabular}

${ }^{a}$ The matched sample is developed using propensity score matching (please refer to Section 4, Empirical Design).

${ }^{\mathrm{b}}$ Student t-test, significance is based on two-tailed p-values.

$*, * *, * * *$, indicates significance at the 10,5 and $1 \%$ level, respectively.

Overoptimistic CEOs are CEOs whose wealth is overexposed to the idiosyncratic risk of their firm. Overoptimism is measured as a lagged indicator variable, equal to one if the intrinsic value of the unexercised exercisable options to the value of the total equity holdings of the CEO is equal to or higher than $67 \%$, and zero otherwise.

$N E G$ is one if year-end earnings are negative, and zero otherwise. $A C C$ is the beginning of year accruals scaled by average total assets. $E N G$ and $E N B$ : Earnings news equals realized EPS less the median analyst earnings per share forecast prevailing on the day of the earnings announcement, scaled by the stock price two days before the earnings announcement date; ENG (ENB) is equal to earnings news when the actual EPS is above or equal to (below) the current consensus median analyst forecast, and zero otherwise. ECAR is the cumulative daily return less the sizedecile-matched CRSP Value-Weighted Index return over the five-day event window centered on the day of the earnings announcement.

Table 2.7 reports the results of regressions (2a) and (2b) in the $1 \varnothing$ and $2 \varnothing$ management forecast error ranges. When examining the market reaction in the small forecast error ranges (Regression (2a)), we find that the sign on the coefficient of the overoptimism variable is positive and significant at the $5 \%$ level in both the $1 \varnothing\left(\beta_{1}=+1.71, \mathrm{p}=0.050\right.$, one-tailed) and $2 \varnothing\left(\beta_{1}=+2.24, p=0.037\right.$, one-tailed $)$ range, which is consistent with our hypothesis. This means that the market reaction to forecast errors of overoptimistic managers in the $1 \varnothing$ and $2 \phi$ ranges is $1.7 \%$ and $2.2 \%$ higher, respectively, compared to those of non-optimistic managers, which is an economically significant result. 


\section{CHAPTER 2 \\ Market Reaction to Higher Earnings Management Incentives \\ Implicit in the Earnings Forecasts of Overoptimistic CEOs}

Table 2.7 - Event Return Results

Stage 2 - Earnings Announcement Date

Event return regression results based on the following models:

$\mathrm{ECAR}_{-2,+2}=\beta_{0}+\beta_{1} \mathrm{OPT}+$ Control variables $+\varepsilon$

$\mathrm{ECAR}_{-2,+2}=\gamma_{0}+\gamma_{1} \mathrm{OPT}+\gamma_{2} \mathrm{SFE}+\gamma_{3} \mathrm{OPT} \times \mathrm{SFE}+$ Control variables $+\varepsilon$

\begin{tabular}{|c|c|c|c|c|c|}
\hline \multirow[b]{2}{*}{ Variable } & \multirow{2}{*}{$\begin{array}{c}\text { Predicted } \\
\text { Sign }\end{array}$} & \multicolumn{2}{|c|}{ Regression (2a) } & \multicolumn{2}{|c|}{ Regression (2b) } \\
\hline & & $1 d$ range & $2 c$ range & $1 c$ range & $2 c$ range \\
\hline OPT & + & $\begin{array}{c}2.239 * * \\
(0.037)\end{array}$ & $\begin{array}{l}1.708 * * \\
(0.050)\end{array}$ & $\begin{array}{l}-0.146 \\
(0.606)\end{array}$ & $\begin{array}{l}-0.214 \\
(0.456)\end{array}$ \\
\hline SFE & $0 /-$ & & & $\begin{array}{l}-1.212 * \\
(0.057)\end{array}$ & $\begin{array}{c}-1.150 * * \\
(0.048)\end{array}$ \\
\hline OPT x SFE & + & & & $\begin{array}{l}1.930^{*} \\
(0.056)\end{array}$ & $\begin{array}{c}1.942 * * \\
(0.025)\end{array}$ \\
\hline NEG & & $\begin{array}{c}-5.930 * * * \\
(0.001)\end{array}$ & $\begin{array}{c}1.444 \\
(0.570)\end{array}$ & $\begin{array}{l}-0.044 \\
(0.923)\end{array}$ & $\begin{array}{l}-0.043 \\
(0.926)\end{array}$ \\
\hline $\mathrm{ACC}$ & & $\begin{array}{l}-9.277 \\
(0.172)\end{array}$ & $\begin{array}{c}1.448 \\
(0.864)\end{array}$ & $\begin{array}{c}0.437 \\
(0.496)\end{array}$ & $\begin{array}{c}0.441 \\
(0.492)\end{array}$ \\
\hline ENG & & $\begin{array}{c}-105.750 \\
(0.693)\end{array}$ & $\begin{array}{l}15.256 \\
(0.963)\end{array}$ & $\begin{array}{l}20.799 \\
(0.669)\end{array}$ & $\begin{array}{l}21.894 \\
(0.654)\end{array}$ \\
\hline ENB & & $\begin{array}{c}-2,637.179 \\
(0.125)\end{array}$ & $\begin{array}{c}-577.111 \\
(0.679)\end{array}$ & $\begin{array}{c}1.381 \\
(0.869)\end{array}$ & $\begin{array}{l}1.165 \\
(0.889)\end{array}$ \\
\hline Constant & & $\begin{array}{c}-2.086^{* *} \\
(0.032)\end{array}$ & $\begin{array}{l}-1.196 \\
(0.173)\end{array}$ & $\begin{array}{c}0.068 \\
(0.755)\end{array}$ & $\begin{array}{c}0.093 \\
(0.674)\end{array}$ \\
\hline Observations & & 57 & 90 & 910 & 910 \\
\hline $\mathrm{R}^{2}$ & & 0.174 & 0.048 & 0.004 & 0.005 \\
\hline F-test & & 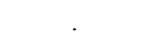 & 0.896 & 0.549 & 0.692 \\
\hline
\end{tabular}

Robust p-values reported in parentheses.

$*, * *, * *$ Significant at $10 \%, 5 \%, 1 \%$ levels, respectively, based on one-tailed tests where the sign of the coefficient is predicted, and two-tailed t-tests otherwise.

ECAR is the cumulative daily return less the size-decile-matched CRSP Value-Weighted Index return over the five-day event window centered on the day of the earnings announcement. $O P T$ is a lagged indicator variable, equal to one, if the intrinsic value of the unexercised exercisable options to the value of the total equity holdings of the CEO is equal to or higher than $67 \%$, and zero otherwise. $S F E$ is an indicator variable equal to one if the management forecast error (realized EPS less the first annual management EPS forecast) is less than or equal to $1 \phi$ and $2 \phi$ and more than or equal to $-1 \phi$ and $-2 \phi$, and is zero otherwise. $N E G$ is equal to one if year-end earnings are negative, and zero otherwise. $A C C$ is the beginning of year accruals scaled by average total assets. $E N G$ and $E N B$ : Earnings news is equal to realized EPS less the market's earnings expectation for the firm (proxied by the median analyst earnings per share forecast prevailing on the day of the earnings announcement), scaled by the stock price two days before the earnings announcement date. ENG (ENB) is equal to earnings news when the actual EPS is above or equal to (below) the current consensus median analyst forecast, and zero otherwise.

To provide further evidence that overoptimism has an impact on earnings announcements returns specifically in the small forecast error range, we examine the whole range of forecast errors and include an interaction term between overoptimism and the small 


\section{CHAPTER 2 \\ Market Reaction to Higher Earnings Management Incentives Implicit in the Earnings Forecasts of Overoptimistic CEOs}

forecast error indicator (Regression (2b)). We find a non-significant main effect for overoptimism and a significant positive interaction effect in both the $1 \not$ and $2 \phi$ forecast error range regressions. These findings suggest that the market reaction to earnings announcements of overoptimistic managers is not different from the market reaction to those of non-optimistic managers outside the small forecast error range (e.g., $\beta=-0.214$, $p=0.456$, one-tailed for $2 \phi$ ). However, within the small forecast error range, the market reaction to earnings announcements of overoptimistic managers is significantly different from that of non-optimistic managers and is even $1.7 \%$ higher (e.g., $\beta=+1.94-0.21=$ $+1.73, \mathrm{p}=0.035$, one-tailed for $2 \phi)$. Finally, the difference between these two effects is also statistically significant (e.g., $\beta=+1.94, \mathrm{p}=0.025$, one-tailed for $2 \varnothing$ ).

These results confirm our hypothesis that the market reacts more positively to the earnings announcements of overoptimistic CEOs in the small forecast error range compared to those of non-optimistic managers. Overall, our findings imply that investors react negatively to the higher earnings management incentives of overoptimistic managers when the management forecast is issued, but when earnings are announced they do not react to inferred earnings management of overoptimistic CEOs and react more positively to the inferred lack of earnings management by overoptimistic CEOs compared to non-optimistic managers.

\subsubsection{Additional Analyses}

\section{Overoptimism - Alternative Explanation}

We consider private information as an alternative explanation for CEOs holding onto their vested options, and hence our overoptimism measure. Malmendier and Tate (2005) argue that there are two main differences between overoptimism and inside information: persistence and performance. First, we examine persistence in two tests. Malmendier and Tate (2005) argue that while good information is transitory, a cognitive bias is persistent, therefore overoptimism can be differentiated from inside information. Although our overoptimism variable is a one-period measure, its persistence is high: in our matched sample, the correlation between the lagged and current overoptimism measure is 0.553 ( $p$ 


\section{CHAPTER 2 \\ Market Reaction to Higher Earnings Management Incentives Implicit in the Earnings Forecasts of Overoptimistic CEOs}

$<0.001$ ), while the coefficient of the current overoptimism measure regressed on the lagged one is $0.572(\mathrm{p}<0.001)$.

Despite the persistence in the measure of overoptimism, it is possible that CEOs are identified as overoptimistic in a particular year even though the proportion of their unexercised exercisable options was only once over the cutoff (67\%) during the whole period. Malmendier and Tate (2005) use an overoptimism measure that describes, what they call, a habitual tendency of CEOs. They set their measure as fixed for the whole sample period based on CEOs' options-holding behavior displayed on only two occasions. To test the robustness of our results based on an overoptimism measure characterized as more persistent, we redefine the CEOs in our sample as overoptimistic if the proportion of their unexercised exercisable options exceeded $67 \%$ at year-end at least twice during our sample period. The results are robust to this adjustment of our overoptimism measure. In particular, in the Stage 1 analysis, the market reaction to the management forecasts of overoptimistic CEOs is significantly lower than to those of nonoptimistic CEOs $(\mathrm{p}=0.076$, one-tailed). In the Stage 2 regressions, the important coefficients have the right signs in all regressions, and are significant in the $2 \not$ range $(\mathrm{p}<$ 0.08 , one-tailed), though not in the $1 \not$ range.

Second, we consider overoptimism and private information in terms of firm performance. If the CEO holds on to high proportions of unexercised exercisable stock options because of private information rather than overoptimism, the performance of their firm's stock should be better than that of CEOs who hold proportionally less vested options. We test the difference in performance by developing buy-and-hold portfolios from our matched sample firms and comparing abnormal returns of diversified and undiversified CEOs. We consider three holding periods following the measurement of our overoptimism variable: 3, 6 and 12 months from the beginning of the fiscal year, the point in time when we measure overoptimism. Table 2.8 shows the results of these tests. The differences in abnormal returns between overoptimistic and non-optimistic firms are not significant for the 3-and 6-month periods. The difference for the 12-month period is weakly significant ( $\mathrm{p}=0.076$, one-tailed), but the abnormal return is higher for nonoptimistic firms. We therefore conclude that the options holding behavior of 


\section{CHAPTER 2 \\ Market Reaction to Higher Earnings Management Incentives \\ Implicit in the Earnings Forecasts of Overoptimistic CEOs}

overoptimistic CEOs cannot be explained by them having better information than nonoptimistic CEOs.

Table 2.8 - Buy-and-Hold Returns ${ }^{\mathrm{a}}$ on Matched Sample

\begin{tabular}{|c|c|c|c|c|c|c|c|}
\hline \multirow[b]{2}{*}{ Period $^{\mathrm{b}}$} & \multicolumn{3}{|c|}{ Optimistic } & \multicolumn{3}{|c|}{ Non-optimistic } & \multirow{2}{*}{$\begin{array}{c}\text { Difference } \\
\text { of Mean } \\
\text { t-test }^{\mathrm{c}}\end{array}$} \\
\hline & $\mathbf{N}$ & Mean & Std. Dev. & $\mathbf{N}$ & Mean & Std. Dev. & \\
\hline 3 months & 455 & 0.025 & 0.166 & 455 & 0.029 & 0.155 & -0.33 \\
\hline 6 months & 455 & 0.038 & 0.259 & 455 & 0.047 & 0.247 & -0.49 \\
\hline 12 months & 455 & 0.032 & 0.318 & 455 & 0.062 & 0.303 & -1.44 \\
\hline
\end{tabular}

${ }^{a}$ Buy-and-hold returns are calculated as the difference between firm buy-and-hold returns less the sizedecile-matched CRSP Value-Weighted Index buy-and-hold returns over the holding period.

${ }^{\mathrm{b}}$ Buy-and-hold periods start at the beginning of the fiscal year: the number of months represent the first $3 / 6 / 12$ months of the fiscal year.

${ }^{c}$ Student t-test, significance is based on two-tailed p-values.

\section{Alternative event window specification}

In the main analysis, event windows are defined as five days $(-2$ to +2$)$ around the announcements of management forecasts and earnings. To test the sensitivity of our results to window-specification, we consider two alternative designs. A 3-day window centered on the forecast announcement date and earnings announcement date, one day prior (day -1$)$ to one day after $($ day +1$)$ the announcement dates, results in slightly less significant, but substantially unchanged results (untabulated). In Stage 1, the difference in market reaction at the management earnings forecast (FCAR) is smaller $(0.655 \%)$ and slightly less significant $(t=-3.19)$. In Stage 2, regression $(2 a)$, the coefficients on the overoptimism variable are considerably lower but their significance changes only slightly $\left(1 \phi: \beta_{1}=+1.44, p=0.040 ; 2 \phi: \beta_{1}=+1.10, p=0.049\right.$, one-tailed). In regression $(2 b)$, the coefficients on the variable of interest (the interaction term of overoptimism and the small forecast error indicator) are also considerably lower with slightly lower significance levels $\left(1 \phi: \gamma_{3}=+1.22, p=0.064 ; 2 \phi: \gamma_{3}=+1.21, p=0.028\right.$, one-tailed).

A 3-day window measured from the management forecast announcement date and earnings announcement date (day 0) to two days after the announcement dates (day +2 ) also result in slightly less significant, but substantially unchanged results. In Stage 1, 


\section{CHAPTER 2 \\ Market Reaction to Higher Earnings Management Incentives Implicit in the Earnings Forecasts of Overoptimistic CEOs}

the difference in market reaction at the management earnings forecast (FCAR) is slightly smaller $(0.626 \%)$ and less significant $(t=-3.06)$. In Stage 2, regression $(2 \mathrm{a})$, the coefficients on the overoptimism variable are lower and less significant $\left(1 \notin: \beta_{1}=+1.22\right.$, $\mathrm{p}=0.073 ; 2 \phi: \beta_{1}=+0.89, \mathrm{p}=0.085$, one-tailed). In regression $(2 \mathrm{~b})$, the coefficients on the variable of interest (the interaction term between overoptimism and the small forecast error indicator) are slightly lower, their significance decreases but are still significant (1ф: $\gamma_{3}=+1.04, p=0.094 ; 2 \phi: \gamma_{3}=+1.00, p=0.053$, one-tailed). In sum, alternative event window specifications do not change our inferences.

\subsection{Conclusion}

We examine whether investors recognize and rationally impound into the share price the possible earnings management of overoptimistic CEOs at the time the management forecast is issued, rather than the inferred (actual) earnings management at the announcement of realized earnings. We argue that because managers' own forecasts also become an earnings target, the more optimistic forecasts of overoptimistic managers give additional incentives to these managers to meet or beat their forecasts. We expect that investors, recognizing CEO overoptimism, also recognize the higher earnings management incentives of overoptimistic CEOs and impound these incentives into the share price by discounting the overoptimistic management forecasts compared to those of non-optimistic managers when the forecast is issued.

Because the underreaction by investors to overoptimistic management forecasts has an alternative explanation, i.e., lower credibility of biased forecasts, confirming the underreaction to forecasts issued by overoptimistic CEOs at the forecast date does not answer our research question. Instead, we examine the market reaction at the earnings announcement date to validate our hypothesis. We expect a differential market reaction to earnings announcements of overoptimistic managers compared to those of nonoptimistic managers, if the market has already impounded the higher earnings management incentives of overoptimistic managers at the forecast date. Rational investors react to new information when earnings are announced. Therefore if earnings 


\section{CHAPTER 2 \\ Market Reaction to Higher Earnings Management Incentives Implicit in the Earnings Forecasts of Overoptimistic CEOs}

management incentives of overoptimistic managers have already been impounded into the share price at the forecast date, there will be no market reaction to inferred earnings management (i.e., small positive forecast errors) at the earnings announcement date. In contrast, there will be a positive market reaction to small negative forecast errors of overoptimistic managers, since due to an inferred lack of earnings management a correction of the share price will take place. If, however, investors have not incorporated higher earnings management incentives of overoptimistic managers into the share price when the management forecast is issued, the market reaction to earnings announcements will be similar across overoptimistic and non-optimistic managers.

We indeed find that the market reacts more positively to the earnings announcements of overoptimistic CEOs in the small forecast error range compared to those of non-optimistic managers at the earnings announcement. Our findings indicate that investors react negatively to the higher earnings management incentives of overoptimistic managers when the management forecast is issued and do not react to inferred earnings management of overoptimistic CEOs and/or react more positively to the inferred lack of earnings management by overoptimistic CEOs compared to nonoptimistic managers when earnings are announced.

Our results are important for two reasons. First, we show that investors are not fooled by overoptimistic forecasts, since the forecasts of overoptimistic managers are discounted by the market. By issuing higher management forecasts, firms managed by overoptimistic CEOs do not enjoy positive abnormal returns compared to firms of nonoveroptimistic managers, at the forecast date. Second, we show that after 2001 investor attitudes to earnings management are so negative that all firms managed by overoptimistic CEOs are punished with a lower share price as early as the management forecast date, i.e., the market reaction is driven by expectations of earnings management when the management forecast is issued rather than actual earnings management when earnings are announced.

Our study contributes to the literature in a number of ways. First, our study contributes to the literature on market reactions to public disclosures by showing that a managerial cognitive bias is an additional factor in explaining the market reaction to the 


\section{CHAPTER 2 \\ Market Reaction to Higher Earnings Management Incentives Implicit in the Earnings Forecasts of Overoptimistic CEOs}

issuance of management forecasts and the subsequent earnings announcement. Second, we also contribute to the literature on cognitive biases by separating overoptimism from overconfidence in an empirical setting. While in the management forecasting context forecast accuracy proxies for overconfidence, we examine consequences of CEO overoptimism by not only considering the size of the forecast error but also its sign. In addition, while prior research focused on the market reaction to overconfident forecasts at the announcement of the forecast (Hilary and Hsu, 2011), we show that the market recognizes overoptimism and the associated incentives to manage earnings and incorporates this into the share price already at the forecast date. Third, we contribute to the earnings management around thresholds literature by examining whether the market is fooled by earnings management incentives. We show that beyond the three classic earnings thresholds examined in earnings management literature (e.g., Degeorge et al., 1999), management forecasts are also considered an earnings benchmark both by managers and investors. While prior studies show that firms are punished for beating benchmarks at the earnings announcement date after 2001 (e.g., Keung et al., 2010), we show that the discounting depends on the extent to which the market already incorporated the incentives to manage earnings early on. 




\section{The Effect of Management Forecasts on Information Asymmetry Among Investors ${ }^{10}$}

${ }^{10}$ I am grateful to Gilles Hilary at INSEAD, for a visiting scholarship. I appreciate comments by Thomas Keusch, Frank Moers, Annelies Renders, and workshop participants at Maastricht University. 


\begin{abstract}
This study examines the effect of management earnings forecasts on the information asymmetry among investors around public disclosures. Researchers increasingly agree that information asymmetry among investors also affects firms' cost of capital, but evidence on the effect of management forecasts, although they are pervasive and value relevant corporate voluntary disclosures, on information asymmetry among investors is scant. Using excess trading volumes as a proxy for information asymmetry among investors, I find that in isolation, management forecasts generate higher information asymmetry among investors than earnings announcements. However, investors of forecasting firms face less information asymmetry at the earnings announcement. I conclude that by providing more public disclosure, forecasting firms increase the overall information asymmetry among their investors compared to non-forecasting firms, because the increased information asymmetry at the management forecast is not compensated fully by reduced information asymmetry at the earnings announcement. These results imply that while more voluntary disclosure decreases information asymmetry between the firm and its investors as a whole, it may have unintended consequences by increasing the information asymmetry among investors.
\end{abstract}




\section{CHAPTER 3}

The Effect of Management Forecasts on Information Asymmetry Among Investors

\subsection{Introduction}

This study examines the effect of voluntary management earnings forecasts on the information asymmetry among investors around public disclosures. This research question is motivated by the growing significance of information asymmetry among investors and the increasing importance of management forecasts to capital market participants. Regulators have long been concerned with the integrity of capital markets and the protection of investors. ${ }^{11}$ Regulatory focus is increasingly on leveling the playing field and reducing the informational disadvantages of retail investors. ${ }^{12}$ Traditionally, research has focused on the information asymmetry between the firm and its shareholders and has shown that more (voluntary) disclosure reduces valuation problems by decreasing the information asymmetry between the firm and its investors (Healy and Palepu, 1993; Bamber et al., 2011). In addition to the increasing regulatory concern, however, there is growing evidence that the information asymmetry among investors may also adversely affect a firm's cost of capital (e.g., Botosan and Plumlee, 2002; Botosan et al., 2004; Barron et al., 2005).

Parallel to the growing significance of information asymmetry among investors to market participants, management forecasts have also become a key corporate disclosure mechanism. Studies show that since the passage of the Private Securities Litigation Reform Act (U.S. Congress, 1995), management forecasts have become pervasive in US capital markets (Kile, 1998; Anilowski et al., 2007; Rogers and Van Buskirk, 2013). Management forecasts are not only widespread, they have been documented to be value relevant: more than half of accounting based information is

${ }^{11}$ The AICPA study group (AICPA, 1973:17) has noted early on that "[a]n objective of financial statements is to serve primarily those users who have limited authority, ability or resources to obtain information." Furthermore, the mission of the Securities and Exchange Commission's (SEC) includes the protection of investors and the maintenance of fair capital markets (Foster 1986:40; Hand and Beatty 1992; SEC, 2013).

12 Regulation Fair Disclosure was introduced by the SEC to limit disclosure practices that discriminate across classes of investors (SEC, 2000). The SEC has formed the Investor Advisory Committee (IAC) to promote investor confidence and the integrity of the securities market place (SEC, 2009). Moreover, SEC Chairman Mary L. Schapiro has said that "[u]nderstanding the needs of investors is critical to carrying out the Commission's investor protection mission" (SEC, 2012). 


\section{CHAPTER 3}

The Effect of Management Forecasts on Information Asymmetry Among Investors

provided to investors through management forecasts (Ball and Shivakumar, 2008; Hirst et al., 2008; Beyer et al., 2010). Although the characteristics of voluntary disclosures suggest that they may be associated with differential information asymmetry among investors compared to mandatory disclosures, empirical research has almost exclusively examined information asymmetry among investors around earnings announcements, and hence empirical evidence relating to the effect of voluntary disclosures on information asymmetry among investors is scant.

The information asymmetry among investors around earnings announcements has been studied extensively. Trading volume research finds that earnings announcements induce trading volume reactions as a result of information asymmetry among investors, caused by either differential private information acquisition prior to the announcement or differential private information conveyed by the announcement. In other words, these findings suggest that mandatory disclosures increase the information asymmetry among investors at the time of the disclosure (e.g., Bamber et al., 1997; Bamber et al., 1999; Barron et al., 2002; Barron et al., 2005). In a concurrent study on the trading volume effects of earnings announcements bundled with additional disclosures, Barron et al. (2010) find that earnings announcements issued together with management forecasts generate higher trading volumes and hence higher information asymmetry among investors than unbundled earnings announcements. However, their study does not provide evidence on the incremental effects of management forecasts on the information asymmetry among investors either when the forecast is issued or at the subsequent earnings announcement.

Therefore, in this study I examine the incremental effect of voluntary disclosures, specifically management earnings forecasts, on the information asymmetry among investors. In my analysis I rely on extant trading volume theories suggesting that trading volume is induced by either differential precision of investors' pre-announcement private information (information asymmetry among investors prior to the disclosure) or private event-period information (information asymmetry among investors generated by the disclosure) (Kim and Verrecchia, 1997). In line with the Kim and Verrecchia (1997) theoretical arguments and the research design of recent empirical studies (e.g., Ahmed et 


\section{CHAPTER 3}

The Effect of Management Forecasts on Information Asymmetry Among Investors

al., 2003; Ahmed and Schneible, 2007; Barron et al., 2010), I differentiate between the trading volume effects of pre-announcement private information and event-period private information using the same regression model, where the slope coefficient of the magnitude of contemporaneous price change proxies for the former, and the constant of the regression proxies for the latter. To be able to isolate the effects of management forecasts, I use the unbundled public disclosures of a matched sample of forecasting and non-forecasting firms. I first compare the trading volume effects of management forecasts with those of earnings announcements of non-forecasting firms. Then I compare the trading volume induced by the earnings announcement of forecasting and non-forecasting firms. This method allows me to examine (1) the incremental trading volume effects of management earnings forecasts at the management forecast date, and (2) the effect of management forecasts on the trading volume around the subsequent earnings announcement.

First, I examine excess trading volume reactions associated with both preannouncement and event-period private information at the management forecast date, using the trading volume reaction of non-forecasting firms at the earnings announcement as a benchmark. I find that, in isolation, voluntary management forecasts generate higher information asymmetry among investors than mandatory earnings announcements, as evidenced by higher excess trading volume reactions associated with both preannouncement and event-period private information at the management forecast date compared to the trading volume reaction of non-forecasting firms at the earnings announcement. This implies that the information asymmetry among investors is higher when the disclosure involves predictions for the future compared to disclosures that confirm past events.

Next, I examine trading volume reactions associated with both the preannouncement and event period information components around the subsequent earnings announcement of forecasting firms, using non-forecasters as a benchmark. I find that earnings announcements of forecasting firms are associated with lower information asymmetry among investors than earnings announcements of non-forecasters since the excess trading volume reactions at the earnings announcement date associated with pre- 


\section{CHAPTER 3}

The Effect of Management Forecasts on Information Asymmetry Among Investors

announcement private information are lower, while those associated with event-period private information are not different across forecasters and non-forecasters.

Aggregating the trading volume effects of management forecasts from around the forecast issue and the subsequent earnings announcement, I conclude that investors of forecasting firms face a larger overall information asymmetry than investors of nonforecasting firms as a result of the event-period information component. Taking into account the volume effects at both the forecast and earnings announcement date, the aggregate information asymmetry associated with pre-announcement information is not different between forecasting and non-forecasting firms, since the higher trading volume reaction for forecasters at the forecast date is fully compensated by a lower trading volume at the earnings announcement date. This implies that the better informed investors of forecasting firms have a larger informational advantage at the forecast date, but this is 'used up' in trading and does not carry over to the earnings announcement, where the prior informational disadvantage of less informed investors is significantly reduced and is even fully compensated. In contrast, the aggregate information asymmetry associated with event-period information is higher for forecasters compared to non-forecasters because the information asymmetry generated by forecasting firms' earnings announcement is not different from that of non-forecasting firms, and hence the higher trading volume reaction at the management forecast date is not compensated by a lower trading volume reaction at the earnings announcement. This suggests that on average a management forecast generates the same level of disagreement among investors as an earnings announcement, and moreover, that on average management forecasts do not help in the processing of the subsequent earnings announcement.

Overall my findings indicate that rather than leveling the informational playing field among investors, the voluntary disclosure of management forecasts contributes to increasing the informational disadvantage of some investors over others. Furthermore, while more voluntary disclosure may decrease information asymmetry between the firm and its investors as a whole, it may have unintended consequences by increasing the information asymmetry among investors and thus weakening the disclosure's positive effects on the firm's cost of capital. 


\section{CHAPTER 3}

The Effect of Management Forecasts on Information Asymmetry Among Investors

In additional analyses, I examine whether the specificity of the management forecast is associated with the observed trading volume effects at the management forecast date and subsequent earnings announcement. I first show that the specificity of the management forecast does not directly influence trading volumes associated with preannouncement private information either at the release of the forecast or at the subsequent earnings announcement. Next I find that more specific forecasts generate less eventperiod private information and hence less information asymmetry at the forecast date, implying that investors rely more on a specific forecast when making their trading decisions. However, more specific forecasts generate more event-period private information at the earnings announcement in line with the argument that investors rely more on a more specific forecast when processing the earnings announcement information. Furthermore, I find that the specificity of the management forecast creates a spillover effect at the earnings announcement, because more precise management forecasts reduce the information asymmetry prior to the earnings announcement and induce lower excess trading volumes associated with differential pre-announcement private information.

In another set of additional analyses, I test if my main results hold in the two periods prior to and following RegFD. If, in line with its aim, Regulation Fair Disclosure (RegFD) has decreased information asymmetry among investors, this may influence whether my main results hold in the post-RegFD period. I find that my main results hold in the post-RegFD period: although the higher pre-announcement information asymmetry of investors of forecasting firms in the pre-RegFD period disappears in the post-RegFD period, due to the additional event-period information component around the management forecast, investors of forecasting firms still face a higher overall information asymmetry in the post-RegFD period.

I contribute to the trading volume literature by analyzing the excess trading volume effects of unbundled management forecasts and provide evidence on how an additional element of firms' disclosure policy affects information asymmetry among investors (Bamber et al., 2011). Prior literature has examined the trading volume effects of earnings announcements (e.g., Bamber et al., 1997; Barron et al., 2005) and earnings 


\section{CHAPTER 3}

The Effect of Management Forecasts on Information Asymmetry Among Investors

announcements bundled with management forecasts (Barron et al., 2010). By using both unbundled management forecasts and unbundled earnings announcements I am able to examine the excess trading volume effects of management forecasts in isolation as well as their incremental effects on earnings announcements. My results confirm the finding of Barron et al. (2010) that bundled earnings announcements are associated with higher trading volume reactions, but I am able to decompose this effect with regard to management forecasts. Examined in isolation, the pre-announcement information component is unlikely to be responsible for the higher volume reaction of announcements bundled with management forecasts because the higher volume reaction at the management forecast is fully compensated by the opposite effect at the earnings announcement. Therefore, the higher volume reaction around bundled announcements is likely to be caused by the event-period information component, which is equally high at the forecast and the earnings announcement of forecasting firms.

I also contribute to the voluntary disclosure literature by investigating the effect of voluntary management earnings forecasts on the information asymmetry among investors. Information asymmetry among investors, in other words an unequal informational playing field, has long been a regulatory concern (e.g., Morse, 1980; Levitt, 1998a, 1998b, 1999). I show that while management forecasts increase information asymmetry among investors at the release of the management forecast, they are associated with lower information asymmetry among investors prior to the earnings announcement and on average do not help in the processing of the information content of the subsequent earnings announcement. My findings also show that the overall effect of voluntary management forecasts on the information asymmetry among investors is negative: total information asymmetry among investors of forecasting firms considering both public disclosures, is higher than for investors of non-forecasting firms. The implications of these findings are that rather than making all investors better informed to an equal degree, more (voluntary) disclosure may increase the informational disadvantage of less wellinformed investors. 


\section{CHAPTER 3}

The Effect of Management Forecasts on Information Asymmetry Among Investors

The paper proceeds as follows. Section 2 provides an overview of relevant theory and develops the hypotheses. Section 3 introduces sample selection procedures and empirical design. Section 4 presents the results of the study and Section 5 concludes.

\subsection{Theory and Hypotheses}

\subsubsection{Trading Volume Research}

Beaver's (1968) seminal paper has introduced trading volume reactions into accounting research. His intuition is that while price reactions reflect changes in the expectations about firm value of the market as a whole, trading volume reactions reflect investor disagreement about the value of firms. Since then a rich body of trading volume theory has been produced, which generally supports Beaver's intuition, and posits that trade is caused by differential belief revisions of investors, where the disagreement among investors is induced either by the differential prior precision of private information or differential information processing (Bamber et al., 2011).

Kim and Verrecchia (1997) introduce a comprehensive trading volume model where different types of private information may trigger differential belief revision and hence stimulate informational trade. ${ }^{13}$ Informational trade may be caused by both (1) preannouncement information and (2) event-period information. Pre-announcement information means private information acquired in anticipation of a public disclosure. Pre-announcement information can be used prior to the disclosure (and also subsequently if not subsumed by the announcement itself) and represents the theoretical propositions about differential belief revision caused by differential pre-announcement beliefs, or, in other words, informational differences among investors in the precision of their private information prior to the disclosure. Event-period information is private information

13 Trading volume around a public disclosure encompasses informational trade and noninformational trade (Bamber et al., 2011). Informational trade is caused by the public disclosure, while non-informational or liquidity trade may arise for reasons such as balancing income and idiosyncratic consumption preferences, and portfolio rebalancing (Karpoff, 1986; Bamber et al., 1997). Liquidity trade occurs even when no public information is released. 


\section{CHAPTER 3}

The Effect of Management Forecasts on Information Asymmetry Among Investors

conveyed by the announcement that can only be used in the event period, in conjunction with the announcement itself. Event-period information incorporates the theoretical propositions of differential belief revision induced by differential interpretation of the information conveyed by the announcement that spurs informational trade if the disclosure enables the use of investors' private information in the event-period in conjunction with the disclosure itself (Holthausen and Verrecchia, 1990; Kim and Verrecchia, 1997).

The comprehensive theory hence predicts that (1) a larger differential precision of pre-announcement information induces a higher trading volume reaction to the disclosure, and (2) the amount of event-period information generated by a public disclosure is dependent on the differential interpretation by investors. The larger the differential precision of pre-announcement information, the larger the information asymmetry among investors prior to the announcement, and the higher the trading volume reaction induced by the disclosure. Similarly, the more disagreement the disclosure causes among investors, the more event-period private information generated by the disclosure and the higher the trading volume reaction induced by the disclosure.

Extant trading volume theories do not differentiate between the volume effects of mandatory and voluntary disclosures, but model the volume reactions caused by public disclosures in general. ${ }^{14}$ However, empirical trading volume research has almost exclusively examined the trading volume reactions of earnings announcements. Empirical research examining earnings announcements finds that these announcements generate excess trading volume reaction associated with both pre-announcement and event-period private information. In other words, earnings announcements motivate the acquisition of private information and on average increase information asymmetry among investors, inducing excess trading volume around the disclosure (e.g., Barron et al., 2005).

To the best of my knowledge, there are only two studies that examine the relationship between management forecasts and trading volumes. Based on a sample of

\footnotetext{
${ }^{14}$ Although some theories use earnings announcements as illustration (e.g., Kim and Verrecchia, 1994; Kim and Verrecchia, 1997), these theories are argued to be "sufficiently broad" to generalize to other types of disclosures (Kim and Verrecchia, 1994:42).
} 


\section{CHAPTER 3}

The Effect of Management Forecasts on Information Asymmetry Among Investors

74 annual management forecasts from 1971 to 1973, Nichols et al. (1979) find a significant increase in trading during the week of the management forecast, but no differential reaction based on forecast horizon or the magnitude of the predicted earnings change. Barron et al. (2010) analyze the trading volume effects of earnings announcements that are issued together with additional voluntary disclosures, including management earnings forecasts. Their findings show that earnings announcements bundled with management forecasts induce higher trading volumes than unbundled earnings announcements through both a higher pre-announcement information component and a higher event-period information component. The higher trading volume induced by bundled announcements is consistent with the argument that the earnings announcements of forecasting firms lead to more private information acquisition and convey more private information, resulting in more information asymmetry than those of non-forecasting firms. However, this finding is also consistent with the argument that the earnings announcements of forecasting firms lead to less private information acquisition and generate less private information than those of non-forecasting firms, but this effect is obscured by the additional volume reaction created by the management forecast that relates to a different fiscal period but is announced at the same time. Hence, by examining bundled announcements that combine mandatory and voluntary disclosures relating to different fiscal periods, the study by Barron et al. (2010) is neither able to isolate the volume effects of management forecasts and earnings announcements, nor can it identify the incremental effect of management forecasts on the information acquisition prior to the subsequent earnings announcement and on the processing of the earnings information contained in the subsequent earnings announcement relating to the same fiscal period.

\subsubsection{Management Forecasts}

Examining the management forecast in isolation, i.e. examining the incremental effects of the forecast, and hence, the unbundling of management forecasts and earnings announcement is important since accounting research has established that management forecasts are value relevant (Patell, 1976, Penman, 1980) and that their importance for investors' price discovery has steadily increased over time. Recent research shows that 


\section{CHAPTER 3}

The Effect of Management Forecasts on Information Asymmetry Among Investors

management forecasts contain twice the amount of earnings information compared to earnings announcements (Ball and Shivakumar, 2008; Beyer et al., 2010). The higher value relevance of management forecasts compared to earnings announcement is explained by the different characteristics of management forecasts (Ball and Shivakumar, 2008). Management earnings forecasts, similarly to earnings announcements, are corporate public disclosures but they differ from earnings announcements in their attributes: management forecasts contain forward-looking and more timely information, while earnings announcements are backward-looking, confirmatory, and have a disciplining aspect relating to prior voluntary disclosures (Ball and Shivakumar, 2008).

\subsubsection{Hypothesis Development}

\section{Information Asymmetry around Management Forecasts}

The different characteristics of management forecasts and earnings announcements suggest that the two types of disclosures likely lead to different levels of information asymmetry among investors both prior to and at the public disclosure. As a result, both the level of pre-announcement information precision prior to, and the amount of private event-period information generated by the management forecast are likely to differ from those of the earnings announcement.

Trading volume theories posit that public disclosures motivate investors to acquire private information in anticipation of disclosures (e.g. Kim and Verrecchia 1994, 1997). This implies that the more disclosures a firm makes, the more private information investors generate in anticipation. If management forecasts and earnings announcements had similar characteristics, they would motivate the acquisition of private information to a similar degree, and volume reactions caused by differential prior precision of preannouncement information at the management forecast date for forecasting firms and at the earnings announcement date for non-forecasting firms would be similar.

Similarly, informational trade that is not related to the pre-announcement component of investors' information set is induced if the disclosure enables the use of investors' private information in the event-period in conjunction with the disclosure itself 


\section{CHAPTER 3}

The Effect of Management Forecasts on Information Asymmetry Among Investors

(Kim and Verrecchia, 1997). Empirical volume research shows that earnings announcements generate private event-period information and therefore, increase information asymmetry among investors (e.g., Barron et al., 2005). If management forecasts and earnings announcements had similar attributes, they would generate a similar level of disagreement and a similar amount of private event-period information, and hence would spur a similar volume reaction at the management forecast date for forecasting firms and at the earnings announcement date for non-forecasting firms.

In contrast, because management forecasts have different attributes compared to earnings announcements, both the amount of private information acquisition prior to the release of the management forecast, and the amount of event-period private information generation are likely to be different compared to an earnings announcement (for nonforecasting firms). However, which attributes of management forecast matter more in determining the motivation to search for private information and in the generation of event-period private information, and whether these different attributes intensify or weaken private information search activities prior to a management forecast and, similarly, whether they increase or decrease the amount of private information generated by a management forecast compared to an earnings announcement, is unclear. Whether the trading volume reaction associated with pre-announcement private information is higher at a management forecast or at the earnings announcement (for non-forecasting firms), and in turn, whether the trading volume reaction associated with event-period private information is higher at a management forecast or at the earnings announcement (for non-forecasting firms) is therefore, an empirical question, leading to the following hypotheses:

H1a: The differential prior precision of investors' private information differs between management forecasts for forecasting firms and earnings announcements for non-forecasting firms. 


\section{CHAPTER 3}

The Effect of Management Forecasts on Information Asymmetry Among Investors

$\mathrm{H} 1 \mathrm{~b}$ : The amount of event-period private information generated by the management forecast for forecasting firms and the earnings announcement for non-forecasting firms is different.

\section{Information Asymmetry around Earnings Announcements}

Management forecasts and earnings announcements are corporate public disclosures about the earnings of the same fiscal period of the firm but at two different dates. Therefore, it is possible that the additional earnings information released at the management forecast date influences both investors' private information acquisition prior to the earnings announcement and the generation of event-period information at the earnings announcement.

\section{Pre-announcement Private Information}

As explained above, extant trading volume theories imply that the more disclosures there are for a firm, the more private information investors acquire in anticipation (e.g., Kim and Verrecchia 1994, 1997). If a management forecast, as an additional public disclosure, simply increased the number of trading opportunities for investors and the different attributes of management forecasts had no incremental effects, the theoretical expectation would be that the trading volume reaction to pre-announcement private information around earnings announcements of forecasting and non-forecasting firms would be the same. Cuijpers and Peek (2010) however find empirically that an increase in the frequency of firms' earnings announcement reporting reduces the pre-announcement information asymmetry among investors, implying that an increase in the frequency of public disclosure of earnings information reduces investors' motivation to acquire private information. Investors' motivation to acquire private information following the release of the management forecast but prior to the earnings announcement date may be influenced by the different attributes of management forecasts and the fact that management earnings forecasts predict earnings that are announced at a subsequent mandatory earnings announcement may cause the information asymmetry among investors prior to the 


\section{CHAPTER 3}

\section{The Effect of Management Forecasts on Information Asymmetry Among Investors}

earnings announcement to be different for investors of forecasters compared to investors of non-forecasting firms.

Although, how the attributes of management forecasts influence investors' motivation to search for private information prior to the earnings announcement, is unclear, taking into account the empirical finding related to the effect of reporting frequency on trading volumes I set the following hypothesis:

H2a: $\quad$ The differential precision of investors' private information prior to the earnings announcement is lower for forecasting firms compared to non-forecasting firms.

\section{Event-period Private Information}

Because voluntary management forecasts predict earnings that are announced at the subsequent mandatory earnings announcement, management forecasts that relate to the same fiscal period as the earnings announcement are likely to influence the amount of private information generated by the earnings announcement. But it is unclear how the different attributes of management forecasts affect the private information generated by the earnings announcement, i.e. whether management forecasts convey earnings information that facilitates or hinders the processing of earnings information contained in the earnings announcement.

Therefore, whether management forecasts convey information that is useful in the processing of earnings announcements, and hence whether they increase or decrease disagreement and information asymmetry among investors at the earnings announcement, is ultimately an empirical question, leading to the following hypothesis:

$\mathrm{H} 2 \mathrm{~b}$ : The amount of private event-period information generated by the earnings announcement differs between forecasting and nonforecasting firms. 


\subsection{Sample and Empirical Design}

\subsubsection{Sample}

To test my hypotheses, I require a sample of forecasting and non-forecasting firms. To develop the sample of forecasting firms, I use the First Call Company Issued Guidance (FCCIG) database to obtain a sample of quarterly US management earnings forecasts of earnings per common share (EPS), issued for the fiscal years 1995 to 2011. I drop forecasts issued on or after the fiscal-year end to exclude earnings pre-announcements, earnings warnings and forecasts with erroneous forecast dates. I keep only forecasts where the firm issued one quarterly forecast in the quarter. I eliminate bundled forecasts, i.e. all quarterly forecasts where an annual management forecast and an earnings announcement is issued on the same day. I match the FCCIG sample with First Call Actuals for the quarterly earnings announcement date and the annual earnings number. Then I match the sample with First Call Summary to obtain quarterly analyst forecasts at both the management forecast release date and the earnings announcement date. I drop observations with stale consensus analyst forecasts, that is, I require that the consensus analyst forecast outstanding at the public announcements is calculated within 45 days of the announcement.

To develop the sample of non-forecasting firms, I start with the First Call Summary database, match it to the FCCIG database, and keep the firm quarters during the fiscal years 1995 to 2011 if management has not issued a forecast for the same fiscal period. I ensure that I keep firm-quarter observations of non-forecasting firms, i.e., that there are no quarterly or annual management forecasts at or prior to these firm-quarters. I match the sample with First Call Actuals to obtain the quarterly earnings announcement date and the annual earnings figure. I eliminate observations where more than one earnings announcement is made on the same date. I also drop observations if the consensus analyst forecast outstanding at the public announcements is stale, i.e. if it is calculated more than 45 days prior to the announcement. 


\section{CHAPTER 3}

The Effect of Management Forecasts on Information Asymmetry Among Investors

I exclude observations from both samples with insufficient data in the CRSP and Compustat databases needed to compute my variables. The final sample is made up of 1,676 forecasting and 5,910 non-forecasting firms, with 5,441 and 40,791 firm-quarter observations, respectively.

\section{Propensity Score Matching}

My study examines the trading volume effects of forecasting and non-forecasting firms around both the management forecast and earnings announcement date. It is probable that firms' voluntary forecasting choice is associated with firm characteristics that also influence excess trading volumes. I therefore, control for the self-selection bias of firms issuing voluntary earnings forecasts. I use propensity score matching (PSM) to develop a good control sample for my forecasting firm-quarters on which to test my hypotheses. The PSM method allows me to generate a randomized sample in which the attribute of issuing a voluntary management forecast is randomly distributed across the forecasting and non-forecasting sample (Lawrence et al., 2011). This method ensures that differences in observable characteristics between the two samples are reduced.

I use a logit model to estimate firm-quarter specific propensity scores, i.e. the probability that a firm issues a quarterly management forecast in a given quarter. My treatment variable is the quarterly forecasting choice. In the estimation I include observable variables that could influence the excess trading volume, the outcome variable (Rosenbaum and Rubin, 1983; Armstrong et al., 2010). To ensure proper match on the time dimension, I carry out the matching exercise separately for each year-quarter in my sample. Using the propensity scores I match forecasting and non-forecasting firm-quarter observations, one-on-one, without replacement, using common support, with the smallest propensity score difference. To ensure successful matching I examine the covariate balance between the two samples. 


\section{CHAPTER 3}

The Effect of Management Forecasts on Information Asymmetry Among Investors

The model to estimate the propensity score takes the following form (firm and time subscripts are suppressed):

$$
\mathrm{MEF}=\beta_{0}+\beta_{1} \text { Matching variables }+\varepsilon
$$

Where:

MEF is the outcome variable. It is an indicator variable, equal to one if the firm has issued a quarterly management earnings forecast, and zero otherwise.

Matching variables: Following Barron et al. (2010) and Hribar and Yang (2011), I use the following variables to control for firms' choice of issuing a management forecast: LOSS is an indicator variable, equal to one if the firm reports a loss in the fiscal quarter. Return on assets, ROA, is measured as quarterly net income divided by total assets. Firm size, SIZE, is calculated as share price times outstanding shares five days prior to the event window. The market-to-book ratio, MB, is calculated as the ratio of market-to-book value of the firm's common equity at the end of the fiscal quarter. The number of analyst forecasts, COUNT, is the number of analyst forecasts outstanding at the quarterly earnings announcement. Standard deviation of analyst forecasts, STDEV, is calculated as the standard deviation of analyst forecasts outstanding at the quarterly earnings announcement. Range of analyst forecasts, RANGE, is the absolute difference between the highest and lowest analyst forecast outstanding prior to the quarterly earnings announcement, scaled by the mean analyst forecast. Stock return volatility, RETVOL, is calculated as the standard deviation of daily stock returns over the 253 trading days prior to the quarterly earnings announcement. High-tech industries, HTECH, is an indicator variable equal to one if the firm is member of an industry with the following four-digit sic codes: 2833-2836 (Drugs), 8731-8734 (R\&D Services), 7371-7379 (Software), 35703577 (Computers), 3600-3674 (Electronics), 3810-3845 (Instruments), and zero otherwise. The variable AUD is an indicator variable equal to one if the firm is audited by one of the "Big4" auditing firms, and zero otherwise. Leverage, LEV, is calculated as total debt over total assets in the quarter. Issue of shares, ISSUE, is an indicator variable, equal to one if the firm has issued shares in the quarter. Acquisition, ACQ, is an indicator 


\section{CHAPTER 3}

The Effect of Management Forecasts on Information Asymmetry Among Investors

variable, equal to one if the firm has reported mergers \& acquisitions activities in excess of $10 \%$ of total assets in the quarter. Audit opinion, $\mathrm{AO}$, is an indicator variable equal to one if the firm has received a qualified or adverse audit opinion in the fiscal year, and zero otherwise. Weakness, WEAK, is an indicator variable equal to one if the firm has reported an internal control material weakness in the fiscal year, and zero otherwise. Institutional ownership, INST, is calculated as the percentage of outstanding shares held by institutional investors in the quarter. I also include industry fixed effects based on the Fama and French (1997) 48 industry classification but no quarter- and year-fixed effects because of the year-quarter based matching process.

Following the propensity score matching to control for potential selection bias relating to the issue of voluntary management forecasts, my matched sample is made up of 4,651 firm-quarter observations for forecasting and non-forecasting firms, each. ${ }^{15}$

\subsubsection{Empirical Design}

\section{Main Empirical Regression}

Modeling trading volume effects, Kim and Verrecchia (1997) incorporate both preannouncement and event-period private information in their comprehensive excess trading volume model and argue that the inclusion of both private information components in excess trading volume regressions eliminates empirical misspecifications, specifically an omitted variable bias.

Kim and Verrecchia (1997) show that the differential precision of preannouncement private information generates trading volume that has a linear relation to the magnitude of price change. Based on their model the coefficient on the magnitude of contemporaneous price change in the excess trading volume regression is used in recent empirical research to empirically proxy for the pre-announcement information component of volume reactions (Bamber et al., 2011, e.g., Ahmed et al., 2003; Ahmed and Schneible, 2007; Barron et al., 2010).

${ }^{15}$ All results of hypotheses tests are robust to restricting the sample to matched observations with a propensity score less than 0.01 . 


\section{CHAPTER 3}

The Effect of Management Forecasts on Information Asymmetry Among Investors

Kim and Verrecchia (1997) show that the information asymmetry generated by a public disclosure, i.e. private event-period information, induces trading volume that is independent of the magnitude of contemporaneous price change. This suggests that the empirical proxy of event-period information is the constant in the excess trading volume regression after controlling for the magnitude of contemporaneous price change. Relying on this argument recent empirical studies employ the constant as the empirical proxy for the event-period information component of volume reactions (Bamber et al., 2011:433, e.g., Ahmed et al., 2003; Ahmed and Schneible, 2007; Barron et al., 2010).

Therefore, to measure the trading volume effect of both pre-announcement private information and event-period private information and to test my hypotheses, I estimate the following empirical model:

$$
\text { EXVOL }=\beta_{0}+\beta_{1} \text { LARET }+ \text { Control variables }+\varepsilon
$$

Where:

EXVOL is excess trading volume. It is defined as the natural log of cumulative daily trading volume (number of shares traded over the number of shares outstanding) over the three-day event window centered on the day of the quarterly public announcement (management forecast or earnings announcement), less the natural log of the firm-specific annual median trading volume. Median trading volume is the median volume for contiguous three-day periods over the 249 trading days prior to the earnings announcement event window. This share turnover measure is expected to control for firm size and the fact that the number of shares outstanding and the number of shares traded have both grown steadily over time (Bamber et al., 2011).

LARET is the magnitude of contemporaneous price change, defined as the natural $\log$ of the absolute value of the sum of the firm's daily returns over the three-day event window. This proxy is used to measure the trading volume effects related to differential prior precision of pre-announcement information.

Control variables: I include the control variables introduced by Barron et al. (2010), to control for firm and announcement characteristics that are likely to be 


\section{CHAPTER 3}

The Effect of Management Forecasts on Information Asymmetry Among Investors

associated with market reaction around the announcement. Quarterly earnings surprise, SURP, is calculated as the absolute value of the difference between the actual earnings per share and the consensus analyst earnings forecast outstanding on the day of the announcement, scaled by the share price. Sign of the earnings surprise, SIGN, is an indicator variable, equal to one if earnings surprise, SURP, is negative, and zero otherwise. Firm size, SIZE, is included to control for firms' information environment. It is calculated as share price times outstanding shares five days prior to the event window. The market-to-book ratio, denoted MB, is calculated as the ratio of market-to-book value of the firm's common equity at the end of the fiscal quarter and is used to control for firms' growth opportunities. I also include indicator variables for quarters and years to control for time-series trends in trading volumes.

In line with the Kim and Verrecchia (1997) theoretical arguments and the empirical specification of recent empirical studies, I use Model (2) to differentiate between the trading volume effect of pre-announcement private information and eventperiod private information. I expect $\beta_{1}$, the coefficient on the magnitude of contemporaneous price change, LARET, to be positive, because the magnitude of price change is positively associated with trading volume (e.g. Bamber et al., 1997; Barron et al., 2005). In the presence of event-period information I expect a positive sign on $\beta_{0}$, the constant of Model (2). Prior empirical research finds that SIZE is negatively associated with trading volume (e.g. Bamber, 1986; Bamber et al., 1997; Barron et al., 2005), therefore, I expect a negative coefficient on SIZE.

\section{Information Asymmetry around Management Forecasts}

Hypotheses $1 \mathrm{a}$ and $1 \mathrm{~b}$ examine the information asymmetry among investors associated with management forecasts in isolation. To measure the incremental trading volume effects of management forecasts, I compare the trading volume effects of forecasting firms at the release of the management forecast with the trading volume effects of nonforecasting firms at the earnings announcement. I use a matched sample of forecasting and non-forecasting firms, employing the trading volume effects of non-forecasting firms at the earnings announcement as a benchmark. 


\section{CHAPTER 3}

The Effect of Management Forecasts on Information Asymmetry Among Investors

Hypothesis 1a compares the differential precision of investors' private information prior to the management forecast with that prior to the earnings announcement of non-forecasting firms, while Hypothesis $1 \mathrm{~b}$ compares the private eventperiod information generated by management forecast with the event-period information generated by the earnings announcement of non-forecasting firms.

To test Hypotheses 1a and 1b, I first estimate Model (2) separately for the sample of forecasting firms at the management forecast date and the sample of non-forecasting firms at the earnings announcement date. Then I compare the significance and sign of both the coefficient on LARET, $\left(\beta_{1}\right)$, and the constant, $\left(\beta_{0}\right)$, across the two regressions.

If the management forecast motivates the acquisition of more private information prior to the disclosure than the earnings announcement, the coefficient on LARET, $\left(\beta_{1}\right)$, in the regression at the management forecast date (for forecasting firms) will be higher than in the regression at the earnings announcement date (for nonforecasting firms). Similarly, if the earnings information provided by the management forecast generates more private event-period information than the earnings announcement, the constant, $\left(\beta_{0}\right)$, in the regression around the management forecast date (for forecasting firms) will be higher than in the regression around the earnings announcement (for non-forecasting firms).

\section{Information Asymmetry around Earnings Announcements}

Hypotheses $2 \mathrm{a}$ and $2 \mathrm{~b}$ examine how the management forecast influences the information asymmetry among investors around the earnings announcement. Therefore, I compare the trading volume effects of forecasting firms with those of non-forecasting firms at the earnings announcement. I investigate the influence of the management forecast on trading volumes at the earnings announcement using my matched sample of forecasting and nonforecasting firms and employing the trading volume effects of non-forecasting firms at the earnings announcement as a benchmark.

Hypothesis 2 a tests the difference between the differential precision of investors' private information prior to the earnings announcement of forecasting and nonforecasting firms, while Hypothesis $2 b$ tests the difference between the event period 


\section{CHAPTER 3}

\section{The Effect of Management Forecasts on Information Asymmetry Among Investors}

private information generated by the earnings announcement of forecasting compared to non-forecasting firms.

To test Hypotheses 2a and 2b, I first reestimate Model (2) separately for the forecasting and non-forecasting samples around the earnings announcement date. Then, as before, I compare the significance and sign of both the coefficient on LARET, $\left(\beta_{1}\right)$, and the constant, $\left(\beta_{0}\right)$, between the forecasting and non-forecasting firm regressions.

If the management forecast motivates investors of forecasting firms to acquire more private information compared to investors of non-forecasting firms prior to the earnings announcement, the coefficient on LARET, $\left(\beta_{1}\right)$, at the earnings announcement date in the forecasting firm regression will be higher than the coefficient in the nonforecasting firm regression. Similarly, if the information provided by the management forecast helps in processing the information conveyed by the earnings announcement, the constant, $\left(\beta_{0}\right)$, in the forecasting firm regression will be lower than the constant in the non-forecasting firm regression.

\section{Empirical Specification Related to Inferences from the Constant}

In the tests of Hypotheses $1 \mathrm{~b}$ and $2 \mathrm{~b}$ my empirical proxy for the presence of event-period private information is the constant. In addition to the event-period information component, however, the constant of a multiple regression "impounds effects of model misspecification such as omitted variables and nonlinearities" (Bamber et al., 2011:450), and furthermore it includes the benchmark for all indicator variables and other fixed effects. This poses two potential challenges for the interpretation of my results. First, it inhibits drawing conclusions about the value of the constant with regard to my variable of interest. Because I only draw conclusions from the relative and not the absolute values of the variables in the three regressions, this constraint does not pose practical problems in this study. Second, I include quarter and year indicator variables in my empirical models to control for time trends in trading volumes. Because there are significant variations in the level of trading volume over time in my sample, the choice of the benchmark year affects the constant and hence potentially my inferences. Therefore, I run my empirical regressions on the whole sample 17 times (the number of years in my 


\section{CHAPTER 3}

\section{The Effect of Management Forecasts on Information Asymmetry Among Investors}

sample period), but vary the benchmark year. Then, I report results based on a representative regression (using the first year, 1995 as a benchmark) but include inferences from coefficient comparisons of each of the 17 regressions.

\section{Overall Information Asymmetry}

To assess the overall effect of management forecasts on information asymmetry related to both the differential prior precision of pre-announcement private information and the event-period private information components, I compare the findings from testing all the hypotheses. To facilitate the comparison I pool the observations from the three separate regressions and employ the following empirical model:

$$
\begin{gathered}
\text { EXVOL }=\beta_{0}+\beta_{1} \text { LARET }+\beta_{2} \text { FOR }+\beta_{3} \text { FEA }+\beta_{4} \text { FOR } * \text { LARET } \\
+\beta_{5} \text { FEA } * \text { LARET }+ \text { Control variables }+\varepsilon
\end{gathered}
$$

Where:

FOR is an indicator variable for observations of forecasting firms at the management forecast date, while FEA is an indicator variable for observations of forecasting firms at the earnings announcement date.

This specification uses the observations of non-forecasting firms at the earnings announcement date as benchmark, and enables me to make inferences about the overall effect of management forecasts on trading volumes associated with pre-announcement private information and the event-period private information components directly by comparing the coefficients of FOR*LARET $\left(\beta_{4}\right)$ and FEA*LARET $\left(\beta_{5}\right)$, and FOR $\left(\beta_{2}\right)$ and FEA $\left(\beta_{3}\right)$, respectively.

In addition, this specification controls, by construction, for the challenges related to drawing inferences from the constant. In Model (3) I draw inferences about the eventperiod information component generated by earnings announcements from the indicator variables FOR $\left(\beta_{2}\right)$ and FEA $\left(\beta_{3}\right)$ and not the constant of the regression. This treatment is similar to that of Ahmed et al. (2003) and Ahmed and Schneible (2007), who measure the change in differential interpretation generated by earnings announcements between two 


\section{CHAPTER 3}

\section{The Effect of Management Forecasts on Information Asymmetry Among Investors}

time periods. Their main variable of interest is also the indicator variable proxying for observations in the period following a market-wide event or market-wide changes and not the constant.

\subsection{Results}

\subsubsection{Descriptive Statistics}

Table 3.1 Panel A shows that in the unmatched, full sample, forecasting firms are different from non-forecasting firms: they are larger, have a higher analyst following, better performance, and a higher institutional ownership. In terms of volume and price reactions around the earnings announcement the two types of firms are also different: the price reaction around the earnings announcement is significantly higher for forecasting firms, the median trading volume of forecasters over the year preceding the quarterly earnings announcement is also significantly higher. Forecasting firms' excess trading volume and price reaction around the earnings announcement are significantly higher. Table 3.1 Panel $\mathrm{C}$ shows that the distribution of firm-quarter observations is uneven: non-forecasting firm-quarters peak at the beginning of the sample period and decrease during the middle years, forecasting observations peak in the mid-years of the sample period and remain at a high level until the end. Table 3.1 Panel D shows that the distribution of observations across quarters is even for forecasting firms with a peak in the last quarter, while nonforecasting firm-observations peter out in the last quarter.

Table 3.2 Panel A shows that in the matched sample forecasting and nonforecasting firms do not differ on most of the matching variables, although forecasting firms have a higher analyst following and institutional ownership. Table 3.2 Panels C and D show that the distribution of firm-quarter observations is even between forecasting and non-forecasting firms in the matched sample, due to the year and quarter based match. 
CHAPTER 3

The Effect of Management Forecasts on Information Asymmetry Among Investors

Table 3.1 - Descriptive Statistics of Full Sample

\begin{tabular}{|c|c|c|c|c|c|c|c|c|c|c|}
\hline \multicolumn{11}{|c|}{ Panel A - Forecasting and Non-Forecasting Firms at the Earnings Announcement } \\
\hline & \multicolumn{4}{|c|}{ Non-Forecasters } & \multicolumn{4}{|c|}{ Forecasters } & \multicolumn{2}{|c|}{ Test of Mean } \\
\hline & $\mathbf{N}$ & Mean & Median & SD & $\mathbf{N}$ & Mean & Median & SD & tval & pval \\
\hline VOL & 40,791 & 1.517 & 0.344 & 4.648 & 5,441 & 3.119 & 1.310 & 6.570 & -22.59 & 0.000 \\
\hline MEDVOL & 40,791 & 1.575 & 1.000 & 1.787 & 5,441 & 3.065 & 2.255 & 2.791 & -53.42 & 0.000 \\
\hline EXVOL & 40,791 & 0.384 & 0.343 & 0.749 & 5,441 & 0.497 & 0.485 & 0.605 & 10.67 & 0.000 \\
\hline LARET & 40,791 & -3.627 & -3.420 & 1.450 & 5,441 & -3.291 & -3.059 & 1.344 & -16.19 & 0.000 \\
\hline SURP & 1 & 0.026 & 0.00 & 1.4 & 5,441 & 021 & .003. & 0.347 & 26 & 0.794 \\
\hline SIGN & 1 & 0.331 & 0 & & 5,441 & & 1 & & & 0.000 \\
\hline SIZE & 40,791 & 3,172 & 574 & 14,810 & 5,441 & 6,386 & 1,188 & 22,740 & -13.96 & 0.000 \\
\hline MB & 40,791 & 5,215 & 2,024 & 266,142 & 5,441 & 2,876 & 2,129 & 7,664 & 0.64 & 0.517 \\
\hline LOSS & 40 & 0.236 & م & & 5,441 & 43 & 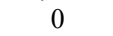 & & -1.14 & 0.254 \\
\hline ROA & 40,791 & -0.003 & 0.00 & 120 & 5,441 & 0.001 & 0.0 & 0.081 & -2.39 & 0.017 \\
\hline STDEV & 40,791 & 0.041 & 0.010 & 0.221 & 5,441 & 0.048 & 0.020 & 0.369 & -1.99 & 0.046 \\
\hline $\mathrm{COU}$ & 1 & 5.720 & 4 & & & & 8 & & -54.02 & 0.000 \\
\hline RANGI & 91 & 0.455 & 0.11 & & 5,441 & 0.676 & 0.250 & 1.692 & -8.07 & 0.000 \\
\hline WEAK & 40,791 & 0.010 & 0 & 02 & 5,441 & 0.018 & 0 & 0.134 & -5.22 & 0.000 \\
\hline INST & 40,791 & 0.420 & 0.426 & & 5,441 & 0.603 & 0.680 & & -44.09 & 0.000 \\
\hline $\mathrm{AO}$ & 1 & 0.000 & . & & 5,4 & 0.000 & 0 & 0.0 & 0.00 & 1.000 \\
\hline ACQ & 4 & 0.070 & 0 & & 5 , & 0.076 & 0 & 0.265 & -1.62 & 0.105 \\
\hline ISSUE & 40,791 & 0.040 & 0 & 0.196 & 5,441 & 0.003 & 0 & 0.0 & 13.86 & 0.000 \\
\hline LEV &, 791 & 0.238 & 0.188 & & 5,441 & 0.182 & 0.155 & & 16.85 & 0.000 \\
\hline AUD & 40,791 & 0.817 & 1 & 0.386 & 5,441 & 0.946 & 1 & 0.225 & 24.11 & 0.000 \\
\hline \multicolumn{11}{|c|}{ Panel B - Forecasters at the Management Forecast and Earnings Announcement } \\
\hline & \multicolumn{4}{|c|}{ Management Forecast } & \multicolumn{4}{|c|}{ Earnings Announcement } & \multicolumn{2}{|c|}{ Test of Mean } \\
\hline & $\mathbf{N}$ & Mean & Median & SD & $\mathbf{N}$ & Mean & Median & SD & & \\
\hline VOL & 5,441 & 4.430 & 1.839 & 8.992 & 5,441 & 3.119 & 1.3 & 6.5 & 8.68 & 0.000 \\
\hline MEDVOL & 5,441 & 3.073 & 2.228 & 2.871 & 5,441 & & 2.255 & & 0.15 & 0.883 \\
\hline EXVOL & 5,441 & 0.689 & 0.607 & 0.688 & 5,441 & 0.497 & 0.485 & 0.605 & 15.46 & 0.000 \\
\hline LARET & 5,441 & -3.047 & -2.868 & 1.300 & 5,441 & -3.291 & -3.059 & 1.344 & 9.63 & 0.000 \\
\hline
\end{tabular}

VOL cumulative daily trading volume over the three-day event window centered on the day of the quarterly earnings announcement one day before the announcement date $($ day -1$)$ to one day after the announcement date $($ day +1$)$, less the natural $\log$ of the firm-specific annual median trading volume. MEDVOL is the median volume for contiguous three-day periods over the 249 trading days prior to the earnings announcement event window. EXVOL is excess trading volume, the natural log of cumulative daily trading volume over the three-day event window centered on the day of the quarterly earnings announcement one day before the announcement date (day -1) to one day after the announcement date (day +1$)$, less the natural log of the firm-specific annual median trading volume. LARET is the magnitude of price change, the natural log of the absolute value of the sum of the firm's daily returns over the three-day event windows. SURP is quarterly earnings surprise, the absolute value of the difference between the actual earnings per share and the consensus analyst earnings forecast outstanding on the day of the announcement, scaled by the share price. SIGN is sign of the earnings surprise, indicator variable, 1 if earnings surprise, SURP, is negative, and 0 otherwise. SIZE is firm size, share price times outstanding shares five days prior to the event window. $\mathrm{MB}$ is the market to book ratio, the ratio of market to book value of the firm's common equity at the beginning of the fiscal year. LOSS is an indicator variable, 1 if the firm reports a loss in the fiscal quarter. ROA is return on assets, quarterly net income divided by total assets. COUNT is the number of analyst forecasts outstanding at the quarterly earnings announcement. STDEV is standard deviation of analyst forecasts, outstanding at the quarterly earnings announcement. RANGE is range of analyst forecasts, the absolute difference between highest and lowest analyst forecast outstanding prior to the quarterly earnings announcement, scaled by the mean analyst forecast. WEAK is an indicator variable, 1 if the firm has reported an internal control material weakness in the fiscal year. INST is institutional ownership, percentage of outstanding shares held by institutional investors in the quarter. AUD is an indicator variable, lif the firm is audited by one of the "Big4" auditing firms. LEV is leverage, total debt over total assets in the quarter. ISSUE is an indicator variable, 1 if the firm has issued shares in the quarter. ACQ is an indicator variable, 1 if the firm has reported mergers \& acquisitions activities in excess of $10 \%$ of total assets in the quarter. $\mathrm{AO}$ is an indicator variable, 1 if the firm has received a qualified or adverse audit opinion in the fiscal year. 
CHAPTER 3

The Effect of Management Forecasts on Information Asymmetry Among Investors

Table 3.1 - Descriptive Statistics of Full Sample (contd)

\begin{tabular}{|c|c|c|c|c|c|c|}
\hline \multicolumn{7}{|c|}{ Panel C - Number of Observations per Fiscal Year } \\
\hline \multirow[t]{2}{*}{ Fiscal year } & \multicolumn{2}{|c|}{ Non-Forecasting } & \multicolumn{2}{|c|}{ Forecasting } & \multicolumn{2}{|c|}{ Full sample } \\
\hline & $\mathrm{N}$ & $\%$ & $\mathrm{~N}$ & $\%$ & $\mathrm{~N}$ & $\%$ \\
\hline 1995 & 4,479 & 10.98 & 128 & 2.35 & 4,607 & 9.96 \\
\hline 1996 & 4,454 & 10.92 & 162 & 2.98 & 4,616 & 9.98 \\
\hline 1997 & 3,917 & 9.60 & 188 & 3.46 & 4,105 & 8.88 \\
\hline 1998 & 3,539 & 8.68 & 312 & 5.73 & 3,851 & 8.33 \\
\hline 1999 & 2,776 & 6.81 & 264 & 4.85 & 3,040 & 6.58 \\
\hline 2000 & 2,311 & 5.67 & 334 & 6.14 & 2,645 & 5.72 \\
\hline 2001 & 1,685 & 4.13 & 584 & 10.73 & 2,269 & 4.91 \\
\hline 2002 & 1,285 & 3.15 & 451 & 8.29 & 1,736 & 3.75 \\
\hline 2003 & 1,308 & 3.21 & 374 & 6.87 & 1,682 & 3.64 \\
\hline 2004 & 1,303 & 3.19 & 424 & 7.79 & 1,727 & 3.74 \\
\hline 2005 & 1,722 & 4.22 & 368 & 6.76 & 2,090 & 4.52 \\
\hline 2006 & 1,897 & 4.65 & 366 & 6.73 & 2,263 & 4.89 \\
\hline 2007 & 2,215 & 5.43 & 279 & 5.13 & 2,494 & 5.39 \\
\hline 2008 & 2,548 & 6.25 & 338 & 6.21 & 2,886 & 6.24 \\
\hline 2009 & 2,600 & 6.37 & 394 & 7.24 & 2,994 & 6.48 \\
\hline 2010 & 2,451 & 6.01 & 374 & 6.87 & 2,825 & 6.11 \\
\hline 2011 & 301 & 0.74 & 101 & 1.86 & 402 & 0.87 \\
\hline Total & 40,791 & 100 & 5,441 & 100 & 46,232 & 100 \\
\hline \multicolumn{7}{|c|}{$\begin{array}{l}\text { Panel D - Number of Observations per Quarter } \\
\text { Fiscal }\end{array}$} \\
\hline & $\mathrm{N}$ & $\%$ & $\mathrm{~N}$ & $\%$ & $\mathrm{~N}$ & $\%$ \\
\hline 1 & 11,544 & 28.30 & 1,367 & 25.12 & 12,911 & 27.93 \\
\hline 2 & 10,223 & 25.06 & 1,362 & 25.03 & 11,585 & 25.06 \\
\hline 3 & 10,288 & 25.22 & 1,302 & 23.93 & 11,590 & 25.07 \\
\hline 4 & 8,736 & 21.42 & 1,410 & 25.91 & 10,146 & 21.95 \\
\hline Total & 40,791 & 100 & 5,441 & 100 & 46,232 & 100 \\
\hline
\end{tabular}


CHAPTER 3

The Effect of Management Forecasts on Information Asymmetry Among Investors

Table 3.2 - Descriptive Statistics of Matched Sample

\begin{tabular}{|c|c|c|c|c|c|c|c|c|c|c|}
\hline \multicolumn{11}{|c|}{ Panel A - Forecasting and Non-Forecasting Firms at the Earnings Announcement } \\
\hline & \multicolumn{4}{|c|}{ Non-Forecasters } & \multicolumn{4}{|c|}{ Forecasters } & \multicolumn{2}{|c|}{ Test of Mean } \\
\hline & $\mathbf{N}$ & Mean & Median & SD & $\mathbf{N}$ & Mean & Median & SD & tval & pval \\
\hline VOL & 4,651 & 2.526 & 0.854 & 5.851 & 4,651 & 3.008 & 1.219 & 6.656 & -3.71 & 0.000 \\
\hline MEDVOL & 4,651 & 2.328 & 1.591 & 2.397 & 4,651 & 2.969 & 2.189 & 2.737 & -12.02 & 0.000 \\
\hline EXVOL & 4,651 & 0.502 & 0.455 & 0.698 & 4,651 & 0.487 & 0.472 & 0.618 & 1.10 & 0.273 \\
\hline LARET & 4,651 & -3.327 & -3.126 & 1.326 & 4,651 & -3.281 & -3.046 & 1.348 & -1.65 & 0.097 \\
\hline SURP & 4,651 & 0.010 & 0.001 & 0.096 & 4,651 & 0.016 & 0.003 & 0.126 & -2.58 & 0.010 \\
\hline SIGN & 4,651 & 0.298 & 0 & 0.457 & & 0.517 & 1 & 0.500 & -22.09 & 0.000 \\
\hline SIZE & 4,651 & 5,535 & 784 & 20,960 & 4,651 & 5,952 & 1,057 & 22,400 & -0.93 & 0.354 \\
\hline $\mathrm{MB}$ & 4,651 & 2,785 & 2,275 & 15,065 & 4,651 & 2,887 & 2,087 & 7,493 & -0.41 & 0.679 \\
\hline LOSS & 4,651 & 0.249 & 0 & 0.432 & 4,651 & 0.246 & 0 & 0.431 & 0.34 & 0.737 \\
\hline ROA & 4,651 & 0.003 & 0.012 & 0.061 & 4,651 & 0.002 & 0.010 & 0.061 & 0.79 & 0.429 \\
\hline STDEV & 4,651 & 0.040 & 0.020 & 0.121 & 4,651 & 0.039 & 0.020 & 0.093 & 0.45 & 0.655 \\
\hline COUNT & 4,651 & 8.117 & 6 & 6.535 & 4,651 & 8.992 & 8 & 5.853 & -6.80 & 0.000 \\
\hline RANGE & 4,651 & 0.593 & 0.167 & 2.210 & 4,651 & 0.620 & 0.250 & 1.428 & -0.70 & 0.484 \\
\hline WEAK & 4,651 & 0.014 & 0 & 0.117 & 4,651 & 0.014 & 0 & 0.118 & - & - \\
\hline INST & 4,651 & 0.554 & 0.607 & 0.290 & 4,651 & 0.591 & 0.667 & 0.287 & -6.18 & 0.000 \\
\hline $\mathrm{AO}$ & 4,651 & 0 & 0 & 0 & 4,651 & 0 & 0 & 0 & - & - \\
\hline ACQ & 4,651 & 0.084 & 0 & 0.277 & 4,651 & 0.080 & 0 & 0.271 & 0.70 & 0.482 \\
\hline ISSUE & 4,651 & 0.004 & 0 & 0.064 & 4,651 & 0.003 & 0 & 0.055 & 0.81 & 0.419 \\
\hline LEV & 4,651 & 0.198 & 0.142 & 0.207 & 4,651 & 0.182 & 0.155 & 0.180 & 3.98 & 0.000 \\
\hline AUD & 4,651 & 0.917 & 1 & 0.276 & 4,651 & 0.940 & 1 & 0.237 & -4.31 & 0.000 \\
\hline \multicolumn{11}{|c|}{ Panel B - Forecasters at the Management Forecast and Earnings Announcement } \\
\hline & \multicolumn{4}{|c|}{ Management Forecast } & \multicolumn{4}{|c|}{ Earnings Announcement } & \multicolumn{2}{|c|}{ Test of Mean } \\
\hline & $\mathbf{N}$ & Mean & Median & SD & $\mathbf{N}$ & Mean & Median & SD & tval & pval \\
\hline VOL & 4,651 & 4.427 & 1.774 & 9.259 & 4,651 & 3.008 & 1.219 & 6.656 & 8.49 & 0.000 \\
\hline MEDVOL & 4,651 & 2.973 & 2.163 & 2.817 & 4,651 & 2.969 & 2.189 & 2.737 & 0.07 & 0.945 \\
\hline EXVOL & 4,651 & 0.695 & 0.609 & 0.706 & 4,651 & 0.487 & 0.472 & 0.618 & 15.12 & 0.000 \\
\hline LARET & 4,651 & -3.029 & -2.838 & 1.310 & 4,651 & -3.281 & -3.046 & 1.348 & 9.14 & 0.000 \\
\hline
\end{tabular}

VOL cumulative daily trading volume over the three-day event window centered on the day of the quarterly earnings announcement one day before the announcement date (day -1$)$ to one day after the announcement date (day +1$)$, less the natural log of the firm-specific annual median trading volume. MEDVOL is the median volume for contiguous three-day periods over the 249 trading days prior to the earnings announcement event window. EXVOL is excess trading volume, the natural $\log$ of cumulative daily trading volume over the three-day event window centered on the day of the quarterly earnings announcement one day before the announcement date (day -1$)$ to one day after the announcement date $($ day +1$)$, less the natural log of the firm-specific annual median trading volume. LARET is the magnitude of price change, the natural $\log$ of the absolute value of the sum of the firm's daily returns over the three-day event windows. SURP is quarterly earnings surprise, the absolute value of the difference between the actual earnings per share and the consensus analyst earnings forecast outstanding on the day of the announcement, scaled by the share price. SIGN is sign of the earnings surprise, indicator variable, 1 if earnings surprise, SURP, is negative, and 0 otherwise. SIZE is firm size, share price times outstanding shares five days prior to the event window. MB is the market to book ratio, the ratio of market to book value of the firm's common equity at the beginning of the fiscal year. LOSS is an indicator variable, 1 if the firm reports a loss in the fiscal quarter. ROA is return on assets, quarterly net income divided by total assets. COUNT is the number of analyst forecasts outstanding at the quarterly earnings announcement. STDEV is standard deviation of analyst forecasts, outstanding at the quarterly earnings announcement. RANGE is range of analyst forecasts, the absolute difference between highest and lowest analyst forecast outstanding prior to the quarterly earnings announcement, scaled by the mean analyst forecast. WEAK is an indicator variable, 1 if the firm has reported an internal control material weakness in the fiscal year. INST is institutional ownership, percentage of outstanding shares held by institutional investors in the quarter. AUD is an indicator variable, lif the firm is audited by one of the "Big4" auditing firms. LEV is leverage, total debt over total assets in the quarter. ISSUE is an indicator variable, 1 if the firm has issued shares in the quarter. ACQ is an indicator variable, 1 if the firm has reported mergers \& acquisitions activities in excess of $10 \%$ of total assets in the quarter. AO is an indicator variable, 1 if the firm has received a qualified or adverse audit opinion in the fiscal year. 
CHAPTER 3

The Effect of Management Forecasts on Information Asymmetry Among Investors

Table 3.2 - Descriptive Statistics of Matched Sample (contd)

\begin{tabular}{|c|c|c|c|c|c|c|}
\hline \multicolumn{7}{|c|}{ Panel C - Number of Observations per Fiscal Year } \\
\hline \multirow[t]{2}{*}{ Fiscal year } & \multicolumn{2}{|c|}{ Non-Forecasting } & \multicolumn{2}{|c|}{ Forecasting } & \multicolumn{2}{|c|}{ Full sample } \\
\hline & $\mathrm{N}$ & $\%$ & $\mathrm{~N}$ & $\%$ & $\mathrm{~N}$ & $\%$ \\
\hline 1995 & 122 & 2.62 & 122 & 2.62 & 244 & 2.62 \\
\hline 1996 & 155 & 3.33 & 155 & 3.33 & 310 & 3.33 \\
\hline 1997 & 181 & 3.89 & 181 & 3.89 & 362 & 3.89 \\
\hline 1998 & 298 & 6.41 & 298 & 6.41 & 596 & 6.41 \\
\hline 1999 & 253 & 5.44 & 253 & 5.44 & 506 & 5.44 \\
\hline 2000 & 312 & 6.71 & 312 & 6.71 & 624 & 6.71 \\
\hline 2001 & 488 & 10.49 & 488 & 10.49 & 976 & 10.49 \\
\hline 2002 & 354 & 7.61 & 354 & 7.61 & 708 & 7.61 \\
\hline 2003 & 302 & 6.49 & 302 & 6.49 & 604 & 6.49 \\
\hline 2004 & 326 & 7.01 & 326 & 7.01 & 652 & 7.01 \\
\hline 2005 & 306 & 6.58 & 306 & 6.58 & 612 & 6.58 \\
\hline 2006 & 274 & 5.89 & 274 & 5.89 & 548 & 5.89 \\
\hline 2007 & 235 & 5.05 & 235 & 5.05 & 470 & 5.05 \\
\hline 2008 & 305 & 6.56 & 305 & 6.56 & 610 & 6.56 \\
\hline 2009 & 353 & 7.59 & 353 & 7.59 & 706 & 7.59 \\
\hline 2010 & 328 & 7.05 & 328 & 7.05 & 656 & 7.05 \\
\hline 2011 & 59 & 1.27 & 59 & 1.27 & 118 & 1.27 \\
\hline Total & 4,651 & 100 & 4,651 & 100 & 9,302 & 100 \\
\hline \multicolumn{7}{|c|}{$\begin{array}{l}\text { Panel D - Number of Observations per Quarter } \\
\text { Fiscal }\end{array}$} \\
\hline & $\mathrm{N}$ & $\%$ & $\mathrm{~N}$ & $\%$ & $\mathrm{~N}$ & $\%$ \\
\hline 1 & 1,154 & 24.81 & 1,154 & 24.81 & 2,308 & 24.81 \\
\hline 2 & 1,160 & 24.94 & 1,160 & 24.94 & 2,320 & 24.94 \\
\hline 3 & 1,136 & 24.42 & 1,136 & 24.42 & 2,272 & 24.42 \\
\hline 4 & 1,201 & 25.82 & 1,201 & 25.82 & 2,402 & 25.82 \\
\hline Total & 4,651 & 100 & 4,651 & 100 & 9,302 & 100 \\
\hline
\end{tabular}




\section{CHAPTER 3}

\section{The Effect of Management Forecasts on Information Asymmetry Among Investors}

Table 3.1 Panel B and Table 3.2 Panel B show that in both the unmatched and matched samples forecasting firms have different trading volume and price reactions at the two disclosure dates: unadjusted volume, excess trading volume and price reactions are all higher at the management forecast date.

\subsubsection{Results of Hypothesis Tests}

\section{Information Asymmetry around Management Forecasts}

Hypotheses $1 \mathrm{a}$ and $1 \mathrm{~b}$ compare the trading volume reaction related to both preannouncement and event-period information of forecasting firms at the management forecast date with that of non-forecasting firms at the earnings announcement. Using the matched sample, the results of Model (2) are shown in Table 3.3, Columns 1 and 2. For non-forecasters and forecasters alike, both the coefficient of LARET $\left(\beta_{1}=0.174, \mathrm{p}<\right.$ $0.001 ; \beta_{1}=0.217, \mathrm{p}<0.001$, respectively) and the constant $\left(\beta_{0}=0.969, \mathrm{p}<0.001 ; \beta_{0}=\right.$ $1.596, \mathrm{p}<0.001$, respectively) are positive and significant, as expected. The coefficient on LARET, $\beta_{1}$, for forecasters at the forecast date is significantly higher than for nonforecasters at the earnings announcement $\left(\mathrm{Chi}^{2}=9.70, \mathrm{p}=0.002\right)$, i.e. management forecasts generate more trading volume associated with the magnitude of contemporaneous price change than the earnings announcement of non-forecasting firms. This implies that management forecasts motivate the acquisition of more private information than earnings announcements prior to the announcement. This confirms Hypothesis 1a: All else equal, a management forecast motivates the acquisition of more private information, and hence generates more information asymmetry among investors prior to the disclosure than the earnings announcement (of non-forecasters). 
CHAPTER 3

The Effect of Management Forecasts on Information Asymmetry Among Investors

Table 3.3 - Volume Reaction of Non-Forecasting Firms at the Earnings Announcement and Forecasting Firms at the Management Forecast and Earnings Announcement

Trading volume regressions based on the following model:

EXVOL $=\beta_{0}+\beta_{1}$ LARET + Control variables $+\varepsilon$

\begin{tabular}{|c|c|c|c|c|c|}
\hline \multirow[b]{2}{*}{ EXVOL } & \multirow{2}{*}{$\begin{array}{c}(1) \\
\text { Non-Forecasters } \\
\text { aEAD } \\
\end{array}$} & \multirow{2}{*}{$\begin{array}{c}\text { (2) } \\
\text { Forecasters } \\
\text { aMEF } \\
\end{array}$} & \multirow{2}{*}{$\begin{array}{c}\text { (3) } \\
\text { Forecasters } \\
\text { aEAD } \\
\end{array}$} & \multicolumn{2}{|c|}{ Chi $^{2}$ Test } \\
\hline & & & & $(1) \&(2)$ & (1)\&(3) \\
\hline Constant & $\begin{array}{c}0.969 * * * \\
(0.000)\end{array}$ & $\begin{array}{c}1.596 * * * \\
(0.000)\end{array}$ & $\begin{array}{c}0.907 * * * \\
(0.000)\end{array}$ & $\begin{array}{c}28.15 \\
(0.000)\end{array}$ & $\begin{array}{c}0.27 \\
(0.601)\end{array}$ \\
\hline LARET & $\begin{array}{c}0.174 * * * \\
(0.000)\end{array}$ & $\begin{array}{c}0.217 * * * \\
(0.000)\end{array}$ & $\begin{array}{c}0.130 * * * \\
(0.000)\end{array}$ & $\begin{array}{c}9.70 \\
(0.002)\end{array}$ & $\begin{array}{c}12.26 \\
(0.001)\end{array}$ \\
\hline SURP & $\begin{array}{c}0.091 \\
(0.525)\end{array}$ & $\begin{array}{c}-0.102 \\
(0.434)\end{array}$ & $\begin{array}{c}-0.224 * * * \\
(0.007)\end{array}$ & & \\
\hline SIGN & $\begin{array}{l}-0.012 \\
(0.596)\end{array}$ & $\begin{array}{c}0.012 \\
(0.552)\end{array}$ & $\begin{array}{c}-0.172 * * * \\
(0.000)\end{array}$ & & \\
\hline SIZE & $\begin{array}{c}-0.000^{* * *} * \\
(0.000)\end{array}$ & $\begin{array}{c}-0.000^{* * *} \\
(0.001)\end{array}$ & $\begin{array}{c}-0.000 \\
(0.120)\end{array}$ & & \\
\hline MB & $\begin{array}{c}0.000 \\
(0.709)\end{array}$ & $\begin{array}{c}0.000 * * \\
(0.014)\end{array}$ & $\begin{array}{c}0.000 * * \\
(0.031)\end{array}$ & & \\
\hline $\begin{array}{l}\text { Year FE } \\
\text { Quarter } \\
\text { FE }\end{array}$ & $\begin{array}{l}\text { YES } \\
\text { YES }\end{array}$ & $\begin{array}{l}\text { YES } \\
\text { YES }\end{array}$ & $\begin{array}{l}\text { YES } \\
\text { YES }\end{array}$ & & \\
\hline $\begin{array}{l}\mathrm{N} \\
\text { Adj. } \mathrm{R}^{2}\end{array}$ & $\begin{array}{l}4,651 \\
0.137\end{array}$ & $\begin{array}{l}4,651 \\
0.215\end{array}$ & $\begin{array}{l}4,651 \\
0.168\end{array}$ & & \\
\hline
\end{tabular}

Standard errors clustered by firm, robust p-values reported in parentheses.

$*, * *, * * *$ Significant at $10 \%, 5 \%, 1 \%$ levels, respectively, based on two-tailed tests.

$\mathrm{Chi}^{2}$ Test Test of difference in coefficients, two-tailed p-values reported in parentheses.

a Using 1995 as the benchmark year.

EXVOL is excess trading volume, the natural log of cumulative daily trading volume over the three-day event window centered on the day of the quarterly earnings announcement one day before the announcement date $($ day -1$)$ to one day after the announcement date $($ day +1$)$, less the natural log of the firm-specific annual median trading volume. Median trading volume is the median volume for contiguous three-day periods over the 249 trading days prior to the earnings announcement event window. LARET is the magnitude of price change, the natural log of the absolute value of the sum of the firm's daily returns over the three-day event windows. SURP is quarterly earnings surprise, the absolute value of the difference between the actual earnings per share and the consensus analyst earnings forecast outstanding on the day of the announcement, scaled by the share price. SIGN is sign of the earnings surprise, indicator variable, 1 if earnings surprise, SURP, is negative, and 0 otherwise. SIZE is firm size, share price times outstanding shares five days prior to the event window. MB is the market to book ratio, the ratio of market to book value of the firm's common equity at beginning of fiscal year.

The constant, $\beta_{0}$, is also significantly higher for forecasting firms using 1995 as the benchmark year $\left(\mathrm{Chi}^{2}=28.15, \mathrm{p}<0.001\right)$. Alternating the benchmark year, the constant is significantly higher for forecasters 10 times at $1 \%$ and an additional 5 times at $10 \%$ out 


\section{CHAPTER 3}

\section{The Effect of Management Forecasts on Information Asymmetry Among Investors}

of 17 regressions. ${ }^{16}$ These results imply that management forecasts generate more private event-period information compared with earnings announcements and confirm Hypothesis 1b: All else equal, a management forecast generates more event-period private information, hence also higher information asymmetry among investors than the earnings announcement (of non-forecasting firms).

\section{Information Asymmetry around Earnings Announcements}

Hypotheses $2 \mathrm{a}$ and $2 \mathrm{~b}$ examine whether the volume reaction to pre-announcement and event-period private information at the earnings announcement is different between forecasting and non-forecasting firms, i.e. whether the management forecast influences excess trading volumes at the subsequent earnings announcement. The results of Model (2), the excess trading volume regression of forecasting and non-forecasting firms at the earnings announcement are shown in Table 3.3, Columns 1 and 3. Both $\beta_{1}$, the coefficient of LARET, and $\beta_{0}$, the constant, are positive and significant also in the forecasting firm regression $\left(\beta_{1}=0.130, \mathrm{p}<0.001 ; \beta_{0}=0.907, \mathrm{p}<0.001\right)$, as expected. This implies that the earnings announcement of both forecasting and non-forecasting firms induces trading volume associated with pre-announcement private information as well as event-period private information. The coefficient on LARET, $\beta_{1}$, is significantly higher in the nonforecasting firm regression $\left(\mathrm{Chi}^{2}=12.26, \mathrm{p}=0.001\right)$, this means that non-forecasting firms generate significantly more trading volume associated with the magnitude of contemporaneous price change. This implies that the management forecast reduces the motivation of investors to acquire private information and hence prior to the release of the earnings announcement, investors of forecasting firms face lower information asymmetry. In other words, this finding is consistent with the argument that management forecasts substitute for investors' private information acquisition activities. These findings confirm Hypothesis 2a.

${ }^{16}$ The exceptions, when the constant, $\beta_{0}$, is not higher for forecasting firms, are the regressions with 2000 and 2011 as benchmark years. 


\section{CHAPTER 3}

The Effect of Management Forecasts on Information Asymmetry Among Investors

The difference in the constants, $\beta_{0}$, however, is only significant in 2 out of the 17 regressions ${ }^{17}$. Using 1995 as the benchmark year, for example, the difference in constants is insignificant $\left(\mathrm{Chi}^{2}=0.27, \mathrm{p}=0.601\right)$, implying that forecasting firms do not generate less trading volume associated with event-period private information at the earnings announcement. This means that the earnings information conveyed by the earnings announcement does not generate less information asymmetry among investors of forecasting firms, or in other words, management forecasts do not help in the processing of the subsequent earnings announcement. Therefore, Hypothesis $2 \mathrm{~b}$ is rejected.

\section{Overall Information Asymmetry}

I examine the total effect of management forecasts on information asymmetry among investors related to the pre-announcement information component by comparing the results of regressions testing Hypotheses 1a and 2a. As the results in Table 3.3 show, the management forecast in isolation creates higher information asymmetry compared to the earnings announcement $\left(\mathrm{Chi}^{2} 1 \& 2=9.70, \mathrm{p}=0.002\right)$, while the information asymmetry prior to the (subsequent) earnings announcement is lower for forecasting firms $\left(\mathrm{Chi}^{2} 1 \& 3\right.$ $=12.26, \mathrm{p}=0.001)$. To be able to compare the differences in the coefficient of LARET, $\beta_{1}$, between forecasting firms at the management forecast and the benchmark (nonforecasting firms at the earnings announcement) and forecasting firms at the earnings announcement and the benchmark respectively, I use Model (3). As the results in Table 3.4 show, I find that the differences in LARET, at the two disclosure dates for forecasting firms, compared to the benchmark of non-forecasting firms at the earnings announcement (the interaction terms of LARET with FOR and FEA, the period indicator variables) are both highly significant $\left(\beta_{4}=0.048, \mathrm{p}<0.001 ; \beta_{5}=-0.038, \mathrm{p}<0.001\right)$. When I compare the magnitude of these differences at the two disclosure dates I find that they are not different $\left(\mathrm{Chi}^{2}=0.19, \mathrm{p}=0.662\right)$. This means that the higher excess trading volume of forecasting firms related to information asymmetry among investors prior to the

${ }^{17}$ The exceptions, when the difference in the constant, $\beta_{0}$, is significantly different for forecasting firms, are the regressions with 1996 and 2000 as benchmark years. 


\section{CHAPTER 3}

The Effect of Management Forecasts on Information Asymmetry Among Investors

management forecast equals the decrease in excess trading volume at the earnings announcement date. In other words, taking into account the higher information asymmetry at the forecast and the lower one at the earnings announcement among investors of forecasting firms, overall there is no difference between the total information asymmetry associated with pre-announcement private information between forecasting and non-forecasting firms. This suggests that the private information acquisition activities of investors of forecasting firms prior to the management forecast release date creates larger information asymmetry at the management forecast date but results in less information asymmetry prior to the subsequent earnings announcement either due to less information collection or reduced trading opportunities. In sum, the total information asymmetry associated with pre-announcement information is not different between forecasting and non-forecasting firms, because the higher information asymmetry among investors of forecasting firms at the management forecast date is fully compensated by the lower information asymmetry at the earnings announcement.

Next, I examine the total effect of management forecasts on information asymmetry related to the event-period information component by comparing the results of regressions testing Hypotheses $1 \mathrm{~b}$ and $2 \mathrm{~b}$. As the constants in Table 3.3 show, the management forecast in isolation generates higher excess trading volume associated with event-period information compared to the earnings announcement (using 1995 as benchmark year $\left.\mathrm{Chi}^{2} 1 \& 2=28.15, \mathrm{p}<0.001\right)$, while the excess trading volume generated by the earnings announcement is not different for forecasting firms (using 1995 as benchmark year $\mathrm{Chi}^{2} 1 \& 3=0.27, \mathrm{p}=0.601$ ). To compare the differences in the constant, $\beta_{0}$, between forecasting firms at the management forecast and the benchmark (nonforecasting firms at the earnings announcement) and forecasting firms at the earnings announcement and the benchmark, respectively, I employ Model (3). As results in Table 3.4 show, I confirm that the difference between trading volumes associated with eventperiod information for forecasting firms at the forecast date and the benchmark (nonforecasting firms at the earnings announcement), measured by FOR, the indicator variable for forecasting firms at the management forecast date, is highly significant $\left(\beta_{3}=0.290, p\right.$ $<0.001$ ), but in contrast to the results of Model (2) in Table 3.3, I find that the difference 


\section{CHAPTER 3}

The Effect of Management Forecasts on Information Asymmetry Among Investors

between trading volumes associated with event-period information for forecasting firms at the earnings announcement and the benchmark (non-forecasting firms at the earnings announcement), measured by FEA, the indicator variable for forecasting firms at the management forecast date, is also significant $\left(\beta_{4}=-0.126, p=0.006\right)$. Comparing the magnitude of the differences at these two disclosure dates I find that they are significantly different $\left(\mathrm{Chi}^{2}=3.50, \mathrm{p}=0.062\right)$. This means that the higher excess trading volume associated with event-period information generated by the management forecast of forecasting firms is not compensated by the lower excess trading volume generated at the earnings announcement date. In sum, the total information asymmetry associated with event-period information is higher for forecasting firms compared to non-forecasters, because the increase in information asymmetry for forecasting firms at the management forecast date is higher than the reduction in information asymmetry at the earnings announcement (compared to the benchmark of non-forecasting firms at the earnings announcement).

Taken together, my findings show that investors of forecasting firms face larger overall information asymmetry than investors of non-forecasting firms around public disclosures as a result of the event-period information component: Although the total information asymmetry associated with pre-announcement information is not different between forecasting and non-forecasting firms, the total information asymmetry associated with event-period information is higher for forecasters compared to nonforecasters. 
CHAPTER 3

The Effect of Management Forecasts on Information Asymmetry Among Investors

Table 3.4 - Volume Reaction Overall Effect of Management Forecasts

Trading volume regression based on the following model:

EXVOL $=\beta_{0}+\beta_{1}$ LARET $+\beta_{2}$ FOR $+\beta_{3}$ FEA

$+\beta_{4} \mathrm{FOR} *$ LARET $+\beta_{5}$ FEA $*$ LARET + Control variables $+\varepsilon$

\begin{tabular}{|c|c|c|}
\hline EXVOL & $\begin{array}{c}(1) \\
\text { All Observations } \\
\end{array}$ & $\begin{array}{c}\text { Chi }^{2} \text { Test } \\
H_{0}: \beta_{i}+\beta_{j}=\mathbf{0}\end{array}$ \\
\hline Constant & $\begin{array}{l}1.124 * * * \\
(0.000)\end{array}$ & \\
\hline LARET & $\begin{array}{c}0.175 * * * \\
(0.000)\end{array}$ & \\
\hline FOR & $\begin{array}{c}0.290 * * * \\
(0.000)\end{array}$ & $3.50 *$ \\
\hline FEA & $\begin{array}{c}-0.126^{* * *} \\
(0.006)\end{array}$ & $(0.062)$ \\
\hline FOR*LARET & $\begin{array}{c}0.048 * * * \\
(0.000)\end{array}$ & 0.19 \\
\hline FEA*LARET & $\begin{array}{c}-0.038 * * * \\
(0.003)\end{array}$ & $(0.662)$ \\
\hline SURP & $\begin{array}{l}-0.110^{*} \\
(0.079)\end{array}$ & \\
\hline SIGN & $\begin{array}{c}-0.091 * * * \\
(0.000)\end{array}$ & \\
\hline SIZE & $\begin{array}{c}-0.000 * * * \\
(0.000)\end{array}$ & \\
\hline MB & $\begin{array}{c}0.000 \\
(0.200)\end{array}$ & \\
\hline Year FE & YES & \\
\hline Quarter FE & YES & \\
\hline $\begin{array}{l}\mathrm{N} \\
\text { Adj. } \mathrm{R}^{2}\end{array}$ & $\begin{array}{c}13,953 \\
0.170\end{array}$ & \\
\hline
\end{tabular}

Standard errors clustered by firm, robust $\mathrm{p}$-values reported in parentheses.

$*, * *, * * *$ Significant at $10 \%, 5 \%, 1 \%$ levels, respectively, based on two-tailed tests.

$\mathrm{Chi}^{2}$ Test Test of difference in coefficients, two-tailed $\mathrm{p}$-values reported in parentheses.

EXVOL is excess trading volume, the natural log of cumulative daily trading volume over the three-day event window centered on the day of the quarterly earnings announcement one day before the announcement date (day -1$)$ to one day after the announcement date (day +1$)$, less the natural log of the firm-specific annual median trading volume. Median trading volume is the median volume for contiguous three-day periods over the 249 trading days prior to the earnings announcement event window. LARET is the magnitude of price change, the natural log of the absolute value of the sum of the firm's daily returns over the three-day event windows. FOR is an indicator variable for observations of forecasting firms at the management forecast date. FEA is an indicator variable for observations of forecasting firms at the earnings announcement date. SURP is quarterly earnings surprise, the absolute value of the difference between the actual earnings per share and the consensus analyst earnings forecast outstanding on the day of the announcement, scaled by the share price. SIGN is sign of the earnings surprise, indicator variable, 1 if earnings surprise, SURP, is negative, and 0 otherwise. SIZE is firm size, share price times outstanding shares five days prior to the event window. $\mathrm{MB}$ is the market to book ratio, the ratio of market to book value of the firm's common equity at the beginning of the fiscal year. 


\section{CHAPTER 3}

\section{The Effect of Management Forecasts on Information Asymmetry Among Investors}

\subsubsection{Additional Analysis - Forecast Specificity}

In the main analyses I have hypothesized and shown that information asymmetry related to public disclosures differs between forecasting and non-forecasting firms in pattern and in magnitude. In developing my hypotheses I have suggested that these differences are likely to be explained by the different attributes of management forecasts compared to earnings announcements. In the following I examine whether forecast specificity, a prominent management forecast attribute, is associated with the observed excess trading volume differences.

Trading volume theory is silent on forecast specificity, and further, its predictions related to the precision of public disclosures are also ambiguous. Kim and Verrecchia (1991a, 1991b, 1994) model the effects of investor beliefs and disclosure characteristics on volume reactions and show that trading volume increases in the realized precision of a public disclosure. However, these one-dimension models only include differential pre-announcement information but not the event-period information component. In their comprehensive model Kim and Verrecchia (1997) model the volume reaction of the expected precision of the disclosure and show that it has no direct effect on the volume reaction. But the comprehensive theory is silent on the volume reaction to realized precision of disclosures. In sum, the effect of the precision of a public disclosure, more specifically, of the specificity of a management forecast on excess trading volume is unclear.

Because the realized precision of management forecasts cannot influence the amount of private information collected by investors prior to the forecast release date, I do not expect a relationship between forecast specificity and the differential precision of investors' private information prior to the management forecast. However, the specificity of the management forecast may influence the processing of the earnings information conveyed by the forecast: Baginski et al. (1993) explain that the specificity of management forecasts is used by management to communicate their uncertainty about their firm's earnings prospects. Therefore, I expect that more specific forecasts decrease the information asymmetry generated by the management forecast. 


\section{CHAPTER 3}

The Effect of Management Forecasts on Information Asymmetry Among Investors

In addition to the effect of forecast specificity on trading volumes at the release of the management forecast, forecast specificity may also affect trading volumes at the earnings announcement date. Forecast specificity may influence investors' information acquisition activities following the forecast but prior to the earnings announcement, thereby influencing the differential precision of pre-announcement private information of investors. Furthermore, the differences in the specificity of the management forecast may differentially influence the amount of event-period information generated by the subsequent earnings announcement.

To examine the effect of forecast specificity on trading volumes at the management forecast and earnings announcement date, I include forecast specificity indicator variables in Model (2). Based on the work of Anilowski et al. (2007), I classify management EPS forecasts into point, range, and other (open-ended and qualitative) forecasts. Point forecasts are expressed as a specific number without conditioning phrases (e.g., between, more than, at least). Range forecasts are expressed as a closed interval with both ends of the interval bounded (e.g., between, low end of, high end of). Openended forecasts are expressed as an open interval (e.g., more than, at least, as high as). Qualitative forecasts do not contain numerical references (e.g., below expectations, okay with expectations). Point forecasts are considered to be the most specific forecasts, followed by range forecasts, while open-ended forecasts and qualitative forecasts are considered the least specific forecasts, based on the levels of (un)certainty conveyed in the forecast by managers (Baginski et al., 1993). I use the following two empirical models to examine the effect of forecast specificity on trading volumes:

$$
\begin{aligned}
& \text { EXVOL }=\beta_{0}+\beta_{1} \text { LARET }+\beta_{2} \text { POINT }+ \text { Control variables }+\varepsilon \\
& \begin{aligned}
\text { EXVOL }= & \beta_{0}+\beta_{1} \text { LARET }+\beta_{2} \text { POINT } \\
& +\beta_{3} \text { LARET } * \text { POINT }+ \text { Control variables }+\varepsilon
\end{aligned}
\end{aligned}
$$

Where:

LARET is the magnitude of contemporaneous price change as explained above, but it is mean-centered. I mean center LARET in Models (4) and (5) so that the effect of 


\section{CHAPTER 3}

\section{The Effect of Management Forecasts on Information Asymmetry Among Investors}

POINT on LARET, $\beta_{3}$, can be interpreted when LARET is at its mean value, rather than as the simple effect of LARET when POINT is 0 .

POINT is a forecast specificity indicator variable, equal to one if the management forecast is a point forecast, and zero otherwise. To test the robustness of the results, I include alternative specifications for the specificity variable in Model (4) and (5): RANGE (equal to one if the management forecast is a range forecast, and zero otherwise), and both POINT and RANGE. In addition, I replace POINT with SPECIFICITY, where point forecasts are classified as 2 , range forecasts as 1 , and other forecasts as 0 .

I examine the regression coefficients at both the management forecast date and the earnings announcement date. I expect the coefficient on POINT, $\beta_{2}$, to be negative in the regression at the management forecast date, because a more specific forecast is hypothesized to generate less private event-period information and therefore, less information asymmetry among investors at the management forecast date. In line with these expectations, with decreasing specificity I expect the coefficients of alternative specificity variables to be increasingly positive. However, I have no expectations for the signs of the coefficients on the forecast specificity variables in the regression at the earnings announcement date.

Table 3.5 shows the descriptive statistics of my forecasting sample by forecast type. The distribution of forecast specificity is uneven in the sample. The majority of the sample firms (70\%) issue range forecasts, while point forecasts, the most specific forecast type, are issued by less than $20 \%$ of the sample firms. This forecast specificity distribution explains why the mean (1.082) and median (1) of the SPECIFICITY variable indicates that the sample on average is characterized by range forecasts. 
Table 3.5 - Distribution of Sample by Forecast Type

\begin{tabular}{|c|c|c|c|c|c|c|}
\hline \multicolumn{3}{|c|}{ Panel A - Forecast specificity } & \multicolumn{4}{|c|}{ Panel B - SPECIFICITY descriptives } \\
\hline & $\mathrm{N}$ & $\%$ & $\mathrm{~N}$ & Mean & Median & SD \\
\hline Point & 904 & 19.44 & 4,651 & 1.082 & 1 & 0.549 \\
\hline Range & 3,216 & 69.15 & & & & \\
\hline Open-ended & 512 & 11.01 & & & & \\
\hline Qualitative & 19 & 0.41 & & & & \\
\hline Total & 4,651 & 100 & & & & \\
\hline \multicolumn{7}{|c|}{$\begin{array}{l}\text { Point forecasts are a specific number without conditioning phrases. Range forecasts are a closed interval with } \\
\text { both ends of the interval bounded. Open-ended forecasts are an open interval. Qualitative forecasts do not } \\
\text { contain numerical references. } \\
\text { SPECIFICITY is a categorical variable on management forecast specificity, point forecasts are classified as } \\
2 \text {, range forecasts as } 1 \text {, and other forecasts as } 0 \text {. }\end{array}$} \\
\hline
\end{tabular}

Regression results in Table 3.6 show that, in line with expectations, the volume reaction associated with pre-announcement private information at the management forecast date is not affected by forecast specificity. The coefficient on LARET, $\beta_{1}$, is not affected by the inclusion of forecast specificity variables compared to the coefficient in Table 3.3 Column 2. The excess volume associated with event-period private information, however, is influenced by forecast specificity. As results in Table 3.6 Column 2 show, the coefficient on POINT, $\beta_{2}$, is significant and negative, as expected. As shown in Columns 3 to 5 , the results are robust to alternative variable specifications. Using RANGE, the coefficient is significant and positive; including both POINT and RANGE, the signs of the coefficients are as expected, but the coefficient is only significant for RANGE; using SPECIFICITY the coefficient is significantly negative as expected. This implies that the higher precision of earnings information conveyed in the form of a more specific management forecast indicates higher certainty about the earnings expectations of management, and hence generates less event-period information or information asymmetry among investors, compared to less specific management forecasts. 


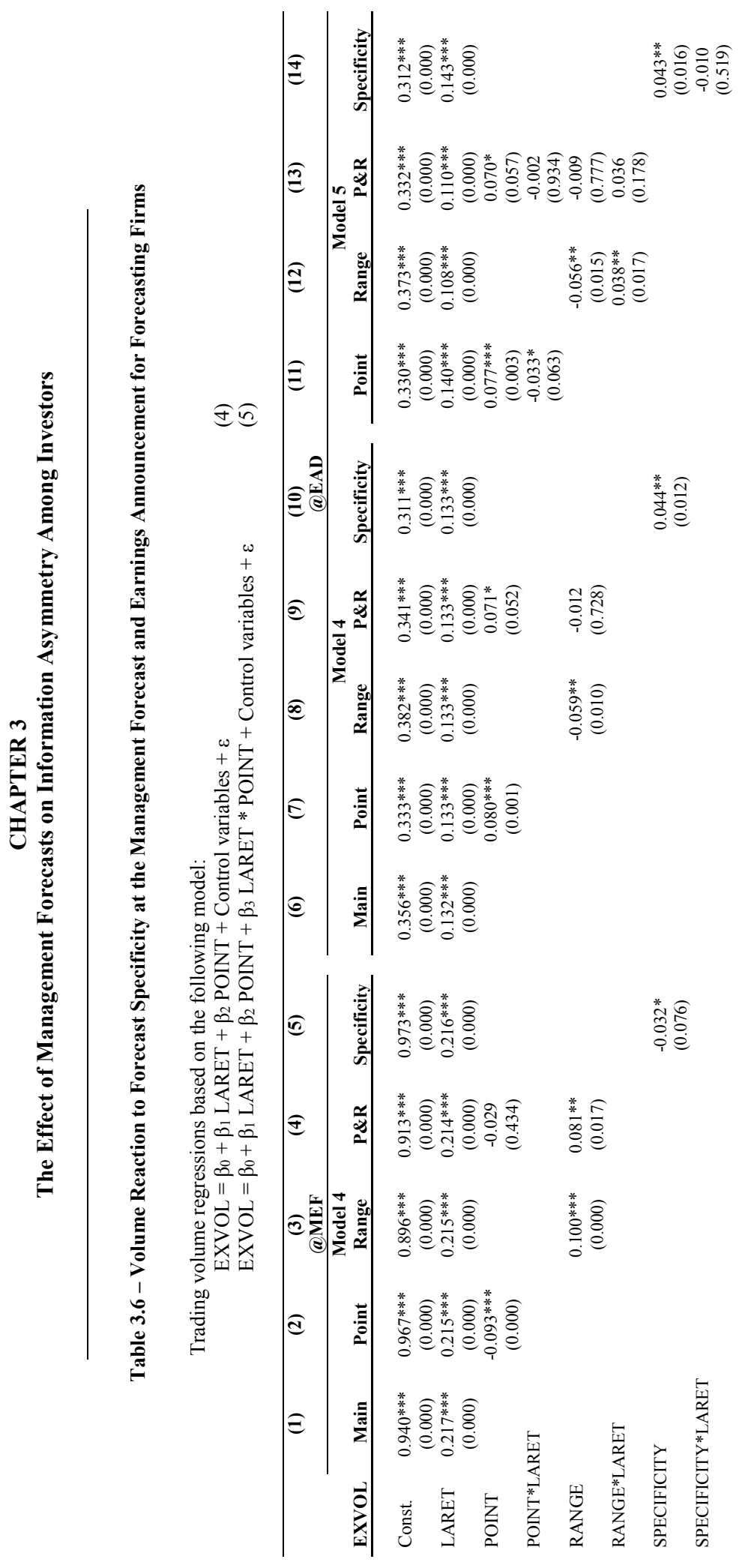




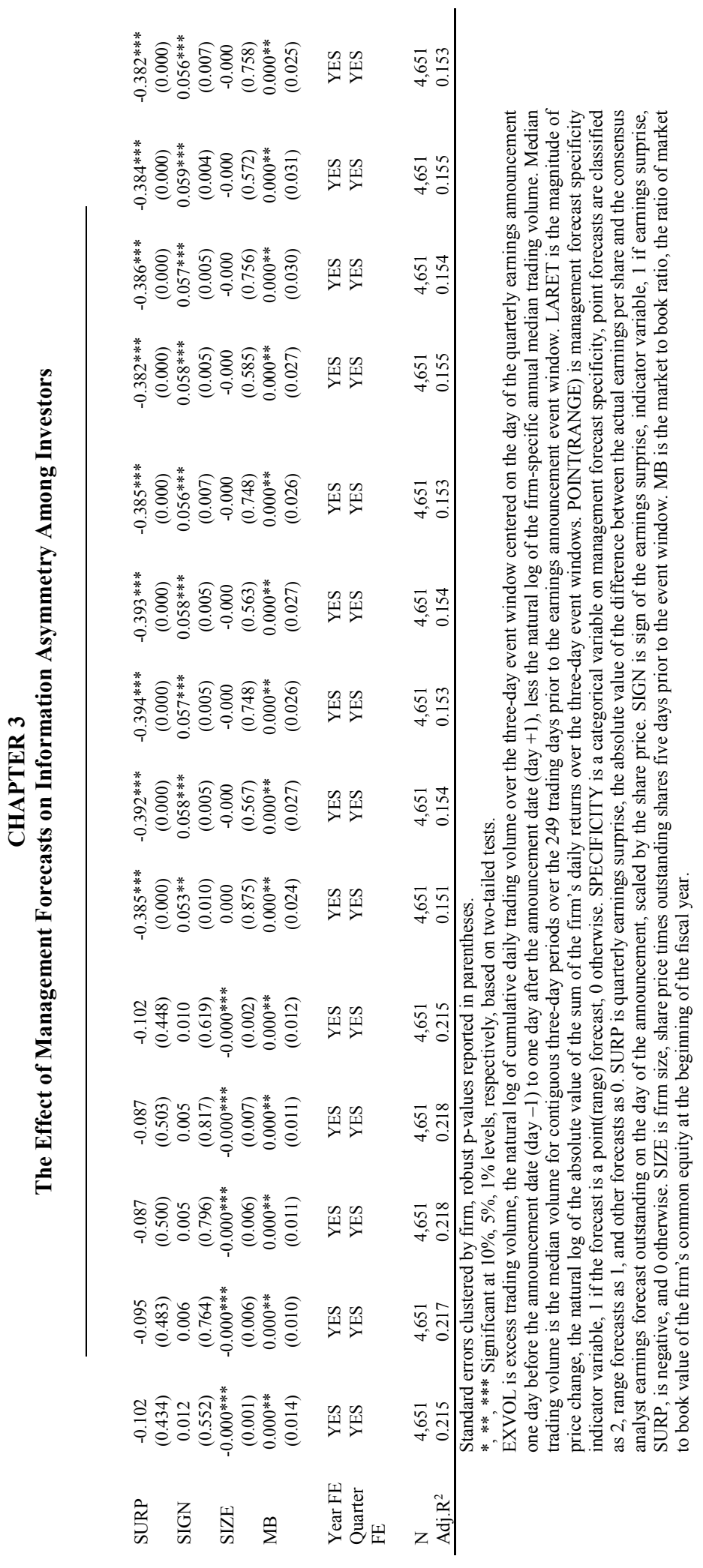




\section{CHAPTER 3}

The Effect of Management Forecasts on Information Asymmetry Among Investors

Results in Table 3.6 Columns 6 to 10 show that the excess volume associated with eventperiod private information at the earnings announcement date is influenced by forecast specificity. The coefficient for POINT, $\beta_{2}$, is positive and significant, for RANGE, negative and significant, while for SPECIFICITY it is also positive and significant. These findings suggest that a more specific management forecast increases the private eventperiod information component at the earnings announcement compared to a less specific forecast. This finding seems counterintuitive, but it is in line with the argument that investors rely more on a more specific forecast when processing the information in the earnings announcement, and therefore, a more specific forecast, in combination with the earnings announcement, generates more private information and more disagreement, in other words, more information asymmetry among investors.

The results in Columns 6 to 10 further show that the volume reaction associated with pre-announcement private information at the earnings announcement date is not influenced by forecast specificity, because the coefficient on LARET, $\beta_{1}$, is not affected by the inclusion of forecast specificity variables compared to the coefficient in Table 3.3 Column 3. The inclusion of the interaction term between LARET and forecast specificity variables in Columns 11 to 14, however, give rise to a different interpretation. The coefficients on the main effects of the specificity variables are significant, their sign is unchanged and there remains an event-period information effect, however, the coefficient of the interaction term of LARET and POINT (RANGE) is significant and negative (positive). The results in Columns 13 and 14, based on alternative specifications (of including both POINT and RANGE or using SPECIFICITY) are qualitatively similar, although coefficients are less or not significant. This implies that earnings information conveyed by the specificity of the management forecast is not entirely used up by investors in trading at the time the management forecast is issued. This information spills over to be used at the earnings announcement. In addition to generating more event-period information, higher management forecast specificity seems to affect the amount of private information investors have prior to the earnings announcement: The more specific the management forecast, the lower the information asymmetry among investors prior to the earnings announcement, and the lower the trading volume associated with the magnitude 


\section{CHAPTER 3}

The Effect of Management Forecasts on Information Asymmetry Among Investors

of the contemporaneous price change. This finding is consistent with the argument that a more precise management forecast compared to a less specific one reduces investors' motivation to acquire private information.

\subsubsection{Additional Analysis - Effect of Regulation Fair Disclosure}

By banning the selective disclosure practices of some firms to analysts and institutional investors, the aim of Regulation Fair Disclosure (RegFD) was to ensure equal access to private information by individual investors, and to decrease the informational disadvantages they face arising from unequal access to private information (SEC, 2000). Research on the effects of RegFD has accumulated evidence that the regulation has caused a fundamental change in the information environment of firms with regards to information asymmetry among investors. Specifically, in a trading volume study Ahmed and Schneible (2007) find that in the post-RegFD period the pre-announcement information asymmetry component has decreased and the event-period information asymmetry component has increased in the market. Therefore, in this section, I examine whether my main results on the information asymmetry among investors of forecasting and non-forecasting firms are affected by the introduction of RegFD.

\section{Pre-RegFD Period}

The results for Hypothesis $1 \mathrm{a}$ and $1 \mathrm{~b}$, comparing the trading volume reaction related to both pre-announcement and event-period information of forecasting firms at the management forecast date with that of non-forecasting firms at the earnings announcement in the pre-RegFD period are shown in Table 3.7 Panel A Columns 1 and 2. For non-forecasters and forecasters alike, both the coefficient of LARET $\left(\beta_{1}=0.168\right.$, $\mathrm{p}<0.001 ; \beta_{1}=0.286, \mathrm{p}<0.001$, respectively) and the constant $\left(\beta_{0}=0.895, \mathrm{p}<0.001 ; \beta_{0}\right.$ $=1.821, \mathrm{p}<0.001$, respectively, with 1995 as benchmark year) are positive and significant. Furthermore, in the pre-RegFD period in line with the main results, the coefficient on LARET, $\beta_{1}$, for forecasters at the forecast date is significantly higher than for non-forecasters at the earnings announcement $\left(\mathrm{Chi}^{2}=26.73, \mathrm{p}<0.000\right)$, and all the constants, $\beta_{0}$, are also significantly higher for forecasting firms when alternating the 
benchmark year $\left(\mathrm{Chi}^{2}=44.16, \mathrm{p}<0.001\right.$, with 1995 as benchmark year $)$. This means that consistent with the main results, in the pre-RegFD period management forecasts generate more trading volume associated with the magnitude of contemporaneous price change and also trading volume independent of price change than the earnings announcement of non-forecasting firms.

Table 3.7 - Volume Reaction of Non-Forecasting Firms at the Earnings Announcement and Forecasting Firms at the Management Forecast and Earnings Announcement in the Pre- and Post-RegFD Period

Trading volume regressions based on the following model:

EXVOL $=\beta_{0}+\beta_{1}$ LARET + Control variables $+\varepsilon$

\begin{tabular}{|c|c|c|c|c|c|}
\hline \multicolumn{2}{|c|}{$\begin{array}{lc}\text { Panel A - Pre-RegFD Period } \\
& (1) \\
& \text { Non-Forecasters } \\
\text { EXVOL } & \text { aEAD }\end{array}$} & $\begin{array}{l}\text { (2) } \\
\text { Forecasters } \\
\text { (a)MEF }\end{array}$ & $\begin{array}{l}\text { (3) } \\
\text { Forecasters } \\
\text { aEAD }\end{array}$ & (1)\&(2) & (1)\&(3) \\
\hline Constant & $\begin{array}{c}0.895^{* * *} * \\
(0.000)\end{array}$ & $\begin{array}{c}1.821 * * * \\
(0.000)\end{array}$ & $\begin{array}{c}0.911 * * * \\
(0.000)\end{array}$ & $\begin{array}{c}44.16 \\
(0.000)\end{array}$ & $\begin{array}{c}0.01 \\
(0.911)\end{array}$ \\
\hline LARET & $\begin{array}{c}0.168 * * * \\
(0.000)\end{array}$ & $\begin{array}{c}0.286^{* * *} \\
(0.000)\end{array}$ & $\begin{array}{c}0.114 * * * \\
(0.000)\end{array}$ & $\begin{array}{c}26.73 \\
(0.000)\end{array}$ & $\begin{array}{c}7.26 \\
(0.007)\end{array}$ \\
\hline SURP & $\begin{array}{l}-0.099 \\
(0.532)\end{array}$ & $\begin{array}{c}-0.058 \\
(0.497)\end{array}$ & $\begin{array}{c}-0.326^{* * *} \\
(0.001)\end{array}$ & & \\
\hline SIGN & $\begin{array}{c}0.011 \\
(0.789)\end{array}$ & $\begin{array}{l}-0.035 \\
(0.419)\end{array}$ & $\begin{array}{c}-0.245^{* * *} \\
(0.000)\end{array}$ & & \\
\hline SIZE & $\begin{array}{c}-0.000 \\
(0.135)\end{array}$ & $\begin{array}{c}-0.000 * * * \\
(0.000)\end{array}$ & $\begin{array}{l}-0.000 \\
(0.480)\end{array}$ & & \\
\hline MB & $\begin{array}{c}0.000 * * \\
(0.015)\end{array}$ & $\begin{array}{c}0.000 \\
(0.234)\end{array}$ & $\begin{array}{c}0.000 \\
(0.268)\end{array}$ & & \\
\hline $\begin{array}{l}\text { Year FE } \\
\text { Quarter FE }\end{array}$ & $\begin{array}{l}\text { YES } \\
\text { YES }\end{array}$ & $\begin{array}{l}\text { YES } \\
\text { YES }\end{array}$ & $\begin{array}{l}\text { YES } \\
\text { YES }\end{array}$ & & \\
\hline $\begin{array}{l}\mathrm{N} \\
\text { Adj. } \mathrm{R}^{2}\end{array}$ & $\begin{array}{l}1,809 \\
0.097\end{array}$ & $\begin{array}{l}1,809 \\
0.267\end{array}$ & $\begin{array}{l}1,809 \\
0.100\end{array}$ & & \\
\hline
\end{tabular}

Standard errors clustered by firm, robust p-values reported in parentheses.

$*, * *, * * *$ Significant at $10 \%, 5 \%, 1 \%$ levels, respectively, based on two-tailed tests.

$\mathrm{Chi}^{2}$ Test Test of difference in coefficients, two-tailed p-values reported in parentheses.

a Using 1995 as the benchmark year.

EXVOL is excess trading volume, the natural log of cumulative daily trading volume over the three-day event window centered on the day of the quarterly earnings announcement one day before the announcement date $($ day -1$)$ to one day after the announcement date $($ day +1$)$, less the natural log of the firm-specific annual median trading volume. Median trading volume is the median volume for contiguous three-day periods over the 249 trading days prior to the earnings announcement event window. LARET is the magnitude of price change, the natural $\log$ of the absolute value of the sum of the firm's daily returns over the three-day event windows. SURP is quarterly earnings surprise, the absolute value of the difference between the actual earnings per share and the consensus analyst earnings forecast outstanding on the day of the announcement, scaled by the share price. 


\section{CHAPTER 3}

The Effect of Management Forecasts on Information Asymmetry Among Investors

SIGN is sign of the earnings surprise, indicator variable, 1 if earnings surprise, SURP, is negative, and 0 otherwise. SIZE is firm size, share price times outstanding shares five days prior to the event window. MB is the market to book ratio, the ratio of market to book value of the firm's common equity at the beginning of the fiscal year.

The results for Hypotheses $2 \mathrm{a}$ and $2 \mathrm{~b}$, comparing the trading volume reaction to preannouncement and event-period private information at the earnings announcement for forecasting and non-forecasting firms in the pre-RegFD period, are shown in Table 3.7 Panel A Columns 1 and 3. Both $\beta_{1}$, the coefficient of LARET, and $\beta_{0}$, the constant, are positive and significant also in the forecasting firm regression $\left(\beta_{1}=0.114, \mathrm{p}<0.001 ; \beta_{0}\right.$ $=0.911, \mathrm{p}<0.001)$. The coefficient on LARET, $\beta_{1}$, is significantly higher in the nonforecasting firm regression $\left(\mathrm{Chi}^{2}=7.26, \mathrm{p}=0.007\right)$, but the difference in the constants, $\beta_{0}$, is not significant in any of the regressions $\left(\mathrm{Chi}^{2}=0.01, \mathrm{p}=0.911\right.$, with 1995 as benchmark year). This means that in line with the main findings, in the pre-RegFD period non-forecasting firms generate significantly more trading volume associated with the magnitude of contemporaneous price change at their earnings announcement than forecasting firms, but there is no difference between their trading volume associated with event-period private information.

To investigate the overall information asymmetry difference between forecasting and non-forecasting firms in the pre-RegFD period, I use Model (3). As the results in Table 3.8 Column 1 show, I find that in the pre-RegFD period the differences in LARET, $\beta_{1}$, at the two disclosure dates for forecasting firms, compared to the benchmark of non-forecasting firms at the earnings announcement (proxied by the interaction terms of LARET with FOR and FEA, the period indicator variables) are both significant $\left(\beta_{4}=0.117, \mathrm{p}<0.001 ; \beta_{5}=-0.050, \mathrm{p}=0.013\right)$, and $\mathrm{I}$ find that the magnitude of the differences at the two disclosure dates are also different $\left(\mathrm{Chi}^{2}=2.91, \mathrm{p}=0.088\right)$. This means that, unlike in my main findings, the higher excess trading volume of forecasting firms related to information asymmetry among investors prior to the management forecast is not equaled by the decrease in excess trading volume at the earnings announcement date. This suggests that the private information acquisition activities of investors of forecasting firms prior to the management forecast release date creates larger information asymmetry at the management forecast date but does not result 


\section{CHAPTER 3}

The Effect of Management Forecasts on Information Asymmetry Among Investors

in comparatively low information asymmetry prior to the subsequent earnings announcement in the pre-RegFD period. In sum, the total information asymmetry associated with pre-announcement information is higher for forecasting firms, because the higher information asymmetry among investors of forecasting firms at the management forecast date is not compensated by an equally reduced information asymmetry at the earnings announcement.

In addition to the results on LARET, I find that the differences in the constant, $\beta_{0}$, at the two disclosure dates for forecasting firms, compared to the benchmark of nonforecasting firms at the earnings announcement (proxied by FOR and FEA, the period indicator variables), are also both significant $\left(\beta_{2}=0.640, \mathrm{p}<0.001 ; \beta_{3}=-0.198, \mathrm{p}=\right.$ 0.008). Comparing the differences at these two disclosure dates I find that their magnitudes are significantly different $\left(\mathrm{Chi}^{2}=10.28, \mathrm{p}=0.001\right)$. This means that, consistent with the main results, in the pre-RegFD period the higher excess trading volume associated with event-period information generated by the management forecast of forecasting firms is not compensated by the lower excess trading volume generated at the earnings announcement date.

In sum, in the pre-RegFD period the investors of forecasting firms face more total information asymmetry both in terms of the pre-announcement and the event-period information components than investors of non-forecasting firms.

\section{Post-RegFD Period}

Results for Hypothesis $1 \mathrm{a}$ and $1 \mathrm{~b}$, as well as $2 \mathrm{a}$ and $2 \mathrm{~b}$ in the post-RegFD period are shown in Table 3.7 Panel B Columns 1 and 2, and Columns 1 and 3, respectively. For non-forecasters and forecasters alike, both the coefficient of LARET $\left(\beta_{1}=0.177, \mathrm{p}<\right.$ $0.001 ; \beta_{1}=0.164, \mathrm{p}<0.001$, respectively) and the constant $\left(\beta_{0}=0.970, \mathrm{p}<0.001 ; \beta_{0}=\right.$ $1.040, \mathrm{p}<0.001$, respectively) are positive and significant. But unlike in the main results, in the post-RegFD period the coefficient on LARET, $\beta_{1}$, for forecasters at the forecast date is not different compared to that for non-forecasters at the earnings announcement $\left(\mathrm{Chi}^{2}=0.64, \mathrm{p}=0.424\right)$ and all the constants, $\beta_{0}$, are also insignificantly different for forecasting firms when alternating the benchmark year $\left(\mathrm{Chi}^{2}=0.72, \mathrm{p}=0.395\right.$, with 1995 


\section{CHAPTER 3}

The Effect of Management Forecasts on Information Asymmetry Among Investors

as the benchmark year). This means that unlike in the main results and in the pre-RegFD period, in the post-RegFD period management forecasts do not generate more trading volume than the earnings announcement of non-forecasting firms. This implies that management forecasts in the post-RegFD period do not motivate the acquisition of more private information than earnings announcements prior to the announcement and do not generate more private event-period information compared with earnings announcements.

Table 3.7 - Volume Reaction of Non-Forecasting Firms at the Earnings Announcement and Forecasting Firms at the Management Forecast and Earnings Announcement in the Pre- and Post-RegFD Period (contd)

\begin{tabular}{|c|c|c|c|c|c|}
\hline \multicolumn{2}{|c|}{$\begin{array}{lc}\text { Panel B - Post-RegFD Period } \\
& (1) \\
& \text { Non-Forecasters } \\
\text { EXVOL } & \text { aEAD } \\
\end{array}$} & $\begin{array}{l}\text { (2) } \\
\text { Forecasters } \\
@ \text { MEF }\end{array}$ & $\begin{array}{l}\text { (3) } \\
\text { Forecasters } \\
\text { aEAD } \\
\end{array}$ & (1)\&(2) & (1)\&(3) \\
\hline Constant & $\begin{array}{c}0.970 * * * \\
(0.000)\end{array}$ & $\begin{array}{c}1.040 * * * \\
(0.000)\end{array}$ & $\begin{array}{c}0.912 * * * \\
(0.000)\end{array}$ & $\begin{array}{c}0.72 \\
(0.395)\end{array}$ & $\begin{array}{c}0.54 \\
(0.465)\end{array}$ \\
\hline LARET & $\begin{array}{c}0.177 * * * \\
(0.000)\end{array}$ & $\begin{array}{c}0.164 * * * \\
(0.000)\end{array}$ & $\begin{array}{c}0.142 * * * \\
(0.000)\end{array}$ & $\begin{array}{c}0.64 \\
(0.424)\end{array}$ & $\begin{array}{c}5.11 \\
(0.024)\end{array}$ \\
\hline SURP & $\begin{array}{c}0.306 * * * \\
(0.002)\end{array}$ & $\begin{array}{c}-1.106 * * \\
(0.048)\end{array}$ & $\begin{array}{c}-0.090 \\
(0.390)\end{array}$ & & \\
\hline SIGN & $\begin{array}{c}-0.021 \\
(0.413)\end{array}$ & $\begin{array}{c}0.021 \\
(0.330)\end{array}$ & $\begin{array}{c}-0.129 * * * \\
(0.000)\end{array}$ & & \\
\hline SIZE & $\begin{array}{c}-0.000 * * * \\
(0.002)\end{array}$ & $\begin{array}{l}-0.000 \\
(0.402)\end{array}$ & $\begin{array}{c}-0.000^{* *} \\
(0.017)\end{array}$ & & \\
\hline MB & $\begin{array}{c}-0.000 \\
(0.804)\end{array}$ & $\begin{array}{c}0.000 * * * \\
(0.004)\end{array}$ & $\begin{array}{l}0.000 * \\
(0.062)\end{array}$ & & \\
\hline $\begin{array}{l}\text { Year FE } \\
\text { Quarter FE }\end{array}$ & $\begin{array}{l}\text { YES } \\
\text { YES }\end{array}$ & $\begin{array}{l}\text { YES } \\
\text { YES }\end{array}$ & $\begin{array}{l}\text { YES } \\
\text { YES }\end{array}$ & & \\
\hline $\begin{array}{l}\mathrm{N} \\
\text { Adj. } \mathrm{R}^{2}\end{array}$ & $\begin{array}{l}2,842 \\
0.150\end{array}$ & $\begin{array}{l}2,842 \\
0.153\end{array}$ & $\begin{array}{l}2,842 \\
0.155\end{array}$ & & \\
\hline
\end{tabular}

Testing Hypotheses $2 \mathrm{a}$ and $2 \mathrm{~b}$ in the post-RegFD period, I find that both $\beta_{1}$, the coefficient of LARET, and $\beta_{0}$, the constant, are positive and significant also in the forecasting firm regression at the earnings announcement $\left(\beta_{1}=0.142, \mathrm{p}<0.001 ; \beta_{0}=0.912, \mathrm{p}<0.001\right)$. Further, in line with the main results I find that the coefficient on LARET, $\beta_{1}$, is significantly higher in the non-forecasting firm regression $\left(\mathrm{Chi}^{2}=5.11, \mathrm{p}=0.024\right)$, but the difference in the constants, $\beta_{0}$, is not significant in any of the regressions $\left(\mathrm{Chi}^{2}=0.54\right.$, $\mathrm{p}=0.465$, with 1995 as the benchmark year). This means that in the post-RegFD period 


\section{CHAPTER 3}

The Effect of Management Forecasts on Information Asymmetry Among Investors

non-forecasting firms still generate significantly more trading volume associated with the magnitude of contemporaneous price change, but there is still no difference between the trading volume associated with event-period private information at the earnings announcement generated by forecasting and non-forecasting firms. Taken together this implies that my main findings relating to the informational differences of management forecasts disappear, but the findings relating to the earnings announcement of the two types of firms hold in the post-RegFD period.

As the results of Model (3) in Table 3.8 Column 2 show, the overall information asymmetry differences between forecasting and non-forecasting firms in the post-RegFD period are both insignificant. The difference in LARET, $\beta_{1}$, at the forecast date for forecasting firms (the interaction term of LARET with FOR) is insignificant $\left(\beta_{4}=-0.012\right.$, $\mathrm{p}=0.452$ ), while that at the earnings announcement (the interaction term of LARET with FEA) it is significant $\left(\beta_{5}=-0.032, p=0.038\right)$. However, I find that the difference in their magnitudes is not significant $\left(\mathrm{Chi}^{2}=2.31, \mathrm{p}=0.128\right)$. This means that, unlike in my main findings, the higher excess trading volume of forecasting firms related to information asymmetry among investors prior to the management forecast does not materialize in the post-RegFD period. This implies that some of the information asymmetry in the preRegFD period may have been caused by selective disclosure (which source has dried up in the post-RegFD period) rather than private information acquisition (assuming that RegFD had no impact on investors' private information acquisition incentives).

In addition to the results on LARET, the differences in the constant, $\beta_{0}$, at the two disclosure dates for forecasting firms, compared to the benchmark of non-forecasting firms at the earnings announcement (proxied by FOR and FEA, the period indicator variables, respectively), are not significant $\left(\beta_{2}=0.001, p=0.987 ; \beta_{3}=-0.088, p=0.121\right)$, and neither is the difference in their magnitudes $\left(\mathrm{Chi}^{2}=0.64, \mathrm{p}=0.422\right)$. This means that, similarly to the main results, in the post-RegFD period the event-period information asymmetry around the two disclosure dates are not different, hence investors of forecasting firms still face higher overall information asymmetry. 
CHAPTER 3

The Effect of Management Forecasts on Information Asymmetry Among Investors

Table 3.8 - Volume Reaction

Overall Effect of Management Forecasts in the Pre- and Post-RegFD Period

Trading volume regression based on the following model:

$\mathrm{EXVOL}=\beta_{0}+\beta_{1}$ LARET $+\beta_{2}$ FOR $+\beta_{3}$ FEA

$+\beta_{4} \mathrm{FOR} *$ LARET $+\beta_{5}$ FEA * LARET + Control variables $+\varepsilon$

\begin{tabular}{|c|c|c|c|c|}
\hline \multirow[b]{2}{*}{ EXVOL } & \multicolumn{2}{|c|}{ Pre-RegFD Period } & \multicolumn{2}{|c|}{ Post-RegFD Period } \\
\hline & $\begin{array}{c}\text { (1) } \\
\text { All Observations } \\
\end{array}$ & $\begin{array}{c}\text { Chi }^{2} \text { Test } \\
\mathbf{H}_{0}: \beta_{\mathrm{i}}+\beta_{\mathrm{j}}=\mathbf{0}\end{array}$ & $\begin{array}{c}\text { (2) } \\
\text { All Observations } \\
\end{array}$ & $\begin{array}{c}\text { Chi }^{2} \text { Test } \\
\mathbf{H}_{0}: \beta_{\mathrm{i}}+\beta_{\mathrm{j}}=\mathbf{0}\end{array}$ \\
\hline Constant & $\begin{array}{c}1.067 * * * \\
(0.000)\end{array}$ & & $\begin{array}{c}0.998 * * * \\
(0.000)\end{array}$ & \\
\hline LARET & $\begin{array}{c}0.170 * * * \\
(0.000)\end{array}$ & & $\begin{array}{c}0.176^{* * *} \\
(0.000)\end{array}$ & \\
\hline FOR & $\begin{array}{c}0.640 * * * \\
(0.000)\end{array}$ & $10.28^{* * *}$ & $\begin{array}{c}0.001 \\
(0.987)\end{array}$ & 0.64 \\
\hline FEA & $\begin{array}{c}-0.198^{* * *} \\
(0.008)\end{array}$ & $(0.001)$ & $\begin{array}{l}-0.088 \\
(0.121)\end{array}$ & $(0.422)$ \\
\hline FOR $*$ LARET & $\begin{array}{c}0.117 * * * \\
(0.000)\end{array}$ & $2.91 *$ & $\begin{array}{l}-0.012 \\
(0.452)\end{array}$ & 2.31 \\
\hline FEA*LARET & $\begin{array}{c}-0.050^{* *} \\
(0.013)\end{array}$ & $(0.088)$ & $\begin{array}{c}-0.032 * * \\
(0.038)\end{array}$ & $(0.128)$ \\
\hline SURP & $\begin{array}{c}-0.191 * * * \\
(0.001)\end{array}$ & & $\begin{array}{l}0.006 \\
(0.960)\end{array}$ & \\
\hline SIGN & $\begin{array}{c}-0.111 * * * \\
(0.000)\end{array}$ & & $\begin{array}{c}-0.048 * * * \\
(0.000)\end{array}$ & \\
\hline SIZE & $\begin{array}{c}-0.000^{* * * *} \\
(0.000)\end{array}$ & & $\begin{array}{c}-0.000^{* *} \\
(0.026)\end{array}$ & \\
\hline MB & $\begin{array}{l}0.000^{* *} \\
(0.014)\end{array}$ & & $\begin{array}{c}0.000 \\
(0.545)\end{array}$ & \\
\hline Year FE & YES & & YES & \\
\hline Quarter FE & YES & & YES & \\
\hline $\mathrm{N}$ & 5,427 & & 8,526 & \\
\hline Adj. $R^{2}$ & 0.210 & & 0.149 & \\
\hline
\end{tabular}

Standard errors clustered by firm, robust p-values reported in parentheses.

$*, * *, * *$ Significant at $10 \%, 5 \%, 1 \%$ levels, respectively, based on two-tailed tests.

$\mathrm{Chi}^{2}$ Test Test of difference in coefficients, two-tailed $\mathrm{p}$-values reported in parentheses.

EXVOL is excess trading volume, the natural log of cumulative daily trading volume over the three-day event window centered on the day of the quarterly earnings announcement one day before the announcement date (day -1$)$ to one day after the announcement date $($ day +1$)$, less the natural $\log$ of the firm-specific annual median trading volume. Median trading volume is the median volume for contiguous three-day periods over the 249 trading days prior to the earnings announcement event window. LARET is the magnitude of price change, the natural $\log$ of the absolute value of the sum of the firm's daily returns over the three-day event windows. FOR is an indicator variable for observations of forecasting firms at the management forecast date. FEA is an indicator variable for observations of forecasting firms at the earnings announcement date. SURP is quarterly earnings surprise, the absolute value of the difference between the actual earnings per share and the consensus analyst earnings forecast outstanding on the day of the announcement, scaled by the share price. SIGN is sign of the earnings surprise, indicator variable, 1 if earnings surprise, SURP, is negative, and 0 otherwise. SIZE is firm size, share price times outstanding shares five days prior to the event window. MB is the market to book ratio, the ratio of market to book value of the firm's common equity at the beginning of the fiscal year. 


\section{CHAPTER 3}

The Effect of Management Forecasts on Information Asymmetry Among Investors

In sum, in the post-RegFD period the investors of forecasting firms do not face more total information asymmetry in terms of pre-announcement information, however, they do face more event-period information asymmetry than investors of non-forecasting firms.

\subsection{Conclusion}

This study examines the effect of voluntary management earnings forecasts on the information asymmetry among investors. More specifically, I investigate the role voluntary management forecasts play in the generation of information asymmetry among investors around public disclosures.

First, I examine excess trading volume reactions associated with both preannouncement and event-period private information at the management forecast date, using the trading volume reaction of non-forecasting firms at the earnings announcement as a benchmark. I find that, in isolation, voluntary management forecasts generate higher information asymmetry among investors than mandatory earnings announcements as evidenced by higher excess trading volume reactions associated with both preannouncement and event-period private information at the management forecast date compared to the trading volume reaction of non-forecasting firms at the earnings announcement. This implies that the information asymmetry among investors is higher when the disclosure involves predictions for the future compared to disclosures that confirm past events.

Next, I examine trading volume reactions associated with both the preannouncement and event period information components around the subsequent earnings announcement of forecasting firms, using non-forecasters as benchmark. I find that earnings announcements of forecasting firms are associated with lower information asymmetry among investors than earnings announcements of non-forecasters since the excess trading volume reactions at the earnings announcement date associated with preannouncement private information are lower, while those associated with event-period private information are not different across forecasters and non-forecasters. 


\section{CHAPTER 3}

The Effect of Management Forecasts on Information Asymmetry Among Investors

Aggregating the trading volume effects of management forecasts from around the forecast issue and the subsequent earnings announcement, I conclude that investors of forecasting firms face a larger overall information asymmetry than investors of nonforecasting firms as a result of the event-period information component. Taking into account the volume effects at both the forecast and earnings announcement date, the aggregate information asymmetry associated with pre-announcement information is not different between forecasting and non-forecasting firms, since the higher trading volume reaction for forecasters at the forecast date is fully compensated by a lower trading volume at the earnings announcement date. This implies that the better informed investors of forecasting firms have a larger informational advantage at the forecast date, but this is 'used up' in trading and does not carry over to the earnings announcement, where the prior informational disadvantage of less informed investors is significantly reduced and is fully compensated. In contrast, the aggregate information asymmetry associated with event-period information is higher for forecasters compared to non-forecasters because the information asymmetry generated by forecasting firms' earnings announcement is not different from that of non-forecasting firms, and hence the higher trading volume reaction at the management forecast date is not compensated by a lower trading volume reaction at the earnings announcement. This implies that on average a management forecast generates the same level of disagreement among investors as an earnings announcement, and moreover, that on average management forecasts do not help in the processing of the subsequent earnings announcement.

Overall my findings imply that rather than leveling the informational playing field among investors, the voluntary disclosure of management forecasts contributes to increasing the informational disadvantage of some investors over others. Furthermore, while more voluntary disclosure may decrease information asymmetry between the firm and its investors as a whole, it may have unintended consequences by increasing the information asymmetry among investors and weakening the disclosure's positive effects on the firm's cost of capital.

In additional analyses, I examine whether the specificity of the management forecast is associated with the observed trading volume effects at the management 


\section{CHAPTER 3}

The Effect of Management Forecasts on Information Asymmetry Among Investors

forecast date and subsequent earnings announcement. I first show that the specificity of the management forecast does not directly influence trading volumes associated with preannouncement private information either at the release of the forecast or at the subsequent earnings announcement. Next, I find that more specific forecasts generate less eventperiod private information and hence less information asymmetry at the forecast date, implying that investors rely more on a specific forecast when making their trading decisions. However, more specific forecasts generate more event-period private information at the earnings announcement in line with the argument that investors rely more on a more specific forecast when processing the earnings announcement information. Furthermore, I find that the specificity of the management forecast creates a spillover effect at the earnings announcement, because more precise management forecasts reduce the information asymmetry prior to the earnings announcement and induce lower excess trading volumes associated with differential pre-announcement private information.

I test the robustness of my main results in the pre- and post-RegFD periods. I find that while in the pre-RegFD period the investors of forecasting firms face more total information asymmetry both in terms of the pre-announcement and the event-period information components than investors of non-forecasting firms, in the post-RegFD period the informational disadvantage of investors of forecasting firms in terms of preannouncement information disappears. Overall my robustness tests show that my main results hold in the post-RegFD period: investors of forecasting firms do not face more pre-announcement information asymmetry in the post-RegFD period than investors of non-forecasting firms, however they do face more event-period information asymmetry than investors of non-forecasting firms due to the additional event-period information component around the management forecast.

I contribute to the trading volume literature by analyzing the excess trading volume effects of unbundled management forecasts and provide evidence on how an additional element of firms' disclosure policy affects information asymmetry among investors (Bamber et al., 2011). Prior literature has examined the trading volume effects of earnings announcements (e.g., Bamber et al., 1997; Barron et al., 2005) and earnings 


\section{CHAPTER 3}

The Effect of Management Forecasts on Information Asymmetry Among Investors

announcements bundled with management forecasts (Barron et al., 2010). By using both unbundled management forecasts and unbundled earnings announcements I am able to examine the excess trading volume effects of management forecasts in isolation as well as their incremental effects on earnings announcements. My results confirm the finding of Barron et al. (2010) that bundled earnings announcements are associated with higher trading volume reactions, but I am able to decompose this effect with regard to management forecasts. Examined in isolation, the pre-announcement information component is unlikely to be responsible for the higher volume reaction of announcements bundled with management forecasts because the higher volume reaction at the management forecast is fully compensated by the opposite effect at the earnings announcement. Therefore, the higher volume reaction around bundled announcements is likely to be caused by the event-period information component, which is equally high at the forecast as well as at the earnings announcement of forecasting firms.

I also contribute to the voluntary disclosure literature by investigating the effect of voluntary management earnings forecasts on the information asymmetry among investors. Information asymmetry among investors, in other words an unequal informational playing field, has long been a regulatory concern (e.g., Morse, 1980; Levitt, 1998a, 1998b, 1999). I show that while management forecasts increase information asymmetry among investors at the release of the management forecast, they are associated with lower information asymmetry among investors prior to the earnings announcement and on average do not help in the processing of the information content of the subsequent earnings announcement. My findings also show that the overall effect of voluntary management forecasts on the information asymmetry among investors is negative: total information asymmetry among investors of forecasting firms, considering both public disclosures, is higher than for investors of non-forecasting firms. The implications of these findings are that rather than making all investors better informed in an equal measure, more (voluntary) disclosure may increase the informational disadvantage of less well-informed investors.

My results have implications for managers, investors and regulators. The managerial implications of my results are that an attempt at improving the information 


\section{CHAPTER 3}

The Effect of Management Forecasts on Information Asymmetry Among Investors

environment of the firm by issuing voluntary management forecasts may have unintended consequences. Accounting literature posits that more publicly available information about a firm decreases the information asymmetry between the firm and its investors, and therefore, has a favorable effect on the firm's cost of capital. However, my results show that increased disclosure in the form of management forecasts may increase the information asymmetry among the investors of the firm. As an increasing number of studies find that information asymmetry among investors increases a firm's cost of capital (e.g., Botosan and Plumlee, 2002; Botosan et al., 2004; Barron et al., 2005), increased voluntary disclosure may reduce the positive effects on the cost of capital achieved through an improved information environment. Furthermore, while most firms issue range forecasts, my additional analyses suggest that investors find the earnings information conveyed by more specific, i.e. point, forecasts easier to understand, and rely more on more specific forecasts to process the subsequent earnings announcement.

My findings also have a number of implications for investors. First, the trading opportunities provided by a voluntary management earnings forecast are more advantageous for investors with more private information prior to the forecast issue, as the information asymmetry among investors is higher prior to the forecast. On the other hand the investors of forecasting firms face reduced trading opportunities at the subsequent earnings announcement, which suggests that private information acquisition activities following the forecast, but prior to the earnings announcement might result in less benefits to investors. In other words to some extent the earnings information contained in the forecast renders private information search superfluous/less useful. Second, because both the forecast and forecasting firms' earnings announcement generate disagreement among investors, investors with better information processing abilities benefit from the additional disclosure of these firms.

The regulatory implications of my findings are that while efforts to level the playing field among investors by ensuring equal access to information communicated by firms to their investors may be a step in the right direction, but equal access to information may still not achieve the desired effects. My results suggest that equal access to management forecasts may not translate into equal informedness: investors may still 


\section{CHAPTER 3}

\section{The Effect of Management Forecasts on Information Asymmetry Among Investors}

derive different benefits from the information, due to different costs and abilities of acquiring and processing forecast earnings information, maintaining, at least in part, the information asymmetry between more and less informed investors.

My study is subject to various limitations. An alternative explanation of my findings, that forecasting firms also have better quality financial statements cannot fully be ruled out and depends on the extent to which the firm characteristics associated with the firm's forecasting choice I use in propensity score matching to select my samples proxy for financial statement quality of the sample firms. Furthermore, in my sample selection I ensure that firm observations where forecasts and earnings announcements are issued on the same date are eliminated from my sample. While this enables me to separate and examine the incremental effect of management forecasts on trading volumes around public disclosures, if bundling firms are different from the unbundling and nonforecasting firms in my sample, my results may not be generalizable. 




\section{The Profitability Effect of Small and Large Investors' Differential Trading around Management Forecasts ${ }^{18,19}$}

${ }^{18}$ This chapter is based on a working paper co-authored with Gerald Lobo and Arpita Shroff.

${ }^{19}$ I am grateful to Gilles Hilary at INSEAD, for a visiting scholarship. I appreciate comments by Neil Bhattacharya, Frank Moers, and Annelies Renders. 


\begin{abstract}
We examine how different investor classes utilize management earnings forecasts in their trading. Specifically, we compare the economic consequences of small investors' trading decisions to those of large investors around management forecasts, using earnings announcements as a benchmark. We find differences in trading behavior of small and large investors at the management forecast compared to the earnings announcement, primarily because small investors trade in the direction of a random walk forecast error around the management forecast but not around earnings announcements, in contrast with large investors, whose trades are not associated with forecast errors around corporate announcements. The consequence of investors differential trading behavior is differential profitability around corporate announcements: management forecasts improve the profitability difference of small investors' trades compared to earnings announcements by turning a differential loss at the earnings announcement into a differential profit at the management forecast compared to large investors.
\end{abstract}




\section{CHAPTER 4 \\ The Profitability Effect of Small and Large Investors' Differential Trading around Management Forecasts}

\subsection{Introduction}

Voluntary disclosures play a significant role in shaping the information environment of a firm. While these disclosures may improve a firm's overall information environment, it is unclear whether different investor groups benefit uniformly. Therefore, we examine how different investor classes utilize a specific type of voluntary disclosure, namely management earnings forecasts. Specifically, we compare the economic consequences of small (naïve) investors' trading decisions to those of large (sophisticated) investors around management forecasts, using earnings announcements as a benchmark. ${ }^{20}$

Our study is motivated by regulatory interest as well as the importance of management forecasts. The Securities and Exchange Commission's (SEC) mission includes the protection of investors and the maintenance of fair capital markets (SEC, 2013). Given the considerable increase in small investors' direct participation in the stock market during the 1990s and their continued high levels of holdings in the 2000s (NYSE, 2000; Barber and Odean, 2002; Ahmed et al., 2003, US Census Bureau, 2012), the SEC is increasingly focused on reducing informational disadvantages often faced by small investors (e.g., SEC, 2009; SEC, 2012). Accordingly, the fairness of capital markets is of immense significance to regulators in their efforts to improve the information environment for 'all' investors. While the large volume of publicly available information may have diminished the information asymmetry between the firm and its investors, it does not necessarily translate to decreased information asymmetry among the firm's investor classes. This raises the question whether voluntary disclosures, which are additional to and different from earnings announcements, provide equal benefits for all investors.

Management earnings forecasts have become pervasive in US capital markets since the mid1990s, and prior research has documented that the information provided in them is, on average, valuable to market participants (Anilowski et al., 2007; Beyer et al., 2010). In addition to their individual importance, management forecasts are also

${ }^{20}$ In the rest of the paper, we use the terms - naïve, retail and small for investors that trade in small quantities. We also use terms such as large, sophisticated for investors who trade in large quantities. 


\section{CHAPTER 4 \\ The Profitability Effect of Small and Large Investors' Differential Trading around Management Forecasts}

important for researchers of investors' trading behavior because management forecasts have different attributes compared to earnings announcements, which may affect the trading behavior of small and large investors differentially at the two announcements, potentially increasing the profitability difference of small and large investors' trading at the management forecast.

Prior studies have used the trading behavior of small and large investors to examine the differential impact of new information on these two broad classes of investors (e.g., Lee, 1992; Bhattacharya, 2001; Bhattacharya et al., 2007; Malmendier and Shanthikumar, 2007; Mikhail et al., 2007; Miller, 2010; Lawrence 2013). These studies document a significant difference in the trading behavior of small and large investors around public - mostly corporate and mandatory - information releases, and conclude that small investors' naïve interpretation of publicly disclosed information leads to unprofitable trading decisions. Taken together this evidence is consistent with the argument that some public disclosures may disadvantage small investors if the costs of extracting useful and unbiased information, in terms of expertise or time, increase. However, the results of differential trading behavior around earnings announcements do not necessarily translate to management forecasts.

Although management earnings forecasts, like earnings announcements, are corporate public disclosures, they differ from the latter in several key attributes. Management forecasts are voluntary and unscheduled, provide timelier, forward-looking and unverifiable information compared to earnings announcements, which are mandatory, scheduled, backward-looking, confirmatory, (more) verifiable, and have a disciplining aspect relating to prior voluntary disclosures and biases (Chae, 2005; Ball and Shivakumar, 2008). Moreover, managerial incentives, biases and firm characteristics influence significantly the firm's decision to issue a forecast, as well as the attributes of the forecast (e.g., Ajinkya et al., 2005, Athanasakou et al., 2011). While based on prior findings on earnings announcements it could be argued that management forecast announcements are expected to generate differential trading among large and small investors, it is not clear whether the difference between small and large investors' trading behavior would remain the same at the management forecast. The difference in 


\section{CHAPTER 4}

The Profitability Effect of Small and Large Investors' Differential Trading around Management Forecasts

information content and reliability of the two announcements, and the unscheduled nature of management forecasts, coupled with lower processing abilities of small investors, may influence the trading decisions of small and large investors differentially around the two announcements. Accordingly, we examine i) whether management forecasts affect the trading behavior of different investor groups at the management forecast date differentially compared to the earnings announcement, and more practically, ii) whether the difference in profitability of small and large investors' trades changes at management forecasts compared to earnings announcements.

Although the different characteristics of voluntary disclosures suggest that they may be associated with differential trading by different investor classes compared to mandatory disclosures, and despite an abundance of research on investors' trading behavior around earnings announcements, the differential trading behavior of different investor classes around management forecasts has not been examined. Furthermore, evidence on the effect of voluntary disclosures on information asymmetry among investors is also scant. While the findings of extant studies on the information asymmetry among investors around management forecasts suggest that information asymmetry among investors is higher around management forecasts than around earnings announcements (Barron et al., 2010; Cho and Kwon, 2014; the study in Chapter 3 of this dissertation), none of these studies can speak to the actual trading behavior of small investors around the management forecast (compared to that of sophisticated investors), or to the potential economic consequences thereof.

We match firms that provide management forecasts with non-forecasting firms using a propensity score methodology to be able to examine the differential effect of management forecasts compared to earnings announcements. Using the Trades and Quotes (TAQ) database, we identify each trade as a buy or a sell based on the Lee and Ready (1991) algorithm to develop our measures of differential trading. We use a differences in differences design in our main empirical tests. This allows us to examine the differences in profitability of small and large investors' trading reactions around management forecasts compared to earnings announcements. 


\section{CHAPTER 4 \\ The Profitability Effect of Small and Large Investors' Differential Trading around Management Forecasts}

We first examine whether the trading behavior of the two classes of investors are different at management forecasts compared to earnings announcements. We find that small investors initiate more buy and sell trades around management forecast announcements than large investors, but the net-buy volume of small and large investors is not different at the forecast date. When comparing the trading behavior of both small and large investors around the management forecast and the earnings announcement, we find that small investors trade proportionately more around earnings announcements, while large investors trade proportionately more around management forecasts. In sum, the trading behavior of small and large investors at the management forecast is different compared to that around the earnings announcement, and the difference in their trading behavior differs at the management forecast compared to earnings announcements.

Next, we test whether the trading behavior differential can be explained by differential trading on different forecast errors. We find that management forecasts influence the trading behavior of small and large investors differentially, because small investors trade in the direction of a random walk forecast error around the management forecast but not around earnings announcements, in contrast with large investors, whose trades are not associated with forecast errors around corporate announcements.

To address our main question of differential trading profitability of investor groups around management forecasts and earnings announcements, we examine whether the differential trading behavior of individual investors compared to large investors advantages or disadvantages them economically at the management forecast announcement compared to the earnings announcement. We find that the difference in profitability between small and large investors' trades is different between earnings announcements and management forecasts. Specifically, small investors lose significantly more on trades around non-forecasting firms' earnings announcements, and they gain significantly more on trades around management forecasts. In sum, management forecasts improve the profitability difference of small investors' trades compared to earnings announcements by reversing a differential loss at the earnings announcement into a differential profit at the management forecast compared to large investors. 


\section{CHAPTER 4 \\ The Profitability Effect of Small and Large Investors' Differential Trading around Management Forecasts}

Additionally, we examine if firm characteristics, such as firm complexity and firm information environment, or the characteristics of the management forecast affect the profitability differential of small investors' trades. We find that the proportion of intangible assets, the volatility of firms' operating income, and firm age do not influence the profitability difference between small and large investors at management forecast and earnings announcements. However, a higher market-to-book ratio increases the profitability differential of small investors' trades at the management forecast compared to the earnings announcement. Surprisingly, small investors' profitability advantage of trading in high-tech firms at the earnings announcement disappears at the management forecast, and similarly, a higher analyst following creates a profitability disadvantage for small investors at management forecasts compared to earnings announcements. Furthermore, large investors seem to take advantage of forecast characteristics to achieve better trading profitability compared to small investors. In sum, firm and forecast characteristics on average, do not help small investors to improve their profitability differential at management forecasts compared to earnings announcements.

Our study makes several contributions to literature. Firstly, we contribute to the information asymmetry literature by examining the information asymmetry among investors directly, and, more importantly, we analyze the practical consequences thereof in terms of differential profitability of investor groups. Prior studies draw conclusions on information asymmetry among investors based on theory, the implicit assumptions of two groups of investors with differing sophistication, and the interpretation of trading volume information, an indirect measure. As a consequence, based on such studies we do not know which investor groups contribute to higher trading volume, and therefore higher information asymmetry, and to what extent. Rather than drawing indirect conclusions about the amount of small and large investors and their informedness, we examine directly the trading behavior of small and large investors. Furthermore, we are also able to study the economic consequences of investor groups' differential trading at the public announcements of companies.

Secondly, our study contributes to the trading literature by documenting that there is a differential trading impact between small and large investors of management 


\section{CHAPTER 4 \\ The Profitability Effect of Small and Large Investors' Differential Trading around Management Forecasts}

guidance compared to earnings announcements, with differential effects on small and large investors' profitability. Specifically, we show that small investors are likely to trade profitably at the management forecast and more profitably than large investors, while they trade unprofitably and more unprofitably than large investors at the earnings announcement. In sum, the comparative losses that small investors make around earnings announcements turn into comparative profitability around management forecasts.

Finally, we add to the voluntary disclosure literature by examining the trading effects and the economic consequences thereof, of trading by small and large investors at the management forecast. We find that management forecasts induce differential trading compared to earnings announcements, as well as between small and large investors, turning small investors' comparative losses at the earnings announcement into comparative profits around management forecasts. However, we also document that small investors are unable to take advantage of more precise management forecasts, unlike large investors who utilize this information in their trades to trade more profitably.

Our study has implications for regulators as well as investors. Our study promotes the SEC's understanding of small investors' use of financial information and trading behavior by providing information about the differential trading behavior of small investors induced by management forecasts. Using their behavior around earnings announcements as a benchmark, we show that small investors trade proportionately less around the management forecast than around earnings announcements. This is in contrast to large investors who trade proportionately more around management forecasts. These findings mean that management forecasts are used less by small investors for trading purposes. The reasons for lower trading on management forecasts by small investors could either be due to lower accessibility or prominence of management forecasts (notwithstanding the efforts of regulators to make all financial information equally accessible to all investors), or the different characteristics of management forecasts that make them less understandable for small investors resulting in reduced motivation to trade. Our main finding however is that compared to comparatively higher losses of small investors at the earnings announcement, small investors achieve a higher comparative profit on their trades at the management forecast. This means that the lower proportion of 


\section{CHAPTER 4 \\ The Profitability Effect of Small and Large Investors' Differential Trading around Management Forecasts}

small investors who trade on management forecast information achieve higher profitability than large investors, and are able to change trading losses around earnings announcements into profits. This finding implies that voluntary disclosures do not disadvantage small investors compared to large ones economically, on the contrary, they help small investors improve the profitability of their trades. On the negative side, our results suggest that firm or forecast characteristics do not help the trading profitability of small investors at the management forecasts; these seem to advantage large investors instead.

This study is also important from investors' perspective. We document that management forecasts make different contributions to trading profits of different investor classes, in comparison to earnings announcements. Specifically, while small investors trade with higher losses at the earnings announcement compared to large investors, they can take advantage of management forecasts to earn higher profits than large investors at the management forecast date.

The paper proceeds as follows. We discuss the motivation and hypothesis development for the study in the next section. Section 3 covers the sample selection, followed by a discussion of our findings in section 4. Section 5 discusses results of additional tests and section 6 concludes.

\subsection{Motivation and Hypothesis Development}

\subsubsection{Regulation}

The Securities and Exchange Commission's (SEC) mission includes the protection of investors and the maintenance of fair capital markets (SEC, 2013). ${ }^{21}$ The SEC has

\footnotetext{
${ }^{21}$ The SEC's mission includes the protection of investors, maintenance of fair, orderly, and efficient markets, and facilitation of capital formation, emphasizing the increasing importance of investor protection over time. This results in the fundamental concept that "all investors, whether large institutions or private individuals, should have access to certain basic facts about an investment prior to buying it, and so long as they hold it", therefore "the SEC requires public companies to disclose meaningful financial and other information to the public. This provides a common pool of knowledge for all investors to use to judge for themselves whether to buy, sell, or hold a particular
} 


\section{CHAPTER 4 \\ The Profitability Effect of Small and Large Investors' Differential Trading around Management Forecasts}

consequently focused on increasing the available information in capital markets ${ }^{22}$ by mandating disclosures and by encouraging firms to increase their voluntary disclosures (e.g., Private Securities Litigation Reform Act, or Safe Harbor Act of 1995). The SEC's premise is that more information benefits investors. Consequently, as long as the firm is not willfully misguiding investors, the SEC assumes that more corporate disclosure is likely to reduce the information asymmetry between the firm's managers and its investors. The SEC's premise that more information benefits investors is consistent with the predictions of economic models that increased disclosures by firms increase liquidity of a firm's stock and decrease its cost of capital (e.g., Diamond and Verrecchia 1991; Kim and Verrecchia 1994). ${ }^{23}$

However, while increasing the volume of publicly available information may decrease the overall information asymmetry between the firm and its investors, it does not necessarily translate into a decrease in the information asymmetry among the firm's investors. To this end the SEC has enacted several regulations to ensure equal access to capital market information for all classes of investors (e.g., Regulation Fair Disclosure, 2000). ${ }^{24}$ Notably, the SEC has continued to expend effort to protect the small investor by leveling the playing field through the reduction of individual investors' informational disadvantages relative to other investor groups (Foster, 1986; Beatty and Hand, 1992; Bhattacharya, 2001).

In contrast to the SEC's original premise that more publicly available information improves the information environment for all investors, it has been argued

security. Only through the steady flow of timely, comprehensive, and accurate information can people make sound investment decisions" (SEC, 2013 under "Introduction").

22 "Ever since the SEC was established in 1934, our approach has been to require companies that wanted to list or trade their securities to comply with initial and continuing disclosure obligations. The goals of this approach are to prevent misleading or incomplete financial reporting and to facilitate informed decisions by investors" (Levitt, 1998c:79).

${ }^{23}$ The SEC's premise is however in contrast with more current theories arguing that more disclosure may not be beneficial from a welfare perspective (e.g., Kanodia, 2007)

${ }^{24}$ In addition to Regulation Fair Disclosure, regulations such as section 501 of the Sarbanes Oxley Act (2002), NASD Rule 2711 (2002), NYSE Rule 472 (2002), Global Settlement, were directed towards reducing the information asymmetry amongst investors by restricting the access of large investment brokers. 


\section{CHAPTER 4 \\ The Profitability Effect of Small and Large Investors' Differential Trading around Management Forecasts}

that too much information may be disadvantageous as well. ${ }^{25}$ Using the trading behavior of small and large investors to examine the differential impact of new information on the two broad classes of investors, recent research suggests that more public disclosure of information may disadvantage retail investors (Bhattacharya et al., 2007; Mikhail et al., 2007; Miller, 2010; Lawrence, 2013). In addition to quantitative changes, qualitative differences may also differentially affect investor groups. Voluntary information, due to its different attributes, may also impede retail investors in making investment decisions, as the different information content of the disclosure could influence the costs of information processing, and ultimately the benefits derived.

The SEC considers understanding individual investors' informational needs “critical to carrying out the Commission's investor protection mission" (SEC, 2012), because of the increasing importance of small investors in capital markets, specifically the tremendous growth in direct and indirect participation of small investors in capital markets in recent years (NYSE, 2000; White, 2014). Despite "its ongoing efforts to help retail investors make informed investing decisions" (SEC, 2012), relatively little is known about how retail investors use financial reporting information for making investment decisions and the success of those decisions (Lawrence, 2013).

\subsubsection{Management Forecasts}

An extensive stream of literature provides empirical evidence on the role of management guidance in a firm's information environment. Management forecast announcements are one of the most significant and pervasive voluntary disclosures in the US capital market. The proportion of forecasting firms has increased from $10 \%$ in the mid1990s to $25 \%$ in 2001-2003, and to 60-80\% in 2006 and 2013 (Anilowski et al., 2007; NIRI, 2006; Rogers and Van Buskirk, 2012; King, 2013). Management forecasts are not only widespread, they are also value relevant; more than half of accounting based information is provided

\footnotetext{
${ }^{25}$ Arthur Levitt made the point that "[i]n many cases, the problem is not a lack of information; quite the opposite. Too much information can be as much a problem as too little. More disclosure does not always mean better disclosure" (Levitt, 1997).
} 


\section{CHAPTER 4 \\ The Profitability Effect of Small and Large Investors' Differential Trading around Management Forecasts}

to investors through management forecasts (Ball and Shivakumar, 2008; Beyer et al., 2010).

Recently however, both the investment community and academics have questioned whether these forecasts are in fact making the average investor better off in the long run (Fuller and Jensen 2002; Jensen et al. 2004; CFA Institute, 2006; Hsieh et al., 2006; Krehmeyer and Orsagh, 2006; U.S. Chamber of Commerce, 2007). While the firm's investors as a group might be supported by management forecasts, there are likely to be differences in the benefits that different investor groups derive from these disclosures, affecting their trading behavior.

Although management earnings forecasts, like earnings announcements, are corporate public disclosures, they differ from earnings announcements in their attributes. Management forecasts are of a voluntary nature, are forward-looking, i.e. they provide timelier information on the expected performance of a firm, and are also unverifiable as a result. In contrast, earnings announcements are mandatory, backward-looking, confirmatory, and have a disciplining aspect relating to prior voluntary disclosures and bias, because of their more verifiable nature (Ball and Shivakumar, 2008). As a consequence, the different information content of management forecasts could be considered more or less reliable by different investor classes compared to the earnings announcement, and motivate different levels of trading around the two announcements.

While earnings announcements are scheduled events, management forecasts, as voluntary disclosures, are unscheduled but can be anticipated by sophisticated investors (Chae, 2005). This might differentially influence investors' information search activities prior to management forecasts and consequently their trading behavior around it.

Moreover, both a manager's decision to issue a forecast as well as forecast attributes can be influenced by managerial incentives (e.g., to manage market expectations and the cost of equity) and biases (e.g., overconfidence, overoptimism) (Hirst et al., 2008; Bamber et al., 2010; Athanasakou et al., 2011). For example, to encourage voluntary forecasting activity, management is protected against any “inadvertent misguidance" (Safe Harbor Act of 1995). Because they are unverifiable in contrast with earnings announcements, managerial incentives and biases can influence 


\section{CHAPTER 4 \\ The Profitability Effect of Small and Large Investors' Differential Trading around Management Forecasts}

management forecasts comparatively more than earnings announcements, differentially affecting the accuracy and reliability of the two types of announcements. This in turn may influence the trading decisions of different investor classes differentially, with the potential result that the profitability difference between small and large investors' trades around earnings announcements changes at the management forecast date.

Furthermore, prior research finds a significant association between disclosure levels and institutional ownership, and documents that firms with greater institutional ownership are more likely to issue management forecasts (Healy et al., 1999; Ajinkya et al., 2005). This evidence is consistent with institutional investors demanding more disclosure; in other words, firms may be catering to institutional investors with the practice of issuing management forecasts, thereby making these forecasts more informative for this group compared to individual investors.

\subsubsection{Trading Decisions}

Prior studies have used the trading behavior of small and large investors to examine the differential impact of new information on the two broad classes of investors (Lee, 1992; Bhattacharya, 2001; Bhattacharya et al., 2007; Mikhail et al., 2007). These studies document a significant difference in the trading behavior of small and large investors around public information releases, and conclude that small investors' naïve interpretation of information leads to unprofitable trading decisions. In particular, Lee (1992) finds that small trades show high buying activity irrespective of the information content of the earnings news. In the same vein, Bhattacharya (2001) also shows that small trades are associated with seasonal random walk (i.e. naïve) earnings expectations. Bhattacharya et al. (2007) document a significant difference in the trading behavior of small and large investors around pro forma earnings announcements and conclude that smaller investors, on average, are easily misled by pro forma information. This differential reaction in trading behavior is not limited to corporate disclosures. Mikhail et al. (2007) examine the trading behavior of small and large investors around analyst recommendations and find that small investors make naïve trading decisions based on analyst recommendations and incur losses. 


\section{CHAPTER 4 \\ The Profitability Effect of Small and Large Investors' Differential Trading around Management Forecasts}

While there is ample evidence on trading around earnings announcements, there is no study that examines investors' differential trading behavior around management forecasts. The study in Chapter 3 of this dissertation provides incidental and indirect evidence by comparing the total trading volume around earnings announcement and management forecasts. She documents a higher trading volume around management forecasts and interprets these results as higher information asymmetry among the investors of a firm. However, information asymmetry among investors is an abstract concept: the interpretation of trading volume results is based on the assumption of trading by investors of both high and low sophistication, but there is no benchmark that would enable the identification of the actual level of sophistication of the investors who are trading or the proportion of the investors who trade around information events. Practically this means that it is not clear whether a higher trading volume around management forecasts results from more trading by small or large investors, or both, and whether the difference in the trading behavior of these two classes of investors is different around the two events.

\subsubsection{Hypothesis Development}

\section{Trading Around Management Forecasts}

Prior research provides empirical evidence on individual investors' use of financial disclosures. Deaves et al. (2006) demonstrate that individuals read and use companies' financial disclosures to make trading decisions. Also, Bushee et al. (2003) document a positive relation between the frequency of small trades and open conference calls. Regulators also try to ensure that small investors have equal access to information (e.g., Regulation Fair Disclosure, 2000). In sum, as do sophisticated investors, individual investors are also likely to trade on any new information related to the firm's valuation, including management forecasts.

Based on small investors' differential trading behavior around other earnings related information events, small investors' (potentially) differential access to information and differential processing abilities, coupled with the differences between 


\section{CHAPTER 4}

The Profitability Effect of Small and Large Investors' Differential Trading around Management Forecasts

earnings announcements and management forecasts, we expect that individual investors trade differently around management guidance as well. Moreover, management forecasts by virtue of their different attributes are likely to affect both small and large investors' behavior, which could result in both investor groups changing their trading behavior the same way. We posit that small investors' different processing abilities coupled with the fundamentally different attributes of management forecasts are likely to induce differential use of the forecast by small and large investors. In other words, the difference in trading behavior of small and large investors observed at the earnings announcement is likely to change at the management forecasts, because of a differential impact of management forecasts on the two investor groups. Nevertheless, we argue that ex-ante it is unclear how the trading behavior of the two classes of investors differs around the two disclosure events. It is unclear i) whether access to management forecasts is in fact different for small investors, ii) which attributes of management forecasts matter more in determining small investors' motivation to trade, and iii) whether these factors intensify or weaken trading activities around management forecasts compared to earnings announcements and compared to large investors' trading. On the one hand, management forecasts may be less accessible to small investors than to large ones and small investors may not be able to efficiently interpret management forecasts, thereby triggering lower trading by small investors. Alternatively, small investors may deem management forecasts to convey more news because these announcements contain forward looking information, and trade more. Likewise, it is an open question how large investors trade around management forecasts compared to earnings announcements. 


\section{CHAPTER 4 \\ The Profitability Effect of Small and Large Investors' Differential Trading around Management Forecasts}

In sum, whether the differences in trading behavior of small and large investors at the management forecast and the earnings announcement are different, as a result of small and large investors' higher or lower trading at the management forecast and at the earnings announcement, is therefore, an empirical question. Accordingly, we test the following hypothesis (in alternate form):

H1: $\quad$ The difference in the trading behavior of small and large investors around management forecasts is different from the difference in trading behavior of small and large investors around earnings announcements.

\section{Profitability of Small Investors' Trades}

Individual investors are less able to filter biases from financial information and therefore are more likely to trade on naïve expectations or biased information, such as randomwalk-based forecast errors, pro forma earnings information, or incentives-influenced analyst recommendations (Bhattacharya, 2001; Bhattacharya et al., 2007; Mikhail et al., 2007). However, it is not clear whether these decisions result in a loss for the small investors around management forecasts. On the one hand, we argue that small investors' limited ability to process information leads to unprofitable trading decisions compared to large investors around any announcement. This argument draws merit from studies that document individual investors' trading decisions around earnings announcements and conclude that they rely on inferior earnings expectation models and prominent, but potentially misleading earnings information (Bhattacharya, 2001; Bhattacharya et al., 2007). In addition, recent empirical evidence documents an increase in the information asymmetry after public announcements, which spur the production of private information (Bamber et al., 2011). Because sophisticated investors are able to generate more private information, their trading decisions are likely to be more profitable compared to small investors. Hence, we conjecture that small investors' limited ability and inefficiency in processing information contained in management forecasts would, on average, result in unprofitable trading decisions compared to large investors around the earnings 


\section{CHAPTER 4 \\ The Profitability Effect of Small and Large Investors' Differential Trading around Management Forecasts}

announcement and the management forecast as well. In addition, we argue that the profitability of small investors' trades is likely to differ between management forecasts and earnings announcements, because of the differences in the two announcements' attributes and the different processing abilities of the two investor groups. But we do not make directional expectations about the differences in profitability of trading by large investors at the management forecast compared to that around earnings announcements. In sum, whether the difference in profitability of the two investor groups' trades are larger at the management forecast, or at the earnings announcement, is an empirical question. Hence our hypothesis is expressed, as follows:

H2: $\quad$ The difference in the profitability of small and large investors trading behavior around management forecasts is different from the difference in profitability of small and large investors' trading behavior around earnings announcements.

\section{Firm Characteristics}

The information environment of a firm plays a significant role in investors' reaction to earnings news. Investors of firms with complex business models face greater difficulty in assessing the effects of current events, and similarly, investors of firms with more complex financial disclosures find it more difficult to process the pricing implications of these disclosures. In turn, the richer a firm's information environment, the smaller the contribution an individual disclosure makes and the easier it is to understand (Waymire 1986; Lang and Lundholm 1993, 1996; Botosan and Plumlee, 2002; Hribar and Yang, 2013). On the one hand, we argue that the voluntary disclosures of less complex firms and firms with richer information environment are easier to understand for small investors, increasing the volume of their trades. On the other hand, less complex firms and firms with richer information environment are likely to be priced more correctly, thereby offering no incentive to invest in these firms, reducing the volume of trades in their stocks. Hence, ex-ante it is not clear whether firm complexity or the richness of the information environment would exacerbate or mitigate the profitability difference of 
individual and large investors' trades at the management forecast compared to the earnings announcement. We formally state these hypotheses below (in alternate form):

H3a: $\quad$ More complex firms affect the profitability difference between small and large investors differentially around management forecasts compared to earnings announcements.

H3b: Firms with richer information environment affect the profitability difference between small and large investors differentially around management forecasts compared to earnings announcements.

\section{Management Forecast Characteristics}

In addition to the effects of the information environment of a firm, prior research documents that small investors on average benefit from standardized, less complex, clearer and more concise disclosures. Small investors' trading increases with disclosures that contain financial information that is easier to understand (Asthana et al., 2004; Miller, 2010; Lawrence, 2013). In sum, empirical evidence suggests that information that is of higher quality or requires less expertise to process, decreases individuals' informational disadvantages and increases their trading activities. Therefore, we expect that forecasts that are easier to understand decrease the profitability difference of small and large investors' trades at the management forecast. The hypothesis is formally stated below (in alternate form):

H4: $\quad$ Management forecasts that are easier to understand decrease the profitability difference between small and large investors around management forecasts. 


\subsection{Sample and Empirical Design}

\subsubsection{Sample}

Our sample period is 2002-2010. In line with the arguments in Rogers and Stocken (2005), we limit our sample to calendar years after 2002 as that year witnessed several major regulations affecting the information environment in securities markets (SarbanesOxley Act, NASD 2711, NYSE 472, Global Settlement).

We use a matched sample of forecasting and non-forecasting firms to test our hypotheses. To develop the two samples we use the First Call Company Issued Guidance (FCCIG)/IBES database. For the sample of forecasting firms we obtain quarterly management earnings forecasts of earnings per common share (EPS), issued for fiscal quarters in 2002 to 2010 . We drop forecasts issued on or after the fiscal-year end to exclude earnings pre-announcements, earnings warnings, and forecasts with erroneous forecast dates. We match the FCCIG/IBES sample with First Call/IBES Actuals for the quarterly earnings announcement date and the annual earnings number. To identify the sample of non-forecasting firms, we start with the First Call Actual database, match it to the FCCIG database, and keep the firm quarters during the years 2002 to 2010 if management has not issued a forecast for the same fiscal period or any subsequent fiscal periods. Then we match the sample with First Call Summary to obtain quarterly analyst forecasts at both the management forecast release date and the earnings announcement date. We exclude observations from both samples with insufficient data in the TAQ, CRSP and Compustat databases needed to compute our variables. The samples prior to propensity score matching are made up of 1,908 forecasting and 3,980 non-forecasting firms, with 20,825 and 47,091 firm-quarter observations, respectively.

\section{Propensity Score Matching}

This study examines the trading volume behavior of small and large investors around both the management forecast and earnings announcement date of forecasting and nonforecasting firms. Because it is likely that firms' voluntary forecasting choice is 


\section{CHAPTER 4}

The Profitability Effect of Small and Large Investors' Differential Trading around Management Forecasts

associated with firm characteristics that also influence investors' trading behavior, we must select our control sample (non-forecasting firms) ensuring that our results are not driven by factors endogenous to the decision to issue a forecast. To control for the selfselection bias of firms issuing voluntary earnings forecasts we use propensity score matching (PSM) to develop a control sample of non-forecasting firm-quarters and include several firm specific attributes closely associated with management's decision to forecast. The PSM method allows the generation of a randomized sample in which the attribute of issuing a voluntary management forecast is randomly distributed across the forecasting and non-forecasting samples (Lawrence et al., 2011). This method ensures that differences in observable characteristics between the forecasting and non-forecasting firm samples are reduced.

We use a logistic regression model to estimate the propensity score, the firmquarter specific probability that a firm issues a quarterly management forecast in a given quarter. In the estimation we use the quarterly forecasting choice as our treatment variable, and include observable variables that could influence investors' trading behavior, the outcome variable (Rosenbaum and Rubin, 1983; Armstrong et al., 2010). We carry out the matching exercise separately for each year-quarter in the sample to ensure that observations are matched from the same fiscal/calendar quarter. Finally, we match forecasting and non-forecasting firm-quarter observations, using the propensity scores, one-on-one, without replacement, using common support, with the smallest propensity score difference.

The model to estimate the propensity score takes the following form (firm and time subscripts are suppressed):

$$
\mathrm{MEF}=\beta_{0}+\beta_{1} \text { Matching variables }+\varepsilon
$$

Where:

$\boldsymbol{M E F}$, the outcome variable, is an indicator variable that equals one if the firm has issued a quarterly management earnings forecast, and zero otherwise. 


\section{CHAPTER 4 \\ The Profitability Effect of Small and Large Investors' Differential Trading around Management Forecasts}

We follow prior studies on the determinants of management forecasts (Barron et al., 2010; Houston et al., 2010; Hribar and Yang, 2013; Rogers and Van Buskirk, 2013) to identify the following Matching variables. Loss firms are less likely to provide earnings guidance, so we include $\boldsymbol{L O S S}$ as an indicator variable, equal to one if the firm reports a loss in the fiscal quarter. Firm size is significantly positively related to the likelihood of forecasting. Hence, we include $\boldsymbol{S I Z E L} \boldsymbol{N}$, defined as the natural logarithm of the total assets of the firm. Also, higher institutional ownership in a firm leads to an increased demand for information. Therefore, we include INST as a measure of institutional holdings. It is calculated as the percentage of outstanding shares held by institutional investors in the quarter. Another important determinant of the firm's likelihood to issue a forecast is whether it is a value or a growth firm. We include the market-to-book ratio, $\boldsymbol{M T B}$, calculated as the ratio of market-to-book value of the firm's common equity at the end of the fiscal quarter. We also include $\boldsymbol{R} \boldsymbol{O} \boldsymbol{A}$, Return on Assets, measured as quarterly net income divided by total assets.

Analysts play a significant role in shaping the information environment of a firm. Hence, we include several analyst forecast related variables (calculated using analyst forecasts outstanding prior to the quarterly earnings announcement). These include NUMEST, the number of analyst forecasts; STDEV, the standard deviation of the outstanding analyst forecasts to measure the dispersion in beliefs prior to the

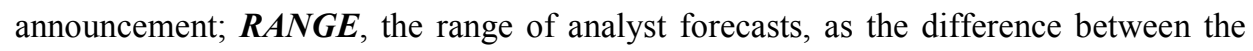
highest and lowest analyst forecast, scaled by the mean analyst forecast.

We also include the stock return volatility, RETVOL, calculated as the standard deviation of daily stock returns over the 253 trading days prior to the quarterly earnings announcement; issuance of shares, ISSUE, an indicator variable, equal to one if the firm has issued shares in the quarter. We also match by the proportion of high-tech firms, therefore we include an indicator variable if the firm is in a high-tech industry. HTECH, an indicator variable is equal to one if the firm is a member of an industry with the following four-digit SIC codes: 2833-2836 (Drugs), 8731-8734 (R\&D Services), 73717379 (Software), 3570-3577 (Computers), 3600-3674 (Electronics), 3810-3845 (Instruments), and zero otherwise. 


\section{CHAPTER 4 \\ The Profitability Effect of Small and Large Investors' Differential Trading around Management Forecasts}

Next, we include accounting information related variables: Auditors play a significant role in the accounting information quality. Hence, we include auditor type, $\boldsymbol{A U D}$, an indicator variable equal to one if the firm is audited by one of the "Big4" auditing firms, and zero otherwise; leverage, $\boldsymbol{L E} \boldsymbol{V}$, calculated as total debt over total assets in the quarter; acquisition, $\boldsymbol{A C Q}$, an indicator variable, equal to one if the firm has reported mergers \& acquisitions activities in excess of $10 \%$ of total assets in the quarter; audit opinion, $\boldsymbol{A O}$, an indicator variable equal to one if the firm has received a qualified or adverse audit opinion in the fiscal year, and zero otherwise; material weakness, $\boldsymbol{W E} \boldsymbol{A} \boldsymbol{K}$, an indicator variable equal to one if the firm has reported an internal control material weakness in the fiscal year, and zero otherwise.

Finally, we include industry fixed effects based on the Fama and French (1997) 48 industry classification, but no quarter- and year-fixed effects because of the yearquarter based matching process.

Following the propensity score matching to control for potential selection bias relating to the issue of voluntary management forecasts, the matched sample is made up of 6,466 firm-quarter observations for 1,326 forecasting and 2,090 non-forecasting firms, each.

\subsubsection{Empirical Design}

\section{Trading Variables}

We obtain all NYSE, AMEX, NASDAQ, or regional exchange intraday transactions data from the TAQ database. In line with Bhattacharya et al. (2007), we only use observations of the 'regular sales' condition. ${ }^{26}$ We infer trade direction using the tick rule (Lee and Ready, 1991; Lee, 1992; Bhattacharya et al., 2007) and infer whether the investor is small or large from trade size, over a 3-day event window. The tick rule classifies each trade as buyer- or seller-initiated in continuous auction markets by comparing the price of the

\footnotetext{
${ }^{26}$ The regular sales condition includes "trades [that] result from continuous two-sided auctions involving market orders, limit orders and buys and sells against the specialists' inventories", and exclude trades such as "large block trades or stopped orders" (Bhattacharya et al., 2007:587).
} 


\section{CHAPTER 4 \\ The Profitability Effect of Small and Large Investors' Differential Trading around Management Forecasts}

trade with the price of the preceding trade(s). Each trade is identified as an uptick, downtick or zero tick if the price of the current trade is higher, lower or the same compared to the immediate prior trade, respectively. If the trade is classified as a zero tick, we further classify the tick based on the last price change; if that was an uptick (downtick), then we classify the zero tick as a zero-uptick (zero-downtick). Finally, we classify a trade as a buy (sell) if it is an uptick (downtick) or a zero-uptick (zerodowntick). Although a number of improvements have been suggested to the tick rule (e.g., Lee, 1992; Ellis et al., 2000) we use the tick rule, because of its simplicity, compared to the alternatives, and further, because the studies using improved versions of the method in the empirical market microstructure/trading behavior literature report minor or statistically insignificant improvement in accuracy over the tick method (e.g., Ellis et al., 2000; Bhattacharya, 2007).

In line with prior research, we infer from the trade size whether the investor is small or large (Cready 1988; Lee 1992; Lee and Radhakrishna 2000; Asthana et al., 2004). There are multiple methods used in the literature to classify trades as small and large. Cready (1988) and Cready and Mynatt (1991) use the number of shares traded, specifically 900 shares as the cutoff for large investors. To circumvent identification problems related to share price changes, Lee (1992) suggests a firm-specific dollar valuebased cutoff, adjusted with share price-based round lots of shares traded. Lastly, Bhattacharya et al. (2007) use pure dollar value based cutoffs, after the elimination of shares with very high $(\$ 500<)$ and very low prices $(<\$ 1)$. While most empirical studies using both or multiple methods report that their results are insensitive to the method selected (e.g., Mikhail et al., 2007), Lee and Radhakhrisna (2000) find that the dollar value of trades is a better identifier of small and large investors than the number of shares traded. Therefore, we use the dollar value of shares traded to identify small and large investors. We consider $\$ 10,000$ and $\$ 50,000$ as the cutoffs for small and large trades, respectively. In line with the literature and to test the robustness of our results, we employ several alternative cutoffs: $\$ 5,000$ and $\$ 7,000$ for small, and $\$ 30,000, \$ 40,000$, and $\$ 100,000$ for large trades (e.g., Bhattacharya et al., 2007; Mikhail et al., 2007). 


\section{CHAPTER 4}

The Profitability Effect of Small and Large Investors' Differential Trading around Management Forecasts

We use a 3-day event window $(-1$ to +1$)$ in line with trading behavior and trading volume studies (e.g., Bamber et al., 1997; Barron et al., 2005; Ahmed and Schneible, 2007; Bhattacharya et al., 2007; Bamber et al., 2011). We rely on the observations showing that large investors' trades follow announcements closely, small investors' trades are more dispersed in the few days following the announcement, but $95 \%$ of abnormal trading by both small and large investors occurs within 3 days after the announcement (Cready, 1988; Lee, 1992).

\section{Design for Hypothesis 1}

Hypothesis 1 examines whether the difference in the trading behavior of small and large investors differs around the management forecasts and earnings announcements. To test this hypothesis, we use a difference-in-difference mean comparison: we compare the difference in means of small and large investors' trading variables at the management forecast date to that at the earnings announcement date. We calculate the following variables:

$\boldsymbol{S M L} B \boldsymbol{B} 3\left(\boldsymbol{L} \boldsymbol{R} \boldsymbol{G}_{-} \boldsymbol{B} 3\right)=$ total value of small (large) buy trades, divided by the total value of buy trades in the 3-day event window $(-1$ to +1$)$ around an announcement.

SML_S3 $\left(\boldsymbol{L R} \boldsymbol{R} \_S 3\right)=$ total value of small (large) sell trades, divided by the total value of sell trades in the 3-day event window $(-1$ to +1$)$ around an announcement.

SML_T3 $\left(\boldsymbol{L R} \boldsymbol{G}_{-} \boldsymbol{T} 3\right)=$ total value of small (large) trades (buy plus sell trades), divided by the total value of trades in the 3-day event window $(-1$ to +1$)$ around an announcement.

$S M L \_N 3\left(L R G \_N 3\right)=$ total value of small (large) raw net-buys (buy less sell trades), scaled by the total raw net-buys in the 3-day event window (-1 to +1$)$ around an announcement.

SML_NB3 $\left(\boldsymbol{L} R \boldsymbol{G}_{-} \boldsymbol{N B 3}\right)=$ abnormal small (large) net-buy volume in the 3-day event window $(-1$ to +1$)$ around an announcement. We calculate the abnormal net order imbalance measures for small and large investors following Bhattacharya et al. (2007). Small (large) investors' daily abnormal net-buy volume (buy minus sell volume), is defined as the difference between small (large) investors' daily net-buy volume for firm 
$i$ less small (large) investors' mean daily non-announcement period net-buy volume for firm $i$, scaled by the mean daily non-announcement period total trading volume for firm $i$ :

$$
\begin{aligned}
& \text { Daily net-buy Mean daily non-announcement } \\
& \text { volume for firm i } \quad-\text { period net-buy volume for firm }
\end{aligned}
$$

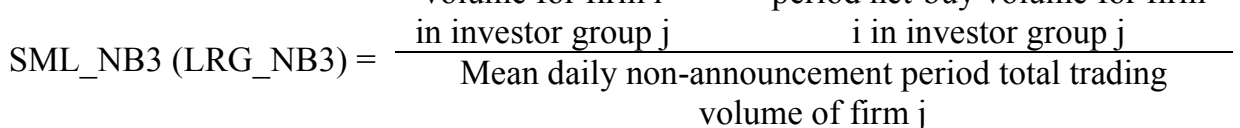

Where, the non-announcement period is the two-week (10 trading days) period ending one month (20 trading days) before the event date. Therefore, abnormal net-buy volumes are defined as small (large) investors' daily abnormal net-buy volumes, aggregated over a 3-day period around the announcements.

To investigate the differences in trading behavior we follow Bhattacharya et al. (2007) and regress random walk and analyst forecast-based forecast errors on small and large investors' abnormal net-buy volumes around the announcements, and estimate the following empirical model (subscripts suppressed):

$$
\begin{aligned}
\text { Abnormal net-buy volume }= & \beta_{0}+\beta_{1} \text { FER }+\beta_{2} \text { FEA }+\beta_{3} \text { CAR }+\beta_{4} \text { SIZE } \\
& +\beta_{5} \text { MKTVOL }+\beta_{6} \text { BUNDLED }+\varepsilon
\end{aligned}
$$

Where:

\footnotetext{
Abnormal net-buy volume $=$ SML_NB3 or LRG_NB3, defined earlier;

$\mathrm{FER}=$ signed random walk forecast error;

$\mathrm{FEA}=$ signed analyst forecast-based forecast error;

$\mathrm{CAR}=$ cumulative abnormal return in the event-window;
$\mathrm{SIZE}=$ natural logarithm of the market value of equity five days prior to the event;

MKTVOL $=$ market-wide trading volume in 3-day event window $(-1$ to +1$)$ around an announcement;
} 


\section{CHAPTER 4 \\ The Profitability Effect of Small and Large Investors' Differential Trading around Management Forecasts}

BUNDLED = indicator variable for bundled management forecasts and earnings announcements.

To examine small and large investors' reactions to the disclosure, we follow Bhattacharya et al. (2007) and use two earnings expectations, a random-walk and analyst forecast

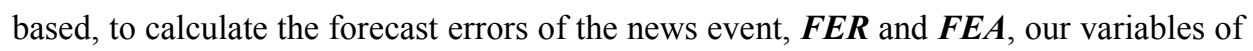
interest. We calculate the random walk forecast error, FER, for earnings announcements as the difference between actual Compustat EPS and a seasonal random-walk expectation, the Compustat EPS from the same quarter of the previous year. The analyst forecastbased forecast error, FEA, is calculated as the difference between IBES actual EPS and the mean of all analyst forecasts made within 90 days of the event. We scale forecast errors with the share price 5-days prior to the event date.

To calculate the forecast errors for management forecasts, we use FCCIG management forecasts in the place of actual EPS values. ${ }^{27}$ Management earnings forecasts of the FCCIG database are classified by specificity into point, range, openended, confirming or qualitative forecasts. We keep all forecasts where a point forecast can be estimated and calculate the value of the forecast in line with prior literature

\footnotetext{
${ }^{27}$ As explained by Rogers and Van Buskirk (2013) recently the majority of management forecasts are bundled with earnings announcements. Relying on the conventional method of management forecast error calculation (MEF minus AF) introduces noise into the forecast news and potentially biases the study's inferences, because the pre-earnings analyst estimate is likely to be stale and systematically biased. The most important sources of this potential bias are (1) the fact that analysts usually withhold their forecasts prior to earnings announcements, therefore the analyst forecasts outstanding immediately prior to the management forecast are likely to be stale; (2) initial optimistic levels and the general walk-down of analyst forecasts the forecast revisions are systematically negative following the earnings announcement, implying that the analyst forecasts outstanding prior to management forecasts are systematically optimistic; (3) positive persistence of earnings innovations. We argue that this forecast error bias is likely to be small/insignificant in our study for two reasons: First, we have a wide pool of non-stale management forecasts, i.e. with analyst forecasts within 45 days prior to the management forecasts. Second, we expect to see effects for the seasonal random walk forecast errors for small traders and no effects for large traders, we do not expect to see effects for small traders for the analyst-forecast-based forecast error, i.e. not being able to show that large traders trade around biased or adjusted analyst-forecast-based forecast errors is a secondary concern.
} 


\section{CHAPTER 4 \\ The Profitability Effect of Small and Large Investors' Differential Trading around Management Forecasts}

(Baginski et al., 1993; Hirst et al., 1999; Rogers and Stocken, 2005; Hutton and Stocken, 2007). ${ }^{28}$

We use the cumulative abnormal return in the event-window, $\boldsymbol{C A R}$, the natural logarithm of the market value of equity, $\boldsymbol{S I Z E}$, and market-wide trading volume, MKTVOL, as control variables in line with prior research (Bamber et al., 1997; Bhattacharya et al., 2007). While our dependent variables, SML_NB3 and LRG_NB3, control for firm-specific liquidity trading by construct, MKTVOL is included in the regression to control for investors' average trading response associated with market-wide and/or macroeconomic factors. MKTVOL is calculated as the percentage of all NYSE/AMEX/NASDAQ firms' outstanding shares traded, over the 3-day event window.

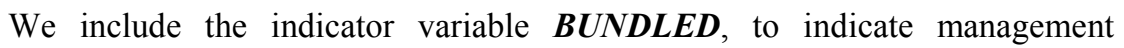
forecasts(earnings announcements) that are bundled with earnings announcements (management forecasts) to be able to identify the differing investor behavior, if any, to bundled announcements. Anilowski et al. (2007) and Rogers and Van Buskirk (2013) show that the proportion of bundled forecasts increases from $10 \%$ in the mid1990s to $80 \%$ by the mid2000s. Similarly the proportion of bundled earnings announcements increases from $1 \%$ to $30 \%$ over the same period (Rogers and Van Buskirk, 2013). Rogers and Van Buskirk (2013) document that there is a significant difference between the characteristics of bundled and non-bundled forecasts. Because bundled forecast represent the majority of management forecast population (and a significant portion of earnings announcements), generalizing results from non-bundled management forecasts (and unbundled earnings announcements) that would provide a cleaner setting for tests is problematic. Therefore, in this study we use both bundled and non-bundled forecasts as well as bundled and non-bundled earnings announcements. BUNDLED is defined as 1 for bundled announcements and 0 for unbundled announcements.

\footnotetext{
${ }^{28}$ For point forecasts we use the forecast value explicitly provided by the firm. For range forecasts we use the midpoint of the range provided by the firm unless statements by management indicate that earnings per share would be at the low (high) end of the range, in which case we use the low (high) end of the range. In addition to point and range forecasts we also use open-ended (open interval, maximum and minimum) and non-point confirming forecasts. For open-ended forecasts and open-ended confirming forecasts, we use the endpoint (upper or lower bound) given by the firm or 0 if the forecast is determined in comparison to 0 . We exclude qualitative forecasts.
} 
We expect a positive coefficient on the random walk forecast error, FER, in small investors' regressions, and similarly, a positive coefficient on the analyst forecastbased forecast error, FEA, in large investors' regressions in line with Bhattacharya et al. (2007).

\section{Design for Hypothesis 2}

Hypothesis 2 tests whether the difference in profitability between small and large investors' trades differs around management forecasts compared to earnings announcements. We test the hypothesis by estimating the following empirical model (subscripts suppressed):

$$
\begin{aligned}
\operatorname{ACAR}= & \beta_{0}+\beta_{1} \mathrm{SML} \_\mathrm{NB} 3+\beta_{2} \mathrm{LRG} \_\mathrm{NB} 3 \\
& +\beta_{3} \mathrm{CAR}+\beta_{4} \mathrm{BCAR}+\beta_{5} \mathrm{SIZE}+\beta_{6} \mathrm{BUNDLED}+\varepsilon
\end{aligned}
$$

Where:

$\mathrm{ACAR}=$ cumulative abnormal return in the period following the event-window; $\mathrm{BCAR}=$ cumulative abnormal return in the 15 days preceding the eventwindow;

Our dependent variable, the cumulative abnormal return in the period following the eventwindow, $\boldsymbol{A C A R}$, proxies for the profitability of investors' trades. We specify the period length for ACAR at 15-, 30-, 60-, 90-, 180-, and 360-days. We regress small and large investors' net-buy volumes (SML_NB3 and LRG_NB3) on the future cumulative abnormal return of their trades (ACAR) to measure the profitability of small and large investors' trades executed in the event-window in subsequent periods. By doing so we capture the consequence of investors' buy and sell trades: the profitability of their trades in subsequent periods. CAR and BCAR are included to control for the serial correlation in returns, while SIZE and BUNDLED control for differential returns related to firm size and announcement bundling. 


\section{CHAPTER 4 \\ The Profitability Effect of Small and Large Investors' Differential Trading around Management Forecasts}

To test the hypothesis we compare the difference of $\beta_{1}$ and $\beta_{2}$, the coefficients of small and large investors' abnormal net-buy volumes, respectively, in the regressions at the management forecast to those at the earnings announcement.

\section{Design for Hypothesis 3}

We test hypotheses H3a and H3b by examining the effect of firm-specific attributes, such as firm complexity and firm information environment on the profitability of investors' trades. We include variables that proxy for firm complexity (more complex financial disclosures and more complex business models): We include the proportion of intangible assets, INTAN, measured as the percentage of recorded intangible assets, as a measure of the complexity of financial information in the firm's disclosures. This is based on the argument that the financial disclosures of firms with frequent and/or large financial transactions (mergers, acquisitions, and divestitures) are likely to be more complex (Barth et al., 2001; Bushee et al. 2003). We include the membership in high technology industries, $\boldsymbol{H T E C H}$, because firms in high technology industries frequently experience rapid change and innovations, and consequently have more complex financial disclosures increasing the difficulty of valuing the firm (Lev and Zarowin, 1999; Bushee et al., 2003; Ahmed and Schneible, 2007). In line with Bushee et al. (2003) we use an indicator for

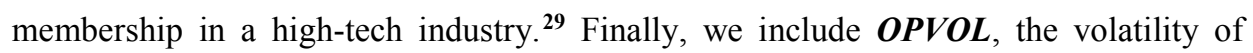
operating performance, because larger unpredictability in a firm's business model is likely to be reflected in the volatility of its operating performance (Bushee et al., 2003). In line with Bushee et al. (2003) OPVOL is measured as the standard deviation of the firm's seasonally differenced quarterly revenue over the past 16 months.

Following prior literature (Bamber, 1987; Atiase and Bamber, 1994; Utama and Cready, 1997; Bushee et al., 2003; Choi et al., 2010; Hribar and Yang, 2013), we use the

\footnotetext{
${ }^{29}$ SIC codes classified as high-tech include: Drugs (2833-2836); Electric Distribution Equipment (3612-3613); Electrical Industrial Apparatus (3621-3629); Household Audio \& Video Equipment (3651-3652), Communications Equipment (3661-3669); Electron Tubes (3671); Printed Circuit Boards (3672); Semiconductors \& Related Devices (3674); Magnetic and Optical Recording Media (3695); Telephone Communications (4812-4822); Radio \& TV Broadcasting (4832-4899); Computer and Data Processing Services (7370-7379).
} 


\section{CHAPTER 4 \\ The Profitability Effect of Small and Large Investors' Differential Trading around Management Forecasts}

following variables to proxy for firms information environment: firm size, $\boldsymbol{S I Z E}$, analyst following, NUMEST, the age of the firm, $\boldsymbol{A G E}$, and the market-to-book ratio, MTB. We include the natural logarithm of the market value of equity, SIZE, to measure firm size (e.g., Bamber, 1987; Atiase and Bamber, 1994; Utama and Cready, 1997; Choi et al., 2010; Hribar and Yang, 2013). The more analysts follow the firm, the more private information is available for investors (Bushee et al., 2003). Therefore, we include analyst following, denoted NUMEST, measured as the number of analysts following the firm on the day of the management forecast. AGE, age of the firm is calculated as the difference between the year of the announcement date and the year of the IPO of the firm. The more informative the financial statements, the more information available for investors. We use the book-to-market ratio, MTB, to proxy for financial statement informativeness based on the argument that the lower the book-to-market ratio, the more difficult it is to assess the valuation implications of the firm's mandatory disclosures (Bushee et al., 2003).

We include these variables in Model (3) and interact them with small and large investors' net-buy volumes (SML_NB3 and LRG_NB3). Then we compare the coefficient differential on the interaction terms of small and large investors' trading at the management forecast to that at the earnings announcement.

\section{Design for Hypothesis 4}

To test Hypothesis 4 we develop forecast characteristic variables that proxy for the ease of understanding the forecasts. Baginski et al. (1993) explain that the specificity of management forecasts is used by management to communicate their uncertainty about their firm's earnings prospects. Forecast specificity is also associated with the ease of understanding the disclosure, that is, an imprecise disclosure will cause more uncertainty in terms of translating the information towards firm valuation. In addition, forecast timeliness plays a considerable role in a management guidance's usefulness: the earlier the firm issues a forecast compared to the earnings announcement date, the greater the earnings uncertainty of an investor, thereby the more difficulty to interpret (e.g., Choi and Ziebart, 2004; Roger and Stocken, 2005; Hutton and Stocken, 2007; Choi et al., 2010; Hribar and Yang, 2013). To proxy for the (im)precision of the forecast with regard to the 
level of earnings uncertainty We follow Baginski et al. (1993) to proxy for earnings uncertainty and measure forecast precision using a categorical variable, denoted $\boldsymbol{S P E C}$, that equals zero for point forecasts, one for range forecasts, and two for open-ended forecasts. We include the length of forecast horizon, HORIZON, defined as the number of days between the forecast date and the firm's fiscal year-end (Rogers and Stocken, 2005). We include these variables into Model (3) at the management forecast date and interact them with small and large investors' net-buy volumes (SML_NB3 and LRG_NB3). Then we examine the coefficient differential on the interaction terms of small and large investors' trading at the management forecast.

\subsection{Results}

\subsubsection{Descriptive Statistics}

Table 4.1 depicts the distribution of forecasting and non-forecasting firms in the full, unmatched sample. There is a total of 20,825 $(47,091)$ firm-quarters with (without) management forecasts in our sample years of 2002-2010. Descriptive statistics show that in the unmatched, full sample, forecasting firms differ from non-forecasting firms. 
CHAPTER 4

The Profitability Effect of Small and Large Investors' Differential Trading around Management Forecasts

Table 4.1 - Descriptive Statistics of Full Sample

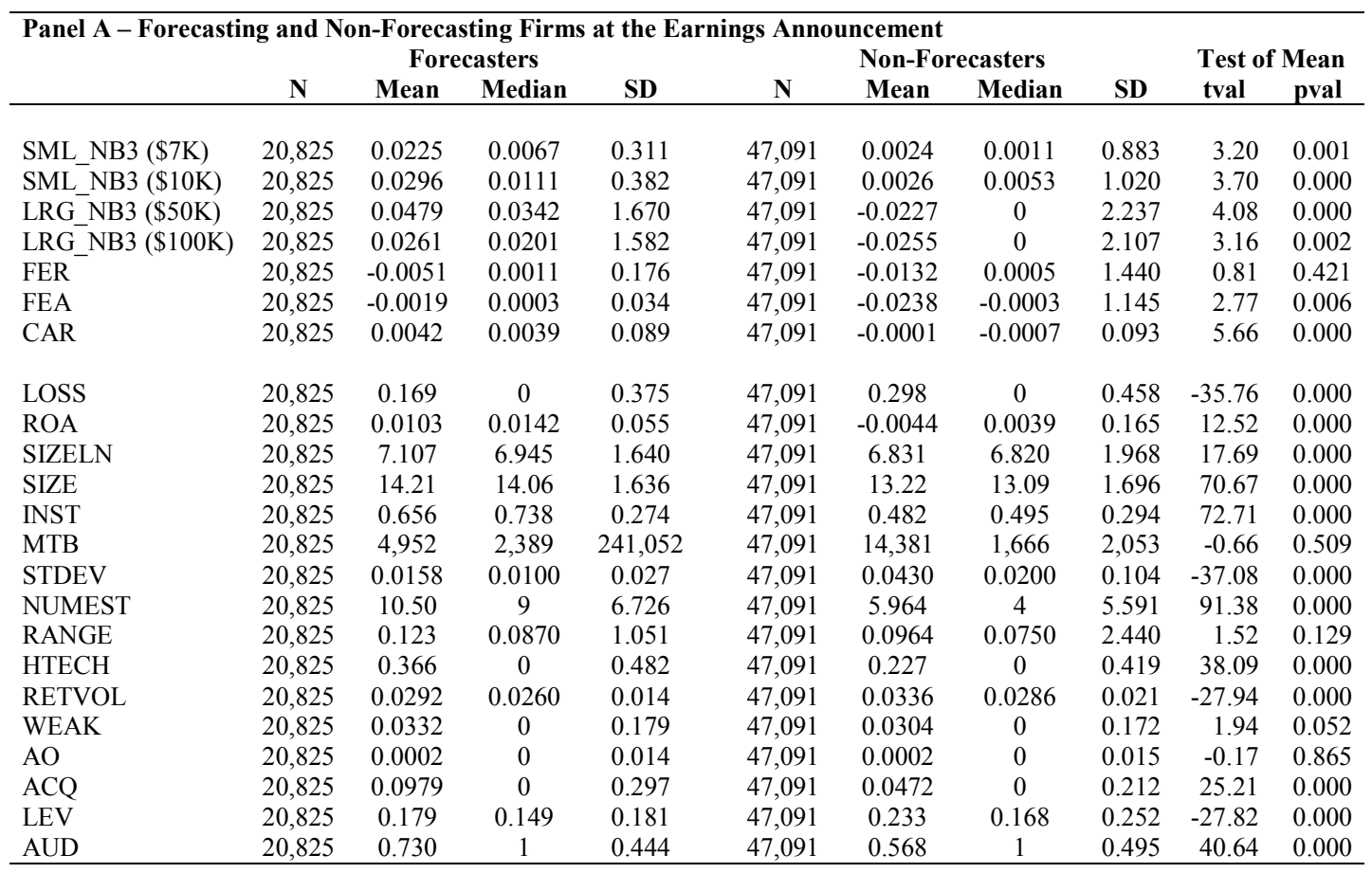


The Profitability Effect of Small and Large Investors' Differential Trading around Management Forecasts

Table 4.1 - Descriptive Statistics of Full Sample (contd)

\begin{tabular}{|c|c|c|c|c|c|c|}
\hline \multicolumn{7}{|c|}{ Panel B - Number of Observations per Fiscal Year } \\
\hline \multirow[t]{2}{*}{ Fiscal year } & \multicolumn{2}{|c|}{ Non-Forecasting } & \multicolumn{2}{|c|}{ Forecasting } & \multicolumn{2}{|c|}{ Full sample } \\
\hline & $\mathrm{N}$ & $\%$ & $\mathrm{~N}$ & $\%$ & $\mathrm{~N}$ & $\%$ \\
\hline 2001 & 2,097 & 4.45 & 1,208 & 5.80 & 3,305 & 4.87 \\
\hline 2002 & 2,745 & 5.83 & 2,157 & 10.36 & 4,902 & 7.22 \\
\hline 2003 & 2,993 & 6.36 & 2,251 & 10.81 & 5,244 & 7.72 \\
\hline 2004 & 3,644 & 7.74 & 2,511 & 12.06 & 6,155 & 9.06 \\
\hline 2005 & 4,321 & 9.18 & 2,342 & 11.25 & 6,663 & 9.81 \\
\hline 2006 & 4,959 & 10.53 & 2,398 & 11.52 & 7,357 & 10.83 \\
\hline 2007 & 5,706 & 12.12 & 2,228 & 10.70 & 7,934 & 11.68 \\
\hline 2008 & 6,341 & 13.47 & 2,084 & 10.01 & 8,425 & 12.41 \\
\hline 2009 & 7,069 & 15.01 & 1,838 & 8.83 & 8,907 & 13.11 \\
\hline 2010 & 7,216 & 15.32 & 1,808 & 8.68 & 9,024 & 13.29 \\
\hline Total & 47,091 & 100 & 20,825 & 100 & 67,916 & 100 \\
\hline \multicolumn{7}{|c|}{ Panel C - Number of Observations per Quarter } \\
\hline \multirow[t]{2}{*}{ Fiscal quarter } & \multicolumn{2}{|c|}{ Non-Forecasting } & \multicolumn{2}{|c|}{ Forecasting } & \multicolumn{2}{|c|}{ Full sample } \\
\hline & $\mathrm{N}$ & $\%$ & $\mathrm{~N}$ & $\%$ & $\mathrm{~N}$ & $\%$ \\
\hline 1 & 13,122 & 27.87 & 5,082 & 24.40 & 18,204 & 26.80 \\
\hline 2 & 12,421 & 26.38 & 5,355 & 25.71 & 17,776 & 26.17 \\
\hline 3 & 12,192 & 25.89 & 4,782 & 22.96 & 16,974 & 24.99 \\
\hline 4 & 9,356 & 19.87 & 5,606 & 26.92 & 14,962 & 22.03 \\
\hline Total & 47,091 & 100 & 20,825 & 100 & 67,916 & 100 \\
\hline
\end{tabular}


Table 4.1 - Descriptive Statistics of Full Sample (contd)

\begin{tabular}{|c|c|c|c|c|c|c|}
\hline \multirow[t]{2}{*}{ Industry } & \multicolumn{2}{|c|}{ Non-Forecasting } & \multicolumn{2}{|c|}{ Forecasting } & \multicolumn{2}{|c|}{ Full sample } \\
\hline & $\mathrm{N}$ & $\%$ & $\mathrm{~N}$ & $\%$ & $\mathrm{~N}$ & $\%$ \\
\hline Agriculture & 70 & 0.15 & 20 & 0.10 & 90 & 0.13 \\
\hline Food Products & 439 & 0.93 & 157 & 0.75 & 596 & 0.88 \\
\hline Candy \& Soda & 78 & 0.17 & 28 & 0.13 & 106 & 0.16 \\
\hline Beer \& Liquor & 113 & 0.24 & 36 & 0.17 & 149 & 0.22 \\
\hline Tobacco Products & 19 & 0.04 & 10 & 0.05 & 29 & 0.04 \\
\hline Recreation & 226 & 0.48 & 65 & 0.31 & 291 & 0.43 \\
\hline Entertainment & 618 & 1.31 & 188 & 0.90 & 806 & 1.19 \\
\hline Printing \& Publishing & 101 & 0.21 & 262 & 1.26 & 363 & 0.53 \\
\hline Consumer Products & 289 & 0.61 & 411 & 1.97 & 700 & 1.03 \\
\hline Apparel & 225 & 0.48 & 346 & 1.66 & 571 & 0.84 \\
\hline Healthcare & 459 & 0.97 & 144 & 0.69 & 603 & 0.89 \\
\hline Medical Equipment & 1,057 & 2.24 & 810 & 3.89 & 1,867 & 2.75 \\
\hline Pharmaceutical Products & 3,977 & 8.45 & 495 & 2.38 & 4,472 & 6.58 \\
\hline Chemicals & 768 & 1.63 & 428 & 2.06 & 1,196 & 1.76 \\
\hline Rubber \& Plastic Products & 183 & 0.39 & 125 & 0.60 & 308 & 0.45 \\
\hline Textiles & 73 & 0.16 & 76 & 0.36 & 149 & 0.22 \\
\hline Construction Materials & 663 & 1.41 & 270 & 1.30 & 933 & 1.37 \\
\hline Construction & 302 & 0.64 & 178 & 0.85 & 480 & 0.71 \\
\hline Steel Works & 620 & 1.32 & 281 & 1.35 & 901 & 1.33 \\
\hline Fabricated Products & 70 & 0.15 & 24 & 0.12 & 94 & 0.14 \\
\hline Machinery & 909 & 1.93 & 953 & 4.58 & 1,862 & 2.74 \\
\hline Electrical Equipment & 505 & 1.07 & 176 & 0.85 & 681 & 1.00 \\
\hline Automobiles \& Trucks & 655 & 1.39 & 171 & 0.82 & 826 & 1.22 \\
\hline Aircraft & 153 & 0.32 & 49 & 0.24 & 202 & 0.30 \\
\hline Shipbuilding, Railroad Equip. & 77 & 0.16 & 21 & 0.10 & 98 & 0.14 \\
\hline Defense & 53 & 0.11 & 14 & 0.07 & 67 & 0.10 \\
\hline Precious Metals & 319 & 0.68 & & & 319 & 0.47 \\
\hline Non-Metallic \& Ind. Metal Mining & 206 & 0.44 & 45 & 0.22 & 251 & 0.37 \\
\hline Coal & 140 & 0.30 & 51 & 0.24 & 191 & 0.28 \\
\hline Petroleum \& Natural Gas & 3,570 & 7.58 & 335 & 1.61 & 3,905 & 5.75 \\
\hline
\end{tabular}




\section{CHAPTER 4}

The Profitability Effect of Small and Large Investors' Differential Trading around Management Forecasts

\begin{tabular}{|c|c|c|c|c|c|c|}
\hline Utilities & 861 & 1.83 & 164 & 0.79 & 1,025 & 1.51 \\
\hline Communication & 2,016 & 4.28 & 283 & 1.36 & 2,299 & 3.39 \\
\hline Personal Services & 332 & 0.71 & 316 & 1.52 & 648 & 0.95 \\
\hline Business Services & 3,403 & 7.23 & 3,759 & 18.05 & 7,162 & 10.55 \\
\hline Computers & 966 & 2.05 & 1,396 & 6.70 & 2,362 & 3.48 \\
\hline Electronic Equipment & 2,689 & 5.71 & 2,141 & 10.28 & 4,830 & 7.11 \\
\hline Measuring \& Control Equipment & 504 & 1.07 & 773 & 3.71 & 1,277 & 1.88 \\
\hline Business Supplies & 448 & 0.95 & 304 & 1.46 & 752 & 1.11 \\
\hline Shipping Containers & 82 & 0.17 & 96 & 0.46 & 178 & 0.26 \\
\hline Transportation & 1,680 & 3.57 & 493 & 2.37 & 2,173 & 3.20 \\
\hline Wholesale & 810 & 1.72 & 579 & 2.78 & 1,389 & 2.05 \\
\hline Retail & 1,491 & 3.17 & 2,847 & 13.67 & 4,338 & 6.39 \\
\hline Restaurants, Hotels, Motels & 502 & 1.07 & 602 & 2.89 & 1,104 & 1.63 \\
\hline Banking & 7,782 & 16.53 & 328 & 1.58 & 8,110 & 11.94 \\
\hline Insurance & 2,258 & 4.79 & 238 & 1.14 & 2,496 & 3.68 \\
\hline Real Estate & 195 & 0.41 & 38 & 0.18 & 233 & 0.34 \\
\hline Trading & 3,753 & 7.97 & 192 & 0.92 & 3,945 & 5.81 \\
\hline Other & 382 & 0.81 & 107 & 0.51 & 489 & 0.72 \\
\hline Total & 47,091 & 100 & 20,825 & 100 & 67,916 & 100 \\
\hline
\end{tabular}

Table 4.2 Panel A shows the success of propensity score matching: the differences in various firm characteristics of the forecasting and non-forecasting firms after matching. We do not find any significant differences in the two subsamples on most matching variables. The results indicate however that forecasting firms are larger, have lower institutional ownership, higher analyst following and higher stock return volatility. We also document that in terms of the regression variables the trading behavior of small investors is significantly different for forecasting and non-forecasting firms, and that forecasting firms differ in their random walk forecast error. Table 4.2 Panels C and D show that, due to the fiscal year and fiscal quarter based matching process, the distribution of firm-quarter observations is more balanced between forecasting and non-forecasting firms in the matched sample. Unlike the unmatched samples, the number of firm-quarters 
CHAPTER 4

The Profitability Effect of Small and Large Investors' Differential Trading around Management Forecasts

increases to and peaks in 2008, while the number of observations of the second quarter are higher, and the fourth quarter are lower than that in the other two. Table 4.2 Panel E shows that firms are more evenly distributed among industries compared to the unmatched sample.

Table 4.2 - Descriptive Statistics of Matched Sample

\begin{tabular}{|c|c|c|c|c|c|c|c|c|c|c|}
\hline \multicolumn{11}{|c|}{ Panel A - Forecasting and Non-Forecasting Firms at the Earnings Announcement } \\
\hline & \multicolumn{4}{|c|}{ Forecasters } & \multicolumn{4}{|c|}{ Non-Forecasters } & \multicolumn{2}{|c|}{ Test of Mean } \\
\hline & $\mathbf{N}$ & Mean & Median & SD & $\mathbf{N}$ & Mean & Median & SD & tval & pval \\
\hline SML_NB3 (\$7K) & 6,466 & 0.0254 & 0.0056 & 0.447 & 6,466 & 0.0009 & 0.0051 & 0.662 & 2.47 & 0.014 \\
\hline $\mathrm{SML}^{-} \mathrm{NB} 3(\$ 10 \mathrm{~K})$ & 6,466 & 0.0311 & 0.0097 & 0.561 & 6,466 & 0.0035 & 0.0106 & 0.830 & 2.21 & 0.027 \\
\hline LRG_NB3 (\$50K) & 6,466 & -0.0011 & 0.0069 & 1.694 & 6,466 & -0.0334 & 0 & 1.725 & 1.08 & 0.282 \\
\hline LRG_NB3 $(\$ 100 \mathrm{~K})$ & 6,466 & -0.0194 & 0 & 1.571 & 6,466 & -0.0420 & 0 & 1.576 & 0.82 & 0.414 \\
\hline FER & 6,466 & -0.0103 & 0.0006 & 0.276 & 6,466 & 0.0087 & 0.0009 & 0.679 & -2.09 & 0.037 \\
\hline FEA & 6,466 & -0.0035 & 0.0004 & 0.063 & 6,466 & -0.0026 & 0.0009 & 0.051 & -0.93 & 0.350 \\
\hline CAR & 6,466 & 0.0015 & 0.0011 & 0.097 & 6,466 & 0.0004 & 0.0005 & 0.094 & 0.71 & 0.481 \\
\hline LOSS & 6,466 & 0.272 & 0 & 0.445 & 6,466 & 0.264 & 0 & 0.441 & 1.11 & 0.266 \\
\hline ROA & 6,466 & 0.0019 & 0.0094 & 0.057 & 6,466 & 0.0010 & 0.0083 & 0.054 & 0.90 & 0.368 \\
\hline SIZELN & 6,466 & 6.679 & 6.428 & 1.739 & 6,466 & 6.617 & 6.369 & 1.958 & 1.90 & 0.057 \\
\hline SIZE & 6,466 & 13.50 & 13.37 & 1.559 & 6,466 & 13.30 & 13.15 & 1.657 & -1.56 & 0.119 \\
\hline INST & 6,466 & 0.521 & 0.582 & 0.307 & 6,466 & 0.529 & 0.575 & 0.290 & 7.05 & 0.000 \\
\hline MTB & 6,466 & 2,487 & 1,917 & 7,182 & 6,466 & 2,643 & 1,806 & 20,724 & -0.57 & 0.570 \\
\hline STDEV & 6,466 & 0.0243 & 0.0100 & 0.041 & 6,466 & 0.0241 & 0.0100 & 0.038 & 0.21 & 0.830 \\
\hline NUN & 6,466 & 7.246 & 6 & 4.739 & 6,466 & 6.497 & 5 & 5.825 & 8.02 & 0.000 \\
\hline RANG & 6,466 & 0.101 & 0.0909 & 1.546 & 6,466 & 0.0895 & .0909 & 2.328 & 0.33 & 0.742 \\
\hline HTECH & 6,466 & 0.309 & 0 & 0.462 & 6,466 & 0.305 & 0 & 0.460 & 0.61 & 0.542 \\
\hline RETVOL & 6,466 & 0.0324 & 0.0288 & 0.016 & 6,466 & 0.0317 & 0.0282 & 0.017 & 2.64 & 0.008 \\
\hline WEAK & 6,466 & 0.0370 & 0 & 0.189 & 6,466 & 0.0370 & 0 & 0.189 & 0.00 & 1.000 \\
\hline ACQ & 6,466 & 0.0605 & 0 & 0.238 & 6,466 & 0.0650 & 0 & 0.246 & -1.05 & 0.293 \\
\hline LEV & 6,466 & 0.202 & 0.166 & 0.206 & 6,466 & 0.199 & 0.144 & 0.222 & 0.80 & 0.422 \\
\hline AUD & 6,466 & 0.627 & 1 & 0.484 & 6,466 & 0.638 & 1 & 0.481 & -1.31 & 0.189 \\
\hline \multicolumn{11}{|c|}{ Panel B - Forecasters at the Management Forecast and Earnings Announcement } \\
\hline & \multicolumn{4}{|c|}{ Management Forecast } & \multicolumn{4}{|c|}{ Earnings Announcement } & \multirow{2}{*}{\multicolumn{2}{|c|}{$\begin{array}{l}\text { Test of Mean } \\
\text { tval pval }\end{array}$}} \\
\hline & $\mathbf{N}$ & Mean & Median & SD & $\mathbf{N}$ & Mean & Median & SD & & \\
\hline SM & 6,466 & 0.0233 & 0.0066 & 0.4 & 6,466 & 0.0254 & 0.0056 & 0.4 & -0.26 & 0.794 \\
\hline $\mathrm{SML}^{-} \mathrm{N}$ & 6,466 & 0.0343 & 0.0116 & 0.566 & 6,466 & 0.0311 & 0.0097 & 0.561 & 0.33 & 0.744 \\
\hline LRG_NB3 (\$50K) & 6,466 & 0.0487 & 0.0099 & 2.233 & 6,466 & -0.0011 & 0.0069 & 1.694 & 1.43 & 0.154 \\
\hline LRG_NB3 $(\$ 100 \mathrm{~K})$ & 6,466 & 0.0352 & 0 & 2.190 & 6,466 & -0.0194 & 0 & 1.571 & 1.63 & 0.103 \\
\hline FER & 6,466 & 0.0076 & 0.0012 & 0.095 & 6,466 & -0.0103 & 0.0006 & 0.276 & 4.94 & 0.000 \\
\hline FEA & 6,466 & -0.0024 & -0.0006 & 0.019 & 6,466 & -0.0035 & 0.0005 & 0.063 & 1.39 & 0.165 \\
\hline CAR & 6,466 & -0.0068 & -0.0029 & 0.105 & 6,466 & 0.0015 & 0.0011 & 0.097 & -4.71 & 0.000 \\
\hline CAR & 6,466 & -0.0068 & -0.0029 & 0.105 & 6,466 & 0.0015 & 0.0011 & 0.097 & -4.71 & 0.000 \\
\hline
\end{tabular}


The Profitability Effect of Small and Large Investors' Differential Trading around Management Forecasts

Table 4.2 - Descriptive Statistics of Matched Sample (contd)

\begin{tabular}{|c|c|c|c|c|c|c|}
\hline \multicolumn{7}{|c|}{ Panel C - Number of Observations per Fiscal Year } \\
\hline \multirow[t]{2}{*}{ Fiscal year } & \multicolumn{2}{|c|}{ Non-Forecasting } & \multicolumn{2}{|c|}{ Forecasting } & \multicolumn{2}{|c|}{ Full sample } \\
\hline & $\mathrm{N}$ & $\%$ & $\mathrm{~N}$ & $\%$ & $\mathrm{~N}$ & $\%$ \\
\hline 2001 & 392 & 6.06 & 383 & 5.92 & 775 & 5.99 \\
\hline 2002 & 454 & 7.02 & 450 & 6.96 & 904 & 6.99 \\
\hline 2003 & 467 & 7.22 & 478 & 7.39 & 945 & 7.31 \\
\hline 2004 & 568 & 8.78 & 595 & 9.20 & 1,163 & 8.99 \\
\hline 2005 & 684 & 10.58 & 667 & 10.32 & 1,351 & 10.45 \\
\hline 2006 & 724 & 11.20 & 729 & 11.27 & 1,453 & 11.24 \\
\hline 2007 & 841 & 13.01 & 832 & 12.87 & 1,673 & 12.94 \\
\hline 2008 & 868 & 13.42 & 862 & 13.33 & 1,730 & 13.38 \\
\hline 2009 & 758 & 11.72 & 783 & 12.11 & 1,541 & 11.92 \\
\hline 2010 & 710 & 10.98 & 687 & 10.62 & 1,397 & 10.80 \\
\hline Total & 6,466 & 100 & 6,466 & 100 & 12,932 & 100 \\
\hline \multicolumn{7}{|c|}{ Panel D - Number of Observations per Quarter } \\
\hline \multirow[t]{2}{*}{ Fiscal quarter } & \multicolumn{2}{|c|}{ Non-Forecasting } & \multicolumn{2}{|c|}{ Forecasting } & \multicolumn{2}{|c|}{ Full sample } \\
\hline & $\mathrm{N}$ & $\%$ & $\mathrm{~N}$ & $\%$ & $\mathrm{~N}$ & $\%$ \\
\hline 1 & 1,675 & 25.90 & 1,675 & 25.90 & 3,350 & 25.90 \\
\hline 2 & 1,812 & 28.02 & 1,812 & 28.02 & 3,624 & 28.02 \\
\hline 3 & 1,550 & 23.97 & 1,550 & 23.97 & 3,100 & 23.97 \\
\hline 4 & 1,429 & 22.10 & 1,429 & 22.10 & 2,858 & 22.10 \\
\hline Total & 6,466 & 100 & 6,466 & 100 & 12,932 & 100 \\
\hline
\end{tabular}


Table 4.2 - Descriptive Statistics of Matched Sample (contd)

\begin{tabular}{|c|c|c|c|c|c|c|}
\hline \multirow[t]{2}{*}{ Industry } & \multicolumn{2}{|c|}{ Non-Forecasting } & \multicolumn{2}{|c|}{ Forecasting } & \multicolumn{2}{|c|}{ Full sample } \\
\hline & $\mathrm{N}$ & $\%$ & $\mathrm{~N}$ & $\%$ & $\mathrm{~N}$ & $\%$ \\
\hline Agriculture & 5 & 0.08 & 1 & 0.02 & 6 & 0.05 \\
\hline Food Products & 51 & 0.79 & 68 & 1.05 & 119 & 0.92 \\
\hline Candy \& Soda & 12 & 0.19 & 7 & 0.11 & 19 & 0.15 \\
\hline Beer \& Liquor & 8 & 0.12 & 10 & 0.15 & 18 & 0.14 \\
\hline Tobacco Products & 1 & 0.02 & & & 1 & 0.01 \\
\hline Recreation & 41 & 0.63 & 48 & 0.74 & 89 & 0.69 \\
\hline Entertainment & 100 & 1.55 & 95 & 1.47 & 195 & 1.51 \\
\hline Printing \& Publishing & 23 & 0.36 & 20 & 0.31 & 43 & 0.33 \\
\hline Consumer Products & 65 & 1.01 & 49 & 0.76 & 114 & 0.88 \\
\hline Apparel & 54 & 0.84 & 59 & 0.91 & 113 & 0.87 \\
\hline Healthcare & 58 & 0.90 & 51 & 0.79 & 109 & 0.84 \\
\hline Medical Equipment & 286 & 4.42 & 232 & 3.59 & 518 & 4.01 \\
\hline Pharmaceutical Products & 273 & 4.22 & 286 & 4.42 & 559 & 4.32 \\
\hline Chemicals & 202 & 3.12 & 167 & 2.58 & 369 & 2.85 \\
\hline Rubber \& Plastic Products & 59 & 0.91 & 33 & 0.51 & 92 & 0.71 \\
\hline Textiles & 16 & 0.25 & 18 & 0.28 & 34 & 0.26 \\
\hline Construction Materials & 117 & 1.81 & 121 & 1.87 & 238 & 1.84 \\
\hline Construction & 40 & 0.62 & 31 & 0.48 & 71 & 0.55 \\
\hline Steel Works & 134 & 2.07 & 135 & 2.09 & 269 & 2.08 \\
\hline Fabricated Products & 8 & 0.12 & 6 & 0.09 & 14 & 0.11 \\
\hline Machinery & 257 & 3.97 & 239 & 3.70 & 496 & 3.84 \\
\hline Electrical Equipment & 110 & 1.70 & 99 & 1.53 & 209 & 1.62 \\
\hline Automobiles \& Trucks & 105 & 1.62 & 107 & 1.65 & 212 & 1.64 \\
\hline Aircraft & 26 & 0.40 & 33 & 0.51 & 59 & 0.46 \\
\hline $\begin{array}{l}\text { Shipbuilding, Railroad } \\
\text { Equip. }\end{array}$ & 8 & 0.12 & 11 & 0.17 & 19 & 0.15 \\
\hline Defense & 2 & 0.03 & 2 & 0.03 & 4 & 0.03 \\
\hline Precious Metals & - & & - & & - & \\
\hline $\begin{array}{l}\text { Non-Metallic \& Ind. Metal } \\
\text { Mining }\end{array}$ & 19 & 0.29 & 26 & 0.40 & 45 & 0.35 \\
\hline Coal & 11 & 0.17 & 11 & 0.17 & 22 & 0.17 \\
\hline
\end{tabular}




\begin{tabular}{|c|c|c|c|c|c|c|}
\hline Petroleum \& Natural Gas & 304 & 4.70 & 306 & 4.73 & 610 & 4.72 \\
\hline Utilities & 113 & 1.75 & 124 & 1.92 & 237 & 1.83 \\
\hline Communication & 192 & 2.97 & 229 & 3.54 & 421 & 3.26 \\
\hline Personal Services & 95 & 1.47 & 58 & 0.90 & 153 & 1.18 \\
\hline Business Services & 872 & 13.49 & 854 & 13.21 & 1,726 & 13.35 \\
\hline Computers & 258 & 3.99 & 236 & 3.65 & 494 & 3.82 \\
\hline Electronic Equipment & 636 & 9.84 & 844 & 13.05 & 1,480 & 11.44 \\
\hline $\begin{array}{l}\text { Measuring \& Control } \\
\text { Equipment }\end{array}$ & 135 & 2.09 & 86 & 1.33 & 221 & 1.71 \\
\hline Business Supplies & 103 & 1.59 & 68 & 1.05 & 171 & 1.32 \\
\hline Shipping Containers & 19 & 0.29 & 7 & 0.11 & 26 & 0.20 \\
\hline Transportation & 290 & 4.48 & 301 & 4.66 & 591 & 4.57 \\
\hline Wholesale & 220 & 3.40 & 155 & 2.40 & 375 & 2.90 \\
\hline Retail & 289 & 4.47 & 318 & 4.92 & 607 & 4.69 \\
\hline Restaurants, Hotels, Motels & 95 & 1.47 & 136 & 2.10 & 231 & 1.79 \\
\hline Banking & 323 & 5.00 & 314 & 4.86 & 637 & 4.93 \\
\hline Insurance & 199 & 3.08 & 206 & 3.19 & 405 & 3.13 \\
\hline Real Estate & 16 & 0.25 & 21 & 0.32 & 37 & 0.29 \\
\hline Trading & 157 & 2.43 & 177 & 2.74 & 334 & 2.58 \\
\hline Other & 59 & 0.91 & 61 & 0.94 & 120 & 0.93 \\
\hline Total & 6,466 & 100 & 6,466 & 100 & 12,932 & 100 \\
\hline
\end{tabular}

The correlation tables in Table 4.2 Panels $\mathrm{F}$ to $\mathrm{H}$ show that trading variables of small and large investors, as well as the two forecast errors have a low correlation in all three subsamples. The forecast errors are not correlated with the trading variables in any of the subsamples. There is a significant but low correlation between the cumulative abnormal returns and trading behavior of small investors, suggesting that the small investors are likely to trade in the direction of price change. However, this relation does not exist for large investor trading behavior. 


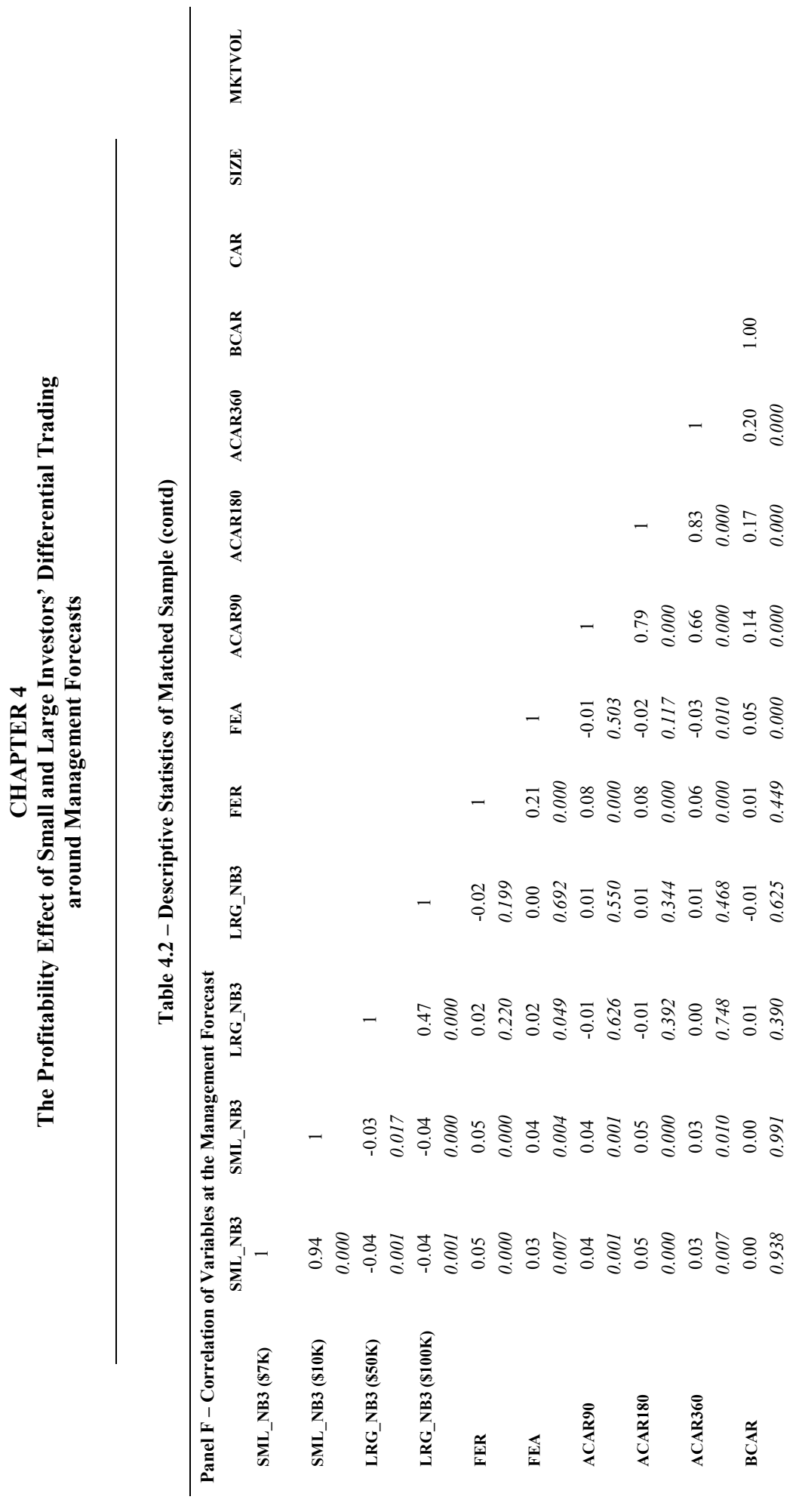

ำ 


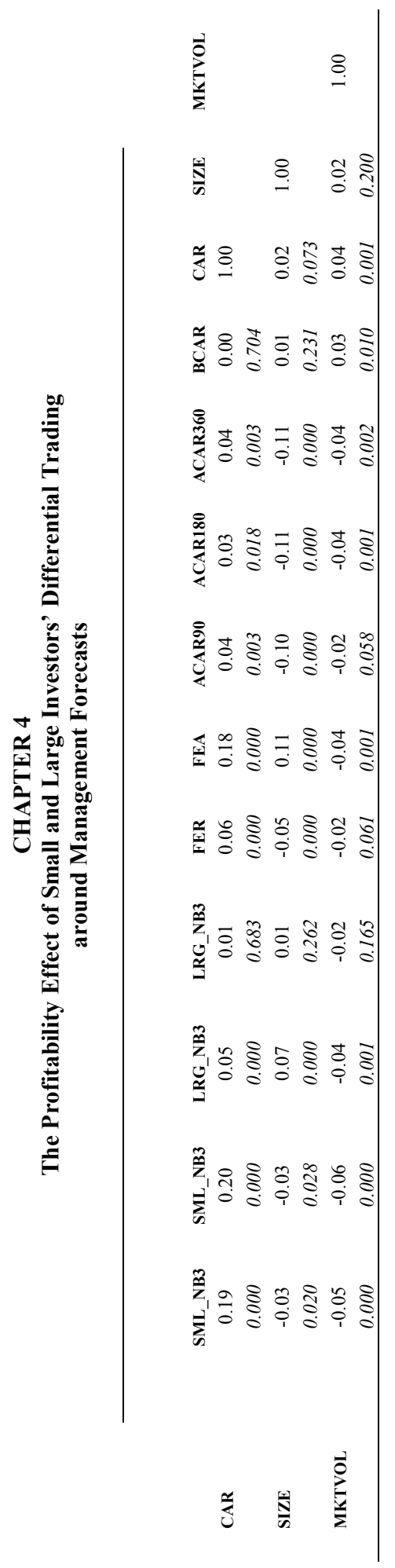




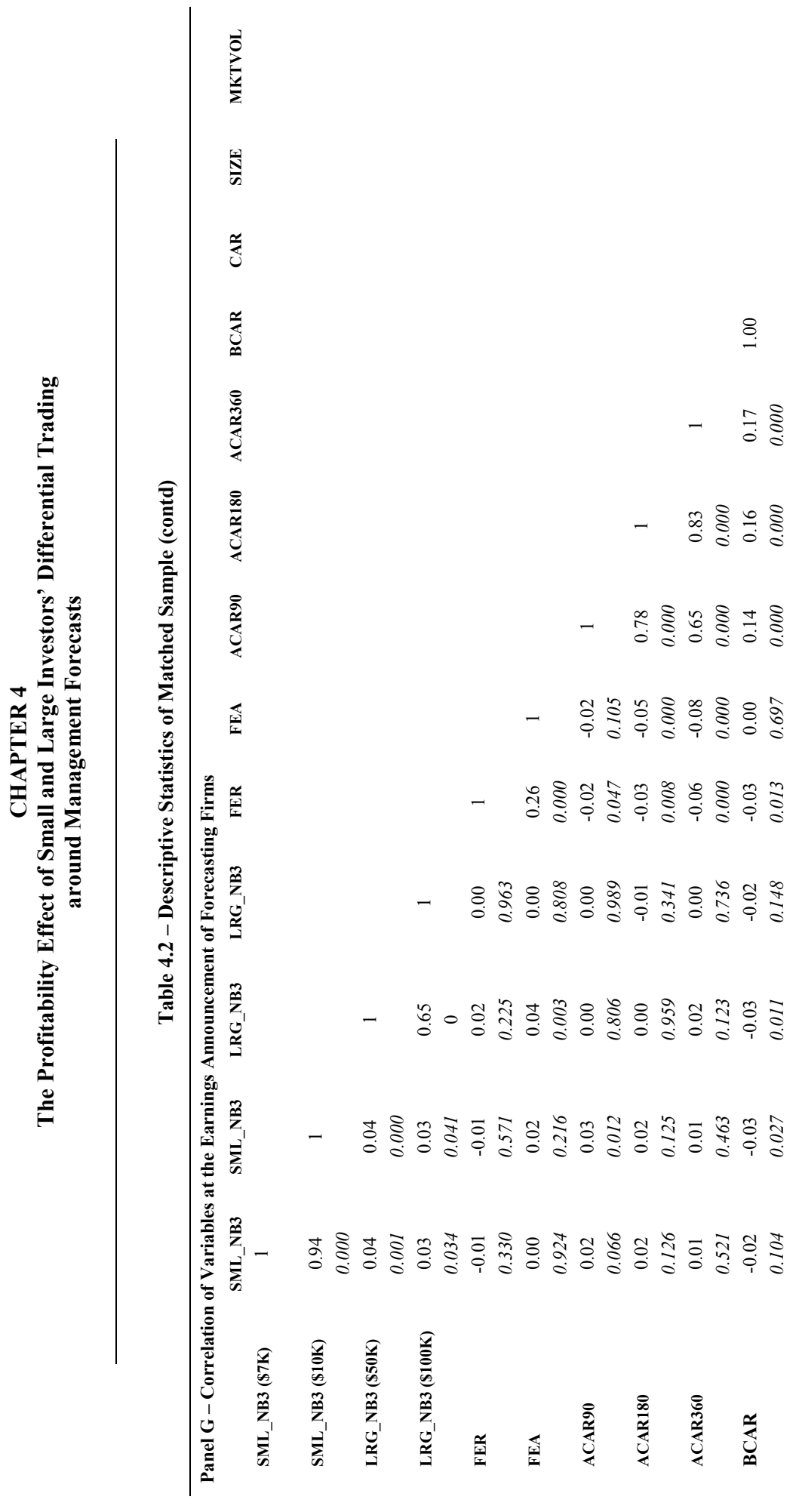




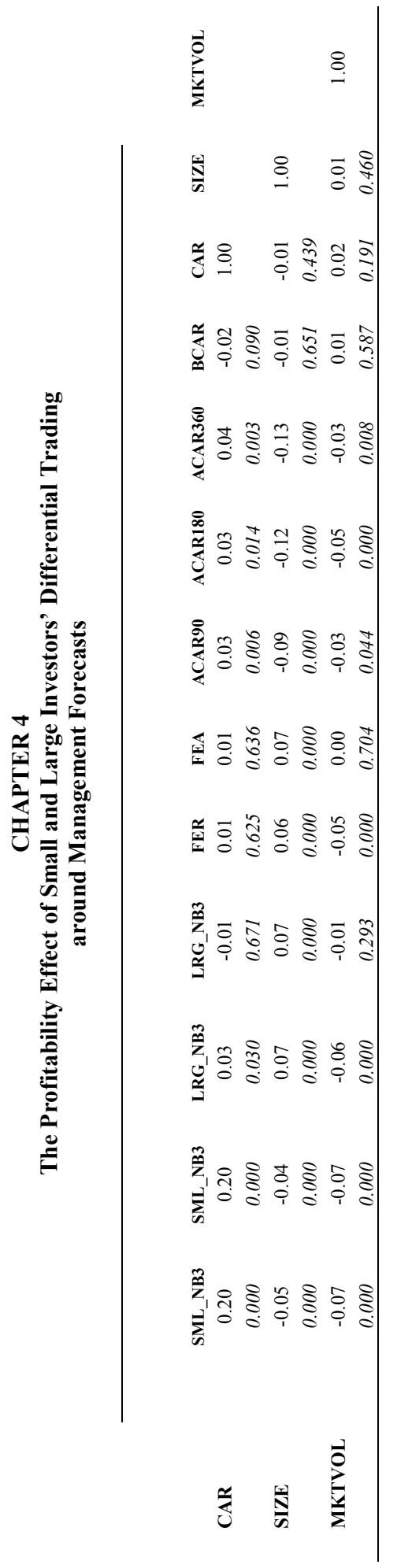




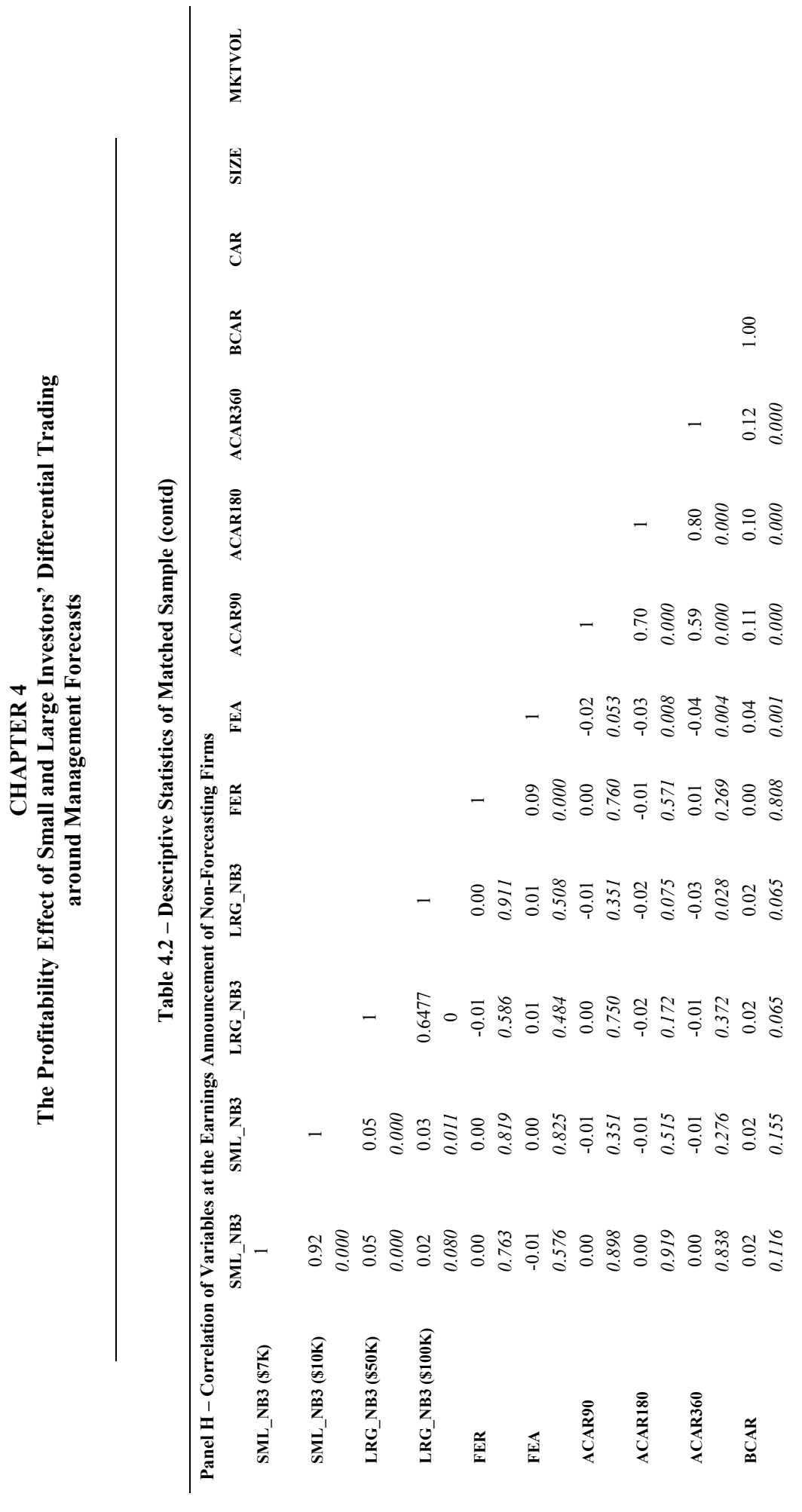

I 


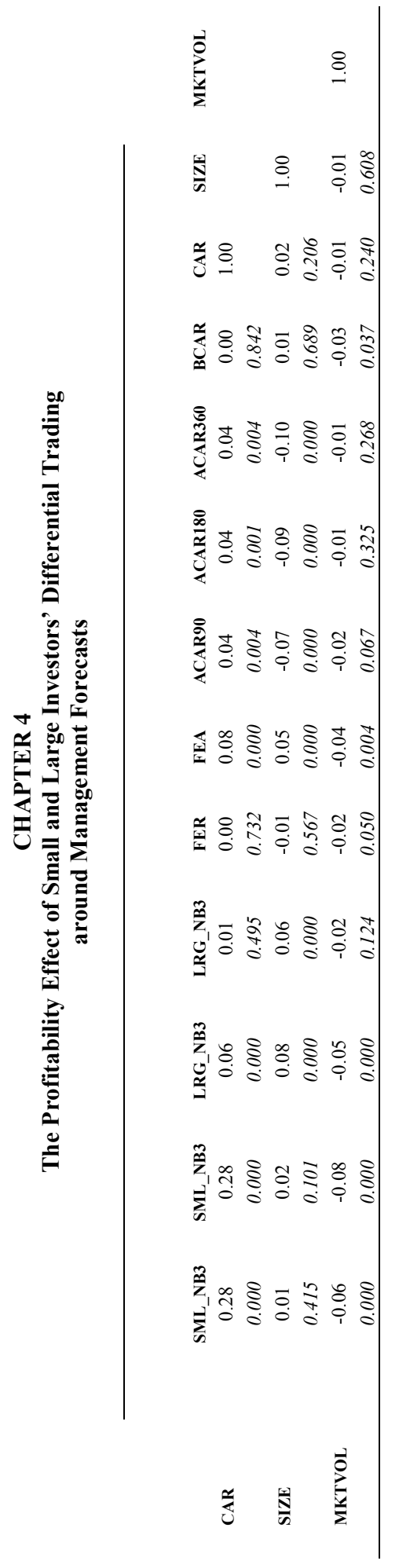


Table 4.3 Panel A shows that bundled management forecasts make up 77\% of the matched sample, which is in line with the findings reported by Rogers and Van Buskirk (2013). Bundled and unbundled management forecasts are different on most matching variables, but are similar on most regression variables. Notable exceptions are the analyst forecastbased forecast error. Unbundled forecast are significantly larger; and cumulative abnormal return, which is more negative for unbundled forecasts. Table 4.3 Panel B shows that $67 \%$ of forecasting firms provide bundled earnings announcements. This is a significantly higher proportion than in Rogers and Van Buskirk (2013). Similarly to management forecasts, bundled and unbundled earnings announcements are also different on most matching variables. Both forecast error variables are larger for unbundled earnings announcements, but there is no significant difference in the cumulative abnormal returns between the bundled and unbundled subsamples. 
CHAPTER 4

The Profitability Effect of Small and Large Investors' Differential Trading around Management Forecasts

Table 4.3 - Descriptive Statistics of Bundling of Forecasting Firms' Forecasts

\& Earnings Announcements

\begin{tabular}{|c|c|c|c|c|c|c|c|c|c|c|}
\hline \multicolumn{11}{|c|}{ Panel A - Management Forecasts } \\
\hline & & Unbt & ndled & & & Bun & dled & & Test 0 & Mean \\
\hline & $\mathbf{N}$ & Mean & Median & SD & $\mathbf{N}$ & Mean & Median & SD & tval & pval \\
\hline SML NB3 (\$7K) & 1,521 & 0.0075 & 0.0081 & 0.505 & 4,945 & 0.0282 & 0.0063 & 0.435 & -1.56 & 0.119 \\
\hline $\mathrm{SML}^{-} \mathrm{NB} 3(\$ 10 \mathrm{k})$ & 1,521 & 0.0145 & 0.0090 & 0.593 & 4,945 & 0.0404 & 0.0124 & 0.557 & -1.56 & 0.119 \\
\hline LRG NB3 (\$50K) & 1,521 & 0.0860 & 0.0118 & 3.924 & 4,945 & 0.0372 & 0.0097 & 1.336 & 0.75 & 0.456 \\
\hline LRG_NB3 (\$100K) & 1,521 & 0.0837 & 0 & 3.900 & 4,945 & 0.0203 & 0 & 1.262 & 0.99 & 0.323 \\
\hline FER & 1,521 & 0.0084 & 0.0030 & 0.147 & 4,945 & 0.0074 & 0.0014 & 0.072 & 0.36 & 0.721 \\
\hline FEA & 1,521 & -0.0032 & -0.0008 & 0.031 & 4,945 & -0.0021 & -0.0005 & 0.012 & -1.93 & 0.054 \\
\hline CAR2 & 1,521 & -0.0242 & -0.0115 & 0.117 & 4,945 & -0.0015 & -0.0003 & 0.010 & -7.43 & 0.000 \\
\hline LOSS & 1,521 & 0.300 & 0 & 0.459 & 4,945 & 0.261 & 0 & 0.439 & 3.03 & 0.002 \\
\hline ROA & 1,521 & -0.0018 & 0.0063 & 0.056 & 4,945 & 0.0033 & 0.0103 & 0.057 & -3.07 & 0.002 \\
\hline SIZELN & 1,521 & 6.982 & 6.718 & 1.900 & 4,945 & 6.588 & 6.307 & 1.676 & 7.75 & 0.000 \\
\hline SIZE & 1,521 & 13.62 & 13.50 & 1.650 & 4,945 & 13.48 & 13.33 & 1.508 & 3.12 & 0.002 \\
\hline INST & 1,521 & 0.519 & 0.573 & 0.294 & 4,945 & 0.523 & 0.585 & 0.310 & -0.46 & 0.647 \\
\hline MTB & 1,521 & 2,318 & 1,864 & 7,212 & 4,945 & 2,568 & 1,941 & 6,154 & -1.32 & 0.185 \\
\hline STDEV & 1,521 & 0.0316 & 0.0200 & 0.041 & 4,945 & 0.0325 & 0.0200 & 0.045 & -0.73 & 0.466 \\
\hline NUMEST & 1,521 & 6.861 & 6 & 4.755 & 4,945 & 6.194 & 5 & 4.171 & 5.27 & 0.000 \\
\hline RANGE & 1,521 & 0.211 & 0.125 & 1.555 & 4,945 & 0.227 & 0.150 & 1.803 & -0.30 & 0.761 \\
\hline HTECH & 1,521 & 0.255 & 0 & 0.436 & 4,945 & 0.326 & 0 & 0.469 & -5.21 & 0.000 \\
\hline RETVOL & 1,521 & 0.0339 & 0.0289 & 0.019 & 4,945 & 0.0317 & 0.0284 & 0.016 & 4.48 & 0.000 \\
\hline WEAK & 1,521 & 0.0217 & 0 & 0.146 & 4,945 & 0.0419 & 0 & 0.200 & -3.64 & 0.000 \\
\hline ACQ & 1,521 & 0.0559 & 0 & 0.230 & 4,945 & 0.0635 & 0 & 0.244 & -1.08 & 0.281 \\
\hline LEV & 1,521 & 0.226 & 0.195 & 0.217 & 4,945 & 0.195 & 0.157 & 0.201 & 5.10 & 0.000 \\
\hline AUD & 1,521 & 0.645 & 1 & 0.479 & 4,945 & 0.622 & 1 & 0.485 & 1.59 & 0.112 \\
\hline
\end{tabular}


CHAPTER 4

The Profitability Effect of Small and Large Investors' Differential Trading around Management Forecasts

Table 4.3 - Descriptive Statistics of Bundling of Forecasting Firms' Forecasts

\& Earnings Announcements (contd)

\begin{tabular}{|c|c|c|c|c|c|c|c|c|c|c|}
\hline \multicolumn{11}{|c|}{ Panel B - Earnings Announcements } \\
\hline & \multicolumn{4}{|c|}{ Unbundled } & \multicolumn{4}{|c|}{ Bundled } & \multicolumn{2}{|c|}{ Test of Mean } \\
\hline & $\mathbf{N}$ & Mean & Median & SD & $\mathbf{N}$ & Mean & Median & SD & & pval \\
\hline SML_NB3 (\$7K) & 2,111 & 0.0231 & 0.0027 & 0.498 & 4,355 & 0.0265 & 0.0069 & 0.420 & -0.29 & 0.776 \\
\hline SML 1 & 2,111 & 0.0267 & 0.0061 & 0.582 & 4,355 & 0.0332 & 0.0116 & 0.550 & -0.44 & 0.661 \\
\hline $\mathrm{LRG}^{-} \mathrm{NB} 3(\$$ & 2,111 & -0.0452 & 0 & 2.153 & 4,355 & 0.0203 & 0.0098 & 1.418 & -1.46 & 0.145 \\
\hline $\mathrm{LRG}^{-} \mathrm{NB} 3(\$ 100 \mathrm{~K})$ & 2,111 & -0.0700 & 0 & 1.949 & 4,355 & 0.0052 & 0 & 1.349 & -1.81 & 0.071 \\
\hline FER & 2,111 & -0.0237 & -0.0011 & 0.438 & 4,355 & -0.0039 & 0.0011 & 0.057 & -2.71 & 0.007 \\
\hline $\mathrm{FE} A$ & 2,111 & -0.0079 & 0.0012 & 0.082 & 355 & -0.0014 & 0.0006 & 0.022 & -3.91 & 0.000 \\
\hline CAR2 & 2,111 & 0.0011 & -0.0004 & 0.092 & 4,355 & 0.0017 & 0.0023 & 0.096 & -0.25 & 0.801 \\
\hline LOs & & & 0 & & & & 0 & 0.051 & 8.53 & 0.000 \\
\hline ROA & 2,111 & -0.0055 & 0.0043 & 0.0 & 355 & 0.0054 & 0.0112 & 1.647 & -7.22 & 0.000 \\
\hline SIZEL & 2,111 & 6.837 & 6.603 & 1.905 & 4,355 & 6.603 & 6.345 & 1.494 & 5.09 & 0.000 \\
\hline SIZE & 2,111 & 13.43 & 13.25 & 1.612 & 4,355 & 13.54 & 13.41 & 0.317 & -2.80 & 0.005 \\
\hline IN & 1 & 0.5 & 0.5 & 0.2 & 5 & 0.522 & 0.591 & 7,148 & -0.43 & 0.667 \\
\hline MT & 2,111 & 2,322 & 1,759 & 7,252 & 4,355 & 2,568 & 1,989 & 0.033 & -1.29 & 0.197 \\
\hline STDEV & 2,111 & 0.0300 & 0.0100 & 0.054 & 4,355 & 0.0215 & 0.0100 & 4.747 & 7.85 & 0.000 \\
\hline NUM & 2,111 & 7.004 & 6 & 4.715 & 4,355 & 7.363 & 6 & 1.484 & -2.85 & 0.004 \\
\hline RAN & 2,111 & 0.0636 & 0.0811 & 1.6 & 4,355 & 0.119 & 0.0952 & 0.470 & -1.35 & 0.176 \\
\hline HTECH & 2,111 & 0.270 & 0 & 0.444 & 4,355 & 0.329 & 0 & 0.015 & -4.79 & 0.000 \\
\hline RETVOL & 2,111 & 0.0342 & 0.0297 & 0.019 & 4,355 & 0.0316 & 0.0283 & 0.192 & 6.10 & 0.000 \\
\hline WEAK & 2,111 & 0.0341 & 0 & 0.182 & 4,355 & 0.0383 & 0 & 0.247 & -0.85 & 0.397 \\
\hline ACQ & 2,111 & 0.0507 & 0 & 0.219 & 4,355 & 0.0652 & 0 & 0.239 & -2.30 & 0.022 \\
\hline LEV & 2,111 & 0.223 & 0.191 & 0.220 & 4,355 & 0.192 & 0.156 & 0.483 & 5.73 & 0.000 \\
\hline AUD & 2,111 & 0.624 & 1 & 0.485 & 4,355 & 0.628 & 1 & & -0.36 & 0.720 \\
\hline
\end{tabular}




\section{CHAPTER 4}

The Profitability Effect of Small and Large Investors' Differential Trading around Management Forecasts

Table 4.4 shows the descriptive statistics of the firm characteristic variables for Hypothesis 3. Forecasting firms are larger, have a higher percentage of recorded intangible assets, a higher stock return volatility, higher analyst following, and they are older. The two types of firms do not differ in terms of the market-to-book ratio and the proportion of high-tech firms.

Table 4.4 - Descriptive Statistics of Firm Characteristics

\begin{tabular}{|c|c|c|c|c|c|c|c|c|}
\hline \multicolumn{9}{|c|}{ Panel A - Forecasting and Non-Forecasting Firms at the Earnings Announcement } \\
\hline & \multicolumn{3}{|c|}{ Forecasters } & \multicolumn{3}{|c|}{ Non-Forecasters } & \multicolumn{2}{|c|}{ Test of Mean } \\
\hline & $\mathbf{N}$ & Mean & SD & $\mathbf{N}$ & Mean & SD & tval & pval \\
\hline INTAN & 6,466 & 0.17 & 0.187 & 6,466 & 0.13 & 0.175 & 13.58 & 0.000 \\
\hline HTECH & 6,466 & 0.31 & 0.462 & 6,466 & 0.30 & 0.460 & 0.61 & 0.542 \\
\hline RETVOL & 6,466 & 0.03 & 0.016 & 6,466 & 0.03 & 0.017 & 2.64 & 0.008 \\
\hline SIZE & 6,466 & 13.50 & 1.559 & 6,466 & 13.30 & 1.657 & 7.05 & 0.000 \\
\hline NUMEST & 6,466 & 7.25 & 4.739 & 6,466 & 6.50 & 5.825 & 8.02 & 0.000 \\
\hline МТB & 6,466 & 2487.47 & 7182.136 & 6,466 & 2642.60 & 20724.020 & -0.57 & 0.570 \\
\hline AGE & 4,243 & 10.12 & 5.931 & 3,798 & 9.50 & 5.973 & 4.67 & 0.000 \\
\hline \multicolumn{9}{|c|}{ Panel B - Forecasters at the Management Forecast and Earnings Announcement } \\
\hline & \multicolumn{3}{|c|}{ Management Forecast } & \multicolumn{3}{|c|}{ Earnings Announcement } & \multicolumn{2}{|c|}{ Test of Mean } \\
\hline & $\mathbf{N}$ & Mean & SD & $\mathbf{N}$ & Mean & SD & tval & pval \\
\hline INTAN & 6,466 & 0.17 & 0.187 & 6,466 & 0.17 & 0.187 & 0.08 & $8 \quad 0.940$ \\
\hline HTECH & 6,466 & 0.31 & 0.462 & 6,466 & 0.31 & 0.462 & -0.06 & $6 \quad 0.954$ \\
\hline RETVOL & 6,466 & 0.03 & 0.017 & 6,466 & 0.03 & 0.016 & -0.87 & 70.386 \\
\hline SIZE & 6,466 & 13.51 & 1.544 & 6,466 & 13.50 & 1.559 & 0.39 & 90.696 \\
\hline NUMEST & 6,466 & 6.35 & 4.324 & 6,466 & 7.25 & 4.739 & -11.21 & 10.000 \\
\hline MTB & 6,466 & 2509.09 & 6418.654 & 6,466 & 2487.47 & 7182.136 & 0.18 & $\begin{array}{ll}8 & 0.857\end{array}$ \\
\hline AGE & 4,240 & 9.90 & 5.952 & 4,243 & 10.12 & 5.931 & -1.69 & 90.090 \\
\hline
\end{tabular}

Panel B shows the difference between the firm characteristics of forecasting firms at the forecast and earnings announcement dates. As expected, the firms do not differ on most variables. However, at the forecast, firms are slightly younger (the forecasts are provided prior to earnings announcements), and have a lower analyst following.

Table 4.4 Panel C and D show the correlation of firm characteristic variables at the earnings announcement date for forecasting and non-forecasting firms. While the variables have a significant, although low correlation in case of forecasting firms, the correlation of the variables for non-forecasting firms, is mostly insignificant. 


\section{CHAPTER 4}

The Profitability Effect of Small and Large Investors' Differential Trading around Management Forecasts

Table 4.4 - Descriptive Statistics of Firm Characteristics (contd)

\begin{tabular}{|c|c|c|c|c|c|c|c|}
\hline & INTAN & НТЕСН & RETVOL & SIZE & NUMEST & МТВ & AGE \\
\hline INTAN & 1 & & & & & & \\
\hline \multirow[t]{2}{*}{ НТЕСН } & 0.03 & 1 & & & & & \\
\hline & 0.018 & & & & & & \\
\hline \multirow[t]{2}{*}{ RETVOL } & -0.09 & 0.23 & 1 & & & & \\
\hline & 0.000 & 0.000 & & & & & \\
\hline \multirow[t]{2}{*}{ SIZE } & 0.04 & -0.25 & -0.48 & 1 & & & \\
\hline & 0.001 & 0.000 & 0.000 & & & & \\
\hline \multirow[t]{2}{*}{ NUMEST } & 0.00 & -0.17 & -0.23 & 0.67 & 1 & & \\
\hline & 0.833 & 0.000 & 0.000 & 0.000 & & & \\
\hline \multirow[t]{2}{*}{ MTB } & -0.04 & 0.05 & -0.05 & 0.09 & 0.04 & 1 & \\
\hline & 0.001 & 0.000 & 0.000 & 0.000 & 0.002 & & \\
\hline \multirow[t]{2}{*}{ AGE } & 0.04 & -0.11 & -0.23 & 0.38 & 0.29 & -0.04 & 1 \\
\hline & 0.016 & 0.000 & 0.000 & 0.000 & 0.000 & 0.010 & \\
\hline
\end{tabular}


The Profitability Effect of Small and Large Investors' Differential Trading around Management Forecasts

Table 4.4 - Descriptive Statistics of Firm Characteristics (contd)

\begin{tabular}{|c|c|c|c|c|c|c|c|}
\hline \multicolumn{8}{|c|}{ Panel D - Correlation of Variables at the Earnings Announcement of Non-Forecasting Firms } \\
\hline & INTAN & НTECH & RETVOL & SIZE & NUMEST & MTB & AGE \\
\hline INTAN & 1 & & & & & & \\
\hline \multirow[t]{2}{*}{ НТЕСН } & 0.04 & 1 & & & & & \\
\hline & 0.002 & & & & & & \\
\hline \multirow[t]{2}{*}{ RETVOL } & 0.01 & 0.22 & 1 & & & & \\
\hline & 0.558 & 0.000 & & & & & \\
\hline \multirow[t]{2}{*}{ SIZE } & 0.01 & -0.23 & -0.40 & 1 & & & \\
\hline & 0.278 & 0.000 & 0.000 & & & & \\
\hline \multirow[t]{2}{*}{ NUMEST } & 0.01 & -0.11 & -0.16 & 0.70 & 1 & & \\
\hline & 0.356 & 0.000 & 0.000 & 0.000 & & & \\
\hline \multirow[t]{2}{*}{ MTB } & 0.00 & 0.02 & -0.01 & 0.03 & 0.02 & 1 & \\
\hline & 0.945 & 0.077 & 0.677 & 0.026 & 0.058 & & \\
\hline \multirow[t]{2}{*}{ AGE } & -0.02 & -0.03 & -0.15 & 0.12 & 0.00 & 0.01 & 1 \\
\hline & 0.273 & 0.050 & 0.000 & 0.000 & 0.883 & 0.482 & \\
\hline
\end{tabular}

The descriptive statistics of forecasting firms by forecast type is shown in Table 4.5. The majority of the sample firms (84\%) issue range forecasts, while point forecasts, the most specific forecast type, are issued by less than $5 \%$ of the sample firms. Accordingly, the mean (1.076) and median (1) of the forecast specificity variable indicate that the sample on average is characterized by range forecasts. The mean difference between the issuance of the management forecast is two months (61 days) in the matched sample. 


\section{CHAPTER 4}

The Profitability Effect of Small and Large Investors' Differential Trading around Management Forecasts

Table 4.5 - Distribution of Sample by Forecast Type \& Descriptive Statistics

\begin{tabular}{lcclcccc}
\hline \multicolumn{7}{l}{ Panel A - Forecast specificity } & \multicolumn{4}{l}{ Panel B - Descriptive Statistics } \\
& $\mathrm{N}$ & $\%$ & & $\mathrm{~N}$ & Mean & Median & SD \\
Point & 286 & 4.42 & SPEC & 6,466 & 1.076 & 1 & 0.399 \\
Range & 5,401 & 83.53 & HORIZON & 6,466 & 60.521 & 61 & 41.704 \\
Other & 779 & 12.05 & & & & & \\
Total & 6,466 & 100 & & \\
\end{tabular}

\subsubsection{Results of Hypothesis Tests}

\section{Trading Around Management Forecasts}

Hypothesis 1 tests the difference-in-difference of small and large investors' trading behavior at the management forecast and the earnings announcement, i.e. whether the difference in the trading behavior of the two groups of investors differs around the two announcements. Results in Table 4.6 Panel A depict that there is a significant difference in the buying, selling and total trading behavior of small investors compared to large investors at the management forecast date. Specifically, the proportion of buy-, sell- and total value of trades by small investors, are significantly higher at the management forecast date than those by large investors. However, neither the percentage of raw netbuys, nor the abnormal net-buy volumes are statistically different between small and large investors around the management forecast. Although the mean net-buy values are higher for large investors, the difference compared to small investors' values is not significant, primarily due to the large standard deviation of large investors' values. These findings imply that the value of shares traded by small investors around the management forecast is higher compared to large investors. However, the two investor groups do not differ significantly in terms of net-buy volumes around management forecasts. 


\section{CHAPTER 4}

\section{The Profitability Effect of Small and Large Investors' Differential Trading around Management Forecasts}

Table 4.6 - Trading Behavior of Small and Large Investors

\begin{tabular}{|c|c|c|c|c|c|c|c|c|c|}
\hline \multicolumn{10}{|c|}{ Panel A - Trading at the Management $F$} \\
\hline \multicolumn{4}{|c|}{ Small Investors } & \multicolumn{4}{|c|}{ Large Investors } & \multicolumn{2}{|c|}{ Test of Mean } \\
\hline & $\mathbf{N}$ & Mean & SD & & $\mathbf{N}$ & Mean & SD & & pval \\
\hline SML_B3 & 458 & 0.55 & 0.274 & LRG_B3 & 458 & .20 & 0.21 & 81.65 & 0.000 \\
\hline SML_S3 & 6,463 & 0.56 & & 53 & 03 & 19 & & 95 & .000 \\
\hline SML_T3 & 6,466 & 0.5 & 0.2 & LRG & 6,466 & 0.20 & 0.20 & 82.56 & 0.000 \\
\hline SML_N3 & 6,466 & 0.0 & 0.3 & $\mathrm{LC}$ & 6,46 & 0.0 & 0.9 & -0.53 & 0.597 \\
\hline SML NB3 & 6,466 & 0.03 & 0.566 & RG NB3 & 6,466 & 0.05 & 2.233 & -0.50 & 0.617 \\
\hline \multicolumn{10}{|c|}{$\begin{array}{l}\text { SML_B3 (LRG_B3) is total value of small (large) buy trades, divided by total value of buy trades in 3-day event } \\
\text { window (-1 to +1) around announcement. SML_S3 (LRG_S3) is total value of small (large) sell trades, divided } \\
\text { by total value of sell trades in 3-day event window }(-1 \text { to }+1 \text { ) around announcement. SML_T3 (LRG_T3) is } \\
\text { total value of small (large) trades (buy + sell trades), divided by total value of trades in 3-day event window (- } \\
1 \text { to }+1 \text { ) around announcement. SML_N3 (LRG_N3) is total value of small (large) raw net-buys (buy less sell } \\
\text { trades), scaled by total raw net-buys in 3-day event window }(-1 \text { to }+1 \text { ) around announcement. SML_NB3 } \\
\text { (LRG_NB3) is abnormal small (large) net-buy volume in 3-day event window (-1 to +1) around announcement. } \\
\text { Small (large) investors' daily abnormal net-buy volume (buy - sell volume) less small (large) investors' mean } \\
\text { daily non-announcement period net-buy volume for firm i, scaled by mean daily non-announcement period total } \\
\text { trading volume for firm i. }\end{array}$} \\
\hline
\end{tabular}

In Table 4.6 Panel B and Panel C we compare the trading behavior of small and large investors around a management forecast to that around an earnings announcement of nonforecasting firms and forecasting firms, respectively. Results indicate that there is a significant difference in the trading behavior of small and large investors around the two announcements. In particular, we find that the proportion of small (large) trades is significantly lower (higher) around management forecasts compared to earnings announcements. However, both the percentage of net-buys and the abnormal net-buy volume of small investors is a higher proportion of trade value around management forecasts than around earnings announcements of non-forecasting firms, while neither of the values of small investors differs when comparing them between management forecasts and their corresponding earnings announcements. Examining large investors, both the percentage of their net-buys and abnormal net-buy volumes are a higher proportion of trade value around management forecasts than around earnings announcements. This implies that both small and large investors, on average, are net buyers, i.e. they buy more than they sell around announcements. Furthermore, small 
investors, on average, trade more in shares of forecasting firms than in those of nonforecasting firms, while large investors trade more around management forecasts than around any earnings announcements.

Table 4.6 - Trading Behavior of Small and Large Investors (contd)

\begin{tabular}{|c|c|c|c|c|c|c|c|c|}
\hline \multicolumn{9}{|c|}{$\begin{array}{l}\text { Panel B - Trading Around the Forecast of Forecasting Firms and Earnings Announcement of Non- } \\
\text { Forecasting Firms }\end{array}$} \\
\hline & \multicolumn{3}{|c|}{ Management Forecast } & \multicolumn{3}{|c|}{$\begin{array}{l}\text { Earnings Announcement } \\
\text { of Non-Forecasting Firm }\end{array}$} & \multicolumn{2}{|c|}{ Test of Mean } \\
\hline & $\mathbf{N}$ & Mean & SD & $\mathbf{N}$ & Mean & SD & tval & pval \\
\hline & & & & & & & - & \\
\hline SML_B3 & 6,458 & 0.55 & 0.27 & 6,446 & 0.58 & 0.27 & 6.00 & 0.000 \\
\hline LRG_B3 & 6,458 & 0.20 & 0.21 & 6,446 & 0.18 & 0.21 & 5.86 & 0.000 \\
\hline & & & & & & & - & \\
\hline SML_S3 & 6,463 & 0.56 & 0.27 & 6,448 & 0.58 & 0.27 & 4.80 & 0.000 \\
\hline LRG_S3 & 6,463 & 0.19 & 0.20 & 6,448 & 0.18 & 0.21 & 4.33 & 0.000 \\
\hline & & & & & & & - & \\
\hline SML_T3 & 6,466 & 0.54 & 0.26 & 6,466 & 0.57 & 0.26 & 5.16 & 0.000 \\
\hline LRG_T3 & 6,466 & 0.20 & 0.20 & 6,466 & 0.19 & 0.21 & 4.93 & 0.000 \\
\hline SML_N3 & 6,466 & 0.02 & 0.40 & 6,466 & 0.00 & 0.41 & 2.33 & 0.020 \\
\hline $\mathrm{LRG}_{-} \mathrm{N} 3$ & 6,466 & 0.03 & 0.90 & 6,466 & -0.01 & 0.88 & 2.33 & 0.020 \\
\hline SML_NB3 & 6,466 & 0.03 & 0.57 & 6,466 & 0.00 & 0.83 & 2.46 & 0.014 \\
\hline LRG_NB3 & 6,466 & 0.05 & 2.23 & 6,466 & -0.03 & 1.72 & 2.34 & 0.019 \\
\hline \multicolumn{9}{|c|}{ Panel C - Trading Around the Management Forecast and Earnings Announcement of Forecasters } \\
\hline & \multicolumn{3}{|c|}{ Management Forecast } & \multicolumn{3}{|c|}{ Earnings Announcement } & \multicolumn{2}{|c|}{ Test of Mean } \\
\hline & $\mathbf{N}$ & Mean & SD & $\mathbf{N}$ & Mean & SD & tval & pval \\
\hline SML_B3 & 6,458 & 0.55 & 0.27 & 6,455 & 0.56 & 0.27 & -2.65 & 0.008 \\
\hline $\mathrm{LRG}_{-} \mathrm{B} 3$ & 6,458 & 0.20 & 0.21 & 6,455 & 0.19 & 0.20 & 1.93 & 0.053 \\
\hline SML_S3 & 6,463 & 0.56 & 0.27 & 6,459 & 0.57 & 0.27 & -2.97 & 0.003 \\
\hline LRG_S3 & 6,463 & 0.19 & 0.20 & 6,459 & 0.18 & 0.20 & 2.48 & 0.013 \\
\hline SML_T3 & 6,466 & 0.54 & 0.26 & 6,466 & 0.56 & 0.26 & -2.92 & 0.003 \\
\hline $\mathrm{LRG}_{-}^{-} \mathrm{T} 3$ & 6,466 & 0.20 & 0.20 & 6,466 & 0.20 & 0.20 & 2.39 & 0.017 \\
\hline SML_N3 & 6,466 & 0.02 & 0.40 & 6,466 & 0.02 & 0.40 & 0.13 & 0.894 \\
\hline LRG_N3 & 6,466 & 0.03 & 0.90 & 6,466 & 0.01 & 1.12 & 0.99 & 0.321 \\
\hline SML_NB3 & 6,466 & 0.03 & 0.57 & 6,466 & 0.03 & 0.56 & 0.33 & 0.744 \\
\hline LRG_NB3 & 6,466 & 0.05 & 2.23 & 6,466 & 0.00 & 1.69 & 1.43 & 0.154 \\
\hline
\end{tabular}


CHAPTER 4

The Profitability Effect of Small and Large Investors' Differential Trading around Management Forecasts

Table 4.6 - Trading Behavior of Small and Large Investors (contd)

\begin{tabular}{|c|c|c|c|c|c|c|c|c|}
\hline \multicolumn{9}{|c|}{ Panel D - Earnings Announcement of Forecasting and Non-Forecasting Firms } \\
\hline & \multicolumn{3}{|c|}{ Management Forecast } & \multicolumn{3}{|c|}{ Earnings Announcement } & \multicolumn{2}{|c|}{ Test of Mean } \\
\hline & $\mathbf{N}$ & Mean & SD & $\mathbf{N}$ & Mean & SD & tval & pval \\
\hline SML B3 & 6,455 & 0.56 & 0.27 & 6,446 & 0.58 & 0.27 & -3.37 & 0.001 \\
\hline LRG_B3 & 6,455 & 0.19 & 0.20 & 6,446 & 0.18 & 0.21 & 4.00 & 0.000 \\
\hline SML_S3 & 6,459 & 0.57 & 0.27 & 6,448 & 0.58 & 0.27 & -1.86 & 0.063 \\
\hline LRG_S3 & 6,459 & 0.18 & 0.20 & 6,448 & 0.18 & 0.21 & 1.92 & 0.055 \\
\hline SML_T3 & 6,466 & 0.56 & 0.26 & 6,466 & 0.57 & 0.26 & -2.25 & 0.025 \\
\hline LRG_T3 & 6,466 & 0.20 & 0.20 & 6,466 & 0.19 & 0.21 & 2.62 & 0.009 \\
\hline SML_N3 & 6,466 & 0.02 & 0.40 & 6,466 & 0.00 & 0.41 & 2.20 & 0.028 \\
\hline LRG_N3 & 6,466 & 0.01 & 1.12 & 6,466 & -0.01 & 0.88 & 1.05 & 0.291 \\
\hline SML_NB3 & 6,466 & 0.03 & 0.56 & 6,466 & 0.00 & 0.83 & 2.21 & 0.027 \\
\hline LRG_NB3 & 6,466 & 0.00 & 1.69 & 6,466 & -0.03 & 1.72 & 1.08 & 0.282 \\
\hline
\end{tabular}

SML_B3 (LRG_B3) is total value of small (large) buy trades, divided by total value of buy trades in 3-day event window (-1 to +1) around announcement. SML_S3 (LRG_S3) is total value of small (large) sell trades, divided by total value of sell trades in 3-day event window $(-1$ to +1$)$ around announcement. SML_T3 (LRG_T3) is total value of small (large) trades (buy + sell trades), divided by total value of trades in 3-day event window (-1 to +1) around announcement. SML_N3 (LRG_N3) is total value of small (large) raw netbuys (buy less sell trades), scaled by total raw net-buys in 3-day event window $(-1$ to +1$)$ around announcement. SML_NB3 (LRG_NB3) is abnormal small (large) net-buy volume in 3-day event window $(-1$ to +1$)$ around announcement. Small (large) investors' daily abnormal net-buy volume (buy - sell volume) less small (large) investors' mean daily non-announcement period net-buy volume for firm i, scaled by mean daily non-announcement period total trading volume for firm $\mathrm{i}$. 


\section{CHAPTER 4 \\ The Profitability Effect of Small and Large Investors' Differential Trading around Management Forecasts}

Table 4.7 shows univariate analyses of the differences in the trading behavior of small and large investors around earnings announcements compared to management forecasts. We find that the difference in the trading behavior of small and large investors (buy-, selland total trade values) is lower at the management forecast than at the earnings announcement date. This result holds for both forecasting and non-forecasting firms.

Table 4.7 - Difference in Trading Behavior of Small and Large Investors

\begin{tabular}{|c|c|c|c|c|c|c|c|c|}
\hline \multirow{2}{*}{$\begin{array}{l}\text { Panel A - Forecast of Fore } \\
\text { Percentage Difference in } \\
\end{array}$} & \multirow{2}{*}{\multicolumn{3}{|c|}{$\begin{array}{l}\text { Management Forecast } \\
\text { N Mean SD }\end{array}$}} & \multicolumn{3}{|c|}{$\begin{array}{c}\text { Earnings } \\
\text { Announcement of } \\
\text { Non-Forecasting Firm }\end{array}$} & \multirow{2}{*}{\multicolumn{2}{|c|}{$\begin{array}{l}\text { Test of Mean } \\
\text { tval pval }\end{array}$}} \\
\hline & & & & $\mathbf{N}$ & Mean & SD & & \\
\hline $\begin{array}{l}\text { SML_B3 - LRG_B3 } \\
\text { SML_S3 - LRG_S3 } \\
\text { SML_T3 - LRG_T3 } \\
\text { SML_N3 - LRG_N3 }\end{array}$ & $\begin{array}{l}6,458 \\
6,463 \\
6,466 \\
6,466\end{array}$ & $\begin{array}{r}0.35 \\
0.36 \\
0.34 \\
-0.01\end{array}$ & $\begin{array}{l}0.46 \\
0.46 \\
0.45 \\
1.00\end{array}$ & $\begin{array}{l}6,446 \\
6,448 \\
6,466 \\
6,466\end{array}$ & $\begin{array}{l}0.40 \\
0.40 \\
0.38 \\
0.01\end{array}$ & $\begin{array}{l}0.46 \\
0.46 \\
0.45 \\
0.95\end{array}$ & $\begin{array}{l}-6.21 \\
-4.81 \\
-5.27 \\
-1.16\end{array}$ & $\begin{array}{l}0.000 \\
0.000 \\
0.000 \\
0.248\end{array}$ \\
\hline \multicolumn{9}{|c|}{$\begin{array}{c}\text { Panel B - Management Forecast and Earnings Announcement of Forecasters } \\
\text { Earnings }\end{array}$} \\
\hline Percentage Difference in & $\mathbf{N}$ & Mean & SD & $\mathbf{N}$ & Mean & SD & & pval \\
\hline $\begin{array}{l}\text { SML_B3 - LRG_B3 } \\
\text { SML_S3 - LRG_S3 } \\
\text { SML_T3 - LRG_T3 } \\
\text { SML_N3 - LRG_N3 }\end{array}$ & $\begin{array}{l}6,458 \\
6,463 \\
6,466 \\
6,466\end{array}$ & $\begin{array}{r}0.35 \\
0.36 \\
0.34 \\
-0.01\end{array}$ & $\begin{array}{l}0.46 \\
0.46 \\
0.45 \\
1.00\end{array}$ & $\begin{array}{l}6,455 \\
6,459 \\
6,466 \\
6,466\end{array}$ & $\begin{array}{l}0.37 \\
0.39 \\
0.36 \\
0.01\end{array}$ & $\begin{array}{l}0.46 \\
0.45 \\
0.44 \\
1.18\end{array}$ & $\begin{array}{l}-2.44 \\
-2.88 \\
-2.80 \\
-0.87\end{array}$ & $\begin{array}{l}0.015 \\
0.004 \\
0.005 \\
0.383\end{array}$ \\
\hline \multicolumn{9}{|c|}{$\begin{array}{r}\text { Panel C - Earnings Announcement of Forecasting and Non-Forecasting Firms } \\
\text { Non-Forecasting }\end{array}$} \\
\hline Percentage Difference in & $\mathbf{N}$ & Mean & SD & $\mathbf{N}$ & Mean & SD & tval & pval \\
\hline $\begin{array}{l}\text { SML_B3 - LRG_B3 } \\
\text { SML_S3 - LRG_S3 } \\
\text { SML_T3 - LRG_T3 } \\
\text { SML_N3 - LRG_N3 }\end{array}$ & $\begin{array}{l}6,455 \\
6,459 \\
6,466 \\
6,466\end{array}$ & $\begin{array}{l}0.37 \\
0.39 \\
0.36 \\
0.01\end{array}$ & $\begin{array}{l}0.46 \\
0.45 \\
0.44 \\
1.18\end{array}$ & $\begin{array}{l}6,446 \\
6,448 \\
6,466 \\
6,466\end{array}$ & $\begin{array}{l}0.40 \\
0.40 \\
0.38 \\
0.01\end{array}$ & $\begin{array}{l}0.46 \\
0.46 \\
0.45 \\
0.95\end{array}$ & $\begin{array}{l}-3.81 \\
-1.98 \\
-2.51 \\
-0.16\end{array}$ & $\begin{array}{l}0.000 \\
0.048 \\
0.012 \\
0.871\end{array}$ \\
\hline
\end{tabular}

SML_B3 - LRG_B3 is the difference in total value of small and large buy trades, divided by the total value of buy trades in the 3-day event window (-1 to +1) around an announcement. SML_S3 - LRG_S3 is the difference in total value of small and large sell trades, divided by the total value of sell trades in the 3-day event window $(-1$ to +1$)$ around an announcement. SML_T3 - LRG_T3 is the difference in total value of small and large trades (buy plus sell trades), divided by the total value of trades in the 3-day event window $(-1$ to +1$)$ around an announcement. SML_N3 - LRG_N3 is the difference in total value of small (large) raw net-buys (buy less sell trades), scaled by the total raw net-buys in the 3-day event window $(-1$ to +1$)$ around an announcement. SML_NB3-LRG_NB3 is the difference in abnormal small (large) net-buy volume in the 3-day event window ( -1 to +1$)$ around an announcement. Small (large) investors' daily abnormal net-buy volume (buy minus sell volume) less small (large) investors' mean daily non-announcement period net-buy volume for firm i, scaled by the mean daily non-announcement period total trading volume for firm i. 


\section{CHAPTER 4 \\ The Profitability Effect of Small and Large Investors' Differential Trading around Management Forecasts}

Taken together our findings mean that the difference in trading between small and large investors is smaller at the management forecast than at the earnings announcement, because small investors trade proportionately less and large investors trade proportionately more around management forecasts compared to their trading around earnings announcements. However, the difference in the net-buy trade percentage of the two classes of investors is statistically not different around the two types of announcements. This means that when buy and sell transactions are netted off, the proportional differences in terms of buy and sell trades of small and large investors balance each other out. While our findings on the net effect of buying and selling behavior of small and large investors around the two announcements are not different, the proportions of buy-, sell-, and total trades of small and large investors' trading do differ between management forecasts and earnings announcements. Hence we conclude that our results support Hypothesis 1.

We provide the results of testing how forecast errors affect small and large investors' abnormal net-buy volume in Table $4.8 .{ }^{30}$ Examining small investors' trades (Columns 1 to 3 , cutoff $\$ 10,000),{ }^{31}$ we document that the random walk forecast error, FER, is positively and significantly associated with small investors' net-buy volume in the forecast regression. This result implies that small investors trade around the management forecast date and their trading behavior around the management forecast is based on random walk expectations. Furthermore, because both the mean and median values of FER are positive at the management forecast, small investors trade in the direction of the forecast error: they buy (sell) more than they sell (buy) when the forecast error is positive (negative).$^{32} \mathrm{We}$ also document that the analyst forecast-based forecast

\footnotetext{
${ }^{30}$ We have tested the multicollinearity of our main variables of interest in all regressions in Table 4.9. Including both forecast errors and all cumulative abnormal returns separately and then simultaneously in the regressions, we find that there is no multicollinearity problem when including all variables in the regressions, and all variables are incrementally significant in explaining both small and large investors' abnormal net-buy volume.

${ }^{31}$ Our results are robust to using alternative cutoffs of $\$ 5,000$ and $\$ 7,000$ to define the abnormal net-buy volume of small investors.

32 The random walk forecast error is positive (negative) when the management forecast announcement is more positive/less negative (more negative/less positive) than the random walk expectation.
} 
error, FEA, is negatively and significantly associated with small investors' net-buy volume in the non-forecasting firm regression. Because both the mean and median values of FEA are negative at the earnings announcement of non-forecasting firms, the negative coefficient of the variable implies that small investors trade in the direction of the analyst forecast- based forecast error at the earnings announcement of non-forecasting firms. This means that our results do not support the findings of Bhattacharya et al. (2007), who documents that small investors trade in the direction of the random walk forecast error around earnings announcements.

The coefficient for FER in small investors' forecasting regression is significantly higher than that in the earnings announcement regression of either forecasting firms or non-forecasting firms. On the other hand, the significantly negative coefficient on FEA in the regression at non-forecasters' earnings announcement is statistically not different from the coefficients in forecasting firms' regressions. This implies that while small investors do not react differently at different announcements to analyst forecast-based forecast errors, the positive random walk forecast error at the management forecast induces significantly more buy trades among small investors compared to earnings announcements. Overall these results imply that, motivated by the optimistic random walk forecast error, small investors trade differentially at the management forecast. 


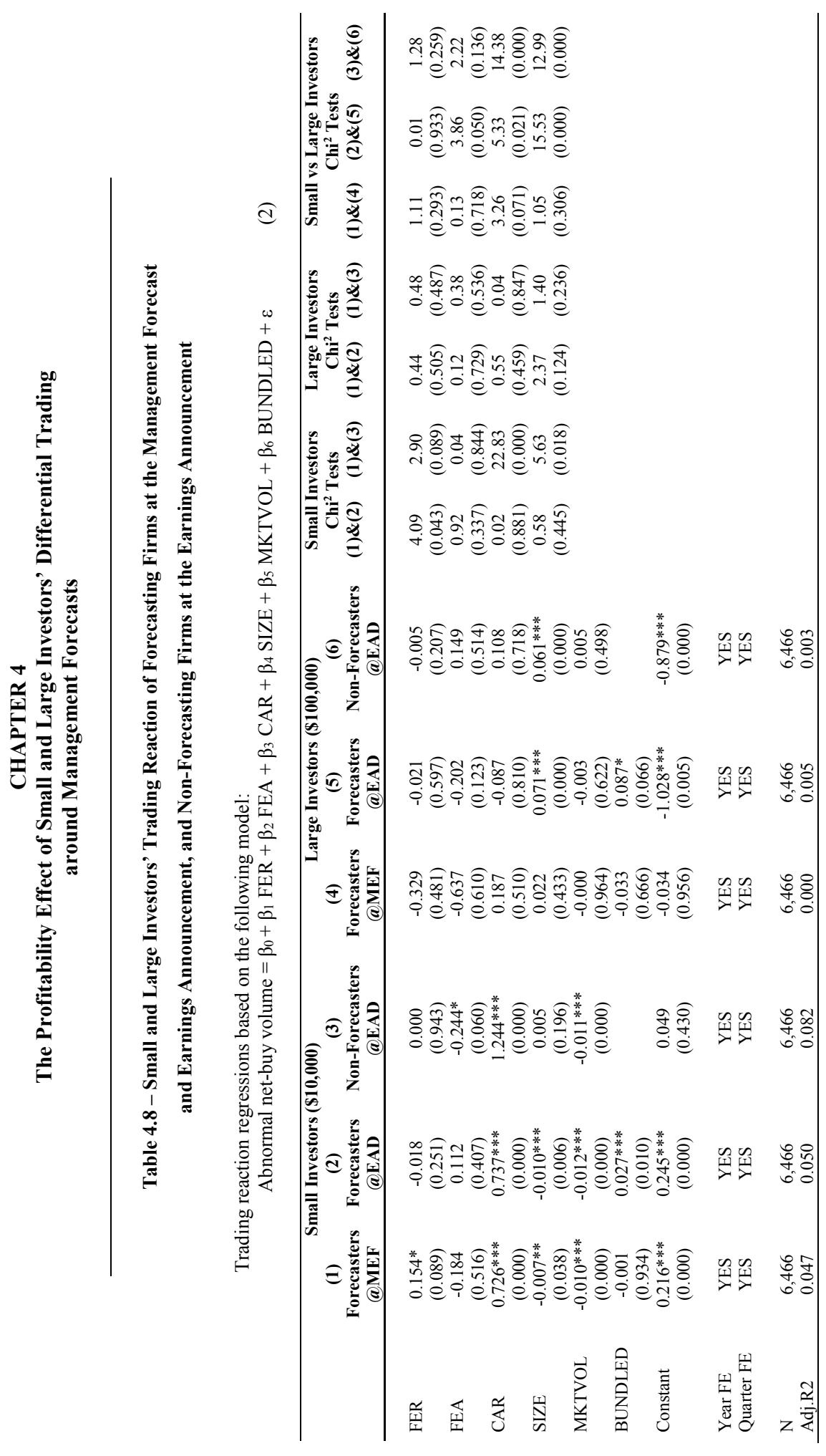




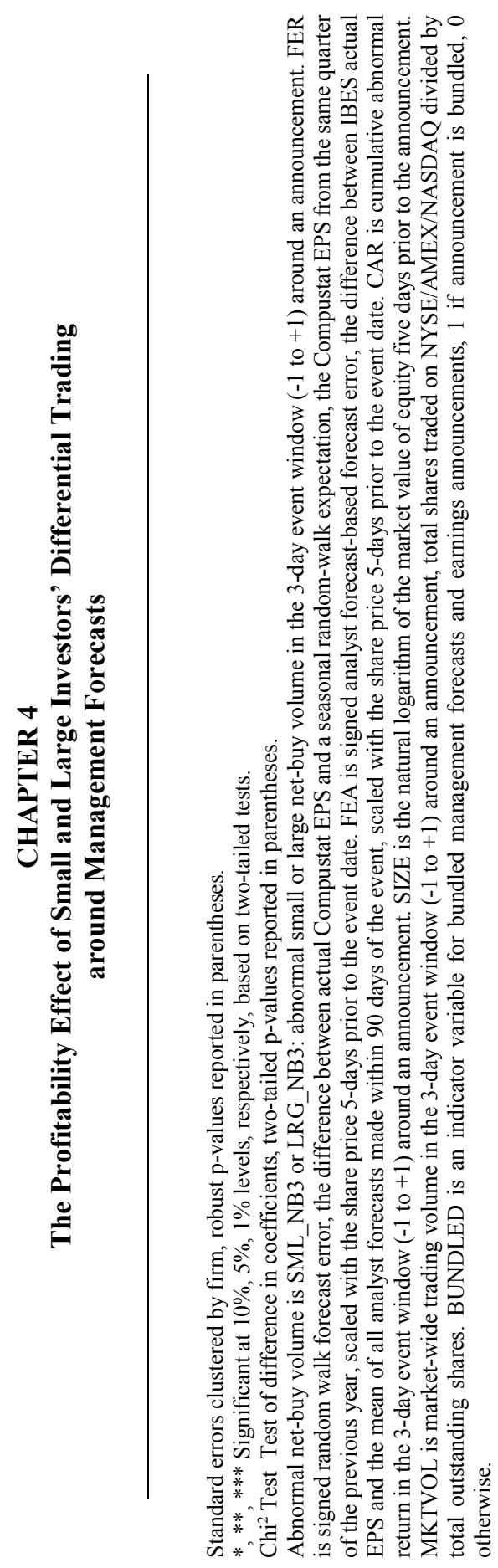




\section{CHAPTER 4 \\ The Profitability Effect of Small and Large Investors' Differential Trading around Management Forecasts}

Table 4.8 Columns 4 to 6 show the effects of forecast errors on large investors' abnormal net-buy volume (cutoff $\$ 100,000) .{ }^{33}$ Neither forecast errors have a significant coefficient in any of the three regressions, nor are the coefficients statistically different in the three regressions around the three announcements. These results could imply that large investors do not trade around the announcements examined, which would be in line with prior findings that large investors in general avoid information-induced trading (Bhattacharya et al., 2007). Alternatively, if large investors do trade on corporate announcements, they are not influenced by either random walk or analyst forecast-based forecast errors. Furthermore, large investors' trades do not differ between different types of announcements, which would imply more consistent and more rational trading behavior by large investors.

In contrast with the trading behavior of large traders, we find that the cumulative abnormal return in the event window, CAR, is significantly positively associated with the trading behavior of small investors for both forecasting firms as well as non-forecasting firms around the earnings and forecast announcements. This result implies that small investors trade in the direction of the price change. SIZE is significant and negative at

33 Examining large investors' trading behavior at the $\$ 50,000$ cutoff, our main specification, untabulated results show that FER is positive and weakly significant at the management forecast date, and negative and highly significant at the earnings announcement of non-forecasting firms. These results imply that large investors also trade on the random walk forecast error at the management forecast, and also in the direction of the forecast error. Furthermore, large investors trade on the random walk forecast error at the earnings announcement of non-forecasting firms as well. However, because the mean and median of FER is positive, the negative coefficient on FER implies that large investors trade against the random walk forecast error. The random walk forecast error is significantly higher in the regression at the management forecast than in the two earnings announcement regressions, while the coefficient on the analyst forecast-based forecast error is not different between the three regressions, similarly to small investors' regressions. These results are surprising because they are more similar to small investors' trading behavior than to the expectation of more sophisticated trading by large investors, therefore we have examined an alternative definition of the abnormal net-buy volume of large investors at a larger cutoff of $\$ 100,000$, to test the robustness of the results.

Taking the results of the two specifications of large investors' abnormal net-buy volume together, we conclude, that the cutoff of $\$ 100,000$ yields results more in line with the expectations of sophisticated trading behavior. The specification with the cutoff of $\$ 50,000$ may include some wealthy individuals, whose trading may be less sophisticated. Therefore the appropriate cutoff to identify large traders is likely to be somewhere in the range of $\$ 50,000$ to $\$ 100,000$.

In the rest of the paper we report results of large investors' trading behavior based on the cutoff of $\$ 100,000$. 


\section{CHAPTER 4 \\ The Profitability Effect of Small and Large Investors' Differential Trading around Management Forecasts}

both announcements of forecasting firms for small investors, and it is positive and significant for large investors around the earnings announcements of both forecasting and non-forecasting firms. This implies that small investors prefer to trade in smaller forecasting and larger non-forecasting firms, and larger firms induce more net-buy volume among large investors at earnings announcements. MKTVOL is significant and negative in all of the small investor regressions, but the coefficients are insignificant in all large investor regressions. This suggests that small investors' net-buy volume around announcements is negatively influenced by overall trading levels in the market, which implies that corporate announcements are less prominent for small investors if trading in the market is high. We do not find any evidence of the effect of market volume on large investors' trading behavior. The indicator variable of other announcements being issued at the same time, BUNDLED, is not significant in the forecast regressions, but it is positive and significant in the earnings announcement regressions in both small and large investors' trades. This implies that investors' trading behavior around the management forecast date is not affected by earnings announcements being bundled to it, but both investor groups have a higher net-buy volume, i.e. buy more at the earnings announcement, if those are bundled with forecasts.

Next, we conduct chi-square tests to determine whether there is a significant difference in the effects of independent variables across the six regressions. Comparing small and large investors' trading behavior with regard to the two forecast errors, we find weak results. In the forecasting regressions, the coefficient of FER is significantly positive for small investors, but negative and insignificant for large investors, however their difference is not significant. Similarly, the coefficient of FEA at the earnings announcement of non-forecasting firms for small investors is significantly negative, while it is positive and insignificant for large investors, however their difference is only weakly significant. CAR is significantly higher for small investors in all three regressions than for large investors, implying that small investors' trading behavior influences stock prices more at announcements. SIZE is significantly higher for large investors at the two earnings announcements, implying that large investors prefer larger firms more compared to small investors. 


\section{CHAPTER 4 \\ The Profitability Effect of Small and Large Investors' Differential Trading around Management Forecasts}

Examining whether the difference between small and large investors' trading reactions at the earnings announcement are different from those at the management forecast, we find no difference for FEA $\left(\mathrm{Chi}^{2}=0.44, \mathrm{p}=0.510\right)$ and very weak results for FER $\left(\mathrm{Chi}^{2}=1.08, \mathrm{p}=0.298\right)$. The statistically insignificant results could be the result of the large standard errors of insignificant coefficients, therefore, while we accept that there is no difference between small and large investors' reactions at the earnings announcement (both values are insignificant, i.e. 0), despite the statistical insignificance we argue that there is a difference in small and large investors' reactions at the management forecast (small investors' coefficient is significantly positive, while large investors' is insignificant, i.e. 0). Hence we conclude that these results, despite the weak statistics, support Hypothesis 1: small investors trade in the direction of a random walk forecast error around the management forecast but not around earnings announcements, in contrast with large investors, who do not trade differentially around corporate announcements. In sum, management forecasts influence the trading behavior of small and large investors differentially, while there is a difference in small and large investors' trading behavior at the management forecast, there is not at earnings announcements.

\section{Profitability of Small Investors' Trades}

Hypothesis 2 tests whether the difference in profitability between small and large investors' trades differs around management forecasts and earnings announcements. Table 4.9 shows the results for ACAR in the 90-, 180- and 360-day periods following the event-window. ${ }^{34}$ The coefficient on small investors' net-buy volume is significantly positive in the management forecast regression, significantly negative in the regression at non-forecasting firms' earnings announcement, but it is insignificant in the regression at the earnings announcement of forecasting firms. The coefficient on large investors' netbuy volume is weakly positive in the management forecast regression, insignificant or weakly positive in the regression at the earnings announcement of forecasting firms, and negative, with increasing significance from the 90 - to the 360-day window in the

\footnotetext{
${ }^{34}$ Inferences are unchanged, although results are less significant in shorter ACAR windows of 15-, 30-, and 60-days.
} 


\section{CHAPTER 4 \\ The Profitability Effect of Small and Large Investors' Differential Trading around Management Forecasts}

regression at non-forecasting firms' earnings announcement. The coefficients are not different between forecasting firms' earnings announcements for either small or large investors, but they are significantly higher at the management forecast compared to the earnings announcement of non-forecasting firms both for small and large investors at the two announcements.

These results imply that both small and large investors trade profitably at the management forecast, they do not make gains or losses on their trades at forecasting firms' earnings announcements, and both investor groups make losses on trading at nonforecasting firms' earnings announcements. Comparing small and large investors' trading profitability at the three announcements, small investors trade significantly more profitably at the management forecast, and make significantly more losses on their trades at the earnings announcements of non-forecasting firms compared to large investors. The difference in profitability between small and large investors' trades around management forecasts and earnings announcements of forecasting firms is the same, implying that management forecasts do not cause differential profitability effects for the two groups of investors in their trades of forecasting firms' stocks. However, the difference in profitability between small and large investors' trades is significantly higher around management forecasts than at the earnings announcements of non-forecasting firms: while small investors lose significantly more on trades of non-forecasting firms' announcements, they gain significantly more on trades of management forecasts. These findings support Hypothesis 2.

Examining the finding of small investors' profitability around the management forecast in light of the post earnings-announcement drift literature (e.g., Bernard and Thomas, 1989 and 1990; Bartov et al., 2000; Ke and Ramalingegowda, 2005), we find that our results for management forecasts are similar to that of Hirshleifer et al. (2008) for earnings announcement: it is not small investors who cause the post-earnings announcement drift at the management forecast. ${ }^{35}$ In our sample, contrary to the direction of trading required for drift, small investors buy more of GN and sell more of the BN

${ }^{35}$ In contrast to our sample, Hirshleifer et al. (2008) use a proprietary sample of actual individual investor trades. 


\section{CHAPTER 4}

The Profitability Effect of Small and Large Investors' Differential Trading around Management Forecasts

firms at the management forecast date, where news is defined in relation to the random walk earnings expectation. However, our results are consistent with small investors benefiting from drift following the management forecast, if they hold their investments beyond two months, i.e. beyond the subsequent earnings announcement.

In sum, our results suggests that small investors gain from their trades at the management forecast so much more compared to large investors, because they rely on naïve earnings expectations, which result in positive forecast errors. This positive random walk forecast error, in turn, motivates small investors to buy, and if they hold the shares beyond the earnings announcement, they gain due to a "post-management forecast drift".

Table 4.9 - Profitability of Small and Large Investors' Trading around the Management Forecast and Earnings Announcement of Forecasting Firms and the Earnings Announcement of Non-Forecasting Firms

Profitability regressions based on the following model:

$$
\begin{gathered}
\mathrm{ACAR}=\beta_{0}+\beta_{1} \mathrm{SML} \text { NB3 }+\beta_{2} \text { LRG_NB3 }+\beta_{3} \mathrm{CAR}+\beta_{4} \mathrm{BCAR} \\
+\bar{\beta}_{5} \mathrm{SIZE}+\beta_{6} \mathrm{BUNDLED}+\varepsilon
\end{gathered}
$$

\begin{tabular}{|c|c|c|c|c|c|c|c|c|}
\hline \multicolumn{2}{|c|}{$\begin{array}{c}\text { Panel A - 90-days ACAR } \\
\text { (1) } \\
\text { Forecasters } \\
\text { aMEF } \\
\end{array}$} & F Test & $\begin{array}{c}(2) \\
\text { Forecasters } \\
\text { aEAD }\end{array}$ & F Test & $\begin{array}{c}(3) \\
\text { Non-Forecasters } \\
\text { aEAD }\end{array}$ & F Test & Chi $^{2}$ Tests & $\begin{array}{l}\text { ests } \\
\text { (1)\&(3) }\end{array}$ \\
\hline SML_NB3 & $\left.\begin{array}{l}0.028 * * \\
(0.029)\end{array}\right]$ & 4.26 & $\begin{array}{c}0.020 \\
(0.181)\end{array}$ & 1.44 & $\left.\begin{array}{c}-0.019^{*} \\
(0.093)\end{array}\right]$ & 2.17 & $\begin{array}{c}0.24 \\
(0.623)\end{array}$ & $\begin{array}{c}7.60 \\
(0.006)\end{array}$ \\
\hline LRG_NB3 & $\begin{array}{c}0.002 \\
(0.116)\end{array}$ & $-(0.039)$ & $\begin{array}{c}0.002 \\
(0.453)\end{array}$ & $-(0.231)$ & $\begin{array}{l}-0.002 \\
(0.488)\end{array}$ & $\zeta(0.141)$ & $\begin{array}{c}0.00 \\
(0.957)\end{array}$ & $\begin{array}{c}1.49 \\
(0.222)\end{array}$ \\
\hline CAR & $\begin{array}{l}0.106^{* *} \\
(0.022)\end{array}$ & & $\begin{array}{c}0.101 \\
(0.115)\end{array}$ & & $\begin{array}{c}0.148^{* *} \\
(0.023)\end{array}$ & & & \\
\hline BCAR & $\begin{array}{c}0.385 * * * \\
(0.000)\end{array}$ & & $\begin{array}{c}0.345^{* * *} \\
(0.000)\end{array}$ & & $\begin{array}{c}0.308 * * * \\
(0.000)\end{array}$ & & & \\
\hline SIZE & $\begin{array}{c}-0.023 * * * \\
(0.000)\end{array}$ & & $\begin{array}{c}-0.023 * * * \\
(0.000)\end{array}$ & & $\begin{array}{c}-0.017 * * * \\
(0.000)\end{array}$ & & & \\
\hline BUNDLED & $\begin{array}{c}0.008 \\
(0.419)\end{array}$ & & $\begin{array}{c}0.001 \\
(0.897)\end{array}$ & & & & & \\
\hline Constant & $\begin{array}{c}0.314^{* * * *} \\
(0.000)\end{array}$ & & $\begin{array}{c}0.301 * * * \\
(0.000)\end{array}$ & & $\begin{array}{c}0.190 * * * \\
(0.000)\end{array}$ & & & \\
\hline Year FE & YES & & YES & & YES & & & \\
\hline Quarter FE & YES & & YES & & YES & & & \\
\hline $\mathrm{N}$ & 6,466 & & 6,466 & & 6,465 & & & \\
\hline Adj.R2 & 0.049 & & 0.048 & & 0.028 & & & \\
\hline
\end{tabular}


CHAPTER 4

The Profitability Effect of Small and Large Investors' Differential Trading around Management Forecasts

Table 4.9 - Profitability of Small and Large Investors' Trading

around the Management Forecast and Earnings Announcement of Forecasting Firms

and the Earnings Announcement of Non-Forecasting Firms (contd)

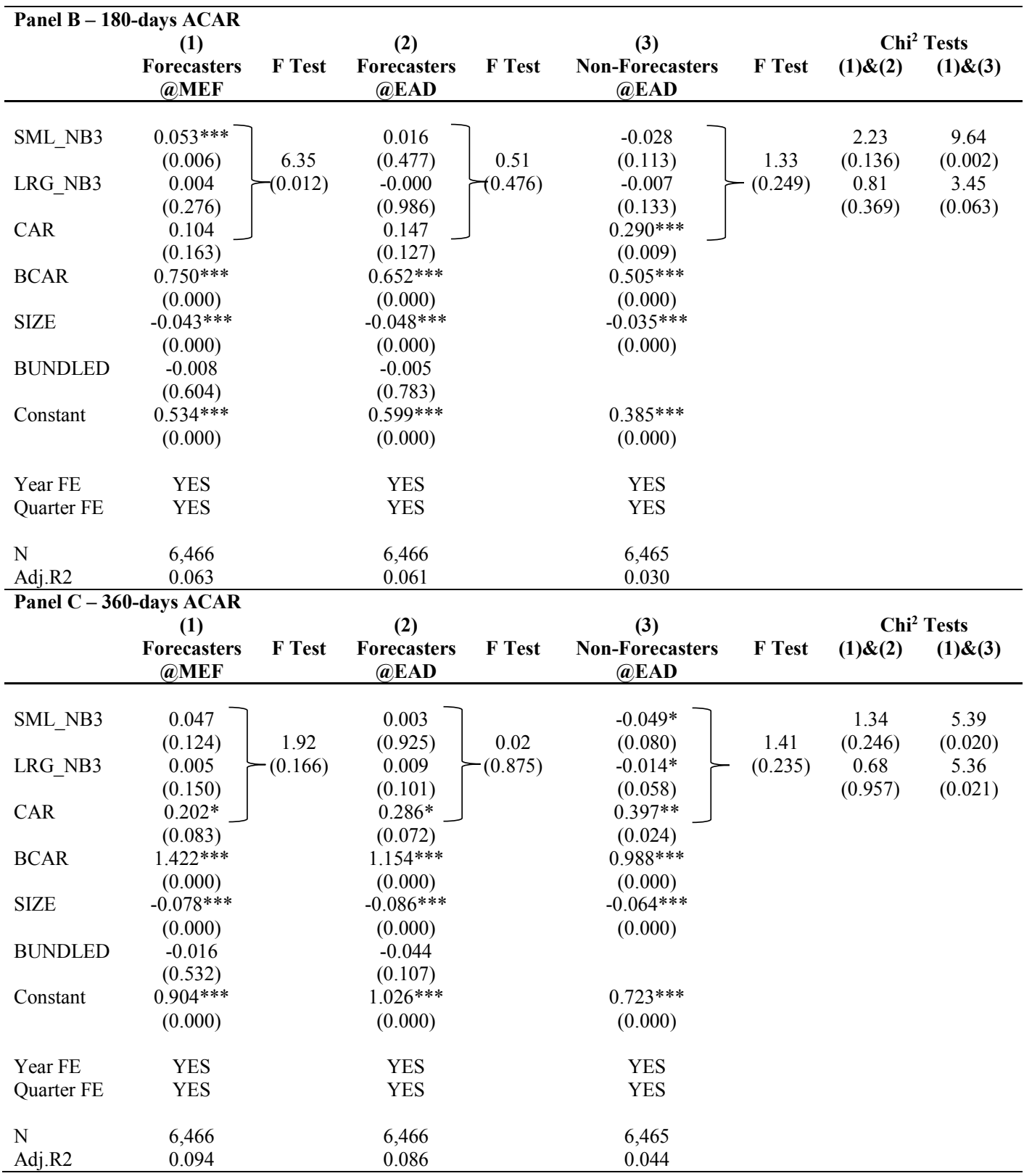




\section{CHAPTER 4 \\ The Profitability Effect of Small and Large Investors' Differential Trading around Management Forecasts}

Standard errors clustered by firm, robust $\mathrm{p}$-values reported in parentheses.

$*, * *, * * *$ Significant at $10 \%, 5 \%, 1 \%$ levels, respectively, based on two-tailed tests.

F Test Test of difference in coefficients $\left(\mathrm{H}_{0}: \beta_{\mathrm{i}}+\beta_{\mathrm{j}}=0\right)$, two-tailed p-values reported in parentheses.

$\mathrm{Chi}^{2}$ Test Test of difference in coefficients, two-tailed p-values reported in parentheses.

ACAR is cumulative abnormal return in the period following the event-window. SML_NB3 (LRG_NB3) is abnormal small (large) net-buy volume in the 3 -day event window $(-1$ to +1$)$ around an announcement. CAR is cumulative abnormal return in the 3 -day event window $(-1$ to +1$)$ around an announcement. BCAR is cumulative abnormal return in the 15 days preceding the event-window. SIZE is the natural logarithm of the market value of equity five days prior to the announcement. BUNDLED is an indicator variable for bundled management forecasts and earnings announcements, 1 if announcement is bundled, 0 otherwise.

\section{Firm Characteristics}

Hypothesis 3a examines the effect of firm complexity on the profitability differential of small and large investors at the management forecast compared to earnings announcements. Table 4.10 Panel A shows the results of testing profitability differences of firm complexity between small and large investors in the 90-, 180- and 360-day periods following the event-window. The coefficients on the interaction terms of INTAN and small and large investors' net-buy volume, respectively, are all insignificant. This implies that the proportion of intangible assets a firm has does not influence the profitability of their trading for either small or large investors at any corporate announcements, and, therefore, also has no effect on the profitability differential of small and large investors.

The coefficient on the interaction term of HTECH with small investors' net-buy volume are negative and insignificant at forecasting firms' announcements, and positive and significant at non-forecasting firms' earnings announcement. The coefficient on the interaction term with large investors' net-buy volume is negative and significant at the earnings announcement of forecasting firms and insignificant at the other two announcements. This implies that small investors' long-term trading profits are higher if they trade in high-tech non-forecasting firms at their earnings announcement, while the profitability of large investors is lower if they trade in high-tech forecasting firms at the earnings announcement. This difference in profitability is only significant at the earnings announcement of non-forecasting firms. While investing in high-tech firms benefits small investors at the earnings announcement in terms of their long term profitability, it does not improve the profitability of any of the two groups of investors over the other at the 
management forecast date. Because the profitability difference between small and large investors' trading at the earnings announcement of non-forecasting firms does not exist at the management forecast, there is a difference between the effect of high-tech firms on small and large investors' profitability difference at the management forecast compared to earnings announcements.

While the sign and significance of the coefficients on the interaction terms of OPVOL and small and large investors' net-buy volume vary between investor groups and period length, the coefficients are all zero. The only significant difference in coefficients is between that of forecasting firms' two announcements for large investors. As a result the difference in small and large investors' profitability is not influenced differentially by firms' volatility of operating performance at the management forecast and earnings announcements.

In sum, firm complexity, as measured by INTAN and OPVOL does not, but as measured by HTECH, does influence the profitability difference, because small investors' profitability advantage at the earnings announcement disappears at the management forecast. These findings partially support $\mathrm{H} 3 \mathrm{a}$.

Hypothesis $3 \mathrm{~b}$ examines if richer information environments of firms influence the profitability differential of small and large investors at the management forecast compared to earnings announcements. Table 4.10 Panel B shows the results of testing of testing the profitability differences of firms' information environments between small and large investors in the 90-, 180- and 360-day periods following the event-window. 


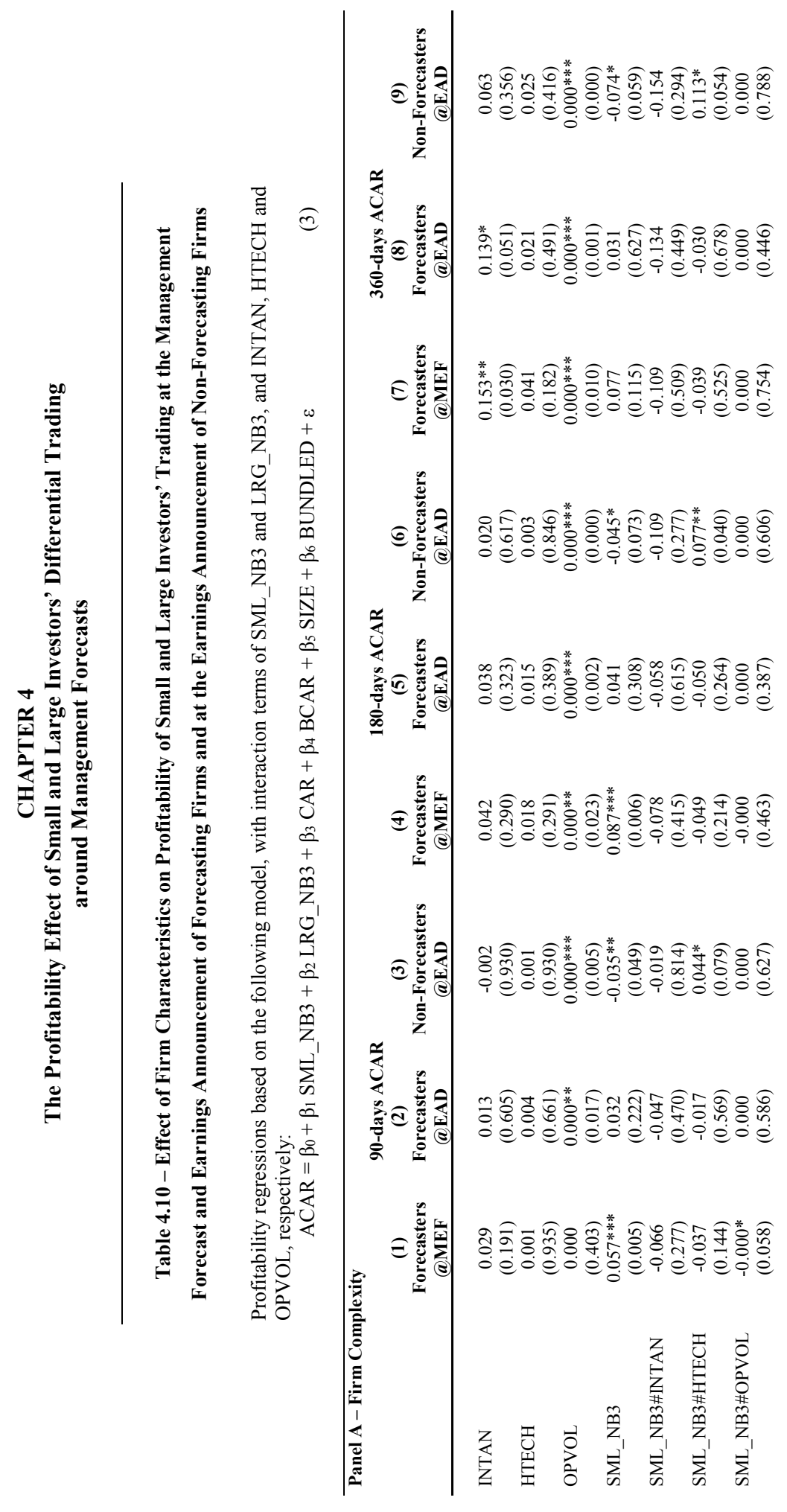




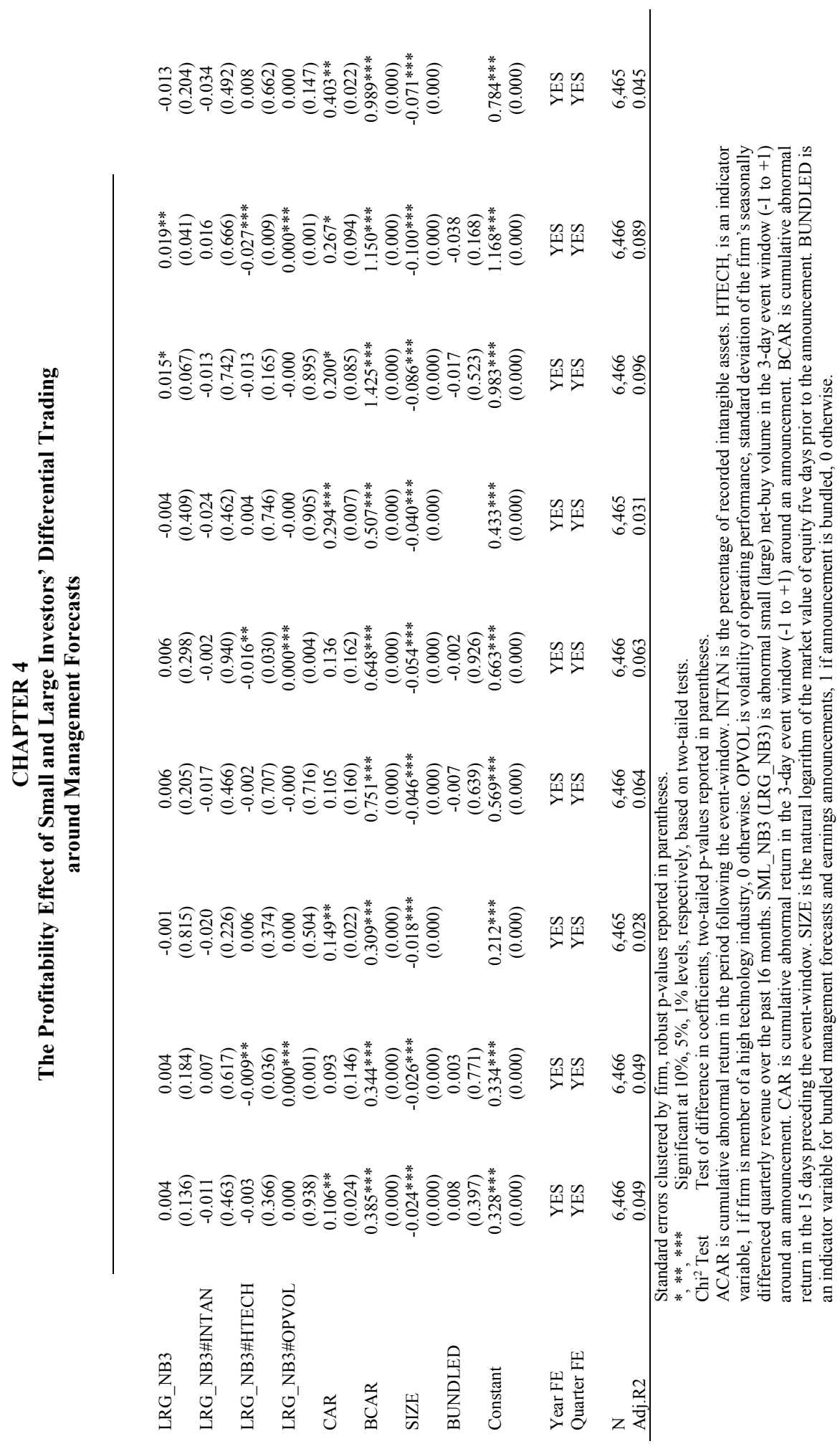




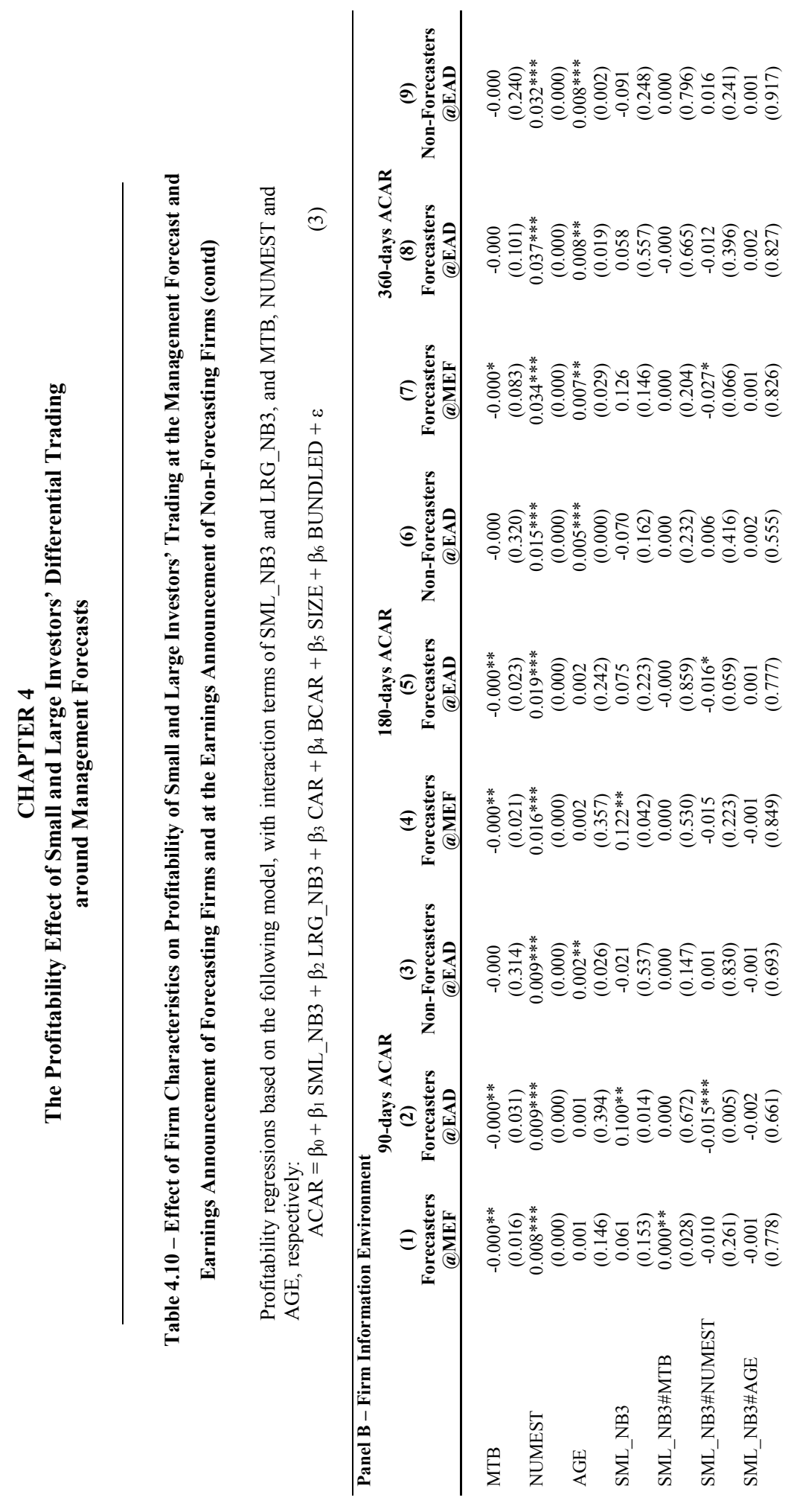




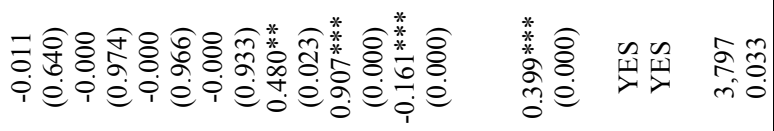

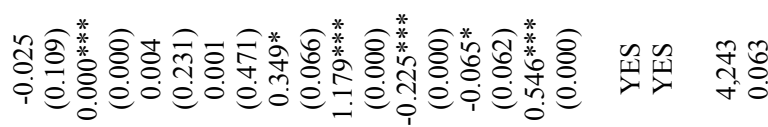

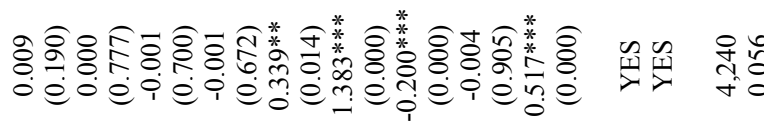

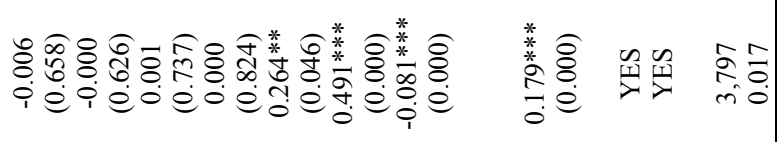

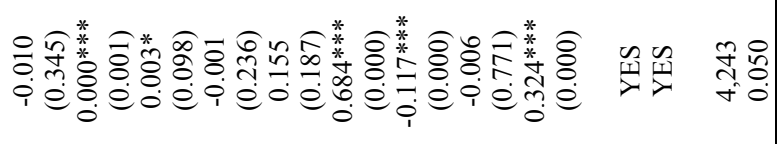

Ð

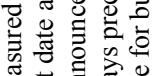

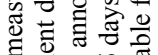

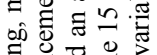

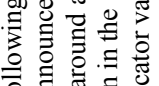

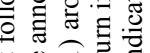

禹桒总.声

뜰

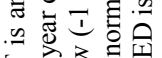

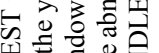

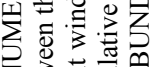

乙苛焉

○文芯

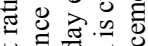

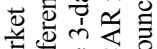

芯导导导

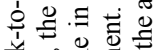

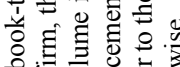

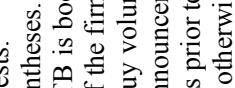

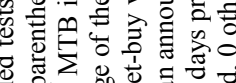
记

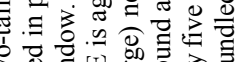

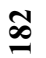

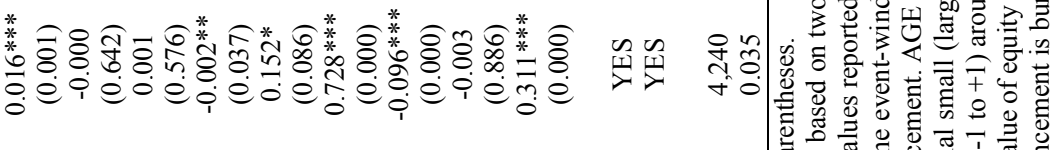

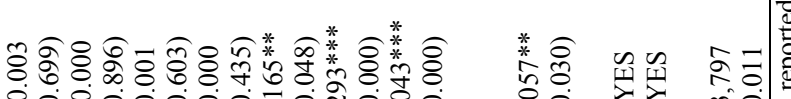

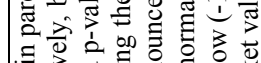

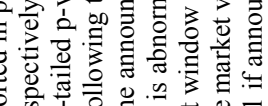

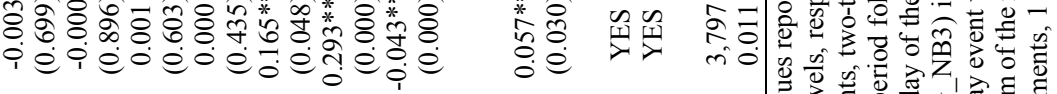

竞

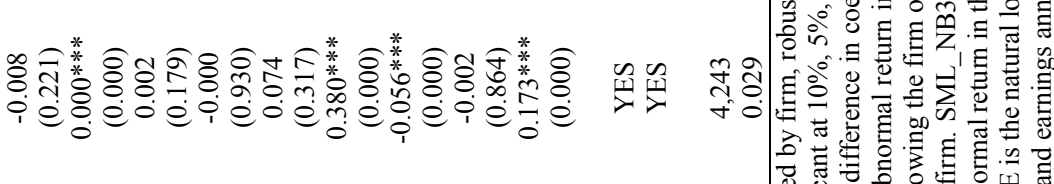

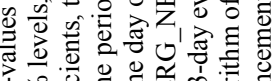

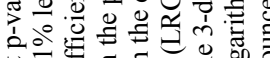

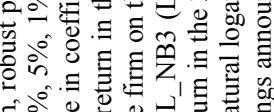

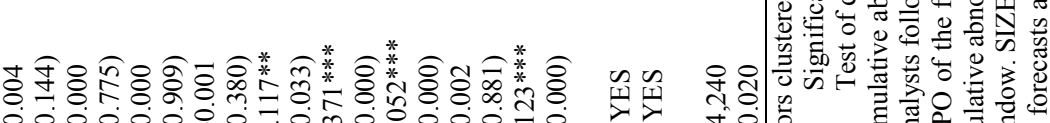

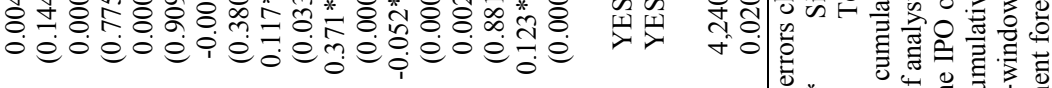

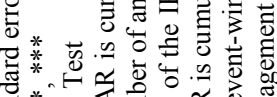

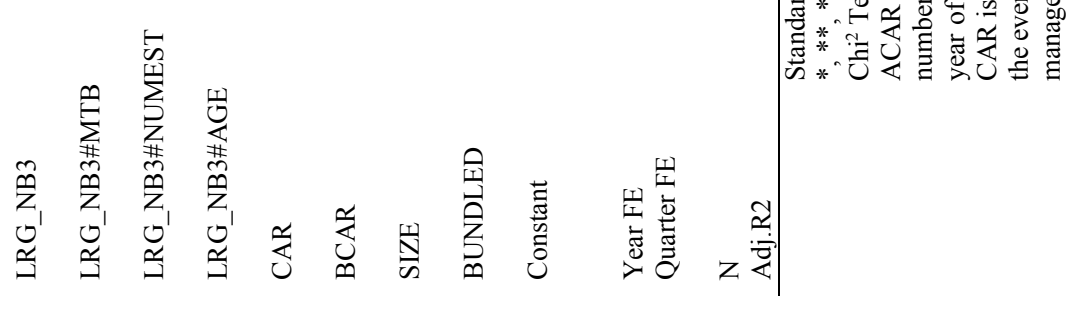




\section{CHAPTER 4 \\ The Profitability Effect of Small and Large Investors' Differential Trading around Management Forecasts}

The coefficients on the interaction terms of MTB and small and large investors' net-buy volume are all 0 , and mostly insignificant. The only consistently significant coefficient is that of large investors at the earnings announcement of forecasting firms. It implies that a higher market-to-book ratio causes large investors to trade more profitably on the earnings announcement of forecasting firms. As a result, there is a statistically significant difference between small and large investors' coefficient in the forecasting earnings announcement regressions, which in turn causes the effect of MTB on the difference in small and large investors' profitability to change from the earnings announcement to the management forecast. While at the earnings announcement large investors seem to have a slight profitability advantage trading in higher market-to-book firms, this advantage does not exist at the management forecast.

The coefficient on the interaction term of NUMEST with small investors' netbuy volume are negative but only significant at forecasting firms' earnings announcements. The coefficient on the interaction term with large investors' net-buy volume is positive and weakly significant at the earnings announcement of forecasting firms. The differences between small and large investors' coefficients are however significant at both the forecast and the earnings announcement of forecasting firms: higher analyst-following of forecasting firms disadvantages small investors and advantages large investors in terms of the profitability of their trades. Because there is no such profitability difference at the earnings announcement of non-forecasting firms but it appears at management forecasts, higher analyst-following increases the difference in profitability between small and large investors' trades, and creates a disadvantage for small investors at the management forecast.

The coefficients on the interaction terms of AGE and small and large investors' net-buy volume are mostly insignificant, the only exception is the significant negative coefficient of small investors in the management forecast regression in the 180-day period. While in that period large investors' coefficient is significantly lower at the forecast date compared to the earnings announcement of non-forecasting firms, this does not cause any differences in profitability of small and large investors between management forecasts and earnings announcements. 
In sum, the richness of the corporate information environment, as measured by MTB and NUMEST influences the profitability difference between small and large investors at the management forecast compared to the earnings announcement. However, while a higher market-to-book ratio helps small investors at the management forecast compared to the earnings announcement to a small degree, a higher number of analysts following the firm creates a profitability disadvantage for small investors' at management forecasts compared to earnings announcements. These findings partially support H3b.

\section{Management Forecast Characteristics}

Hypothesis 4 tests whether management forecasts that are easier to understand, decrease the profitability difference between small and large investors. Table 4.11 shows that the coefficients of the interaction terms of both HORIZON and SPEC with small investors' net-buy volume are positive and significant, and the coefficients of the interaction terms with large investors' net-buy volume are all negative and (weakly) significant. This results in the differences between small and large investors' profitability as a result of forecast characteristics to be significant. These results mean that management forecasts that have a shorter horizon and are more specific decrease small investors' trading profits and increase large investors' profits. The results imply that either small investors can take better advantage of uncertainty revealed in forecasts, or, which is more likely, large investors understand the significance of forecast characteristics better and can make better trading decisions based on them. 
Table 4.11 - Effect of Forecast Characteristics on Profitability of Small and Large

Investors' Trading at the Management Forecast and Earnings Announcement of

Forecasting Firms and at the Earnings Announcement of Non-Forecasting Firms

Profitability regressions of model (3), with interaction terms of SML_NB3, LRG_NB3, HORIZON, and SPEC, respectively:

$$
\begin{aligned}
\mathrm{ACAR}= & \beta_{0}+\beta_{1} \mathrm{SML}+\mathrm{NB} 3+\beta_{2} \mathrm{LRG}_{-} \mathrm{NB} 3+\beta_{3} \mathrm{CAR}+\beta_{4} \mathrm{BCAR} \\
& +\beta_{5} \mathrm{SIZE}+\beta_{6} \mathrm{BUNDLED}+\varepsilon
\end{aligned}
$$

\begin{tabular}{|c|c|c|c|}
\hline & $\begin{array}{c}\text { (1) } \\
\text { 90-days ACAR }\end{array}$ & $\begin{array}{c}\text { (2) } \\
\text { 180-days ACAR }\end{array}$ & $\begin{array}{c}\text { (3) } \\
\text { 360-days ACAR }\end{array}$ \\
\hline HORIZON & $\begin{array}{l}-0.000 \\
(0.320)\end{array}$ & $\begin{array}{l}-0.000 \\
(0.298)\end{array}$ & $\begin{array}{l}-0.000 \\
(0.498)\end{array}$ \\
\hline SPEC & $\begin{array}{c}0.017 \\
(0.137)\end{array}$ & $\begin{array}{c}0.026 \\
(0.157)\end{array}$ & $\begin{array}{l}0.053 * \\
(0.078)\end{array}$ \\
\hline SML_NB3 & $\begin{array}{l}-0.076^{*} \\
(0.084)\end{array}$ & $\begin{array}{c}-0.058 \\
(0.379)\end{array}$ & $\begin{array}{l}-0.159 \\
(0.122)\end{array}$ \\
\hline SML_NB3\#HORIZON & $\begin{array}{l}0.001^{*} \\
(0.094)\end{array}$ & $\begin{array}{l}0.001^{*} \\
(0.057)\end{array}$ & $\begin{array}{c}0.002 * * * \\
(0.001)\end{array}$ \\
\hline SML_NB3\#SPEC & $\begin{array}{l}0.069^{*} \\
(0.057)\end{array}$ & $\begin{array}{c}0.062 \\
(0.276)\end{array}$ & $\begin{array}{c}0.074 \\
(0.373)\end{array}$ \\
\hline LRG_NB3 & $\begin{array}{c}0.007 \\
(0.167)\end{array}$ & $\begin{array}{l}0.019 * * \\
(0.023)\end{array}$ & $\begin{array}{l}0.026 * * \\
(0.046)\end{array}$ \\
\hline LRG_NB3\#HORIZON & $\begin{array}{c}-0.000 \\
(0.504)\end{array}$ & $\begin{array}{c}-0.000 * * \\
(0.028)\end{array}$ & $\begin{array}{c}-0.000 \\
(0.218)\end{array}$ \\
\hline LRG_NB3\#SPEC & $\begin{array}{l}-0.005 \\
(0.340)\end{array}$ & $\begin{array}{l}-0.012 \\
(0.182)\end{array}$ & $\begin{array}{l}-0.018 \\
(0.174)\end{array}$ \\
\hline CAR & $\begin{array}{c}0.110^{* *} \\
(0.018)\end{array}$ & $\begin{array}{c}0.111 \\
(0.135)\end{array}$ & $\begin{array}{l}0.210^{*} \\
(0.072)\end{array}$ \\
\hline BCAR & $\begin{array}{c}0.389 * * * \\
(0.000)\end{array}$ & $\begin{array}{c}0.757 * * * \\
(0.000)\end{array}$ & $\begin{array}{c}1.428 * * * \\
(0.000)\end{array}$ \\
\hline SIZE & $\begin{array}{c}-0.023 * * * \\
(0.000)\end{array}$ & $\begin{array}{c}-0.042 * * * \\
(0.000)\end{array}$ & $\begin{array}{c}-0.077 * * * \\
(0.000)\end{array}$ \\
\hline BUNDLED & $\begin{array}{c}0.011 \\
(0.294)\end{array}$ & $\begin{array}{c}-0.003 \\
(0.846)\end{array}$ & $\begin{array}{l}-0.011 \\
(0.687)\end{array}$ \\
\hline Constant & $\begin{array}{c}0.297 * * * \\
(0.000)\end{array}$ & $\begin{array}{c}0.502 * * * \\
(0.000)\end{array}$ & $\begin{array}{c}0.842 * * * \\
(0.000)\end{array}$ \\
\hline $\begin{array}{l}\text { Year FE } \\
\text { Quarter FE }\end{array}$ & $\begin{array}{l}\text { YES } \\
\text { YES }\end{array}$ & $\begin{array}{l}\text { YES } \\
\text { YES }\end{array}$ & $\begin{array}{l}\text { YES } \\
\text { YES }\end{array}$ \\
\hline $\begin{array}{l}\mathrm{N} \\
\text { Adj.R2 }\end{array}$ & $\begin{array}{l}6,466 \\
0.051\end{array}$ & $\begin{array}{l}6,466 \\
0.065\end{array}$ & $\begin{array}{l}6,466 \\
0.096\end{array}$ \\
\hline
\end{tabular}

Standard errors clustered by firm, robust $\mathrm{p}$-values reported in parentheses.

$*, * *, * * *$ Significant at $10 \%, 5 \%, 1 \%$ levels, respectively, based on two-tailed tests.

$\mathrm{Chi}^{2}$ Test Test of difference in coefficients, two-tailed p-values reported in parentheses.

ACAR is cumulative abnormal return in the period following the event-window. HORIZON is length of forecast horizon, the number of days between the forecast date and the firm's fiscal year-end. SPEC is forecast precision, zero for point forecasts, one for range forecasts, and two for open-ended forecasts. SML_NB3 (LRG_NB3) is abnormal small (large) net-buy volume in the 3 -day event window $(-1$ to +1$)$ around an announcement. CAR is cumulative abnormal return in the 3 -day event window $(-1$ to +1$)$ around an announcement. BCAR is cumulative abnormal return in the 15 days preceding the event-window. SIZE is the natural logarithm of the market value 


\section{CHAPTER 4 \\ The Profitability Effect of Small and Large Investors' Differential Trading around Management Forecasts}

of equity five days prior to the announcement. BUNDLED is an indicator variable for bundled management forecasts and earnings announcements, 1 if announcement is bundled, 0 otherwise.

\subsection{Conclusion}

In this study we examine whether different investor classes benefit equally from management guidance. Specifically, we compare the economic consequences of small investors' trading decisions to those of large investors around management forecast announcements compared to earnings announcements.

We first examine whether the trading behavior of the two classes of investors are different at management forecasts compared to earnings announcements. We find that small investors initiate more buy and sell trades around management forecast announcements than large investors, but the net-buy volume of small and large investors is not different at the forecast date. When comparing the trading behavior of both small and large investors around the management forecast and the earnings announcement, we find that small investors trade proportionately more around earnings announcements, while large investors trade proportionately more around management forecasts. In sum, the trading behavior of small and large investors at the management forecast is different compared to that around the earnings announcement, and the difference in their trading behavior differs at the management forecast compared to earnings announcements.

Next, we test whether the trading behavior differential can be explained by differential trading on different forecast errors. We find that management forecasts influence the trading behavior of small and large investors differentially, because small investors trade in the direction of a random walk forecast error around the management forecast but not around earnings announcements, in contrast with large investors, whose trades are not associated with forecast errors around corporate announcements.

To address our main question of differential trading profitability of investor groups around management forecasts and earnings announcements, we examine whether the differential trading behavior of individual investors compared to large investors advantages or disadvantages them economically at the management forecast announcement compared to the earnings announcement. We find that the difference in 


\section{CHAPTER 4 \\ The Profitability Effect of Small and Large Investors' Differential Trading around Management Forecasts}

profitability between small and large investors' trades is different between earnings announcements and management forecasts. Specifically, small investors lose significantly more on trades around non-forecasting firms' earnings announcements, and they gain significantly more on trades around management forecasts. In sum, management forecasts improve the profitability difference of small investors' trades compared to earnings announcements by reversing a differential loss at the earnings announcement into a differential profit at the management forecast compared to large investors.

Additionally, we examine if firm characteristics or the characteristics of the management forecast affect the profitability differential of small investors' trades. We find that the proportion of intangible assets, the volatility of firms' operating income, and firm age do not influence the profitability difference between small and large investors at management forecast and earnings announcements. However, a higher market-to-book ratio increases the profitability differential of small investors' trades at the management forecast compared to the earnings announcement. Surprisingly, small investors' profitability advantage of trading in high-tech firms at the earnings announcement disappears at the management forecast, and similarly, a higher analyst following creates a profitability disadvantage for small investors at management forecasts compared to earnings announcements. Furthermore, large investors seem to take advantage of forecast characteristics to achieve better trading profitability compared to small investors. In sum, firm and forecast characteristics on average, do not help small investors to improve their profitability differential at management forecasts compared to earnings announcements.

Our study makes several contributions to literature. First, we contribute to the information asymmetry literature by examining the information asymmetry among investors directly, and, more importantly, we analyze the practical consequences thereof in terms of differential profitability of investor groups. Prior studies draw conclusions on information asymmetry among investors based on theory, the implicit assumptions of two groups of investors with differing sophistication, and the interpretation of trading volume information, an indirect measure. In consequence, based on such studies we do not know which investor groups contribute to higher trading volume, and therefore higher 


\section{CHAPTER 4 \\ The Profitability Effect of Small and Large Investors' Differential Trading around Management Forecasts}

information asymmetry, and to what extent. Rather than drawing indirect conclusions about the amount of small and large investors and their informedness, we examine directly the trading behavior of small and large investors. Furthermore, we are able to analyze the economic consequences of investor groups' differential trading at the public announcements of companies.

Second, our study contributes to the trading literature by documenting that there is a differential trading impact between small and large investors of management guidance compared to earnings announcements, with differential effects on small and large investors' profitability. Specifically, we show that small investors are likely to trade profitably at the management forecast and more profitably than large investors, while they trade unprofitably and more unprofitably than large investors at the earnings announcement. In sum, the comparative losses that small investors make around earnings announcements turn into comparative profitability around management forecasts.

Third, we contribute to the voluntary disclosure literature by examining the trading effects and the economic consequences thereof, of trading by small and large investors at the management forecast. We find that management forecasts induce differential trading compared to earnings announcements, as well as between small and large investors, turning small investors comparative losses at the earnings announcement into comparative profits around management forecasts. However, we also document that small investors are unable to take advantage of more precise management forecasts, unlike large investors who utilize this information in their trades to trade more profitably.

Our study has implications for regulators as well as investors. Our study promotes the SEC's understanding of small investors' use of financial information and trading behavior by providing information about the differential trading behavior of small investors induced by management forecasts. Using their behavior around earnings announcements as a benchmark, we show that small investors trade proportionately less around the management forecast than around earnings announcements. This is in contrast to large investors who trade proportionately more around management forecasts. These findings mean that management forecasts are used less by small investors for trading purposes. The reasons for lower trading on management forecasts by small investors 


\section{CHAPTER 4 \\ The Profitability Effect of Small and Large Investors' Differential Trading around Management Forecasts}

could either be due to lower accessibility or prominence of management forecasts (notwithstanding the efforts of regulators to make all financial information equally accessible to all investors), or the different characteristics of management forecasts that make them less understandable for small investors resulting in reduced motivation to trade. Our main finding however is that compared to comparatively higher losses of small investors at the earnings announcement, small investors achieve a higher comparative profit on their trades at the management forecast. This means that the lower proportion of small investors who trade on management forecast information achieve higher profitability than large investors, and are able to change trading losses around earnings announcements into profits. This finding implies that voluntary disclosures do not disadvantage small investors compared to large ones economically, on the contrary, they help small investors improve the profitability of their trades. On the negative side, our results suggest that firm or forecast characteristics do not help the trading profitability of small investors at the management forecasts, these seem to advantage large investors instead.

This study is also important from investors' perspective. We document that management forecasts make different contributions to trading profits of different investor classes, in comparison to earnings announcements. Specifically, while small investors trade with higher losses at the earnings announcement compared to large investors, they can take advantage of management forecasts to earn higher profits than large investors at the management forecast date.

Our study is subject to some limitations. Prior studies discuss the concern that using a trade-size classification rule to identify small and large investors is problematic due to large investors' incentives and practices to disguise their trades (e.g., Kyle, 1985; Campbell et al., 2009). While the robustness of our results to multiple cutoffs identifying small traders and our use of a high cutoff to identify large traders alleviate some of the specific concerns, our results should be interpreted with a caveat: we do not use a proprietary database with direct identification of small and large traders, but a public database of trades and rely on an algorithm for investor group identification. 

CHAPTER 5

Conclusion

5. Conclusion 


\section{CHAPTER 5}

Conclusion

\subsection{Summary}

The first study examines whether the possible earnings management of overoptimistic CEOs is recognized and included in the share price at the time the management forecast is issued, or whether investors react to the inferred (actual) earnings management at the announcement of realized earnings. In line with expectations the findings of the first study show that the market reacts more positively to the earnings announcements of overoptimistic CEOs in the small forecast error range compared to those of non-optimistic managers at the earnings announcement. These findings indicate that investors react negatively to the higher earnings management incentives of overoptimistic managers when the management forecast is issued and do not react to inferred earnings management of overoptimistic CEOs and/or react more positively to the inferred lack of earnings management by overoptimistic CEOs compared to non-optimistic managers when earnings are announced.

The second study examines the role voluntary management earnings forecasts play in the generation of information asymmetry among investors around public disclosures. First, the findings show that in isolation, voluntary management forecasts generate higher information asymmetry among investors than mandatory earnings announcements as evidenced by higher excess trading volume reactions associated with both pre-announcement and event-period private information at the management forecast date compared to the trading volume reaction of non-forecasting firms at the earnings announcement. This implies that the information asymmetry among investors is higher when the disclosure involves predictions for the future compared to disclosures that confirm past events. Second, earnings announcements of forecasting firms are associated with lower information asymmetry among investors than earnings announcements of nonforecasters since the excess trading volume reactions at the earnings announcement date associated with pre-announcement private information are lower, while those associated with event-period private information are not different across forecasters and nonforecasters. Finally, examining the aggregate trading volume effects of management forecasts from around the forecast issue and the subsequent earnings announcement, the 


\section{CHAPTER 5}

Conclusion

study concludes that investors of forecasting firms face a larger overall information asymmetry than investors of non-forecasting firms as a result of the event-period information component.

While the aggregate information asymmetry associated with pre-announcement information is not different between forecasting and non-forecasting firms, the aggregate information asymmetry associated with event-period information is higher for forecasters compared to non-forecasters. This implies that on average a management forecast generates the same level of disagreement among investors as an earnings announcement, and moreover, that, on average, management forecasts do not help in the processing of the subsequent earnings announcement.

The third study examines whether different investor classes benefit equally from management forecasts, by comparing the economic consequences of small investors' trading decisions to those of large investors around management forecast announcements compared to earnings announcements. First, results show that the trading behavior of small and large investors at the management forecast is different compared to that around the earnings announcement, and the difference in their trading behavior differs at the management forecast compared to earnings announcements. Furthermore, the trading behavior differential can be explained by differential trading on different forecast errors, because small investors trade in the direction of a random walk forecast error around the management forecast but not around earnings announcements, in contrast with large investors, whose trades are not associated with forecast errors around corporate announcements. Second, the trading behavior differential leads to differential profitability between small and large investors at the two announcements: management forecasts improve the profitability difference of small investors' trades compared to earnings announcements by reversing a differential loss at the earnings announcement into a differential profit at the management forecast compared to large investors. Third, firm and forecast characteristics on average, do not help small investors to improve their profitability differential at management forecasts compared to earnings announcements. 


\section{CHAPTER 5}

Conclusion

\subsection{Limitations}

The studies of this dissertation are subject to various limitations. In the second study I cannot fully rule out an alternative explanation of the findings that forecasting firms also have better quality financial statements. Therefore, the interpretation of the results depends on the extent to which the firm characteristics associated with the firm's forecasting choice (used in propensity score matching) also proxy for financial statement quality of the sample firms. Furthermore, in the sample selection I ensure that firm observations where forecasts and earnings announcements are issued on the same date are eliminated from my sample. While this enables me to separate and examine the incremental effect of management forecasts on trading volumes around public disclosures, if bundling firms are different from the unbundling and non-forecasting firms in my sample, my results may not be generalizable.

A limitation of the third study relates to the concern of using a trade-size classification rule to identify small and large investors. This identification may be problematic due to large investors' incentives and practices to disguise their trades (e.g., Kyle, 1985; Campbell et al., 2009). While the robustness of the results to multiple cutoffs identifying small traders and the use of a high cutoff to identify large traders alleviate some of the specific concerns, these results should be interpreted with a caveat: the study does not use a proprietary database with direct identification of small and large traders, but a public database of trades and relies on an algorithm for investor group identification.

\subsection{Contributions and Implications}

All three studies contribute to academic literature in a number of ways. The first study contributes to the literature on market reactions to public disclosures by showing that a managerial cognitive bias is an additional factor in explaining the market reaction to the issuance of management forecasts and the subsequent earnings announcement. Furthermore, the study contributes to the literature on cognitive biases by separating overoptimism from overconfidence in an empirical setting. Moreover, the study 


\section{CHAPTER 5}

Conclusion

contributes to the earnings management around thresholds literature by showing that the market is not fooled by the earnings management incentives presented by managers' own forecasts. And finally, while prior studies show that firms are punished for beating benchmarks at the earnings announcement date after 2001 (e.g., Keung et al., 2010), this study shows that the discounting depends on the extent to which the market already incorporated the incentives to manage earnings early on.

The results of the first study are important for two reasons. First, it is shown that investors are not fooled by overoptimistic forecasts, since the forecasts of overoptimistic managers are discounted by the market. By issuing higher management forecasts, firms managed by overoptimistic CEOs do not enjoy positive abnormal returns compared to firms of non-overoptimistic managers, at the forecast date. Second, it is also shown that after 2001 investor attitudes to earnings management are so negative that all firms managed by overoptimistic CEOs are punished with a lower share price as early as the management forecast date, i.e., the market reaction is driven by expectations of earnings management when the management forecast is issued rather than actual earnings management when earnings are announced.

The second study contributes to the trading volume literature by analyzing the excess trading volume effects of unbundled management forecasts and provides evidence on how an additional element of firms' disclosure policy affects information asymmetry among investors (Bamber et al., 2011). The study also contributes to the voluntary disclosure literature by investigating the effect of voluntary management earnings forecasts on the information asymmetry among investors. It shows that the overall effect of voluntary management forecasts on the information asymmetry among investors is negative, and contributes to increasing the informational disadvantage of some investors over others, potentially also weakening the disclosure's positive effects on the firm's cost of capital. The managerial implications of the results are that an attempt at improving the information environment of the firm by issuing voluntary management forecasts may have unintended consequences. This is because more publicly available information about a firm decreases the information asymmetry between the firm and its investors and decreases the firm's cost of capital. However, these results show that increased disclosure 


\section{CHAPTER 5}

Conclusion

in the form of management forecasts may increase the information asymmetry among the investors of the firm, potentially reducing the positive effects on the cost of capital achieved through a richer information environment. The implications of these findings for investors are as follows. The earnings information contained in the forecast renders private information search less useful subsequent to the forecast: private information search is more profitable prior to the forecast because the information asymmetry among investors is higher, but less profitable following the forecast because the forecast reduces the information asymmetry among investors. The regulatory implications of the findings are that equal access to management forecasts may not translate into equal informedness, and may not completely resolve the information asymmetry between more and less informed investors.

The third study contributes to the information asymmetry literature by examining the information asymmetry among investors directly, using the trading behavior of small and large investors. More importantly the study contributes by analyzing the economic consequences of investor groups' differential trading at the public announcements of companies in terms of the differential profitability of investor groups. The study also contributes to the trading literature by documenting that there is a differential trading impact between small and large investors of management guidance compared to earnings announcements, with differential effects on small and large investors' profitability. Moreover, the study contributes to the voluntary disclosure literature by examining the trading effects and the economic consequences of trading by small and large investors at the management forecast date. Results show that management forecasts turn small investors comparative losses at the earnings announcement into comparative profits around management forecasts. The study promotes the regulator's understanding of small investors' use of financial information and trading behavior by providing information about the differential trading behavior of small investors induced by management forecasts. The findings show that while management forecasts are used less by small investors for trading purposes, they do not disadvantage small investors compared to large ones economically, on the contrary, they help small investors to trade profitably at the management forecast. The results of the third study are also useful for 


\section{CHAPTER 5}

\section{Conclusion}

investors: while small investors trade with higher losses at the earnings announcement compared to large investors, they can take advantage of management forecasts to earn higher profits than large investors at the management forecast date. 
CHAPTER 5

Conclusion 
References

\section{References}




\section{References}

Ahmed, A. and R. Schneible, 2007, The impact of Regulation Fair Disclosure on investors' prior information quality: Evidence from an analysis of changes in trading volume and stock price reactions to earnings announcements, Journal of Corporate Finance, 13(2/3):282-99

Ahmed, A., R. Schneible, D. Stevens, 2003, An empirical analysis of the effects of online trading on stock price and trading volume reactions to earnings announcements, Contemporary Accounting Research, 20(3):413-39

Ajinkya, B.B., S. Bhojraj, P. Sengupta, 2005, The association between outside directors, institutional investors and the properties of management earnings forecasts, Journal of Accounting Research, 43(3):343-376

Ajinkya, B.B., and M.J. Gift, 1984, Corporate managers' earnings forecasts and symmetrical adjustments of market expectations, Journal of Accounting Research, 22(2):425-444

American Institute of Certified Public Accountants, AICPA, 1973, Report of the Study Group on Objectives of Financial Statements, New York, NY:AICPA

Anilowski, C., M. Feng, D.J. Skinner, 2007, Does earnings guidance affect market returns? The nature and information content of aggregate earnings guidance, Journal of Accounting and Economics, 44(1-2):36-63

Armstrong, C.S., A.D. Jagolinzer, D.F. Larcker, 2010, Chief Executive Officer Equity Incentives and Accounting Irregularities, Journal of Accounting Research, 48(2):225-271

Asthana, S., S. Balsam, S. Sankaraguruswamy, 2004, Differential response of small versus large investors to $10-\mathrm{K}$ filings on EDGAR, Accounting Review, 79(3):571-589

Atiase, R.K. and L.S. Bamber, 1994, Trading volume reactions to annual accounting earnings announcements, Journal of Accounting \& Economics, 17(3):309-329 


\section{References}

Baginski, S.P., E.J., Conrad, J.M. Hassell, 1993, The effects of management forecast precision on equity pricing and on the assessment of earnings uncertainty, Accounting Review, 68(4):913-927

Baginski, S.P.,and J.M. Hassell, 1990, The market interpretation of management earnings forecasts as a predictor of subsequent financial analyst forecast revision, Accounting Review, 65(1):175-190

Baginski, S.P. and J.M. Hassell, 1997, Determinants of management forecast precision, Accounting Review, 72(2):303-312

Baginski, S.P., J.M. Hassell, M.D. Kimbrough, 2004, Why do managers explain their earnings forecasts?, Journal of Accounting Research, 42(1):1-29

Ball, R.,and L. Shivakumar, 2008, How much new information is there in earnings?, Journal of Accounting Research, 46(5):975-1016

Bamber, L., 1986, The information content of annual earnings releases: A trading volume approach, Journal of Accounting Research, 24(1):40-56

Bamber, L., 1987, Unexpected earnings, firm size, and trading volume around quarterly earnings announcements, Accounting Review, 62(3):510-32

Bamber, L.S., O.E. Barron, D.E. Stevens, 2011, Trading Volume Around Earnings Announcements and Other Financial Reports: Theory, Research Design, Empirical Evidence, and Directions for Future Research, Contemporary Accounting Research, 28(2):431-471

Bamber, L., O. Barron, T. Stober, 1997, Trading volume and different aspects of disagreement coincident with earnings announcements, Accounting Review, 72(4):575-97

Bamber, L., O. Barron, T. Stober, 1999, Differential interpretations and trading volume, Journal of Financial and Quantitative Analysis, 34(3):369-86 


\section{References}

Bamber, L.S. and Y.S. Cheon, 1998, Discretionary management earnings forecast disclosures: Antecedents and outcomes associated with forecast venue and specificity choices, Journal of Accounting Research, 36(2):167-190

Bamber, L., J. Jiang, I. Wang, 2010, What's my style? The influence of top managers on voluntary corporate disclosure, Accounting Review, 85(4):1131-1162

Barber, B.M. and T. Odean, 2002, Online Investors: Do the Slow Die First?, Review of Financial Studies, 15(2):455-487

Barron, O., D. Byard, O. Kim, 2002, Changes in analysts' information around earnings announcements, Accounting Review, 11(4):821-46

Barron, O., D. Byard, Y. Yu, 2010, Earnings announcement disclosures that spur differential interpretations, Working paper, Pennsylvania State University

Barron, O., D. Harris, M. Stanford, 2005, Evidence that investors trade on private eventperiod information around earnings announcements, Accounting Review, $80(2): 403-21$

Barth, M., R. Kasznik, M. McNichols, 2001, Analyst coverage and intangible assets, Journal of Accounting Research, 39(1):1-34

Bartov, E., D. Givoly, C. Hayn, 2002, The rewards to meeting or beating earnings expectations, Journal of Accounting and Economics, 33:173-204

Bartov, E., S. Radhakrishnan, I. Krinsky, 2000, Investor sophistication and patterns in stock returns after earnings announcements, Accounting Review, 75(1):43-63

Basu, S., 1997, The conservatism principle and the asymmetric timeliness of earnings, Journal of Accounting and Economics, 24(1):3-37

Beatty, R.P. and J.R.M. Hand, 1992, The Causes and Effects of Mandated Accounting Standards: SFAS No. 94 as a Test of the Level Playing Field Theory, Journal of Accounting, Auditing \& Finance, 7(4):509-530 


\section{References}

Beaver, W., 1968, The information content of annual earnings announcements, Journal of Accounting Research, 6:67-92

Beaver, W., 1998, Financial reporting: an accounting revolution, Prentice-Hall, Englewood Cliffs, NJ

Ben-David, I., J.R. Graham, C.R. Harvey, 2013, Managerial Miscalibration, Quarterly Journal of Economics, 128(4):1547-1584

Bernard, V., and J. Thomas, 1989, Post-earnings-announcement drift: Delayed price response or risk premium?, Journal of Accounting Research, 27(supplement):136

Bernard, V., and J. Thomas, 1990, Evidence that stock prices do not fully reflect the implications of current earnings for future earnings, Journal of Accounting and Economics, 13(4):305-340

Beyer, A., D.A. Cohen, T.Z. Lys, B.R. Walther, 2010, The financial reporting environment: Review of the recent literature, Journal of Accounting and Economics, 50:296-343

Bhattacharya, N., 2001, Investors' trade size and trading responses around earnings announcements: An empirical investigation, Accounting Review, 76(2):221-44

Bhattacharya, N., E. Black, T. Christensen, R. Mergenthaler, 2007, Who trades on pro forma earnings information?, Accounting Review, 82(3):581-619

Billett, M.T. and Y. Qian, 2008, Are Overconfident CEOs Born or Made? Evidence of Self-Attribution Bias from Frequent Acquirers, Management Science, 54(6):1037-1051

Botosan, C., 1997, Disclosure Level and the Cost of Equity Capital, Accounting Review, 72:323-349

Botosan, C.A. and M.A. Plumlee, 2002, A re-examination of disclosure level and the expected cost of equity capital, Journal of Accounting Research, 40(1):21-40 


\section{References}

Botosan, C.A., M.A. Plumlee, Y. Xie, 2004, The role of information precision in determining the cost of equity capital, Review of Accounting Studies, 9:233-59

Burgstahler, D. and I. Dichev, 1997, Earnings Management to Avoid Earnings Decreases and Losses, Journal of Accounting and Economics, 24:99-126

Bushee, B., D. Matsumoto, G. Miller, 2003, Open versus closed conference calls: the determinants and effects of broadening access to disclosure, Journal of Accounting and Economics, 34:149-180

Camerer, C. and D. Lovallo, 1999, Overconfidence and Excess Entry: An Experimental Approach, American Economic Review, 89(1):306-318

Camerer, C.F. and U. Malmendier, 2007, Behavioral Economics of Organizations, in: Diamond, P. and H. Vartianen (eds.), Behavioral Economics and Its Applications, Princeton University Press, Princeton and Oxford, pp235-281

Campbell, T.C., M. Gallmeyer, S.A. Johnson, J. Rutherford, B.W. Stanley, 2011, CEO Optimism and Forced Turnover, Journal of Financial Economics, 101(3):695712

Campbell, J., T. Ramadorai, A. Schwartz, 2009, Caught on tape: institutional trading, stock returns, and earnings announcements, Journal of Financial Economics, 92:66-91

Carver, C.S., M.F. Scheier, S.C. Segerstrom, 2010, Optimism, Clinical Psychology Review, 30:879-889

CFA Institute, 2006, Breaking the short-term cycle, http://www.cfapubs.org/doi/pdf/10.2469/ccb.v2006.n1.4194

Cho, M. and S.Y. Kwon, 2014, Trading Volume and Investor Disagreement Around Management Forecast Disclosures, Journal of Accounting, Auditing \& Finance, 29(1):3-30 


\section{References}

Choi, J.H. and D.A. Ziebart, 2004, Management earnings forecasts and the market's reaction to predicted bias in the forecast, Asia-Pacific Journal of Accounting and Economics, 11 (2):167-192

Choi, J.H., L.A. Myers, Y. Zang, D.A. Ziebart, 2010, The roles that forecast surprise and forecast error play in determining management forecast precision, Accounting Horizons, 24(2):165-188

Coller, M. and T.L. Yohn, 1997, Management forecasts and information asymmetry: An examination of bid-ask spreads, Journal of Accounting Research, 35(2):181-191

Collins, D.W. and S.P. Kothari, 1989, An analysis of intertemporal and cross-sectional determinants of earnings response coefficients, Journal of Accounting and Economics, 11(2-3):143-181

Cready, W.M., 1988, Information value and investor wealth: The case of earnings announcements, Journal of Accounting Research, 26(Spring):1-27

Cready, W.M. and P.G. Mynatt, 1991, The information content of annual reports: A price and trading response analysis, Accounting Review, (April):291-312

Cuijpers, R. and E. Peek, 2010, Reporting Frequency, Information Precision and Private Information Acquisition, Journal of Business Finance \& Accounting, $37(1) \&(2): 27-59$

Deaves, R., C. Dine, W. Horton, 2006, How are Investment Decisions Made?, Working Paper, Task Force to Modernize Securities Legislation in Canada

Degeorge, F., J. Patel, R. Zeckhauser, 1999, Earnings Management to Exceed Thresholds, Journal of Business, 72:1-33

Diamond, D.W. and R.E. Verrecchia, 1991, Disclosure, liquidity, and the cost of capital, Journal of Finance, 46:1325-1359

Dye, R.A., 2001, An evaluation of "essays on disclosure" and the disclosure literature in accounting, Journal of Accounting and Economics, 32:181-235 


\section{References}

Easton, P. and M.E. Zmijewski, 1989, Cross-sectional Variation in the Stock Market Response to Accounting Earnings Announcements, Journal of Accounting and Economics, 11(2-3):117-141

Ellis, K., R. Michaely, M. O’Hara, 2000, The accuracy of trade classification rules: Evidence from Nasdaq, Journal of Financial and Quantitative Analysis, 34:529551

Fama, E.F. and K.R. French, 1997, Industry costs of equity, Journal of Financial Economics, 43(2):153-193

Foster, G., 1986, Financial Statement Analysis, 2nd edition, Englewood Cliffs, NJ: Prentice Hall

Fuller, J. and M. Jensen, 2002, Just say no to wall street, Journal of Applied Corporate Finance, 14:41-46

Gelb, D. and P. Zarowin, 2000, Corporate disclosure policy and the informativeness of stock prices, Working Paper, New York University, New York, NY

Grossman, S.J., 1981, The role of warranties and private disclosure about product quality, Journal of Law and Economics, 24:461-483

Grossman, S.J. and O.D. Hart, 1980, Disclosure laws and takeover bids, Journal of Finance, 35:323-334

Hand, J.R. and R.P. Beatty, 1992, The causes and effects of mandated accounting standards: SFAS No. 94 as a test of the level playing field theory, Journal of Accounting, Auditing and Finance, 7(Fall):509-530

Hayn, C., 1995, The information content of losses, Journal of Accounting and Economics, 20(2):125-153

Healy, P., A. Hutton, K. Palepu, 1999, Stock performance and intermediation changes surrounding sustained increases in disclosure, Contemporary Accounting Research, 16:485-520 


\section{References}

Healy, P.M. and K.G. Palepu, 1993, The Effect of Firms' Financial Disclosure Strategies on Stock Prices, Accounting Horizons, 7(1):1-11

Healy, P.M. and K.G. Palepu, 2001, Information asymmetry, corporate disclosure, and the capital markets: A review of the empirical disclosure literature, Journal of Accounting and Economics, 31:405-440

Heaton, J., 2002, Managerial Optimism and Corporate Finance, Financial Management, 31: $33-45$

Hilary, G. and C. Hsu, 2011, Endogenous overconfidence in managerial forecasts, Journal of Accounting and Economics, 51:300-313

Hirshleifer, D., J. Myers, L. Myers, S. Teoh, 2008, Do individual investors cause postearnings announcement drift? Direct evidence from personal trades, Accounting Review, 83(6):1521-1550

Hirst, D.E., L. Koonce, J. Miller, 1999, The joint effect of management's prior forecast accuracy and the form of its financial forecasts on investor judgment, Journal of Accounting Research, 37(Supplement):101-124

Hirst, E., L. Koonce, S. Venkataraman, 2008, Management earnings forecasts: A review and framework, Accounting Horizons, 22(3):1-24

Holthausen, R. and R. Verrecchia, 1990, The effect of informedness and consensus on price and volume behavior, Accounting Review, 65(1):191-208

Houston, J., B. Lev, J. Tucker, 2010, To guide or not to guide? Causes and consequences of stopping quarterly earnings guidance, Contemporary Accounting Research, 27:143-185

Hribar, P. and H. Yang, 2013, CEO Overconfidence and Management Forecasting, Working Paper, University of Iowa and University of Pennsylvania 


\section{References}

Hsieh, P., T. Koller, D.R. Rajan, 2006, The misguided practice of earnings guidance, McKinsey Quarterly, http://www.mckinseyquarterly.com/The_misguided_practice_of_earnings_gui dance 1759

Hutton, A.P., G.S. Miller, D J. Skinner, 2003, The role of supplementary statements with management earnings forecasts, Journal of Accounting Research, 41(5):867890

Hutton, A.P. and P. C. Stocken, 2007, Effect of reputation on the credibility of management forecasts, Working paper, Boston College and Dartmouth College

Jennings, R., 1987, Unsystematic security price movements, management earnings forecasts, and revisions in consensus analyst earnings forecasts, Journal of Accounting Research, 25(1):90-110

Jensen, M., K. Murphy, E. Wruck, 2004, Remuneration: Where we've been, how we got to here, what are the problems, and how to fix them, Working paper, Harvard Business School

Kahneman, D. and D. Lovallo, 1993, Timid Choices and Bold Forecasts: A Cognitive Perspective on Risk Taking, Management Science, 39(1):17-31

Kanodia, C., 2007, Accounting Disclosure and Real Effects, Foundations and trends in accounting, Now Publishers Inc.

Karpoff, J., 1986, A theory of trading volume, Journal of Finance, 41(5):1069-87

Kasznik, R., 1999, On the association between voluntary disclosure and earnings management, Journal of Accounting Research, 37:57-81

Kasznik, R. and M. McNichols, 2002, Does meeting earnings expectations matter? Evidence from analyst forecast revisions and share prices, Journal of Accounting Research, 40:727-759 


\section{References}

Ke, B., and S. Ramalingegowda, 2005, Do institutional investors exploit the postearnings-announcement drift?, Journal of Accounting and Economics, 39(1):2553

Keung, E., Z. Xinglin, M. Shih, 2010, Does the Stock Market See a Zero or Small Positive Earnings Surprise as a Red Flag?, Journal of Accounting Research, 48(1):105135

Kile, C., G. Pownall, G. Waymire, 1998, How frequently do managers disclose prospective earnings information?, Journal of Financial Statement Analysis, $3: 5-16$

Kim, O. and R. Verrecchia, 1991a, Trading volume and price reactions to public announcements, Journal of Accounting Research, 29(2):302-21

Kim, O. and R. Verrecchia, 1991b, Market reaction to anticipated announcements, Journal of Financial Economics, 30(2):273-309

Kim, O. and R. Verrecchia, 1994, Market liquidity and volume around earnings announcements, Journal of Accounting and Economics, 17(1):41-67

Kim, O. and R. Verrecchia, 1997, Pre-announcement and event-period private information, Journal of Accounting and Economics, 24(3): 95-419

King, T., 2013, Earnings Guidance is Alive and Well, Financial Executive, 29(2):19-20

Krehmeyer, D. and M. Orsagh, 2006, Breaking the short-term cycle: Discussion and recommendations on how corporate leaders, asset managers, investors, and analysts can refocus on long-term value. Proceedings of the CFA Center for Financial Market Integrity and Business Roundtable Institute for Corporate Ethics symposium series on short-termism

Kyle, A.,1985, Continuous auctions and insider trading, Econometrica, 53:1315-1335

Lang, M. and R. Lundholm, 1996, Corporate disclosure policy and analyst behavior, Accounting Review, 71:467-492 


\section{References}

Lawrence, A., 2013, Individual investors and financial disclosure, Journal of Accounting and Economics, 56:130-147

Lawrence, A., M. Minutti-Meza, P. Zhang, 2011, Can Big 4 versus Non-Big 4 Differences in Audit-Quality Proxies Be Attributed to Client Characteristics?, Accounting Review, 86(1):259-286

Lee, C.M.C., 1992, Earnings news and small traders: An intraday analysis, Journal of Accounting and Economics (June/September): 265-302

Lee, C.M.C. and B. Radhakrishna, 2000, Inferring investor behavior: Evidence from TORQ data, Journal of Financial Markets, 3:83-111

Lee, C.M.C. and M.J. Ready, 1991, Inferring trade direction from intraday data, Journal of Finance, (June):733-746

Leuz, C. and R. Verrecchia, 2000, The Economic Consequences of Increased Disclosure, Journal of Accounting Research, 38:91-124

Leuz, C. and P. Wysocki, 2008, Economic Consequences of Financial Reporting and Disclosure Regulation: A Review and Suggestions for Future Research, University of Chicago and Massachusetts Institute of Technology Working Paper

Lev, B. and P. Zarowin, 1999, The boundaries of financial reporting and how to extend them, Journal of Accounting Research, 37(2):353-386

Levitt, A., 1997, Corporate finance in the information age, Remarks delivered to the Securities Regulation Institute, San Diego, California, January 23, http://www.sec.gov/news/speech/speecharchive/1997/spch135.txt

Levitt, A., 1998a, A question of integrity: Promoting investor confidence by fighting insider trading, Speech given at the SEC Speaks Conference, February 27

Levitt, A., 1998b, The numbers game, Speech given at NYU Center for Law and Business, September 28 


\section{References}

Levitt, A., 1998c, The Importance of High Quality Accounting Standards, Accounting Horizons, 12(1):79-82

Levitt, A., 1999, Quality information: The lifeblood of our markets, Speech given at the Economic Club of New York, October 18

Li, F., M. Minnis, V. Nagar, M. Rajan, 2010, Formal and real authority in organizations: An empirical assessment, Working Paper, University of Michigan

Malmendier, U. and G. Tate, 2005, CEO Overconfidence and Corporate Investment, Journal of Finance, 60:2661-2700

Malmendier, U. and G. Tate, 2008, Who makes acquisitions? CEO overconfidence and the market's reaction, Journal of Financial Economics, 89:20-43

Malmendier, U. and D. Shantikumar, 2007, Are Small Investors Naive about Incentives?, Journal of Financial Economics, 85(2):457-89

Mikhail, M.B., B.R. Walther, R.H. Willis, 2007, When Security Analysts Talk, Who Listens?, Accounting Review, 82(5):1227-1253

Milgrom, P., 1981, Good news and bad news: representation theorems and applications, Bell Journal of Economics, 12:380-391

Miller, B., 2010, The effects of reporting complexity on small and large investor trading, Accounting Review, 85:2107-2144

Morse, D., 1980, Asymmetrical information in securities markets and trading volume, Journal of Financial and Quantitative Analysis, 15(5):1129-48

National Investor Relations Institute (NIRI), 2006, NIRI Issues 2006 Survey Results on Earnings Guidance Practices, Vienna, VA:NIRI, in: Hirst, D.E., L. Koonce, and S. Venkataraman, 2008, Management Earnings Forecasts: A Review and Framework, Accounting Horizons, 22(3):315-338

Ng, J., I. Tuna, R. Verdi, 2006, Management forecasts, disclosure quality, and market efficiency, Working paper, The Wharton School, University of Pennsylvania 


\section{References}

Ng, J., I. Tuna, R. Verdi, 2013, Management forecast credibility and underreaction to news, Review of Accounting Studies, 18(4):956-986

Nichols, D., J. Tsay, P. Larkin, 1979, Investor trading responses to differing characteristics of voluntarily disclosed earnings forecasts, Accounting Review, $54(2): 376-82$

NYSE, 2000, Shareownership 2000, http://www1.nyse.com/pdfs/shareho.pdf

Oyer, P., 1998, Fiscal year ends and nonlinear incentive contracts: The effect on business seasonality, Quarterly Journal of Economics, 113(1):149-185

Patell, J.M., 1976, Corporate forecasts of earnings per share and stock price behavior: Empirical tests, Journal of Accounting Research, 14(2):246-276

Penman, S.H., 1980, An empirical investigation of the voluntary disclosure of corporate earnings forecasts, Journal of Accounting Research, 18(1):132-160

Pownall, G., C. Wasley, G. Waymire, 1993, The stock price effects of alternative types of management earnings forecasts, Accounting Review, 68(4):896-912

Rogers, J.L. and P.C. Stocken, 2005, Credibility of management forecasts, Accounting Review, 80(4):1233-1260

Rogers, J.L. and A. Van Buskirk, 2013, Bundled forecasts in empirical accounting research, Journal of Accounting and Economics, 55:43-65

Roll, R., 1986, The hubris hypothesis of corporate takeovers, Journal of Business, 59(2):197-217

Rosenbaum, P.R. and D.B. Rubin, 1983, The Central Role of the Propensity Score in Observational Studies for Causal Effects, Biometrika, 70(1):41-55

Schrand, C. and S. Zechman, 2012, Executive overconfidence and the slippery slope to financial misreporting, Journal of Accounting and Economics, 53(1/2):311-329 


\section{References}

SEC, Securities and Exchange Commission, 2000, Final Rule: Selective Disclosure and Insider Trading, Release Nos. 33-7881, 34-43154, http://www.sec.gov/rules/final/33-7881.htm

SEC, Securities and Exchange Commission, 2009, Announcement From the SEC Investor Advisory Committee, SEC Press Release 2009-175, Washington, D.C., July 29, 2009, http://www.sec.gov/news/press/2009/2009-175.htm

SEC, Securities and Exchange Commission, 2012, SEC Issues Financial Literacy Study Mandated by the Dodd-Frank Act, SEC Press Release 2012-172, Washington, D.C., Aug. 30, 2012, http://www.sec.gov/News/PressRelease/Detail/PressRelease/1365171484290

SEC, Securities and Exchange Commission, 2013, The Investor's Advocate: How the SEC Protects Investors, Maintains Market Integrity, and Facilitates Capital Formation, http://www.sec.gov/about/whatwedo.shtml

Simon, H.A., 1955, A Behavioral Model of Rational Choice, Quarterly Journal of Economics, 69(1):99-118

Skinner, D.J., 1994, Why firms voluntarily disclose bad news, Journal of Accounting Research, 32(1):38-60

Skinner, D.J. and R.G. Sloan, 2002, Earnings surprises, growth expectations, and stock returns, or, don't let an earnings torpedo sink your portfolio, Review of Accounting Studies, 7:289-312

Statman, M. and J.F. Sepe, 1989, Project Termination Announcements and the Market Value of the Firm, Financial Management, 18(4):74-81

Trueman, B., 1986, Why do managers voluntarily release earnings forecasts?, Journal of Accounting and Economics, 8:53-72

Tasker, S., 1998, Bridging the information gap: quarterly conference calls as a medium for voluntary disclosure, Review of Accounting Studies, 3(1\&2):137-167 


\section{References}

U.S. Chamber of Commerce, 2007, Commission on the regulation of U.S. capital markets in the 21st century: Report and recommendations, http://www.uschamber.com/publications/reports/0703capmarketscomm.htm

U.S. Congress, 1995, Private Securities Litigation Reform Act of 1995, http://www.gpo.gov/fdsys/pkg/PLAW-104publ67/html/PLAW-104publ67.htm

Utama, S. and W.M. Cready, 1997, Institutional ownership, differential predisclosure precision and trading volume at announcement dates, Journal of accounting \& economics, 24(2):129-150

Verrecchia, R., 2001, Essays on disclosure, Journal of Accounting and Economics, $32: 97-180$

Waymire, G., 1984, Additional evidence on the information content of management earnings forecasts, Journal of Accounting Research, 22(2):703-718

White, M.J., 2014, Protecting the Retail Investor, Speech by the SEC Chair at the Consumer Federation of America, Consumer Assembly, March 21, http://www.sec.gov/News/Speech/Detail/Speech/1370541226174\#.U$\underline{\text { YkWWMdjj4 }}$

Williams, P.A., 1996, The relation between a prior earnings forecast by management and analyst response to a current management forecast, Accounting Review, 71(1):103-113 




\section{Curriculum Vitae}

\section{Curriculum Vitae}

Réka Felleg holds a Master of Science degree in Strategic Finance from the Oxford Brookes University, UK. She is also a fellow of the Association of Chartered and Certified Accountants (ACCA). In September 2009, she joined the $\mathrm{PhD}$ program in Accounting at Maastricht University. As of September 2014, Réka is an Associate

Professor at the Accounting Section, Amsterdam Business School, University of Amsterdam. 